ZENTRUM FÜR BIODIVERSITÄT UND NACHHALTIGE LANDNUTZUNG

SEKTION BIODIVERSITÄT, ÖKOLOGIE UND NATURSCHUTZ

CENTRE OF BIODIVERSITY AND SUSTAINABLE LAND USE

SECTION: BIODIVERSITY, ECOLOGY AND NATURE CONSERVATION

\title{
Root system structure and functions across coastal saltmarsh flooding gradients
}

\author{
Dissertation \\ zur Erlangung des mathematisch-naturwissenschaftlichen Doktorgrades \\ „Doctor rerum naturalium“ \\ der Georg-August-Universität Göttingen \\ im Promotionsprogramm Biologische Diversität und Ökologie \\ der Georg-August University School of Science (GAUSS)
}

vorgelegt von

\author{
Regine Redelstein \\ aus Augsburg
}

Göttingen, Dezember 2017 



\section{Betreuungsausschuss}

Prof. Dr. Christoph Leuschner,

Abteilung Pflanzenökologie und Ökosystemforschung, Universität Göttingen

Prof. Dr. Alexander Knohl,

Abteilung Bioklimatologie, Universität Göttingen

Prof. Dr. Gerhard Zotz,

Abteilung Funktionelle Ökologie, Universität Oldenburg

\section{$\underline{\text { Mitglieder der Prüfungskommission }}$}

Referent: Prof. Dr. Christoph Leuschner, Abteilung Pflanzenökologie und Ökosystemforschung, Universität Göttingen

Korreferent: Prof. Dr. Gerhard Zotz,

Abteilung Funktionelle Ökologie, Universität Oldenburg

\section{$\underline{\text { Weitere Mitglieder der Prüfungskommission }}$}

Prof. Dr. Hermann Behling,

Abteilung Palynologie und Klimadynamik, Universität Göttingen

Prof. Dr. Dirk Hölscher, Abteilung Waldbau und Waldökologie der Tropen, Universität Göttingen

Prof. Dr. Alexander Knohl,

Abteilung Bioklimatologie, Universität Göttingen

Prof. Dr. Holger Kreft,

Abteilung Biodiversität, Makroökologie und Biogeographie, Universität Göttingen

Tag der mündlichen Prüfung: 08.02.2018 



\section{Summary}

Salt marshes are ecosystems with extreme environmental conditions such as regular tidal inundation, mechanical disturbances, salinity, waterlogged and anoxic soils, and potentially toxic compounds in the soil. This adverse abiotic environment requires a high degree of adaptation of inhabiting plants and animals and results in a highly specialized community in this ecosystem. The gradual elevation from sea level from the lowermost pioneer zone, where the establishment of salt marshes begins, to the upper salt marsh is characterized by a gradient of these abiotic factors leading to a distinct zonation of salt marsh communities.

The presented $\mathrm{PhD}$ thesis is part of the joint research project BEFmate (Biodiversity and Ecosystem Functioning across marine and terrestrial ecosystems) with the aim to study BEF relations during the succession from marine (tidal flat) to semi-terrestrial (salt marsh) ecosystems. As part of this project, the thesis investigated different root system functions and their relation to the abiotic conditions across the salt marsh flooding gradient. It thereby contributes to the understanding of ecological processes involved in the development of salt marsh zonation as well as their sensitivity to environmental change. To fulfill these objectives, the study included in situ investigations at two natural salt marsh sites on the German North Sea coast, investigations of communities transplanted to experimental islands, as well as an additional greenhouse experiment.

Under the controlled conditions of a greenhouse experiment, we investigated effects of waterlogged sediments on seedlings of three saltmarsh species characteristic for the three zones in NW European salt marshes (Salicornia europaea from the pioneer zone, Atriplex portulacoides from the lower salt marsh, Elytrigia atherica from the upper salt marsh). Seedlings of these species were grown under different sediment waterlogging treatments within mesocosms simulating tidal inundation and subsequently subjected to an erosion treatment. The upper marsh species $E$. atherica showed fastest root and shoot growth under drained conditions but suffered strongest in the waterlogged sediment compared to A. portulacoides and S. europaea from the lower salt marsh and pioneer zone, respectively. Resistance against erosion decreased in all three species from drained to completely waterlogged soil conditions with the strongest negative impact of waterlogging on the otherwise strongly competitive species E. atherica. We found that resistance towards erosion was strongly influenced by root growth of the seedlings. This indicates that species-specific responses of root growth of seedlings under waterlogged soil conditions may be a first determinant of the distribution of species across the saltmarsh elevational and flooding gradient.

In our second study we conducted an inventory of fine root mass across the saltmarsh gradient and across two geomorphologically different sites. Fine root biomass was dependent on soil texture and 
plant-available nutrient concentrations in soil: we found higher fine root biomass at the sandy (and nutrient poorer) site on the back-barrier island of Spiekeroog compared to the clayey mainland salt marsh near Westerhever. According to the optimal resource partitioning theory, fewer nutrients in the soil require increased investments in fine root growth for nutrient uptake. Furthermore, the more erosion-prone sandy sediment may require increased root biomass for plant stability under mechanical disturbances. However, the most important predictor variable for fine root biomass was species diversity. At both sites, fine root mass was greatest in communities with highest plant species richness (in the intermediate lower salt marsh), potentially caused by root space partitioning in this community. With this study we could demonstrate that salt marsh plants have adapted their belowground organs to the harsh environmental conditions which allows them to successfully develop extensive root systems and ensures survival. Furthermore, their high below-ground biomass is an important contribution to the carbon and nitrogen pools in salt marshes.

In our third study we used stable isotope measurements $\left(\delta^{18} \mathrm{O}\right)$ to investigate plant water use patterns (i.e. the use of saline vs. freshwater) across the saltmarsh flooding gradient. We found a marked gradient in plant water use from the pioneer zone (79-98 \% seawater uptake by Spartina anglica) to the lower marsh (61-95\% in A. portulacoides) and the upper marsh (25-39\% in E. atherica) reflecting the predominant inundation regime at the three elevational levels. Only minor seasonal differences in water use patterns were detected, likely due to the absence of longer dry periods during summer in these temperate salt marshes. A. portulacoides significantly increased its uptake of seawater following transplantation to lower elevations with higher inundation frequencies on experimental islands which were set up within the BEFmate project. This indicates that certain species are able to show a flexible water use strategy under changing inundation frequencies which may enable long-term adaptation to rising sea levels. Integrating the data on vertical fine root distribution and the soil depth of water uptake, we found that fine root mass distribution correlated positively with water uptake across the soil profile. However, contradicting our expectations, the physiological activity of fine roots (determined by the water uptake/root mass ratio) did not decrease with soil depth demonstrating a good functionality of roots in deep and anoxic sediment layers in this habitat.

In conclusion, this thesis demonstrates that saltmarsh plants have developed various species-specific adaptations of their below-ground organs enabling their survival under the harsh environmental conditions prevailing in salt marshes. Interspecific differences particularly corresponded to the gradient of inundation frequency and associated salinity, waterlogging and mechanical disturbance in all three studies. Supporting previous studies, it was underlined that the initial establishment as well as further ecological processes in salt marshes are driven by the gradient of abiotic conditions. 




\section{Table of contents}

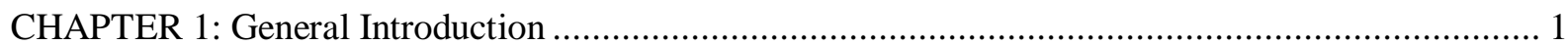

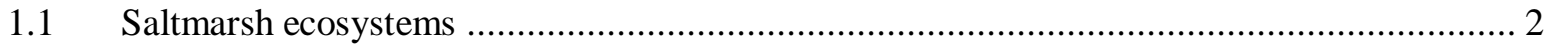

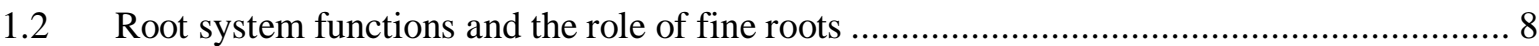

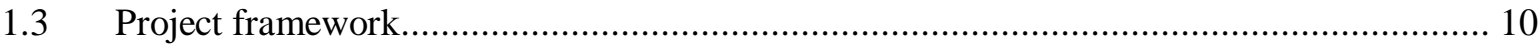

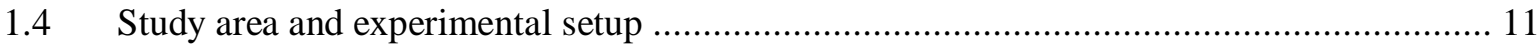

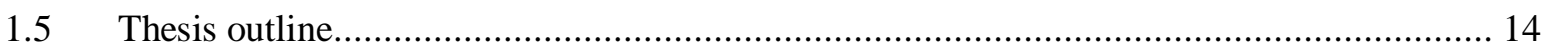

CHAPTER 2: Seedling stability in waterlogged sediments: an experiment with saltmarsh plants ...... 23

CHAPTER 3: Effects of inundation, nutrient availability and plant species diversity on fine root mass

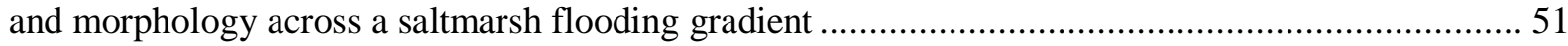

CHAPTER 4: Water sources of plant uptake along a salt marsh flooding gradient .......................... 87

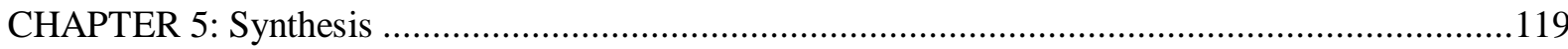

5.1 Below-ground plant traits across the elevational saltmarsh gradient and their relation

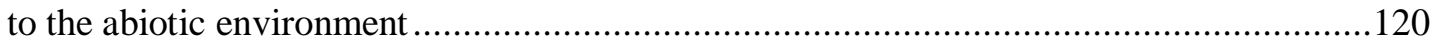

5.2 Saltmarsh plant reactions to changing flooding frequencies .......................................126

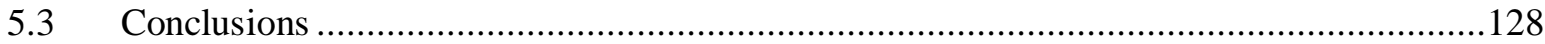

APPENDIX: Cryogenic vacuum extraction and stable isotope analysis .......................................135

A.1 Set up of the cryogenic vacuum extraction line...........................................................

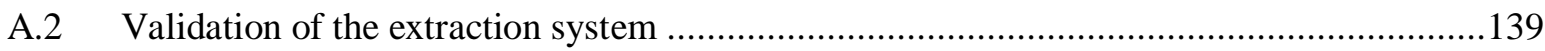

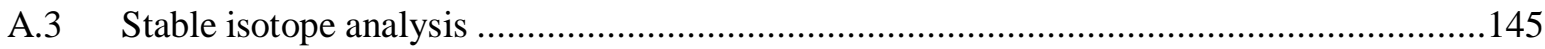

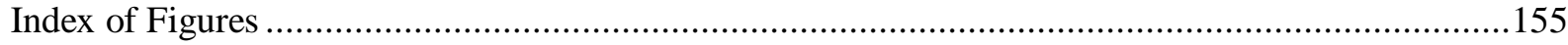

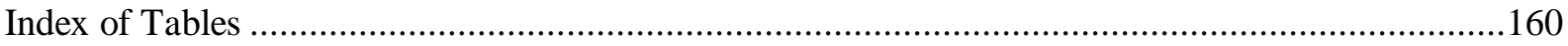

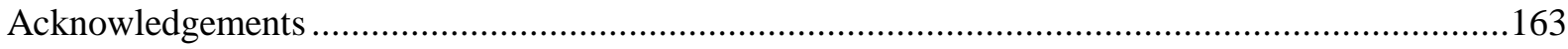

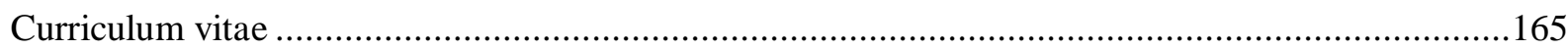

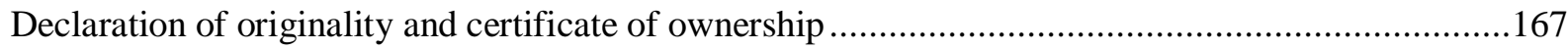





\section{Chapter}

1

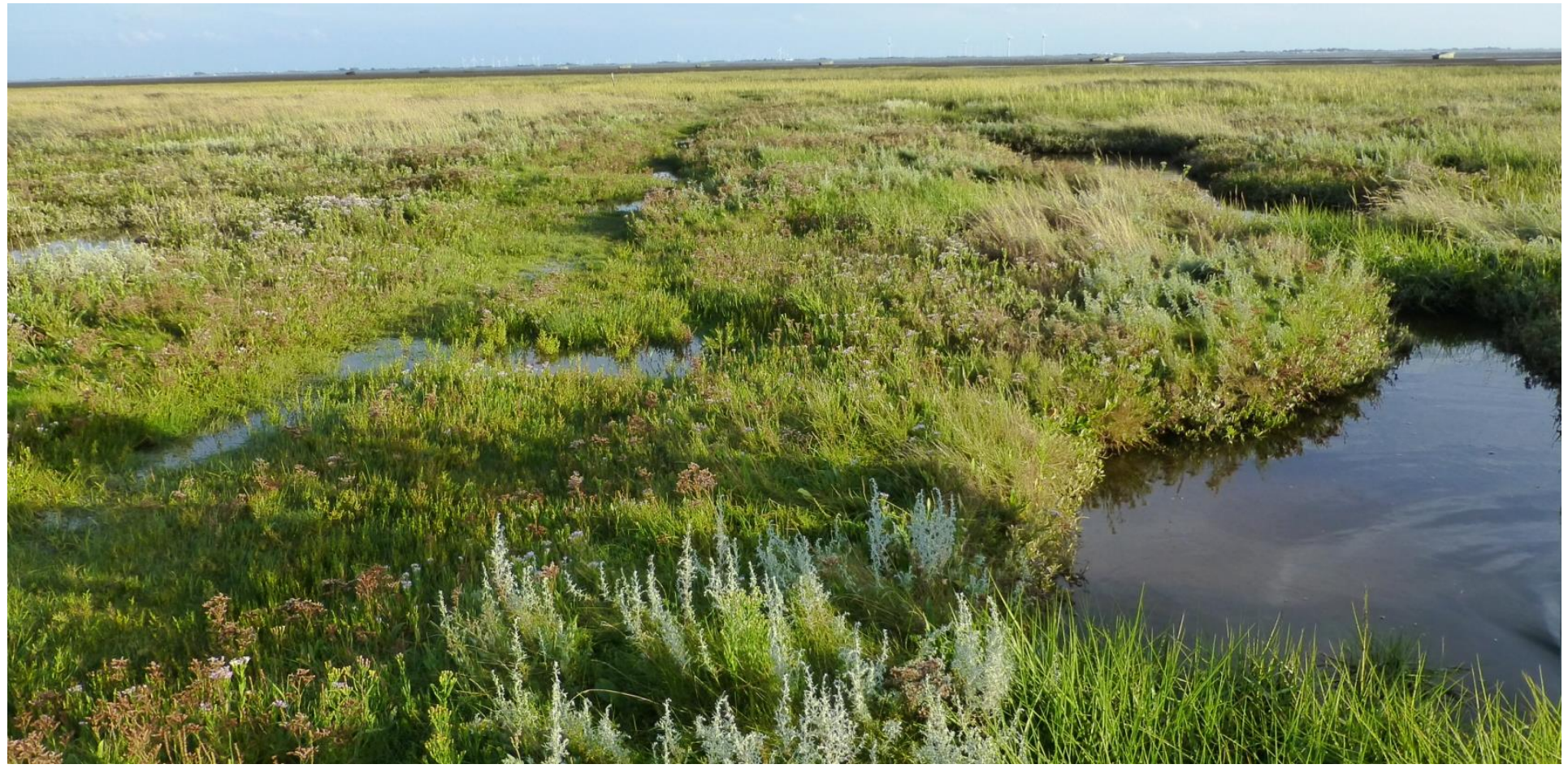

\section{General Introduction}




\section{$1.1 \quad$ Saltmarsh ecosystems}

Vegetated coastal ecosystems are found from the tropics to the arctic at the interface of land and sea and include seagrass beds, salt marshes and mangroves. They are located at the upper part of the intertidal zone in tidal systems and are subjected to regular inundation with seawater. These habitats are characterized by extreme environmental conditions related to frequent flooding with seawater (i.e. salinity, waterlogged and anoxic soils, erosion and sedimentation by wind and wave forces) and are thus inhabited by highly adapted animal and plant communities. In the temperate zone, salt marshes dominate the intertidal wetlands, whereas in tropical and subtropical climate, mangroves are found as coastal ecosystems (Figure 1.1; Tomlinson 1994; Stuart et al. 2007; Saintilan et al. 2014).

In north-west Europe, salt marshes are found mainly in the Wadden Sea along the Dutch, German and Danish North Sea coastline and cover an area of approximately 40,000 ha (Bakker 2014). Saltmarsh vegetation is formed on the mainland in bays at the seaward side of artificial dikes as 'foreland salt marshes', in estuaries, or on the leeward side of barrier islands sheltered by sand dunes ('back-barrier marshes') (Leuschner and Ellenberg 2017).

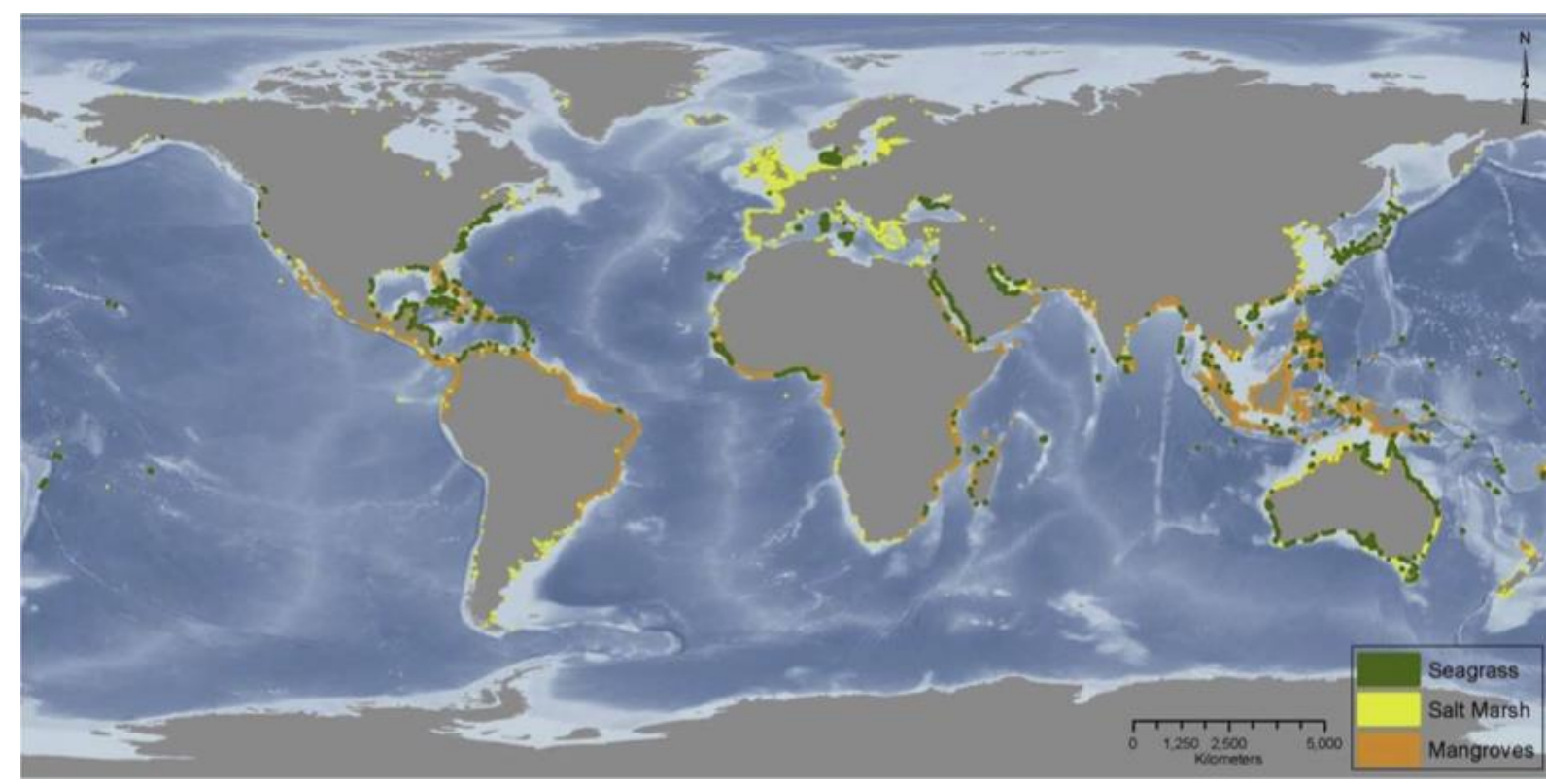

Figure 1.1: Global distribution of vegetated coastal ecosystems including seagrasses, salt marshes and mangroves (Pendleton et al. 2012).

Salt marshes provide numerous valuable ecosystem services (Barbier et al. 2011): they are one of the most productive ecosystems in the world and are very effective in carbon sequestration by burying atmospheric carbon in below-ground biomass (Drake et al. 2015; Mcleod et al. 2011; Artigas et al. 
2015; Mitsch et al. 2013). With around $200 \mathrm{~g} \mathrm{C} \mathrm{m}^{-2}$ year $^{-1}$, the mean long-term carbon sequestration rate of salt marshes is approximately 40 times greater compared to temperate forest ecosystems and 50 times greater compared to carbon sequestration in tropical forests so that the contribution of salt marshes to global carbon burial is comparable to these terrestrial ecosystems despite their much smaller area (Mcleod et al. 2011). Salt marshes provide a unique habitat for diverse flora and fauna; they are of great importance as staging and breeding area for migratory birds and offer breeding and nursery grounds for sheltered living marine species with importance for commercial fisheries (Barbier et al. 2011). Furthermore, they act as filter for runoff water buffering the coastal ocean from eutrophication and pollutants (Nelson and Zavaleta 2012) and play an important role in coastal protection by attenuating wave forces during storm events as well as by sediment stabilization for erosion control (Möller et al. 1999; Ford et al. 2016).

\section{Establishment of salt marshes and zonation}

Saltmarsh establishment can be described by the general concept of biogeomorphic succession, which for example can also be applied to coastal dune, mangrove or fluvial ecosystem establishment (Balke 2013; De Groot et al. 2016; Corenblit et al. 2015; Corenblit et al. 2007). Biogeomorphic succession describes the development from a bare substrate where physical processes dominate to a stabilized ecosystem. During the first phase diaspores and organic material get deposited on open bare flats which are strongly disturbed by hydrodynamics and sediment dynamics ('geomorphic' phase). Deposited driftline material and periods free of hydrodynamic disturbances offer so called 'Windows of Opportunity' (Balke et al. 2011) for germination and initial seedling establishment on bare areas ('pioneer phase'). Species colonizing these bare areas are referred to as pioneer species. When a critical density threshold of pioneer vegetation is reached, feedbacks between vegetation and abiotic processes occur ('biogeomorphic phase'). Plants trap sediment, produce organic matter, which gets decomposed, and they reduce current velocities of wave energy. Due to these processes, the biogeomorphic ecosystem becomes higher, is less flooded, and in turn vegetation gets denser. Finally, a stable vegetation is reached, which is successively decoupled from the marine environment, and biological factors such as competition and symbiosis determine the vegetation structure ('ecological phase').

Salt marshes feature an elevational gradient with increasing distance from the sea, which is accompanied by a gradual change in abiotic conditions due to less frequent inundation. This gradient of elevation and abiotic conditions leads to a typical zonation of salt marshes from the pioneer zone to the upper salt marsh with distinct plant communities in every zone (Figure 1.2; Armstrong et al. 1985; 
Bockelmann et al. 2002). The pioneer zone establishes just above Mean High Water of Neap Tides (MHWN; Balke et al. 2016) and is inundated by most tides except the lowest neap tides. In this zone, inhabiting plants are exposed to extreme environmental stress due to frequent tidal inundation, including high salinity, soil anoxia, increased concentrations of toxic compounds in soil and decreased availability of nutrients (Armstrong et al. 1985; Pennings and Callaway 1992). With increasing elevation, i.e. less frequent inundation, environmental stress decreases, whereas interspecific competition increases (Levine et al. 1998; Crain et al. 2004; Fariña et al. 2009; Pennings and Moore 2001). Just above the Mean High Tide (MHT) line lays the lower saltmarsh zone, which is inundated only by spring tides around 200 times per year. The adjacent upper saltmarsh zone is inundated only during very high spring tides and storm events, which is around 50-100 times per year.

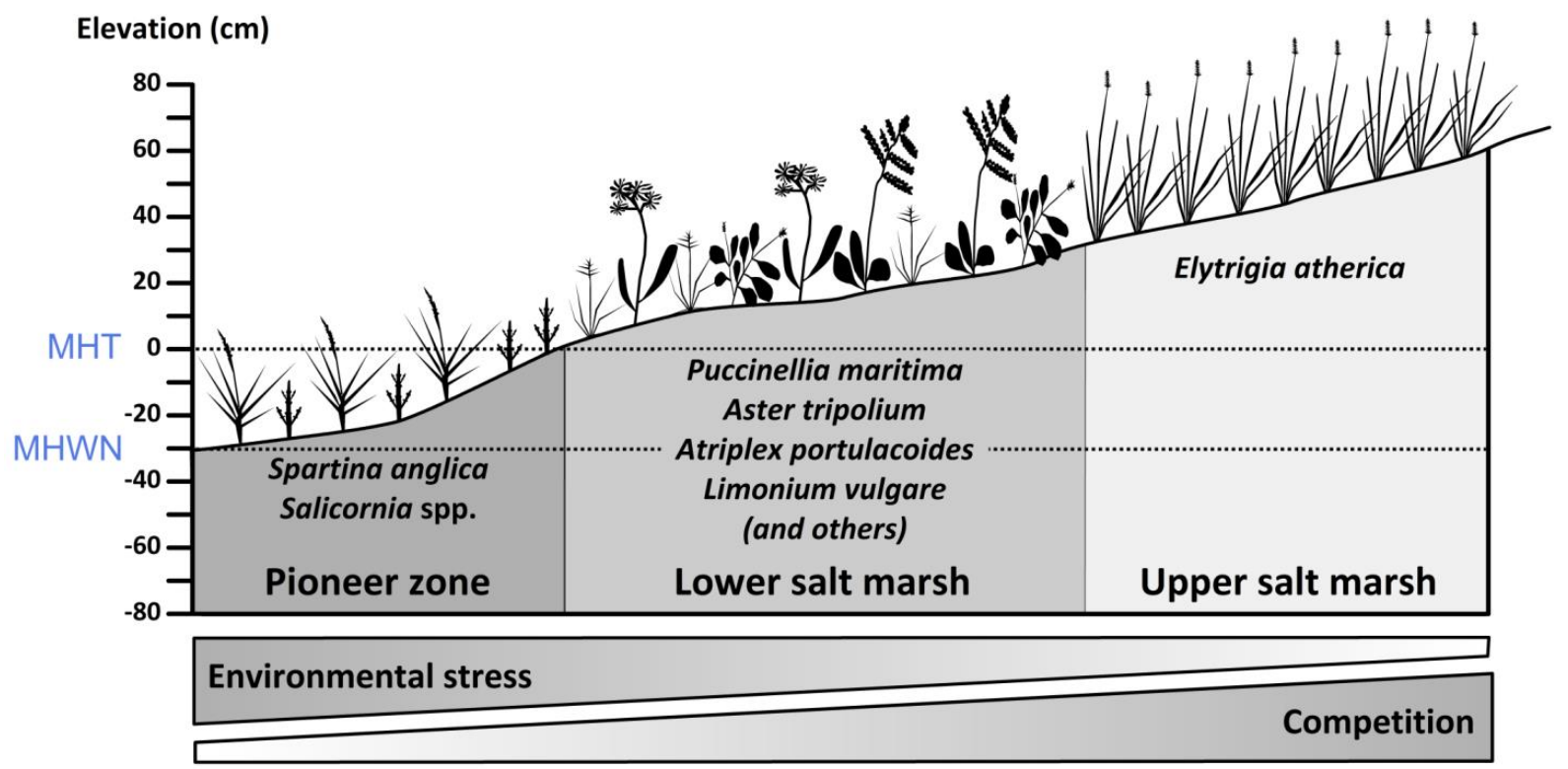

Figure 1.2: The three zones of a NW European salt marsh with their elevations relative to the Mean High Tide (MHT) level and characteristic species. Mean High Water of Neap tides (MHWN) marks the transition from the bare tidal flat to the pioneer zone. Figure by D. Hertel and R. Redelstein.

\section{Saltmarsh plants and their physiological adaptations to environmental stress}

There are several environmental parameters influencing plant species inhabiting the salt marsh with the greatest impact of tidal flooding and thus fluctuating salinity (Rozema et al. 1985; Cooper 1982). Species from the pioneer zone require highest adaptations to these extreme abiotic conditions, which means that this zone is only inhabited by a few species. The dominant species in the pioneer zone of 
north-west European salt marshes is Spartina anglica C.E. Hubb., accompanied by Salicornia spp. Dumort (Figure $1.3 \mathrm{a}, \mathrm{b}$ ). One adaptation of Spartina to waterlogged and anoxic soil conditions is a well-developed aerenchyma tissue for a rapid supply of oxygen from above-ground sources to the below-ground roots and rhizomes so that plants are capable of oxidizing potentially toxic compounds (i.e. sulfide) in the roots and rhizosphere (Lee 1999; Lee 2003; Maricle and Lee 2002; Koop-Jakobsen and Wenzhoefer 2015). Plants of the genus Salicornia are adapted to high soil salinities and have been shown to be the only saltmarsh species with optimal growth under saline conditions (Katschnig et al. 2013). Salicornia accumulates incoming sodium ions in the vacuole in order to keep salt concentrations in the cytoplasm below toxic levels, which drives water uptake into the cells and results in succulent growth (Rozema et al. 1985).

The subsequent lower salt marsh is the most species-rich community with high cover of Atriplex portulacoides L. and Puccinellia maritima (Huds.) Parl., besides occurrence of Cochlearia danica L., Suaeda maritima (L.) Dumort., Limonium vulgare Mill., Artemisia maritima L., Aster tripolium L., Triglochin maritima L., Plantago maritima L. s. str., Salicornia europaea L. s. str., Spartina anglica and Spergularia media (L.) C. Presl at lower frequency (Figure 1.3 b, c).

The upper salt marsh is characterized by monospecific stands of Elytrigia atherica (Link) Kerguélen with only a few individuals of Atriplex prostrata Boucher ex DC (Figure 1.3 d). Elytrigia atherica is a highly competitive species but sensitive to waterlogging so that it spreads rapidly in the rarely inundated upper saltmarsh levels. Its abundance has increased rapidly in several salt marshes along the north-west European North Sea coast (Bockelmann and Neuhaus 1999; Stock et al. 2005). It has been observed that the cessation of livestock grazing in many sites has led to the dominance of Elytrigia atherica and a decrease in the number of other species (Veeneklaas 2013; Veeneklaas et al. 2013; Bakker 1985; van Wijnen and Bakker 1997). Under grazed conditions, the upper salt marsh vegetation is more diverse and includes species such as Festuca rubra L., Armeria maritima (Mill.) Willd. S. 1., Juncus gerardii Loisel., Limonium vulgare, Artemisia maritima, Centaurium littorale (Turner) Gilm. and Potentilla anserina L., among others.

Lower and upper saltmarsh species feature different specific adaptations to salinity which include, besides succulent growth as in Salicornia, Suaeda maritima, Aster tripolium, Glaux maritima, Spergularia media and Triglochin maritimum, salt exclusion or different morphological adaptations. There are several mechanisms of salt exclusion: Spartina or Limonium for example, excrete salt ions by salt glands (Rozema et al. 1985), whereas other species, for example Atriplex-species, develop epidermal salt bladders on the leaf surfaces which accumulate salt ions (Freitas and Breckle 1992). When the bladder is filled with salt, it dies and bursts and releases the salt from the plant. Puccinelliaspecies achieve a reduction of ion uptake by a second endodermal layer in the root, which controls 
transport of ions to the xylem (Stelzer and Läuchli 1977). Morphological adaptations to osmotic stress often resemble xeromorphic structures, which reduce transpiration rate so that the uptake of saline water by the plant can be reduced and include i.e. epicuticular waxes as in Elytrigia (Rozema et al. 1983). A further strategy for osmotic adaptation is the accumulation of nitrogen-based compounds such as proline and methylated quaternary ammonium compounds for intracellular osmotic adjustment, which has been found i.e. in Atriplex portulacoides (Stewart and Lee 1974).
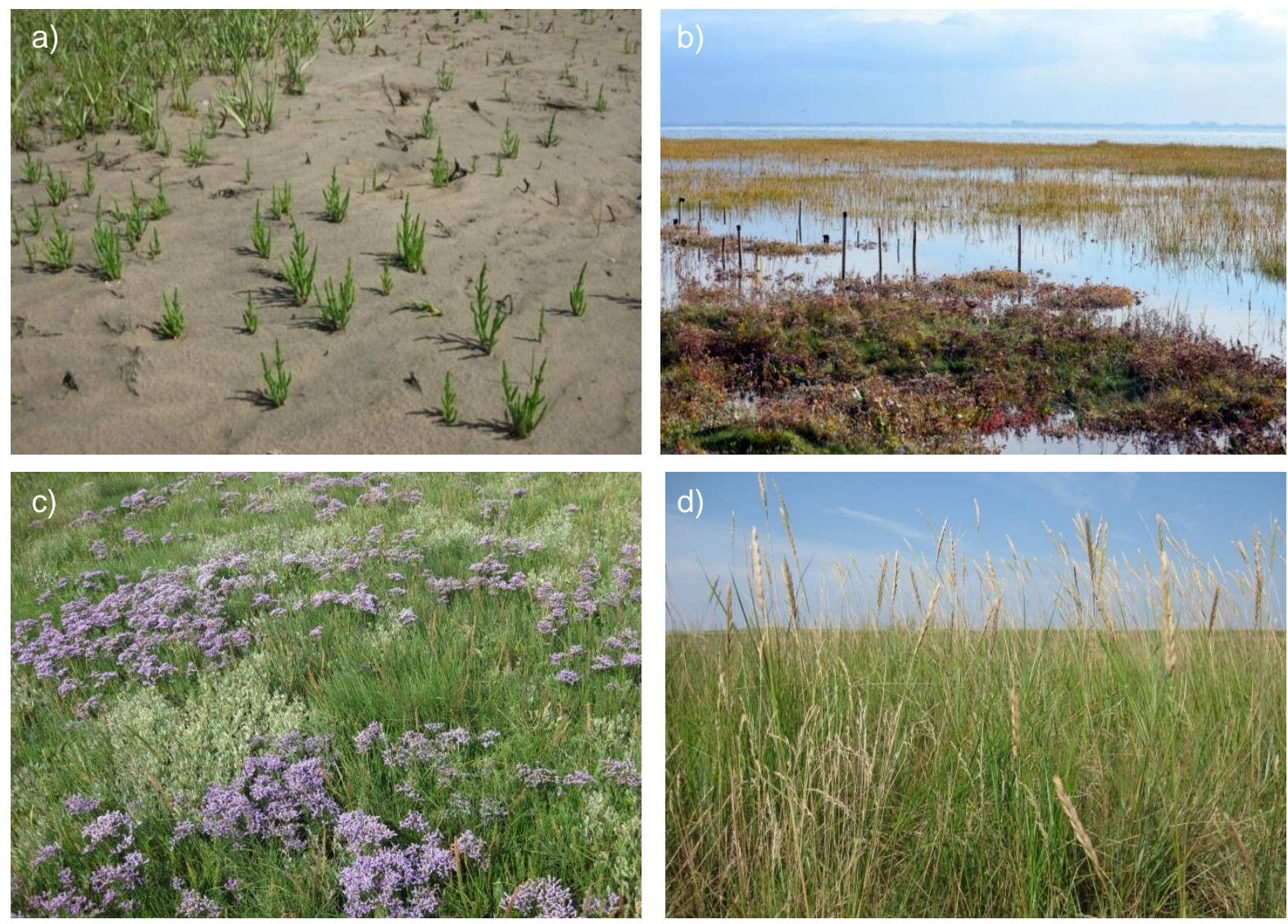

Figure 1.3: Typical vegetation of the three saltmarsh zones in the study areas. a) Establishing vegetation (Salicornia sp.) on a bare tidal flat. b) Lower salt marsh (front) and pioneer zone (Spartina anglica dominated, back) vegetation during tidal inundation. c) Lower saltmarsh vegetation (mainly Limonium vulgare, Atriplex portulacoides, Aster tripolium and Triglochin maritimum). d) Upper salt marsh with a monospecific stand of Elytrigia atherica. Photographs: R. Redelstein.

Salt marshes and sea level rise

Global sea levels have risen through the $20^{\text {th }}$ century and will almost certainly continue to rise even more rapidly in the coming years as a result of global warming (Nicholls and Cazenave 2010). This 
accelerated sea level rise (SLR) is caused by two main factors related to climate change: (i) thermal expansion of sea water due to ocean warming, and (ii) water mass input from melting of glaciers, ice caps and ice sheets (Solomon et al. 2007). Within the North Sea region, there are regional variations in mean sea level rise (Bakker et al. 2016) with a mean SLR of 1-2 $\mathrm{mm}^{-1} \mathrm{y}^{-1}$ in the Wadden Sea region from 1900 to 2000 (Oost et al. 2009). The Intergovernmental Panel on Climate Change (IPCC, Solomon et al. 2007) projects a global mean SLR of $60 \mathrm{~cm}$ by $2100\left(6.7 \mathrm{~mm} \mathrm{year}^{-1}\right)$, but there are several model variants predicting a SLR of between 30 and $180 \mathrm{~cm}$ by 2100 (Nicholls and Cazenave 2010).

Global change and accompanying accelerated sea level rise (SLR) pose a direct threat to salt marshes by increased flooding and finally potential drowning of the salt marsh. There are ongoing discussions on the question whether salt marshes are able to keep pace with SLR (Kirwan et al. 2010; Cahoon and Gutenspergen 2010; Kirwan et al. 2016). In general, saltmarsh survival is assessed by accretion models which are based on minerogenic and organogenic sedimentation rates under conditions of changing sea level, and on sediment compaction (Allen 1990). Salt marshes are able to survive when they grow vertically at rates greater than SLR (Kirwan et al. 2016). Surface elevation change of salt marshes decreases with increasing age of the salt marsh (van Wijnen and Bakker 2001), and differs between mainland and back-barrier salt marshes with higher accretion rates on mainland marshes (Bakker et al. 2016). Therefore, back-barrier marshes with lower vertical accretion may be affected by SLR earlier than mainland marshes. Moreover, rates of surface elevation changes differ within one salt marsh depending on the distance to the seaward edge and to creeks and ditches with greater accretion rates at more frequently inundated sites (i.e. closer to the sea or to creeks and ditches; Bakker et al. 2016). Several models predict increasing inundation frequencies as a result of SLR despite increasing marsh elevation and high accretion rates in the long run depending on the SLR scenario (Schile et al. 2014; van Wijnen and Bakker 2001; Kirwan et al. 2010). Accelerated sea level without sufficient sediment accretion is expected to change the saltmarsh plant communities as increased inundation leads to direct physiological stress to plants by increases of waterlogging or salinity of soils. This may lead to changes in saltmarsh habitats and 'coastal squeeze' (Pontee 2013) when low lying vegetation zones migrate to higher habitats, but higher marsh species are unable to occupy higher habitats due to the barrier of an artificial seawall. It remains to be investigated how far ecosystem services persist in these changing habitats (Roman 2017). In contrast, a meta-analysis of Kirwan et al. (2016) suggests that marshes are building at similar rates to or exceeding historical sea level rise and that accretion rates may double in response to sea level acceleration postulating an overestimation of marsh vulnerability to sea level rise. However, some studies have already found changes in species appearances indicating effects of rising sea level. For example, Veeneklaas et al. 
(2013) have found that on the back-barrier marsh of Schiermonnikoog (The Netherlands), Elytrigia atherica, which is very sensitive to soil waterlogging, has been replaced by Phragmites australis far from the saltmarsh edge. In Southern England, an increasing dominance of more flood-tolerant species (i.e. Spartina alterniflora) has been found (Donnelly and Bertness 2001; Smith 2015).

It may be concluded that effects of sea level rise are very site-specific and may play an important role at some saltmarsh sites in the future. Furthermore, the ability of salt marshes to keep pace with sea level rise is strongly dependent on the occurring SLR scenario (Kirwan et al. 2010). Responses of different plant species to increasing inundation have hardly been investigated and are of great interest in light of the predicted SLR. Therefore, one focus of the presented study (Chapter 4) is on the question whether saltmarsh plants are able to adapt to changing sea levels in terms of their water use, whereas in Chapter 2, we investigated the sensitivity of saltmarsh seedlings to waterlogged soil and their ability to establish under these conditions, which may play an important role in conservation and restoration of salt marsh sites under changing sea levels.

\subsection{Root system functions and the role of fine roots}

Although often considered as the 'hidden half' of plants (Waisel et al. 2002), it is well known that roots have major functions for plant viability. They are responsible for plant anchorage, they absorb water and nutrients from the soil, transport substances from and to the shoot, and store resources. In turn, roots present a main source of organic material for the soil and affect its structure, function and biological activity (Waisel et al. 2002). The present study deals with different aspects of the belowground plant compartment in salt marshes, in particular roots and their functions and interactions with the abiotic conditions. Especially in salt marshes, where plants are continuously exposed to extreme soil conditions, root structure and functions, and their specific adaptations are of great importance for plant viability and ecosystem functioning.

Roots are differentiated between coarse roots with diameters $>2 \mathrm{~mm}$ and fine roots, defined as roots $<2 \mathrm{~mm}$ in diameter. Coarse roots are responsible for storage and transport of nutrients and water as well as for the stabilization of plants, whereas fine roots are responsible for water and nutrient uptake (Jackson et al. 1997; Leuschner and Hertel 2003). Fine roots play a central role in the carbon, nitrogen and hydrological cycles of soils (Gill and Jackson 2000; McCormack et al. 2012). Although they only represent a minor part of total plant biomass, it has been estimated that fine root growth might account for about one third of annual global net primary production (Jackson et al. 1997). They act as an important sink for carbon acquired in terrestrial primary production due to their short lifespan and rapid turnover. Several studies have found relationships between different fine root traits 
and fine root lifespan. Typically investigated root morphological traits include root diameter, specific root length (SRL; root length per weight), specific root area (SRA; root surface area per weight) and root tissue density (RTD; root weight per volume). It was found, for example, that roots with longer lifespan have a higher RTD (Ryser 1996), and lower SRL (McCormack et al. 2012; Eissenstat et al. 2000). This is due to an increased investment in structural carbon per unit root length to optimize nutrient and water transport in longer living roots (Eissenstat and Yanai 1997). Furthermore, an increasing $\mathrm{N}: \mathrm{C}$ ratio in roots may be related to faster growth rates and higher respiration rates and thus, shorter root lifespan of roots (McCormack et al. 2012; Withington et al. 2006).

In forest ecosystems, fine root dynamics and morphology differ depending on the encountered abiotic and biotic conditions such as soil properties, nutrient supply, temperature, water availability, and microbial activities (Leuschner and Hertel 2003; Hertel et al. 2013; Gill and Jackson 2000; Eissenstat et al. 2000). Due to the contrasting soil conditions in the three saltmarsh zones, different root properties may be expected between species across this gradient. Bouma et al. (2003) tested the hypothesis that the fast growing and competitive species Elytrigia atherica from the upper salt marsh would have shorter root lifespan, lower RTD and higher SRL than the stress tolerating and slow growing species Spartina anglica from the pioneer zone. Root lifespan was shorter in E. atherica, however, for both species they found similar RTD which they ascribed to the presence of aerenchyma in S. anglica. A clear relationship between root lifespan and root morphology could thus not be proven for these saltmarsh species. In general, literature on root productivity and morphology in salt marshes is scarce. However, it has been found that below-ground productivity outweighs that of above-ground organs in salt marshes (Smith et al. 1979; Groenendijk and Vinklievaart 1987); for example, fifty to ninety percent of the total annual production of Spartina alterniflora in eastern US salt marshes occurs below ground as roots and rhizomes (Darby and Turner 2008; Valiela et al. 1976). Besides their functions in the soil carbon and nutrient cycle, roots also play an important role in soil aggregation and stabilization in physically disturbed ecosystems such as salt marshes by protecting against erosion (Gould et al. 2016; van Eerdt 1985; Ford et al. 2016).

In the present study, three different root properties and functions of roots from saltmarsh plants were investigated:

1. The impact of root growth for the stability of newly establishing seedlings in physically strongly disturbed ecosystems such as salt marshes.

2. Fine root biomass and morphology as physiologically active parts of the roots responsible for water and nutrient uptake, and their relation to abiotic and biotic conditions in salt marshes. 
3. Water uptake (i.e. the use of saline water sources) of different saltmarsh plants and their ability to adapt to changing inundation frequencies.

\subsection{Project framework}

As biodiversity is globally declining rapidly, which is to a great extent due to human impact (i.e. due to climate change and sea level rise; see also Chapter 1.1 Salt marshes and sea level rise), there are increasing concerns about the consequences for ecosystem functioning with impact on the provision of ecosystem services, and finally on human wellbeing (Balvanera et al. 2006; Cardinale et al. 2012). Functional effects on ecosystems caused by the loss of biodiversity are poorly understood and therefore research on biodiversity-ecosystem functioning (BEF) is becoming of major importance in ecology (Balvanera et al. 2006; Cardinale et al. 2012; Hillebrand and Matthiessen 2009). The presented $\mathrm{PhD}$ project is part of the joint research project 'Biodiversity and Ecosystem Functioning across marine and terrestrial ecosystems' (BEFmate), which addresses the challenges of BEF research especially with regard to the integration of terrestrial and marine ecosystems by formulating five major goals (BEFmate proposal 2013):

1. Understanding biodiversity-ecosystem function relationships across marine and terrestrial ecosystems.

2. Assessing the functional consequences of biodiversity change across the tree of life and across the entire range of biological organization from genes to ecosystems.

3. Merging ecological and evolutionary aspects of functional biodiversity research.

4. Synthesizing BEF research with ecological theory on elemental stoichiometry, species' allometry, and food-web structure.

5. Unraveling how neutral and dispersal processes affect BEF relationships in space and time.

The project is divided into several subprojects which include meta-analyses and modeling as well as field and laboratory experiments and addresses various functional ecosystem processes as well as different levels of biological organization from genes to ecosystems and from microbes to larger organisms of ecosystems at the interface between land and sea, in particular of salt marshes as highly dynamic ecosystems underlying frequent disturbances. Within this joint research project, the present $\mathrm{PhD}$ study was involved in the empirical subprojects.

The main research questions of the empirical subprojects are: How do plankton, plants and animals colonize new habitats in dynamic ecosystems (i.e. coastal marine and terrestrial habitats)? How do the 
properties of newly formed soils affect colonization and establishment of plant and microbial communities? How do ecosystem functions change with the arrival of new species or with the extinction of present species and during the transition of a marine to a terrestrial ecosystem?

To study these research questions, different field and laboratory investigations were conducted within the BEFmate project. Experimental islands were set up in the Wadden Sea to investigate effects of changing sea levels on colonization and succession.

\subsection{Study area and experimental setup}

The study was carried out in the salt marshes and tidal flats of the German National Park Wadden Sea. The National Park Wadden Sea reaches over 450 km along the North Sea coastline of Denmark, Germany and the Netherlands and became UNESCO natural heritage site in 2009. The main study setup was located on Spiekeroog Island (Lower Saxony, 5345'44"N 743'23"E; Figure 1.4), whereas for an additional comparison between geomorphologically different sites a second study site was established in a salt marsh in the Tümlau Bight close to Westerhever (Schleswig-Holstein, $\left.54^{\circ} 22^{\prime} 22^{\prime \prime} \mathrm{N} 8^{\circ} 38^{\prime} 47^{\prime \prime E}\right)$. The two study sites differ from each other in their morphology: the Spiekeroog salt marsh is a back-barrier marsh which developed naturally under the lee of a barrierbeach, whereas the Westerhever salt marsh is a mainland marsh which is largely of anthropogenic origin as it developed by ditching in the early $20^{\text {th }}$ century and has been intensively grazed until 1991 (Stock et al. 2005). At both saltmarsh sites, samples were taken from the three saltmarsh zones with the upper salt marsh being inundated 4 (Spiekeroog) and 8 (Westerhever) times on average per month; the lower salt marsh is inundated approx. 16 times per month at both sites and the pioneer zone is inundated 46 and 20 times, respectively, per month (own data, given in Chapter 3). 


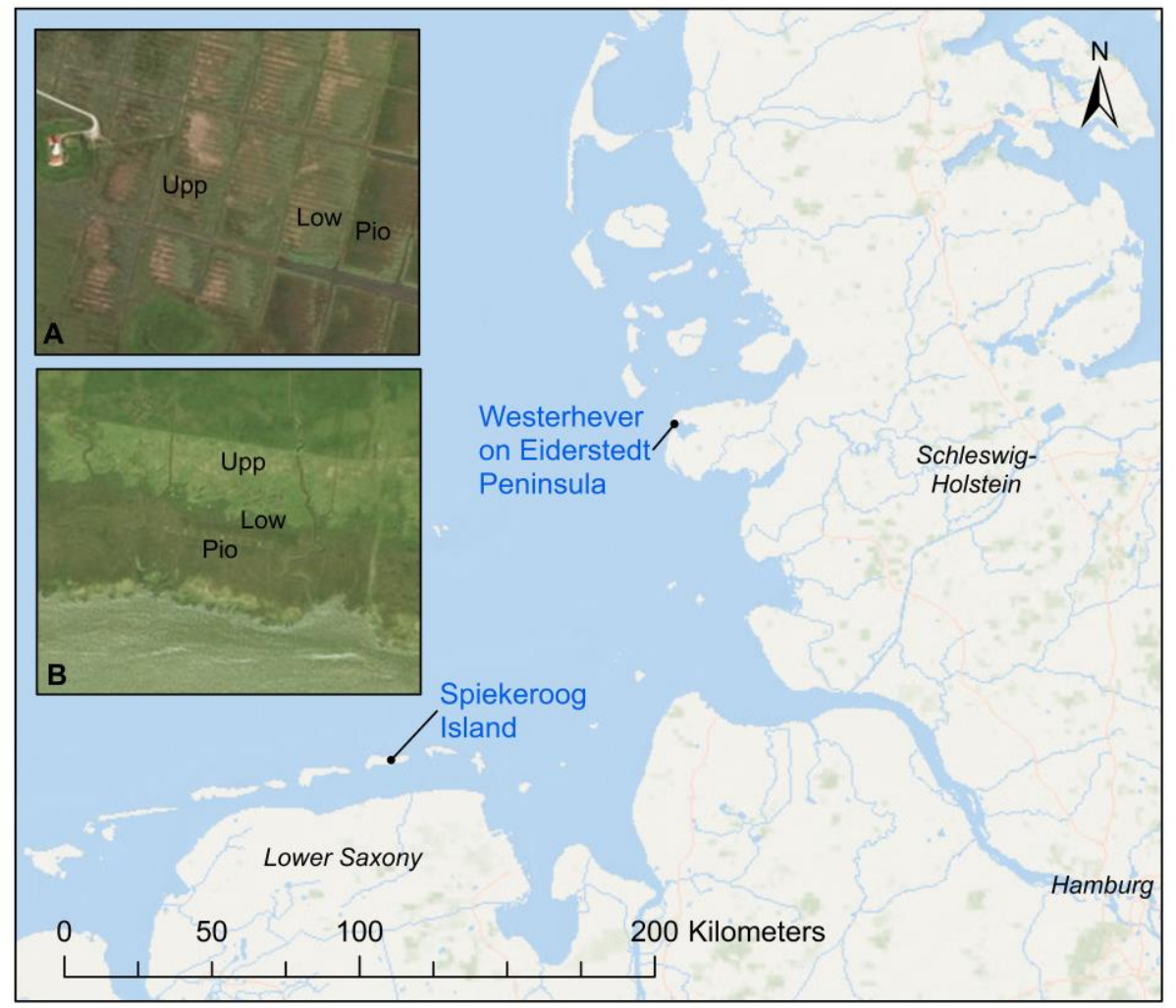

Figure 1.4: Map of the German North Sea coast with the location of the two study sites Spiekeroog Island and Westerhever and location of the sampling plots in the three saltmarsh zones pioneer zone (Pio), lower salt marsh (Low) and upper salt marsh (Upp) (detailed satellite images: Tümlau Bight in Westerhever (A) and south side of Spiekeroog Island (B)) (Service layer Credits: Esri, DeLorme, GEBCO, NOAA NGDB, and other contributors, Source: Esri, DigitalGlobe, GeoEye, Earthstar Geographics, CNES/Airbus DS, USDA, USGS, AeroGRID, IGN, and the GIS User Community).

\section{Experimental setup}

At both study sites, six areas of $2 \times 2 \mathrm{~m}^{2}$ were installed in each saltmarsh zone (pioneer zone, lower salt marsh and upper salt marsh) and marked by bamboo poles, resulting in 18 plots per site. The percentage cover of all plant species in all plots was estimated with the Londo scale to the next $10 \%$ (>10\% cover) or $1 \%(<10 \%$ cover) (results in Chapter 3$)$. For Spiekeroog, these plots are referred to as natural reference plots in addition to the experimental islands.

Experimental islands were set up on the tidal flats on the southern coast of Spiekeroog Island in a distance of approximately $500 \mathrm{~m}$ to the pioneer zone. Each island has three height levels $(70 \mathrm{~cm}$, $100 \mathrm{~cm}$ and $130 \mathrm{~cm}$ ) corresponding to the three zones of the salt marsh in order to obtain similar inundation frequencies as in the natural saltmarsh zones. Each level consists of four steel cages with 
$1 \mathrm{~m}^{2}$ top surface each. Steel cages were lined with a water permeable geotextile $\left(\mathrm{HaTe} \circledast 1000 \mathrm{~g} / \mathrm{m}^{2}\right.$, Huesker, Germany) and polyethylene bags $(0.14 \mathrm{~mm})$ in the lower parts to obtain a level of standing ground water according to the one in the natural salt marsh. The islands were filled with sediment from the surrounding tidal flats. Six of the islands were planted with sods composed of lower saltmarsh communities, so that only the intermediate height level was within the realized niche of lower saltmarsh species. On the lowest and highest levels increased or reduced inundation, respectively, leads to increasing inundation-stress or competition in order to study their effects on species diversity and ecosystem functions. The remaining six islands were not planted and were open for colonization. Detailed description of island construction is shown in Figure 1.5 and given in Balke et al. (2017).
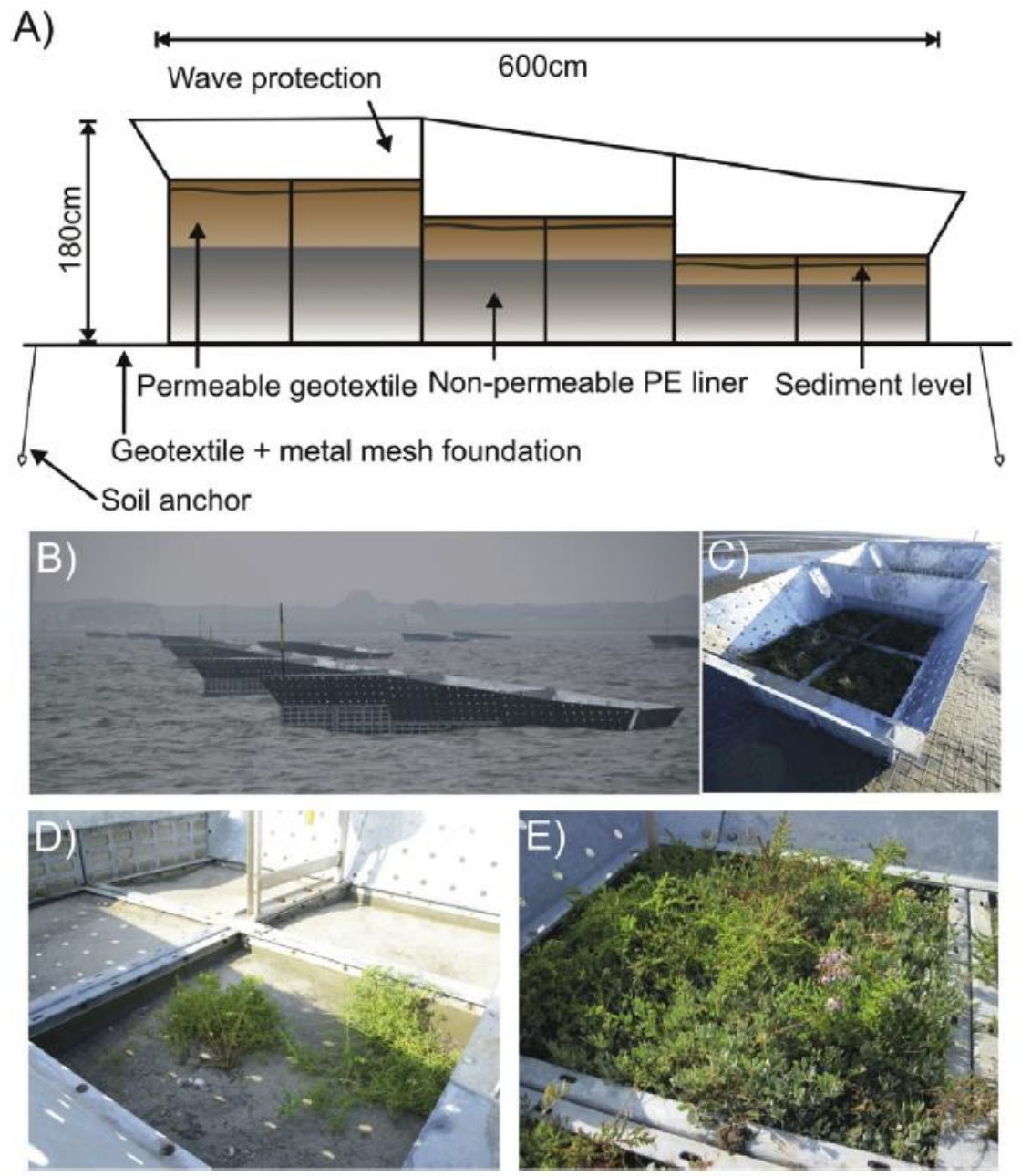

Figure 1.5: A) Design of the experimental islands as given in Balke et al. (2017). B) Experimental islands during tidal flooding. C) View from above on the lower level of an experimental island with four plots of $1 \mathrm{x}$ $1 \mathrm{~m}$. D) Bare plots of experimental islands with first colonization after one year. E) Experimental island plot with vegetation from the lower salt marsh. 


\subsection{Thesis outline}

The presented $\mathrm{PhD}$ thesis includes three studies on different aspects of salt marsh below-ground plant functioning and properties as well as their relation to the abiotic environment. Different approaches in the field and laboratory were undertaken in order to address these research topics. In detail, the research hypotheses and methods underlying the presented $\mathrm{PhD}$ study and the related scientific publications were the following:

1. The first study focused on effects of waterlogged soil conditions on the stability of newly establishing salt marsh seedlings in their physically strongly disturbed habitat (Chapter 2).

The following hypotheses were tested:

(i) Root growth plays an important role for the stability of seedlings to resist physical disturbances as in salt marshes.

(ii) Waterlogged soil conditions negatively affect root growth of developing saltmarsh seedlings, leading to reduced resistance against physical disturbance.

(iii) Seedlings of pioneer zone species cope more successfully with waterlogged soil conditions and are more resistant to physical disturbances (i.e. erosion) under these conditions than lower and upper saltmarsh species.

(iv) Environmental stress (i.e. waterlogged soil) affects root morphology and leads to an increase in specific root length and a decrease in root tissue density, thus increasing the efficiency of soil exploitation at lower construction costs (Eissenstat et al. 2000).

In order to study these hypotheses, a mesocosm experiment was set up. Mesocosms consisted of tanks which were flooded twice per day with seawater and contained pots filled with sediment from the tidal flats in the Wadden Sea. Pots were designed in order to obtain three levels of waterlogging: fully-waterlogged, partly-waterlogged and drained. Seedlings of three saltmarsh species, typical for the three zones of north-west European salt marshes (Salicornia europaea, Atriplex portulacoides, Elytrigia atherica), were planted to the experimental pots. After eight weeks of exposure to the waterlogging treatments, seedlings were subjected to a treatment simulating erosion. Effects of the treatments were related to seedling stability towards erosion, growth and further morphological traits. 
2. In the second study, fine root mass and morphology were related to different abiotic and biotic parameters across the saltmarsh gradient as well as at two sites differing in soil texture, such as inundation frequency, soil nutrient contents, and species diversity (Chapter 3).

The following hypotheses were tested:

(i) Fine root mass is on average greater in the sandy than the silty sediments due to higher nutrient availability in the latter.

(ii) The decrease of rooting depth with increasing soil depth is less pronounced in the pioneer zone due to an assumed greater adaptive potential of the inhabiting species to the anoxic sediment conditions.

(iii) The likely more stress-tolerant species of the frequently inundated pioneer zone have more robust roots with lower specific root area and specific root length, but higher root tissue density than the more competitive species of the upper salt marsh.

(iv) Plant species richness has a positive effect on the root mass of the community.

For these investigations, a field study was conducted. Samples were taken at two field sites at the German North Sea coast differing in sediment texture: from the back-barrier salt marsh of Spiekeroog Island with mainly sandy sediment and from a foreland salt marsh near Westerhever with a very thick layer of clayey sediment. Fine root mass was determined from soil cores taken from the three saltmarsh zones at both sites. Fine roots were scanned to determine morphological traits including root diameter, specific root length, specific root area, and root tissue density, and carbon and nitrogen contents of the roots were analyzed. Additionally, the following soil properties were analyzed: grain size distribution, soil $\mathrm{pH}$, total nitrogen, total carbon, $\mathrm{C}: \mathrm{N}$ ratio of soil, total Na- and S-content, plant-available $\mathrm{P}$ and mineral N content. Soil properties were related to fine root mass and morphology.

3. The third study investigated the contribution of different water sources to plant water use (sea water vs. fresh water; different soil depths) in relation to the location of plants in the salt marsh and changes in plant water use with changing sea level, i.e. in terms of sea level rise (Chapter 4).

The following hypotheses were tested

(i) There is a gradient in plant water use from the pioneer zone to the upper salt marsh along which the use of seawater decreases with increasing distance from the sea. 
(ii) The use of seawater and precipitation water changes seasonally in dependence on precipitation patterns with higher seawater uptake in drier (precipitation-poor) months.

(iii) The relative importance of water uptake from deeper soil layers decreases due to potential anoxia and the presence of toxic substances in deeper soil.

(iv) Typical salt marsh halophytes are flexible in the use of water sources with rising sea levels.

Natural abundances of stable isotopic ratios of oxygen $\left(\delta^{18} \mathrm{O}\right)$ were used to identify the sources of plant water. Since freshwater (e.g. precipitation) is isotopically depleted in ${ }^{18} \mathrm{O}$ compared to seawater, stable isotopic ratios of water extracted from plants can be used to identify the contribution of fresh versus sea water to plant water use (Ehleringer and Dawson 1992; Sternberg et al. 1991; Sternberg and Swart 1987). Plant root crowns, which are expected to reflect the isotopic signature of plant water (Barnard et al. 2006), were collected and the isotopic composition of water extracted from roots was analyzed in comparison to isotopic compositions of precipitation and sea water by means of Cavity Ring-Down Spectroscopy (CRDS). Furthermore, stable isotopic ratios of water extracted from soil sampled from different depths were analyzed and compared to isotopic ratios of plant water by means of stable isotope mixing models in order to determine the soil depth of water uptake.

One major part of the present $\mathrm{PhD}$ study was the setup and validation of the instrumentation and methodology for water extraction of plant and soil material and the measurement of stable isotopes by CRDS. Detailed descriptions of the cryogenic water extraction line and stable isotope analysis, and conducted validation tests are given in the Appendix of this thesis. 


\section{References}

Allen JR (1990) Salt-marsh growth and stratification: a numerical model with special reference to the Severn Estuary, southwest Britain. Marine Geology 95:77-96.

Armstrong W, Wright EJ, Lythe S, Gaynard TJ (1985) Plant zonation and the effects of the springneap tidal cycle on soil aeration in a humber salt-marsh. Journal of Ecology 73:323-339.

Artigas F, Shin JY, Hobble C, Marti-Donati A, Schaefer KVR, Pechmann I (2015) Long term carbon storage potential and $\mathrm{CO}_{2}$ sink strength of a restored salt marsh in New Jersey. Agricultural and Forest Meteorology 200:313-321. doi:10.1016/j.agrformet.2014.09.012.

Bakker JP (1985) The impact of grazing on plant communities, plant populations and soil conditions on salt marshes. Vegetatio 62:391-398.

Bakker JP (2014) Ecology of salt marshes. 40 years of research in the Wadden Sea. Wadden Academy.

Bakker JP, Baas AC, Bartholdy J, Jones L, Ruessink G, Temmerman S, van de Pol M (2016) Environmental Impacts-Coastal Ecosystems. in North Sea Region Climate Change Assessment, Regional Climate studies, Quante M., Colijn F. (eds). Springer Open:275-314.

Balke T (2013) Establishment of biogeomorphic ecosystems. A study on mangrove and salt marsh pioneer vegetation. Dissertation. Radboud University, Nijmegen.

Balke T, Bouma TJ, Horstman EM, Webb EL, Erftemeijer PL, Herman PM (2011) Windows of opportunity: thresholds to mangrove seedling establishment on tidal flats. Marine Ecology Progress Series 440:1-9. doi:10.3354/meps09364.

Balke T, Lõhmus K, Hillebrand H, Zielinski O, Haynert K, Meier D, Hodapp D, Minden V, Kleyer M (2017) Experimental salt marsh islands: A model system for novel metacommunity experiments. Estuarine, Coastal and Shelf Science 198:288-298. doi:10.1016/j.ecss.2017.09.021.

Balke T, Stock M, Jensen K, Bouma TJ, Kleyer M (2016) A global analysis of the seaward salt marsh extent: The importance of tidal range. Water Resources Research 52:3775-3786. doi:10.1002/2015WR018318.

Balvanera P, Pfisterer AB, Buchmann N, He J-S, Nakashizuka T, Raffaelli D, Schmid B (2006) Quantifying the evidence for biodiversity effects on ecosystem functioning and services. Ecology letters 9:1146-1156. doi:10.1111/j.1461-0248.2006.00963.x.

Barbier EB, Hacker SD, Kennedy C, Koch EW, Stier AC, Silliman BR (2011) The value of estuarine and coastal ecosystem services. Ecological Monographs 81:169-193. doi:10.1890/10-1510.1.

Barnard RL, Bello F de, Gilgen AK, Buchmann N (2006) The $\delta^{18} \mathrm{O}$ of root crown water best reflects source water $\delta^{18} \mathrm{O}$ in different types of herbaceous species. Rapid Communications in Mass Spectrometry 20:3799-3802. doi:10.1002/rcm.2778. 
BEFmate proposal (2013) Biodiversity-Ecosystem Functioning across marine and terrestrial ecosystems. Proposal for a Collaborative Project by Carl von Ossietzky University of Oldenburg and Georg August University Göttingen.

Bockelmann AC, Bakker JP, Neuhaus R, Lage J (2002) The relation between vegetation zonation, elevation and inundation frequency in a Wadden Sea salt marsh. Aquatic Botany 73:211-221. doi:10.1016/S0304-3770(02)00022-0.

Bockelmann AC, Neuhaus R (1999) Competitive exclusion of Elymus athericus from a high-stress habitat in a European salt marsh. Journal of Ecology 87:503-513.

Bouma TJ, Hengst K, Koutstaal BP, van Soelen J (2002) Estimating root lifespan of two grasses at contrasting elevation in a salt marsh by applying vitality staining on roots from in-growth cores. Plant Ecology 165:235-245.

Cahoon DR, Gutenspergen GR (2010) Climate change, sea-level rise, and coastal wetlands. National Wetlands Newsletter 32:8-12.

Cardinale BJ, Duffy JE, Gonzalez A, Hooper DU, Perrings C, Venail P, Narwani A, Mace GM, Tilman D, Wardle DA, Kinzig AP, Daily GC, Loreau M, Grace JB, Larigauderie A, Srivastava DS, Naeem S (2012) Biodiversity loss and its impact on humanity. Nature 486:59-67. doi:10.1038/nature11148.

Cooper A (1982) The effects of salinity and waterlogging on the growth and cation uptake of salt marsh plants. New Phytologist 90:263-275.

Corenblit D, Baas AC, Balke T, Bouma TJ, Fromard F, Garófano-Gómez V, González E, Gurnell AM, Hortobágyi B, Julien F, Kim D, Lambs L, Stallins JA, Steiger J, Tabacchi E, Walcker R (2015) Engineer pioneer plants respond to and affect geomorphic constraints similarly along water-terrestrial interfaces world-wide. Global Ecology and Biogeography 24:1363-1376. doi:10.1111/geb.12373.

Corenblit D, Tabacchi E, Steiger J, Gurnell AM (2007) Reciprocal interactions and adjustments between fluvial landforms and vegetation dynamics in river corridors. A review of complementary approaches. Earth-Science Reviews 84:56-86. doi:10.1016/j.earscirev.2007.05.004.

Crain CM, Silliman BR, Bertness SL, Bertness MD (2004) Physical and biotic drivers of plant distribution across estuarine salinity gradients. Ecology 85:2539-2549.

Darby FA, Turner RE (2008) Below- and aboveground Spartina alterniflora production in a Louisiana salt marsh. Estuaries and Coasts 31:223-231. doi:10.1007/s12237-007-9014-7.

De Groot AV, Oost AP, Veeneklaas RM, Lammerts EJ, van Duin WE, van Wesenbeeck BK (2016) Tales of island tails: biogeomorphic development and management of barrier islands. Journal of Coastal Conservation.

Donnelly JP, Bertness MD (2001) Rapid shoreward encroachment of salt marsh cordgrass in response to accelerated sea-level rise. Proceedings of the National Academy of Sciences 98:14218-14223.

Drake K, Halifax H, Adamowicz SC, Craft C (2015) Carbon sequestration in tidal salt marshes of the northeast United States. Environmental Management 56:998-1008. doi:10.1007/s00267-0150568-z. 
Ehleringer JR, Dawson TE (1992) Water uptake by plants: perspectives from stable isotope composition. Plant, Cell and Environment 15:1073-1082.

Eissenstat DM, Wells CE, Yanai RD, Whitbeck JL (2000) Building roots in a changing environment: implications for root longevity. New Phytologist 147:33-42.

Eissenstat DM, Yanai RD (1997) The ecology of root lifespan. In: Handley LL, Scrimgeour CM (eds), Terrestrial plant ecology and N-15 natural abundance: The present limits to interpretation for uncultivated systems with original data from a Scottish old field, Vol 27, pp 1-60.

Fariña JM, Silliman BR, Bertness MD (2009) Can conservation biologists rely on established community structure rules to manage novel systems? ... Not in salt marshes. Ecological Applications 19:413-422.

Ford H, Garbutt A, Ladd C, Malarkey J, Skov MW (2016) Soil stabilization linked to plant diversity and environmental context in coastal wetlands. Journal of Vegetation Science 27:259-268. doi:10.1111/jvs.12367.

Freitas H, Breckle SW (1992) Importance of bladder hairs for salt tolerance of field-grown Atriplex species from a Portuguese salt marsh. Flora 187:283-297.

Gill RA, Jackson RB (2000) Global patterns of root turnover for terrestrial ecosystems. New Phytologist 147:13-31. doi:10.1046/j.1469-8137.2000.00681.x.

Gould IJ, Quinton JN, Weigelt A, Deyn GB de, Bardgett RD, Seabloom E (2016) Plant diversity and root traits benefit physical properties key to soil function in grasslands. Ecology letters 19:11401149. doi:10.1111/ele.12652.

Groenendijk AM, Vinklievaart MA (1987) Primary production and biomass on a Dutch salt-marsh emphasis on the belowground component. Vegetatio 70:21-27.

Hertel D, Strecker T, Mueller-Haubold H, Leuschner C (2013) Fine root biomass and dynamics in beech forests across a precipitation gradient - is optimal resource partitioning theory applicable to water-limited mature trees? Journal of Ecology 101. doi:10.1111/1365-2745.12124.

Hillebrand H, Matthiessen B (2009) Biodiversity in a complex world: consolidation and progress in functional biodiversity research. Ecology letters 12:1405-1419. doi:10.1111/j.14610248.2009.01388.x.

Jackson RB, Mooney HA, Schulze E-D (1997) A global budget for fine root biomass, surface area, and nutrient contents. Proceedings of the National Academy of Sciences 94:7362-7366. doi:10.1073/pnas.94.14.7362.

Katschnig D, Broekman R, Rozema J (2013) Salt tolerance in the halophyte Salicornia dolichostachya Moss: Growth, morphology and physiology. Environmental and Experimental Botany 92:32-42. doi:10.1016/j.envexpbot.2012.04.002.

Kirwan ML, Guntenspergen GR, D'Alpaos A, Morris JT, Mudd SM, Temmerman S (2010) Limits on the adaptability of coastal marshes to rising sea level. Geophysical Research Letters 37:L23401. doi:10.1029/2010GL045489. 
Kirwan ML, Temmerman S, Skeehan EE, Guntenspergen GR, Fagherazzi S (2016) Overestimation of marsh vulnerability to sea level rise. Nature Climate Change 6:253-260. doi:10.1038/NCLIMATE2909.

Koop-Jakobsen K, Wenzhoefer F (2015) The dynamics of plant-mediated sediment oxygenation in Spartina anglica rhizospheres-a planar optode study. Estuaries and Coasts 38:951-963. doi:10.1007/s12237-014-9861-y.

Lee RW (1999) Oxidation of sulfide by Spartina alterniflora roots. Limnology and Oceanography 44:1155-1159.

Lee RW (2003) Physiological adaptations of the invasive cordgrass Spartina anglica to reducing sediments. Rhizome metabolic gas fluxes and enhanced $\mathrm{O}_{2}$ and $\mathrm{H}_{2} \mathrm{~S}$ transport. Marine Biology 143:9-15. doi:10.1007/s00227-003-1054-3.

Leuschner C, Ellenberg H (2017) Ecology of Central European Non-Forest Vegetation: Coastal to Alpine, Natural to Man-Made Habitats. Vegetation Ecology of Central Europe Volume II. Chapter 1: Salt Marshes and Inland Saline Habitats. Springer Nature, Cham.

Leuschner C, Hertel D (2003) Fine root biomass of temperate forests in relation to soil acidity and fertility, climate, age and species. Progress in Botany 64:405-438.

Levine JM, Brewer JS, Bertness MD (1998) Nutrients, competition and plant zonation in a New England salt marsh. Journal of Ecology 86:285-292.

Maricle BR, Lee RW (2002) Aerenchyma development and oxygen transport in the estuarine cordgrasses Spartina alterniflora and S. anglica. Aquatic Botany 74:109-120.

McCormack ML, Adams TS, Smithwick EAH, Eissenstat DM (2012) Predicting fine root lifespan from plant functional traits in temperate trees. New Phytologist 195:823-831. doi:10.1111/j.14698137.2012.04198.x.

Mcleod E, Chmura GL, Bouillon S, Salm R, Bjork M, Duarte CM, Lovelock CE, Schlesinger WH, Silliman BR (2011) A blueprint for blue carbon: toward an improved understanding of the role of vegetated coastal habitats in sequestering $\mathrm{CO}_{2}$. Frontiers in Ecology and the Environment 9:552560. doi:10.1890/110004.

Mitsch WJ, Bernal B, Nahlik AM, Mander U, Zhang L, Anderson CJ, Jorgensen SE, Brix H (2013) Wetlands, carbon, and climate change. Landscape Ecology 28:583-597. doi:10.1007/s10980-0129758-8.

Möller I, Spencer T, French, JR, Leggett DJ, Dixon M (1999) Wave transformation over salt marshes: A field and numerical modelling study from north Norfolk, England. Estuarine, Coastal and Shelf Science 49:411-426.

Nelson JL, Zavaleta ES (2012) Salt marsh as a coastal filter for the oceans: changes in function with experimental increases in nitrogen loading and sea-level rise. PloS one 7:e38558. doi:10.1371/journal.pone.0038558.

Nicholls RJ, Cazenave A (2010) Sea-level rise and its impact on coastal zones. Science (New York) 328:1517-1520. doi:10.1126/science.1185782. 
Oost A, Kabat P, Wiersma A, Hofstede J (2009) Climate Change Thematic Report No. 4.1. In: Marencic H., de Vlas J. (eds) Wadden Sea Quality Status Report. Wadden Sea Ecosystems No. 25.

Pendleton L, Donato DC, Murray BC, Crooks S, Jenkins WA, Sifleet S, Craft C, Fourqurean JW, Kauffman JB, Marbà N, Megonigal P, Pidgeon E, Herr D, Gordon D, Baldera A (2012) Estimating global "blue carbon" emissions from conversion and degradation of vegetated coastal ecosystems. PloS one 7:e43542. doi:10.1371/journal.pone.0043542.

Pennings SC, Callaway RM (1992) Salt-marsh plant zonation - The relative importance of competition and physical factors. Ecology 73:681-690.

Pennings SC, Moore DJ (2001) Zonation of shrubs in western Atlantic salt marshes. Oecologia 126:587-594.

Pontee N (2013) Defining coastal squeeze: A discussion. Ocean \& Coastal Management 84:204-207. doi:10.1016/j.ocecoaman.2013.07.010.

Roman CT (2017) Salt marsh sustainability: Challenges during an uncertain future. Estuaries and Coasts 40:711-716. doi:10.1007/s12237-016-0149-2.

Rozema J, Bijwaard P, Prast G, Broekman R (1985) Ecophysiological adaptations of coastal halophytes from foredunes and salt marshes. Vegetatio 62:499-521.

Rozema J, Vanmanen Y, Vugts HF, Leusink A (1983) Airborne and soilborne salinity and the distribution of coastal and inland species of the genus Elytrigia. Acta botanica Neerlandica $32: 447-456$.

Ryser P (1996) The importance of tissue density for growth and life span of leaves and roots: A comparison of five ecologically contrasting grasses. Functional Ecology 10:717-723.

Saintilan N, Wilson NC, Rogers K, Rajkaran A, Krauss KW (2014) Mangrove expansion and salt marsh decline at mangrove poleward limits. Global Change Biology 20:147-157. doi:10.1111/gcb.12341.

Schile LM, Callaway JC, Morris JT, Stralberg D, Parker VT, Kelly M (2014) Modeling tidal marsh distribution with sea-level rise: evaluating the role of vegetation, sediment, and upland habitat in marsh resiliency. PloS one 9. doi:10.1371/journal.pone.0088760.

Smith KK, Good RE, Good NF (1979) Production dynamics for above and belowground components of a New Jersey Spartina alterniflora tidal marsh. Estuarine and Coastal Marine Science 9:189201.

Smith SM (2015) Vegetation change in salt marshes of Cape Cod national seashore (Massachusetts, USA) between 1984 and 2013. Wetlands 35:127-136. doi:10.1007/s13157-014-0601-7.

Solomon S, Qin D, Manning M, Chen Z, Marquis M, Averyt KB, Tignor M, Miller HL (2007) Contribution of working group I to the fourth assessment report of the Intergovernmental Panel on Climate Change. Cambridge University Press.

Stelzer R, Läuchli A (1977) Salt tolerance and flooding tolerance of Puccinellia peisonis. 1. Effect of $\mathrm{NaCl}$-salinity and $\mathrm{KCl}$-salinity on growth at varied oxygen-supply to root. Zeitschrift für Pflanzenphysiologie 83:35-42. 
Sternberg LdSL, Ish-Shalom-Gordon N, Ross M, O’Brien J (1991) Water relations of coastal plant communities near the ocean/freshwater boundary. Oecologia 88:305-310. doi:10.1007/BF00317571.

Sternberg LdSL, Swart PK (1987) Utilization of freshwater and ocean water by coastal plants of southern Florida. Ecology 68:1898-1905.

Stewart GR, Lee JA (1974) The role of proline accumulation in halophytes. Planta 120:279-289. doi:10.1007/BF00390296.

Stock M, Gettner M, Hagge H, Heinzel K, Kohlus J, Stumpe H (2005) Salzwiesen an der Westküste von Schleswig-Holstein 1998 - 2001, Vol 15. Schriftenreihe des Nationalparks SchleswigHolsteinisches Wattenmeer, Boyens Buchverlag, Heide.

Stuart SA, Choat B, Martin KC, Holbrook NM, Ball MC (2007) The role of freezing in setting the latitudinal limits of mangrove forests. New Phytologist 173:576-583. doi:10.1111/j.14698137.2006.01938.x.

Tomlinson PB (1994) The Botany of Mangroves. Cambridge Tropical Biology Series.

Valiela I, Teal JM, Persson NY (1976) Production and dynamics of experimentally enriched salt marsh vegetation: Belowground biomass. Limnology and Oceanography 21:245-252.

van Eerdt MM (1985) The influence of erosion and accretion in salt marshes of the Oosterschelde, The Netherlands. Vegetatio 62:367-373.

van Wijnen HJ, Bakker JP (1997) Nitrogen accumulation and species replacement in three salt marsh systems in the Wadden Sea. J Coast Conserv 3:19-26.

van Wijnen HJ, Bakker JP (2001) Long-term surface elevation change in salt marshes: a prediction of marsh response to future sea-level rise. Estuarine, Coastal and Shelf Science 52:381-390. doi:10.1006/ecss.2000.0744.

Veeneklaas RM (2013) Adaptation and dispersal of native salt-marsh species Elytrigia atherica. PhDThesis. University of Groningen.

Veeneklaas RM, Dijkema KS, Hecker N, Bakker JP (2013) Spatio-temporal dynamics of the invasive plant species Elytrigia atherica on natural salt marshes. Applied Vegetation Science 16:205-216. doi:10.1111/j.1654-109X.2012.01228.X.

Waisel Y, Eshel A, Beeckman T, eds, Plant roots: The Hidden Half, $3^{\text {rd }}$ edn. Dekker, Basel, Switzerland.

Withington JM, Reich PB, Oleksyn J, Eissenstat DM (2006) Comparisons of structure and life span in roots and leaves among temperate trees. Ecological Monographs 76:381-397. 


\section{CHAPTER}

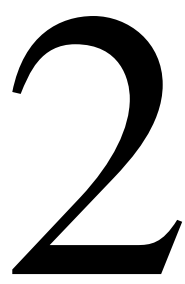

Seedling stability in waterlogged sediments: an experiment with saltmarsh plants

Regine Redelstein, Gerhard Zotz, Thorsten Balke

Published in

Marine Ecology Progress Series 2018, Vol. 590, p. 95-108

doi:10.3354/meps 12463 


\begin{abstract}
Saltmarsh seedlings are exposed to extreme soil conditions in combination with mechanical disturbance by waves and tides, especially at the seaward fringe. We tested whether soil waterlogging affects resistance of seedlings against physical disturbance, thereby potentially influencing the distribution of saltmarsh species. A mesocosm experiment was conducted to investigate effects of waterlogging on plant traits, in particular root growth, and tolerance of seedlings against sediment erosion. Three species, each dominating different elevations in NW European salt marshes (Salicornia europaea, Atriplex portulacoides and Elytrigia atherica), were selected for the experiments. Individual seedlings were grown under different waterlogging treatments and finally subjected to an erosion treatment. The depth of erosion at which the seedlings toppled $\left(\mathrm{E}_{\text {crit }}\right)$ was determined and related to above- and below-ground morphological traits of the seedlings. Resistance against erosion decreased in all three species from drained to completely waterlogged soil conditions, with the strongest negative impact of waterlogging on the upper marsh species E. atherica. Root length and biomass, shoot biomass and the root:shoot biomass ratio were the most important traits positively affecting $\mathrm{E}_{\text {crit. }}$ The experiment demonstrates that rapid root growth is essential for the stability of seedlings, which is presumably of great importance for their successful establishment on tidal flats where sediment erosion may be a limiting factor. Root growth, in turn, is affected by a species-specific response to waterlogging. Our study suggests that this species-specific effect of waterlogging on seedling stability contributes to species sorting along the inundation gradient of coastal ecosystems.
\end{abstract}

Keywords: Coastal ecosystems, Erosion, Root growth, Species distribution, Tidal inundation, Vegetation establishment 


\subsection{Introduction}

The establishment of seedlings is a crucial phase in plant ontogeny (Grubb 1977). Salt marshes are dynamic ecosystems with phases of lateral expansion, when new vegetation establishes on tidal flats, and phases of retreat due to lateral erosion or drowning (Balke et al. 2014; Bouma et al. 2016). Saltmarsh seedlings generally establish above Mean High Water of Neap Tides (MHWN, Balke et al. 2016) and are exposed to extreme abiotic conditions, particularly during immersion. Vascular saltmarsh plants require a high degree of adaptation to their physically and physiologically stressful habitat (Bertness and Ellison 1987; van Diggelen 1991; Noe and Zedler 2000). Regular inundation by seawater leads to high salinity of saltmarsh soils and to waterlogged soil conditions accompanied by soil anoxia, increased concentrations of toxic compounds and decreased availability of nutrients (Armstrong et al. 1985; Pennings and Callaway 1992). High concentrations of soluble sulfide in waterlogged soils are both directly toxic to plants and reduce availability of essential elements such as $\mathrm{Fe}, \mathrm{Mn}, \mathrm{Cu}$ and $\mathrm{Zn}$ (Havill et al. 1985; Lamers et al. 2013). Apart from waterlogged soil conditions, seedling establishment in salt marshes is strongly impacted by physical disturbance by waves and tidal currents. Resuspension of sediment from the tidal flat can lead to short-term erosion of several centimeters (Hu et al. 2015; Hu et al. 2017) and hence to toppling or excavation of seedlings.

With increasing distance from the sea (i.e. increasing elevation and less frequent inundation) there is a gradual change in abiotic conditions leading to a zonation of saltmarsh vegetation with distinct species compositions (Fig.1; Armstrong et al. 1985; Bockelmann et al. 2002). Salinity and flooding are the main abiotic factors controlling the establishment and species distribution in saltmarsh plant communities (Cooper 1982; Armstrong et al. 1985; Rozema et al. 1985; Ungar 1998). The local determinants of plant zonation in salt marshes may also include herbivory and facilitation (Ungar 1998; Noe and Zedler 2001; Ewanchuk and Bertness 2004; Pennings et al. 2005; Davy et al. 2011; He et al. 2015). In general, the seaward edge of the salt marsh is only inhabited by a few species, which are able to tolerate stressful abiotic conditions, whereas at higher elevations more competitive and less stress-tolerant species prevail (Levine et al. 1998; Rand 2000; Pennings and Moore 2001; Crain et al. 2004; Fariña et al. 2009).

Waterlogged soil conditions are common, especially in the lower salt marsh zones, and may directly affect saltmarsh vegetation through reduced germination of seeds (Clarke and Hannon 1970), the inhibition of root emergence at the seedling stage (Wijte and Gallagher 1996), or through growth inhibition in general (Cooper 1982). These effects vary between species from different saltmarsh zones, which leads to the characteristic vegetation pattern (Clarke and Hannon 1970). However, it has not been assessed how the tolerance against erosion of different saltmarsh species is affected by 
waterlogging and how this influences the observed zonation. In general, seedlings are less tolerant to stressful environmental conditions than adult plants (Ungar 1978), while their establishment is crucial for vegetation formation. The first step of successful establishment of a seedling on the tidal flat is the rapid anchoring during a disturbance-free period, the so-called Window of Opportunity (Balke et al. 2014). After anchoring, seedling survival depends on resistance to dislodgement by hydrodynamic forces as well as on physiological abilities to cope with abiotic stress in tidally inundated soils (Balke et al. 2011; Davy et al. 2011; Friess et al. 2012).

Waterlogged soils in combination with physical disturbance affect a number of ecosystems besides salt marshes. In riparian floodplains, seedling survival is strongly dependent on the hydrological regime, sediment erosion and deposition as well as the ability to root quickly (Segelquist et al. 1993; Mahoney and Rood 1998; Corenblit et al. 2007). Similarly, seagrass beds have been found to die off during events of extreme soil anoxia (Moore et al. 1993). However, populations of Zostera marina are able to recolonize quickly after such anoxic crises despite continuous sediment resuspension and strong hydrodynamic forces. This is due to rapid vegetative expansion after initial seedling recolonization (Plus et al. 2003). Waterlogging and associated anoxic soil reduce root growth and rooting depth across different wetland ecosystems (Visser et al. 1996; Bouma et al. 2001). This reduced development of plant roots should in turn make plants more susceptible to physical disturbance and thus play an essential role for the distribution of vascular plants along inundation and disturbance gradients. The interactive effects of seedling trait plasticity due to waterlogging and physical disturbance leading to plant toppling are currently poorly understood, despite their potential relevance across biogeomorphic ecosystems (Corenblit et al. 2015).

Our study addresses the effect of waterlogged soil conditions on the stability of newly establishing seedlings in physically disturbed ecosystems such as salt marshes. We conducted a mesocosm experiment using seedlings of three species dominating the three saltmarsh zones in NW European salt marshes: the annual pioneer species Salicornia europaea (Chenopodiaceae), which dominates the lowest margin of the salt marsh (i.e. the 'pioneer zone', Fig. 2.1), the dwarf shrub Atriplex portulacoides (Chenopodiaceae) from the lower salt marsh, and Elytrigia atherica (Poaceae), which occupies well-aerated soils in the upper salt marsh. The pioneer zone just above MHWN is inundated during almost every high tide throughout the year (Balke et al. 2017) and species are subjected to permanently waterlogged and reduced soil conditions. The lower salt marsh lies just above the Mean High Tide (MHT) level and is inundated only during high water of spring tides, and the upper salt marsh is only inundated during very high spring tides and storm events. The lower and upper saltmarsh soils are generally well-drained and aerated during most of the summer (Armstrong et al. 1985; Veeneklaas et al. 2013). 


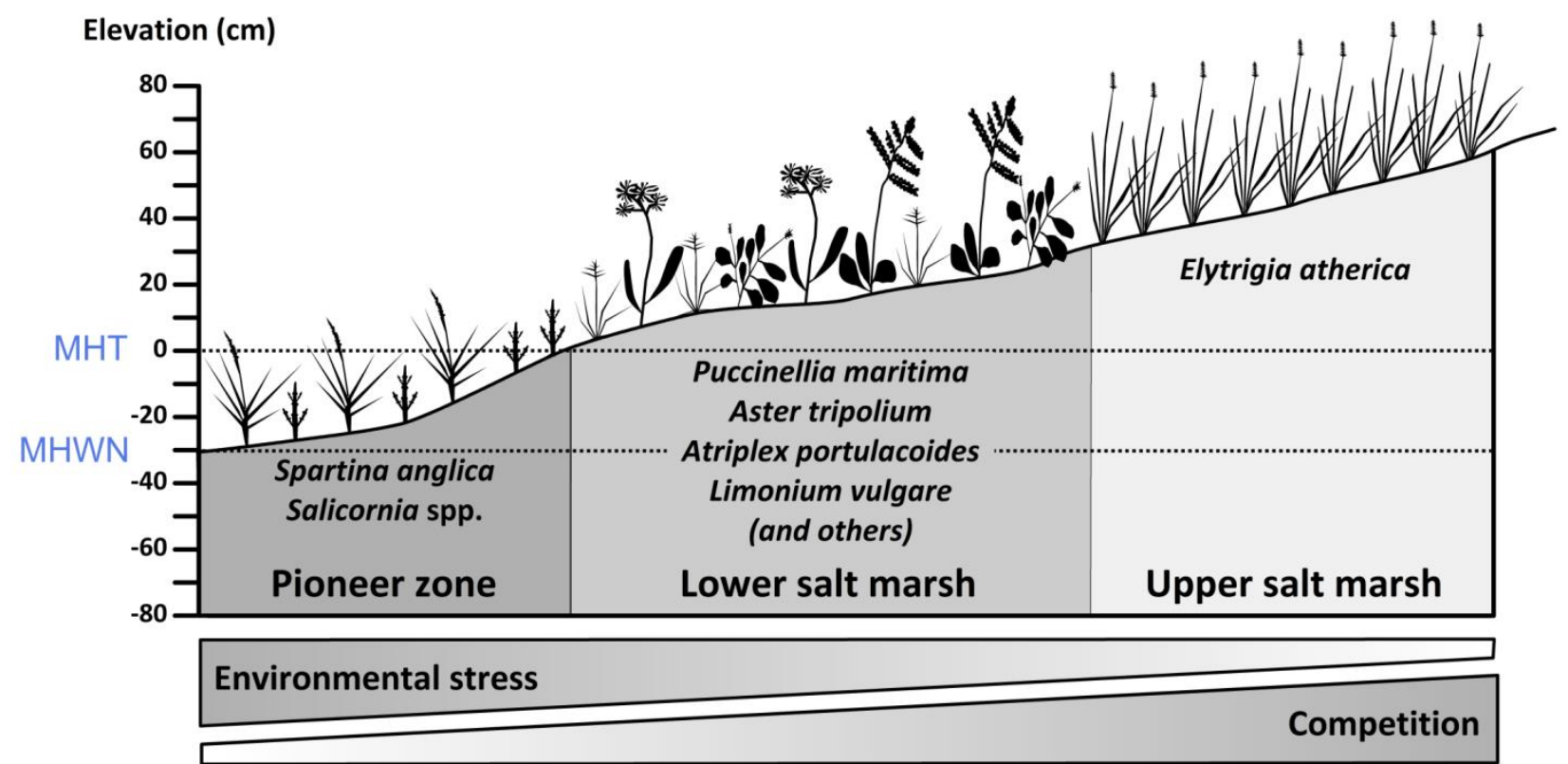

Figure 2.1: The three zones of a NW European salt marsh with their elevations relative to the Mean High Tide (MHT) level and characteristic species. Mean High Water of Neap tides (MHWN) marks the transition from the bare tidal flat to the pioneer zone. Figure modified from Redelstein et al. (2018).

Considering the lack of data on early root growth in the context of intertidal wetland succession (Friess et al. 2012), our study focuses on below-ground growth of seedlings in relation to shoot growth under the given experimental conditions. We hypothesize that: (i) Root growth plays an important role for the ability of seedlings to resist physical disturbances. (ii) Waterlogged soil conditions negatively affect root growth of developing saltmarsh seedlings, leading to reduced resistance against physical disturbance. (iii) Seedlings of pioneer zone species cope more successfully with waterlogged soil conditions and are more resistant to physical disturbances (i.e. erosion) under these conditions than lower and upper saltmarsh species. (iv) Environmental stress (i.e. waterlogged soil) affects root morphology and leads to an increase in specific root length and a decrease in root tissue density, thus increasing the efficiency of soil exploitation at lower construction costs (Eissenstat et al. 2000).

Understanding the combined effects of soil waterlogging and disturbance on species distribution across the elevational gradient of the saltmarsh environment is an important step towards a better understanding of marsh zonation and improving the design of conservation and restoration measures. This is especially important in light of accelerated sea level rise and changing wave climates. 
Furthermore, linking soil anoxia and seedling stability to key plant traits allows to draw conclusions that are also relevant for vegetation establishment in other frequently flooded and physically disturbed ecosystems (e.g. mangroves, riparian forests or seagrass beds).

\subsection{Materials and Methods}

Three experimental tanks ( $1 \mathrm{~m} \times 1 \mathrm{~m}$ x $0.5 \mathrm{~m}$, length $\mathrm{x}$ width $\mathrm{x}$ height $)$ were set up in a greenhouse at the Institue for Chemistry and Biology of the Marine Environment (ICBM) Terramare Wilhelmshaven (University of Oldenburg, Germany). A fourth tank that served as water reservoir was placed beneath the three experimental tanks. Tidal inundation was simulated by pumping water from the reservoir to the experimental tanks (Eheim universal pump 1048, 600 1/h; EHEIM GmbH \& Co. KG, Deizisau, Germany). Seawater was mixed with freshwater to obtain a salinity of 6.5 , which corresponded to the salinity of the natural sediment collected from Jade Bay, Germany

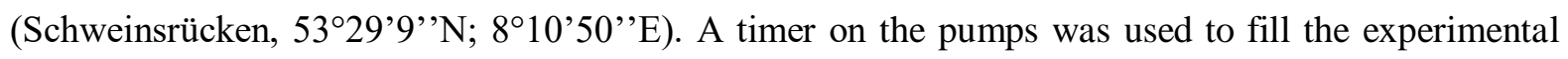
tanks automatically, while switching off the pumps resulted in drainage of the upper tank through the pump back into the reservoir. An overflow return pipe inside the experimental tanks maintained the water depth at approximately $80 \mathrm{~mm}$ above the top of the plant pots. Each experimental tank was flooded twice daily for $1.5 \mathrm{~h}$, once during daytime and once at night. Salinity in the mesocosms was measured every 2-3 days and maintained at 6.5 by the addition of fresh water to compensate for evaporation.

Seeds of Salicornia europaea, Atriplex portulacoides and Elytrigia atherica were collected in the salt marsh at the south side of the East Frisian Island Spiekeroog (Germany, 5345'44''N; 743'23''E) in autumn 2014, air dried and stored dry at $7^{\circ} \mathrm{C}$ until the start of the experiment in early summer 2015 . Experimental pots were made from PVC pipes of $12 \mathrm{~cm}$ diameter and $15 \mathrm{~cm}$ length. The pots were prepared in order to obtain three different levels of waterlogging within the pots: (a) drained, (b) partly-waterlogged and (c) waterlogged. Treatments were chosen to simulate permanently waterlogged soils on the tidal flats (i.e. initial location of pioneer establishment) and better drained soils in the lower and upper saltmarsh zones. For the drained treatment, slits were cut into the sides of the pots and pots were lined with a water permeable fleece to allow complete drainage. For the partlywaterlogged treatment, holes with a diameter of $3 \mathrm{~mm}$ were drilled into the upper three centimeters of the pots. The lower part of the pots, which was not perforated, was lined with a plastic bag. In addition, fleece was inserted into the pots to avoid sediment loss through the holes. For the waterlogged treatment, pots were entirely lined with plastic bags. Sediment was collected from the tidal flats of the Jade Bay. The grain size distribution of the sediment was: Sand (> $63 \mu \mathrm{m})$ : $95.9 \%$; 
Silt $(<63 \mu \mathrm{m}): 4.1 \%$; Clay $(<2 \mu \mathrm{m}): 0 \%$. After collection, the sediment was frozen at $-18{ }^{\circ} \mathrm{C}$ for three days in order to remove any live zoobenthos. Afterwards, the sediment was sieved (mesh size: $5 \mathrm{~mm}$ ) and filled into the experimental pots. The pots were placed into the experimental tanks. Seven days after initiation of the tidal regime different redox-potentials became established according to the treatments (Table 2.1) and seedlings were transferred to the experimental pots (see below). Redoxpotential was measured as an index for soil aeration and we expected waterlogged treatments to be associated with low redox-potentials (Davy et al. 2011). Each experimental tank included one reference pot per treatment without a seedling to measure redox-potential. This was done every 2-3 days throughout the experiment at three different sediment depths $(2.5 \mathrm{~cm}, 5 \mathrm{~cm}$ and $10 \mathrm{~cm})$ at varying locations in each reference pot by means of a metal combination electrode with an $\mathrm{Ag} / \mathrm{AgCl}$ reference system $(3 \mathrm{M} \mathrm{KCl})$ and a platinum sensor (Pt 61, SI Analytics GmbH, Mainz, Germany). Measured values were corrected by adding the potential of the reference electrode $(210 \mathrm{mV})$ with respect to the standard hydrogen electrode. In addition, the redox-potential was measured in the three saltmarsh zones and on the tidal flat with beginning seedling colonization at Spiekeroog Island (Table 2.1).

Table 2.1: Sediment redox-potential (means \pm se) measured at different sediment depths for the three treatments of the mesocosm experiment and in the three saltmarsh zones and a tidal mudflat at Spiekeroog Island (Germany). Measurements at the field site were taken during the growing period (August). Measured values were corrected by adding the potential of the reference electrode $(210 \mathrm{mV})$ with respect to the standard hydrogen electrode.

\begin{tabular}{|c|c|c|c|c|c|c|c|}
\hline \multirow{3}{*}{$\begin{array}{c}\text { Sediment } \\
\text { depth }\end{array}$} & \multicolumn{7}{|c|}{ Redox-potential (mV) } \\
\hline & \multicolumn{3}{|c|}{ Mesocosm experiment } & \multicolumn{4}{|c|}{ Field Measurement } \\
\hline & Drained & $\begin{array}{c}\text { Partly } \\
\text { waterlogge } \\
\text { d }\end{array}$ & Waterlogged & $\begin{array}{l}\text { Upper salt } \\
\text { marsh }\end{array}$ & $\begin{array}{l}\text { Lower } \\
\text { salt } \\
\text { marsh }\end{array}$ & $\begin{array}{c}\text { Pioneer } \\
\text { zone }\end{array}$ & $\begin{array}{c}\text { Mudflat } \\
\text { with initial } \\
\text { colonization }\end{array}$ \\
\hline \multirow[t]{2}{*}{$2.5 \mathrm{~cm}$} & +126.5 & +107.5 & +6.2 & +412.7 & +345.6 & +236.0 & +87.0 \\
\hline & \pm 9.1 & \pm 7.9 & \pm 5.32 & \pm 10.8 & \pm 10.2 & \pm 33.2 & \pm 107.0 \\
\hline \multirow[t]{2}{*}{$5 \mathrm{~cm}$} & -2.5 & +4.1 & -18.2 & +409.0 & +355.7 & +289.2 & -26.6 \\
\hline & \pm 5.2 & \pm 8.0 & \pm 3.4 & \pm 7.3 & \pm 30.0 & \pm 36.5 & \pm 92.2 \\
\hline \multirow[t]{2}{*}{$10 \mathrm{~cm}$} & -54.2 & -39.9 & -40.4 & +424.0 & +371.8 & +254.9 & -196.9 \\
\hline & \pm 2.7 & \pm 3.1 & \pm 2.3 & \pm 11.5 & \pm 25.0 & \pm 55.0 & \pm 19.0 \\
\hline
\end{tabular}

Seeds were sown in the same sediment outside of the mesocosms and seedlings were transferred 34 days after germination to the experimental pots. Each pot was planted with one seedling with visible cotyledons and a size of a few millimeters (Fig. 2.2a). Seedlings were assigned to pots using a random number list whereby species and treatments were distributed evenly among the three 
experimental tanks. Per species and treatment, 18 (E. atherica and S. europaea) or 12 (A. portulacoides) replicate pots were used. The seedlings were grown in the experimental pots inside the mesocosms for a period of 47 to 55 days and monitored throughout the experiment for survival and height three times per week. On the last day, all surviving seedlings were subjected to an erosion treatment. Following previous studies (see Han et al. 2012 for seagrass; Balke et al. 2013 for mangroves; Cao et al. 2017 for Spartina spp.), erosion was mimicked by placing $3 \mathrm{~mm}$ thick discs from the bottom into the experimental pots and pushing the sediment above the edge of the pot. Protruding sediment was carefully removed by water spray without breaking seedlings or roots. Additional discs were inserted until the seedlings toppled under their own weight (Fig. 2.2b). The depth of sediment removed was defined as the critical erosion depth $\left(\mathrm{E}_{\text {crit }}\right)$.

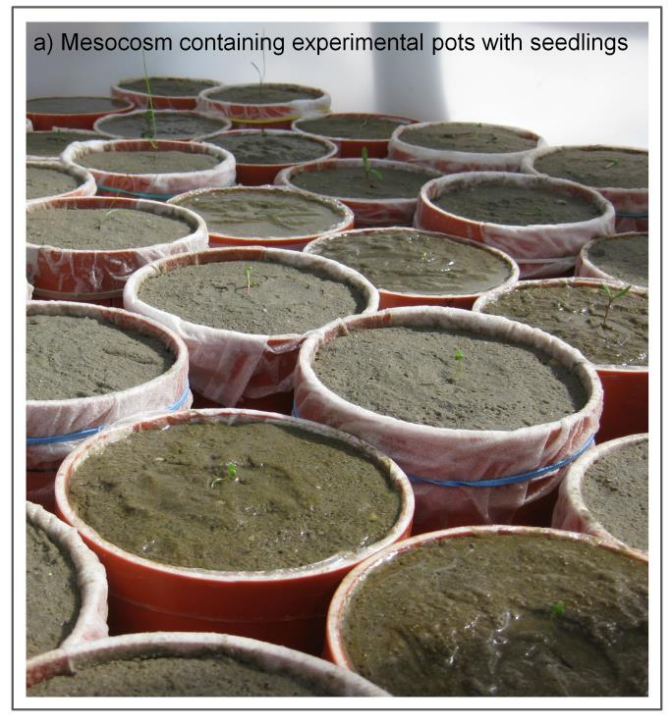

Figure 2.2: (a) Mesocosm with experimental pots containing seedlings of Salicornia europaea, Atriplex portulacoides and Elytrigia atherica grown from seeds collected from a NW European salt marsh. The pots were prepared in order to simulate 3 different levels of waterlogging (1) drained, (2) partly waterlogged and (3) waterlogged. (B) Design and implementation of a test to simulate erosion and determine the critical erosion depth (Ecrit) of each species. Photographs: R. Redelstein.

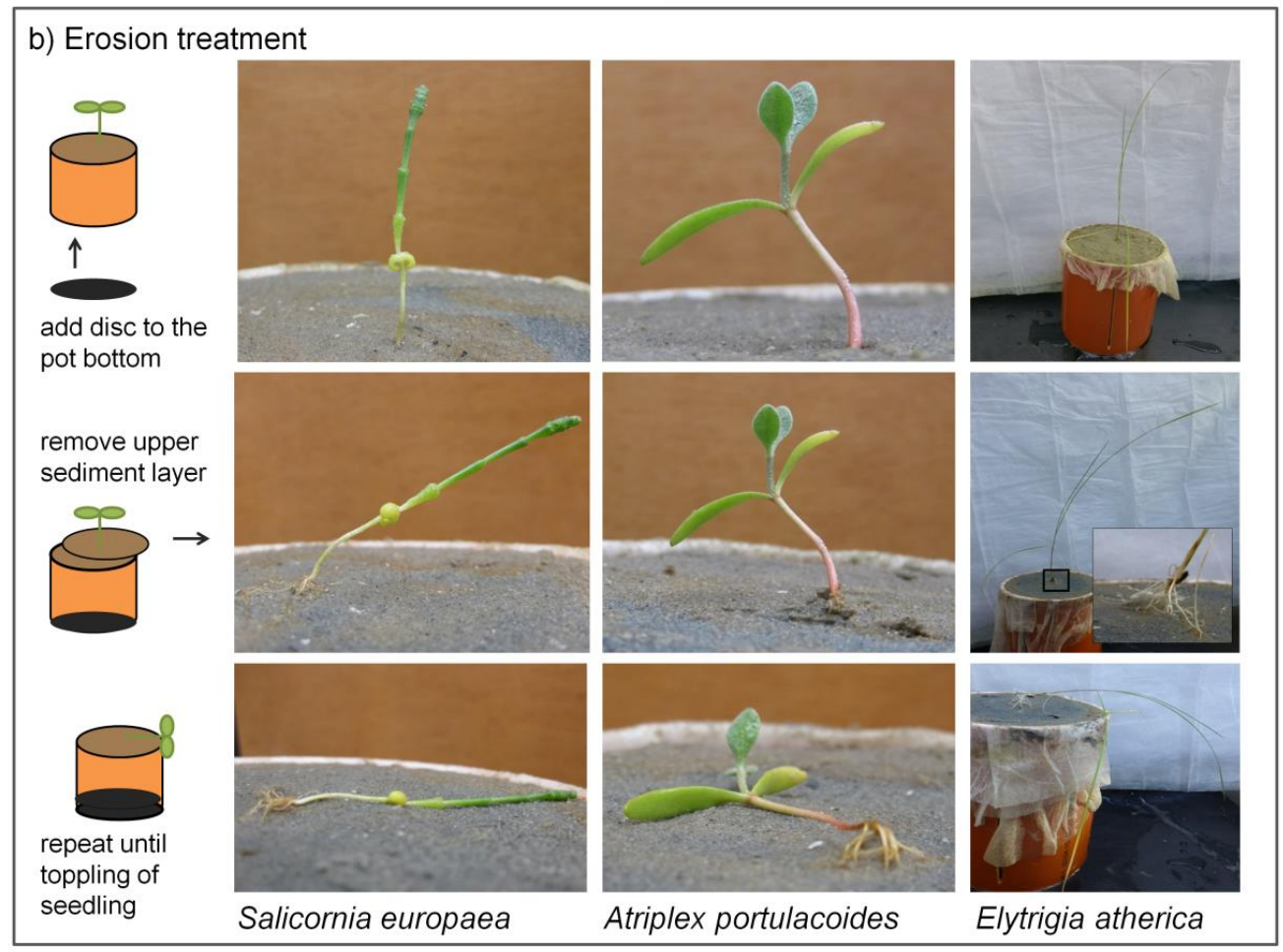


Toppled seedlings were removed from the sediment, washed and maximal root length (length of the longest root) and shoot height were determined. Fresh roots and shoots were separated from each other, the roots were scanned under a flatbed scanner and total root length, root surface area, root volume and root diameter were determined using the software WinRhizo (Regent Instruments, Quebec, Canada). After scanning, roots and shoots were oven dried at $70^{\circ} \mathrm{C}$ for $72 \mathrm{~h}$ and weighed to determine dry mass. Specific root length (SRL, root length/root dry weight), specific root area (SRA, root surface area/root dry weight) and root tissue density (RTD, root dry weight/root volume) were calculated from these measurements.

In addition, Salicornia spp. seedlings from a natural tidal flat close to a salt marsh near Westerhever

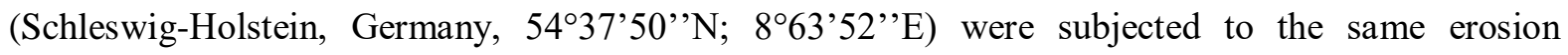
treatment by entering one of the experimental pots into the sediment around a seedling, digging out the pot containing the seedling and surrounding sediment, and performing the critical erosion test as described above. Seedlings were brought to the laboratory, washed, maximal root length and shoot height were determined and roots were scanned, dried and weighed for the determination of root morphological traits as described above. Seedlings were chosen with a similar shoot height as the seedlings grown in the mesocosm experiment. Due to difficult differentiation between taxa at the seedling stage and the challenging taxonomy of Salicornia in general (Kadereit et al. 2012), we here refer to the genus Salicornia spp.

Statistical analyses were conducted using R 3.3.2 software (R Development Core Team 2016). A growth curve for each species was fitted to a three parameter-logistic growth model according to Paine et al. (2012) using the R package 'nlme' (equation 2.1):

$$
H_{t}=\frac{H_{0} \cdot K}{H_{0}+\left(K-H_{0}\right) \cdot e^{-r \cdot t}}
$$

Equation 2.1

where $\mathrm{H}_{t}$ is seedling height at time $\mathrm{t}, \mathrm{H}_{0}$ is seedling height at start of experiment (when transferred to experimental pots), $\mathrm{K}$ is seedling height at harvest, and $\mathrm{r}$ is relative growth rate. $\mathrm{H}_{0}, \mathrm{~K}$ and $\mathrm{r}$ were treated as random effects on the individual level. To test for differences between treatments the restricted maximum likelihood method was used.

To account for species differences in initial seedling size and to compare shoot and root growth between species, absolute growth rates were calculated as the increase in seedling height or root length devided by the exposure period of the experiment (Paine et al. 2012). Absolute growth rates are appropriate to capture age- and size-dependent growth (i.e. initial seedling growth in our study) (Paine et al. 2012). Growth rates and seedling morphology data were log-transformed to achieve 
normality of residuals and homoscedasticity according to Shapiro-Wilks test (Shapiro.test, package 'stats') and Levenes test (leveneTest, package 'car'), respectively. Two-way factorial ANOVAs were conducted to compare the main effects of species and treatments and the interaction between species and treatments on the different morphological traits and growth rates. Tukey HSD tests allowed multiple comparisons between species and treatments (Anova and HSD.test, packages 'car' and 'agricolae', respectively). In cases of significant interaction effects, one-way ANOVAs with subsequent Tukey HSD tests were conducted to investigate significant differences between levels within the variables (species, treatment) separately. Where normality of residuals could not be achieved (for values of $\mathrm{E}_{\text {crit }}$ ), a Kruskal-Wallis test (kruskalmc, package 'pgirmess') was used for multiple comparisons of $E_{\text {crit }}$ between treatments and species. Statistical significance was based on a 0.05 probability level. A principal components analysis (PCA) was used to assess how parameters of seedling size and stability interrelate between species and treatments using the software CANOCO, version 5.02 (Biometris, the Netherlands).

\subsection{Results}

Growth of seedlings depending on waterlogging treatment

Shoot growth rates differed between the three species in all treatments with highest shoot growth rates for Elytrigia atherica and lowest shoot growth rates for Atriplex portulacoides ( $p<0.001$, Figs. $2.3 \&$ 2.4a). This resulted in substantial differences in seedling size at the end of the experiment. Seedlings of $E$. atherica ( $252 \mathrm{~mm}$ shoot height in the drained treatment) were 4 times and 8 times taller than those of Salicornia europaea $(75 \mathrm{~mm})$ and A. portulacoides $(34 \mathrm{~mm})$, respectively (Table 2.2, see also Table S2.1 for measurements of seedling height and Table S2.2 for results of two-way factorial ANOVAs). Absolute root growth rates in the drained treatment differed between the three species ( $p<0.001$, Fig. 2.4a). Root growth rates of E. atherica were significantly higher than those of $S$. europaea and A. portulacoides. Under waterlogged conditions there were no significant inter-specific differences. 


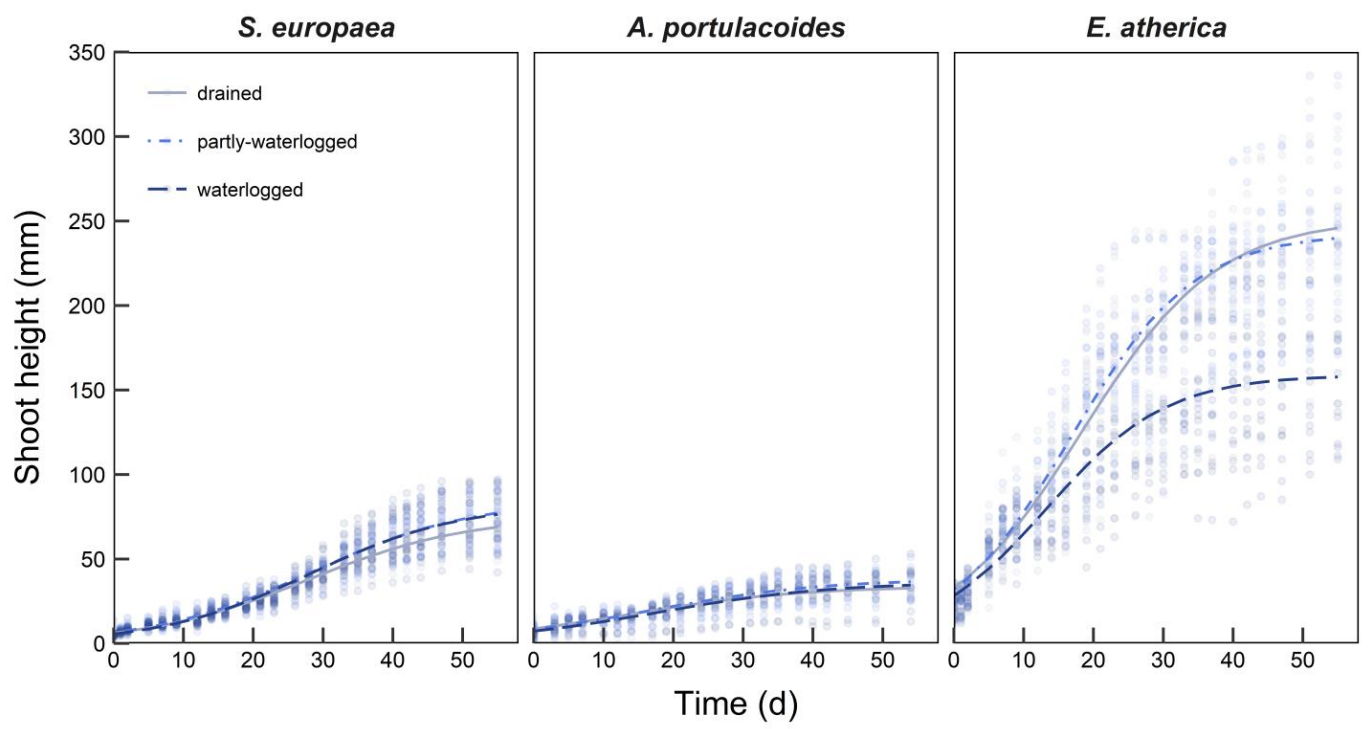

Figure 2.3: Growth of Salicornia europaea, Atriplex portulacoides and Elytrigia atherica seedlings during the experiment depending on waterlogging treatments. Dots represent measurements of individual seedlings; lines represent predictions of a three-parameter logistic model for the different treatments. Note overlaying lines under different treatments for S. europaea and A. portulacoides.

Table 2.2: Parameters of a three-parameter logistic model for the growth of Salicornia europaea, Atriplex portulacoides and Elytrigia atherica seedlings exposed to three waterlogging treatments. $\mathrm{H}_{0}$ : height at beginning of the experiment $(\mathrm{mm}), \mathrm{K}$ : shoot height at harvest $(\mathrm{mm})$; r: relative growth rate $\left(\mathrm{mm} \mathrm{mm}^{-1}\right.$ day $\left.^{-1}\right)$. Values for partly-waterlogged and waterlogged treatments are given as deviation from the drained treatment. Deviations were non-significant (restricted maximum likelihood test) except where shown: $p<0.05: *, p<$ $0.01: * *, p<0.001: * * *$.

\begin{tabular}{|c|c|c|c|c|}
\hline & $\mathrm{H}_{0} \pm \mathrm{SE}$ & $\mathbf{K} \pm \mathbf{S E}$ & $\mathbf{r} \pm \mathbf{S E}$ & Residuals \\
\hline \multicolumn{5}{|l|}{ S. europaea } \\
\hline drained & $6.2 \pm 0.5$ & $75.4 \pm 3.4$ & $0.0868 \pm 0.0030$ & 2.095 \\
\hline partly-waterlogged & $0.3 \pm 0.7$ & $9.7 \pm 4.9 *$ & $0.0003 \pm 0.0041$ & 2.095 \\
\hline waterlogged & $-0.6 \pm 0.7$ & $7.3 \pm 4.8$ & $0.0062 \pm 0.0041$ & 2.095 \\
\hline \multicolumn{5}{|l|}{ A. portulacoides } \\
\hline drained & $8.7 \pm 1.0$ & $34.0 \pm 3.0$ & $0.0797 \pm 0.0060$ & 1.855 \\
\hline partly-waterlogged & $-0.3 \pm 1.3$ & $4.4 \pm 4.1$ & $-0.0014 \pm 0.0079$ & 1.855 \\
\hline waterlogged & $-1.4 \pm 1.3$ & $2.3 \pm 4.2$ & $-0.0002 \pm 0.0080$ & 1.855 \\
\hline \multicolumn{5}{|l|}{ E. atherica } \\
\hline drained & $32.8 \pm 1.9$ & $251.5 \pm 10.3$ & $0.1031 \pm 0.0090$ & 10.966 \\
\hline partly-waterlogged & $-0.9 \pm 2.6$ & $-8.4 \pm 14.4$ & $0.0100 \pm 0.0122$ & 10.966 \\
\hline waterlogged & $-4.5 \pm 2.8$ & $-92.5 \pm 15.1 * * *$ & $0.0127 \pm 0.0132$ & 10.966 \\
\hline
\end{tabular}



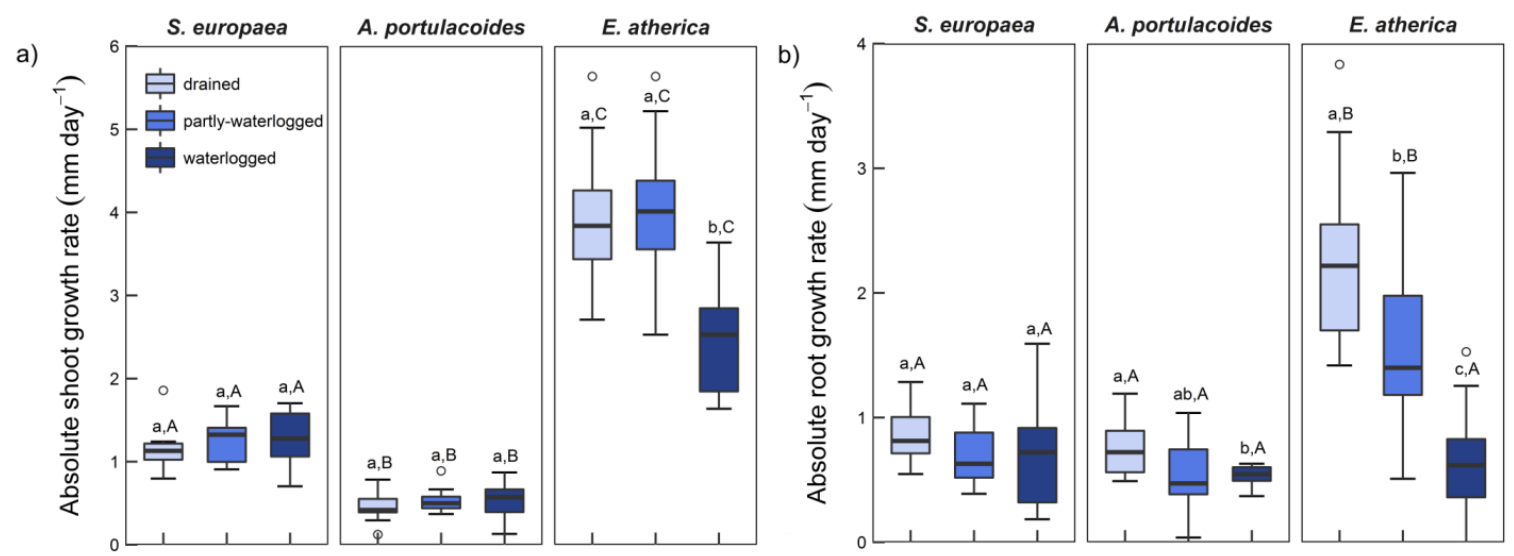

c)
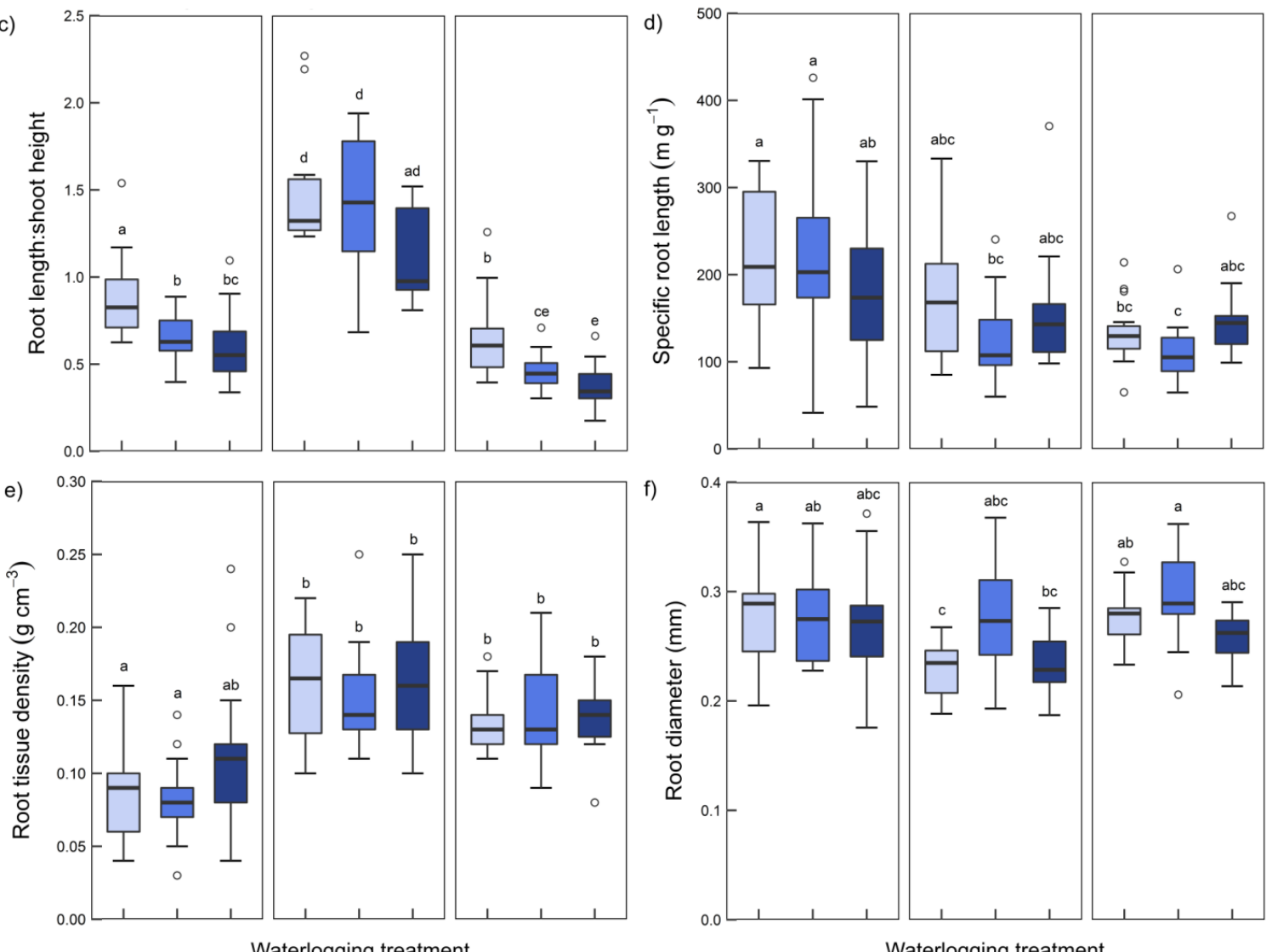

Figure 2.4: Root and shoot growth rates, and measures of root morphology for Salicornia europaea, Atriplex portulacoides and Elytrigia atherica seedlings grown under different waterlogging treatments (drained, partly waterlogged, waterlogged). Horizontal lines indicate median values, boxes the interquartile range, and error bars minimum and maximum values. Open circles represent outliers. Where the interaction was significant, different lower case letters indicate statistical differences between treatments within species, while different upper case letters mark significant differences between species within treatments according to one-way ANOVA with Tukey's HSD tests $(\mathrm{p}<0.05)$. Elsewhere, different lower case letters indicate significant differences comparing species and treatments by two-way factorial ANOVA with Tukey's HSD tests $(p<0.05)$. 
Seedling size at the end of the exposure period was affected significantly by waterlogging treatments within species for S. europaea and E. atherica. Performance of S. europaea seedlings was slightly better under partly-waterlogged and fully waterlogged conditions compared to the drained treatment. However, only the partly-waterlogged treatment led to a significant increase in shoot height $(21.5 \%)$ compared to the drained treatment $(p<0.05)$. E. atherica was affected negatively in its growth by waterlogging. Shoot height of seedlings was lower by $37 \%(p<0.001)$ in the waterlogged treatment compared to the drained treatment (three-parameter logistic growth model; Fig. 2.3 and Table 2.2). Absolute root growth rates of A. portulacoides and E. atherica were reduced by waterlogging treatments (Fig. 2.4b). Absolute root growth rate of A. portulacoides seedlings was reduced by $36 \%$ $(p<0.05)$ when waterlogged. This effect was also evident for E. atherica $(70 \%$ reduction of absolute root growth rate, $p<0.001)$. Root and shoot biomass showed similar patterns as shoot height and root length (Table S2.1).

\section{Effects of waterlogging on seedling morphology}

In the three species, root:shoot length ratios tended to decrease from the drained to the waterlogged treatment, although this trend was only significant for S. europaea (33\% decrease) and E. atherica (40\% decrease, $p<0.05$, Fig. 2.4c). Root:shoot length ratios differed between all three species in all treatments $(p<0.001)$ and were highest in A. portulacoides seedlings and lowest in E. atherica. The root morphological traits SRL, SRA, RTD and root diameter were not affected by the treatments (Fig. 2.4d-f, Table S2.1). S. europaea seedlings showed higher SRL and SRA and lower RTD under drained and partly-waterlogged conditions compared to the other species $(p<0.001)$.

\section{Effects of waterlogging on seedling stability}

A significant decrease of $E_{\text {crit }}$ from the drained to the waterlogged treatment was only found in $E$. atherica (80\% decrease, Kruskall-Wallis, $p<0.05$, Fig. 2.5). Furthermore, E. atherica seedlings from the drained and partly-waterlogged treatments showed a significantly higher $\mathrm{E}_{\text {crit }}$ compared to $S$. europaea and A. portulacoides within treatments. Under waterlogged conditions, critical erosion depth of E. atherica was similar to that of S. europaea and A. portulacoides. 


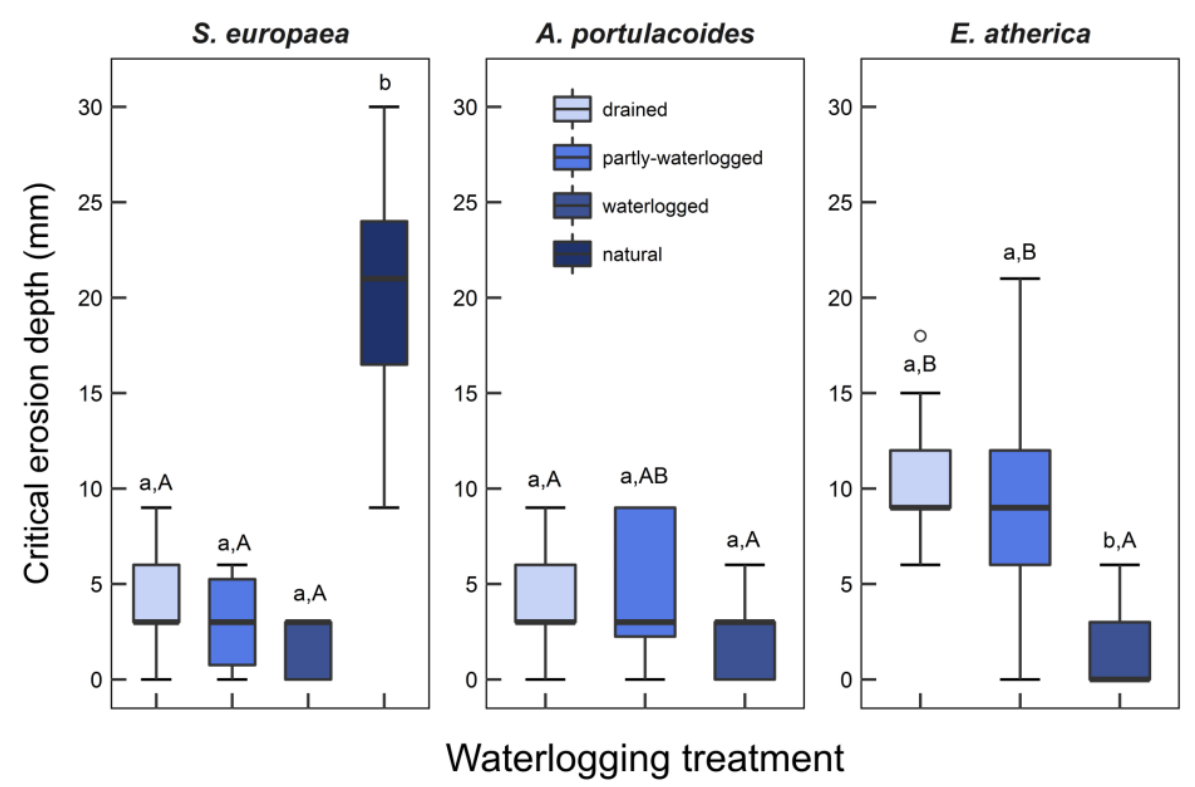

Figure 2.5: Critical erosion depth of Salicornia europaea, Atriplex portulacoides and Elytrigia atherica seedlings depending on sediment conditions in the greenhouse experiment and of Salicornia sp. seedlings grown under natural field conditions. Lower case letters mark statistically significant differences between treatments within species, upper case letters mark statistically significant differences between species within treatments (Kruskal-Wallis multiple comparisons, significance level $p<0.05$ ).

\section{Comparison with Salicornia seedlings from the tidal flat}

Salicornia sp. seedlings naturally established in the field showed significant differences compared to experimental plants. Although similar in shoot height (Table S2.1), they had higher root biomass, shoot biomass, root length and ratios of root:shoot biomass and length (one-way ANOVA with Tukey's HSD tests, $p<0.001$ in all cases, Table S2.1). SRL and SRA were lower $(p<0.001)$, whereas RTD $(p<0.05)$ and root diameter $(p<0.001)$ were higher compared to seedlings from the greenhouse. Critical erosion depth of naturally recruited seedlings was more than 5-fold higher compared to those grown in the experimental mesocosms (Fig. 2.5). Redox-potentials measured at the tidal flat, where seedlings were collected, were intermediate between the values of partly-waterlogged and waterlogged treatments in the experiment at shallow depth $(+87 \mathrm{mV}$ in upper $2.5 \mathrm{~cm})$, but more negative compared to the experimental pots in deeper sediment (approx. $-200 \mathrm{mV}$ at $10 \mathrm{~cm}$ ) (Table 1). Redox-potential in the vegetated saltmarsh zones was positive in the pioneer zone (approx. $+200 \mathrm{mV}$ ) and increased to highly oxidized conditions in the upper salt marsh (approx. $+400 \mathrm{mV}$ ). 


\section{Linking seedling morphology to stability of seedlings against erosion}

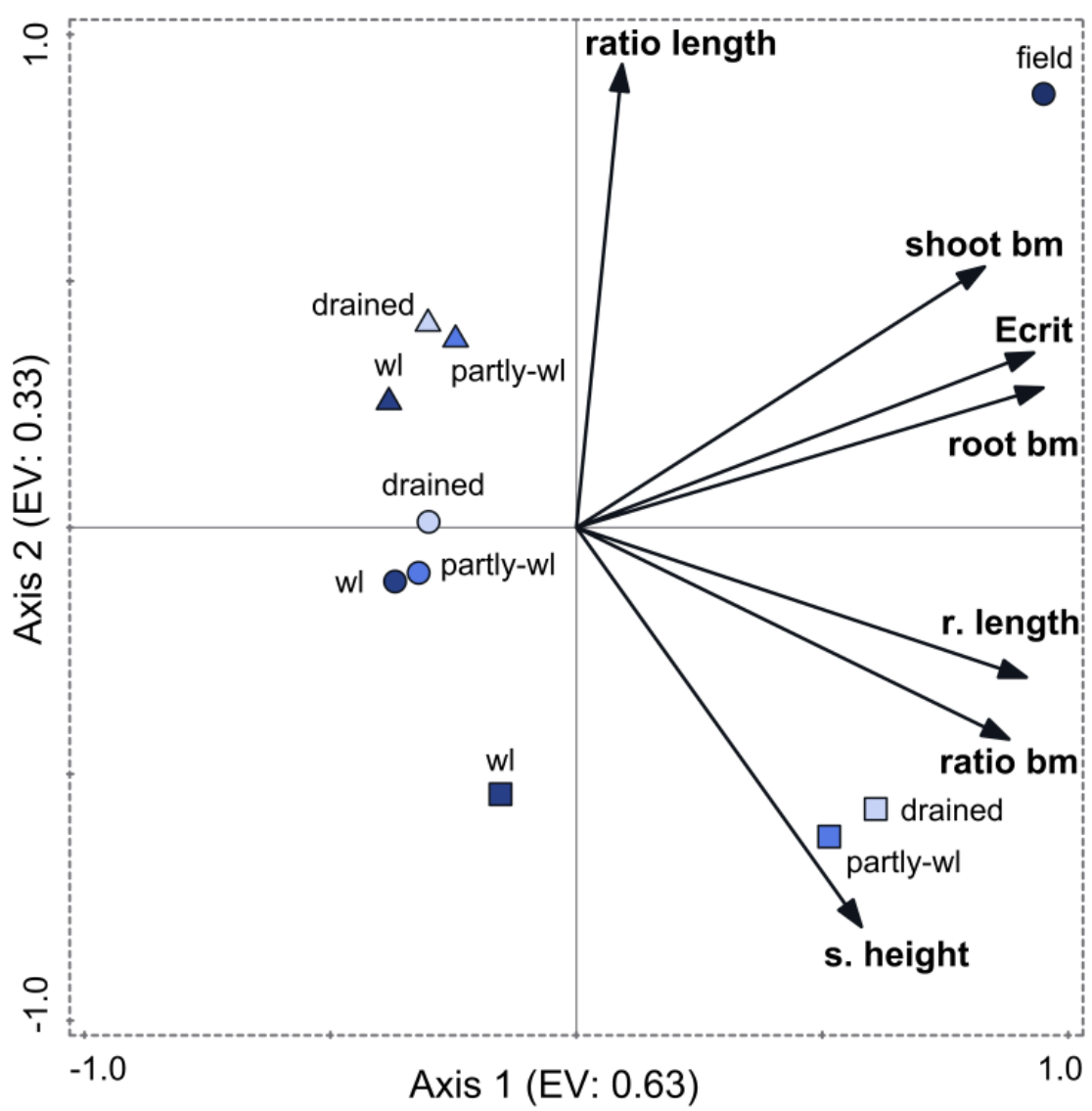

Figure 2.6: Results of Principal components analysis (PCA) of factors influencing seedling stability in response to erosion for Atriplex portulacoides (triangle), Salicornia spp. (circle), and Elytrigia atherica (square). Seedlings were subjected to three treatments: drained, partly waterlogged (partly-wl) and completely waterlogged (wl); in addition seedlings of Salicornia spp. were grown under natural field conditions. Factors considered in the analysis included measures of seedling size and the critical erosion depth $\left(\mathrm{E}_{\text {crit }}\right)$ determined for each species under different conditions (see Fig. 2.5). For detailed results of the PCA see Table S2.3). Abbreviations: r.length: root length; s.height: shoot height; root bm: root biomass; shoot bm: shoot biomass; ratio length: ratio of root length to shoot length; ratio bm: ratio of root biomass to shoot biomass; EV: eigenvalues.

In the Principal Components Analysis (PCA, Fig. 2.6, Table S2.3), critical erosion depth was strongly positively associated with the first axis (eigenvalue 0.63 ) together with root length and biomass as well as shoot biomass and the ratio in root:shoot biomass. Furthermore, shoot height was strongly negatively associated with the second axis (eigenvalue 0.33), while the ratio in root length: shoot height was positively associated with this axis. The PCA plot in Fig. 2.6 indicates that S. europaea 
and A. portulacoides seedlings resembled each other in terms of seedling size and stability in all three treatments, while the drained and the partly-waterlogged treatment formed a cluster separated from the waterlogged treatment in the case of E. atherica. Salicornia sp. seedlings grown under natural field conditions did not group with any of the treatments of $S$. europaea in the greenhouse or with the other two species.

\subsection{Discussion}

Seedling establishment is a critical phase in plant ontogeny, especially in frequently disturbed ecosystems such as salt marshes, mangroves and riparian forests. Short-term sediment erosion during inundation can excavate and dislodge seedlings; rapid root anchorage is thus crucial for seedling survival in these environments. Understanding bottlenecks for vegetation establishment is particularly important when attempting restoration of tidal wetlands, which are increasingly acknowledged for their ecosystem services. Our study demonstrates that waterlogged soil conditions may inhibit root growth of saltmarsh seedlings, leading to decreased resistance of seedlings against physical disturbance. The strongest negative effect of waterlogging was found for the upper saltmarsh species Elytrigia atherica. While seedlings from E. atherica grew fastest throughout the experiment under drained conditions, they were most susceptible to waterlogging (Figs 3 to 5). This result supports previous findings that Elytrigia atherica is a highly competitive species, but very sensitive to waterlogging (Armstrong et al. 1985; Schröder et al. 2002; Veeneklaas et al. 2013). Along the NW European North Sea coast, E. atherica spreads rapidly in many sites frequently forming monospecific stands at the rarely inundated upper salt marsh (Bockelmann and Neuhaus 1999; Stock et al. 2005). Rhizomes of E. atherica can spread rapidly and locally outcompete other species, but successful seedling establishment is still necessary for reproduction over larger distances (Veeneklaas 2013). Our study indicates that successful establishment of E. atherica seedlings on tidal flats may be limited by a strong inhibition of root growth and the resulting decreased stability of seedlings during erosion events. In the upper salt marsh however, E. atherica is able to outcompete Salicornia spp. and Atriplex portulacoides due to its rapid root and shoot growth under drained conditions.

Bockelmann and Neuhaus (1999) investigated competition between E. atherica and A. portulacoides and concluded that E. atherica is excluded from the lower salt marsh due to competition with $A$. portulacoides rather than by abiotic factors. Our study suggests that E. atherica may also be disadvantaged at frequently flooded sites in the absence of competition due to a higher sensitivity to waterlogging at the seedling stage. This may be especially important where newly available habitats are colonized by saltmarsh plants (Balke et al. 2017). 
In contrast to the strong negative impact of waterlogging on E. atherica, S. europaea and A. portulacoides were hardly affected in their growth by the waterlogging treatments. Shoot height of $S$. europaea was even higher under partly-waterlogged conditions compared to the drained treatment (Fig. 2.3, Table 2.2), indicating the good adaptation of this species to waterlogged conditions on tidal flats. Although root growth of $A$. portulacoides was reduced under waterlogged conditions, there was no difference between seedling stability of $S$. europaea and A. portulacoides. Thus, further abiotic and biotic components and their interactions need to be considered when explaining niche separation across the saltmarsh gradient, such as salinity tolerance (Cooper 1982; Rozema et al. 1983; Armstrong et al. 1985; Rozema et al. 1985; Redondo-Gómez et al. 2007; Katschnig et al. 2013), interspecific competition (Huckle et al. 2000; Balke et al. 2017), or herbivory (He et al. 2015).

Frequent inundation and accompanying strongly reduced soil conditions as simulated in our experiment are especially common on bare tidal flats suitable for new colonization, but also in the lowest elevations of the salt marsh. Anoxia persists in this zone throughout the growing season even in the upper centimeters of the sediment (Table 2.1, Armstrong et al. 1985). All treatments of our experiment had lower redox-potentials compared to field measurements in the salt marsh (including the pioneer zone), whereas sediment of the tidal flat was overall more reduced than the partlywaterlogged and drained treatments. In Davy et al.'s (2011) study on the relationship of species distributions and redox-potential, Salicornia europaea was found to tolerate redox-potentials of less than $-100 \mathrm{mV}$, A. portulacoides was absent in plots below a threshold of $+100 \mathrm{mV}$ and E. atherica was absent below $+200 \mathrm{mV}$. Comparing these thresholds to the values measured in our experimental treatments shows that seedlings in the experimental pots were subjected to extremely reduced conditions below the limits in their natural habitats (Table 2.1). However, seedlings of all three species not only were able to survive these extreme conditions but also showed treatment-dependent effects. This suggests an effect of anoxia on seedling development that may also depend on site (e.g. sediment type, salinity, wave exposure) and life stage (e.g. isolated seedling, adult plant in competition with other species). Relatively small differences in redox-potential between treatments in deeper sediment layers, despite the differences in water level of the sediment, indicate that a less negative redox-potential in the upper sediment layers is already sufficient for the seedlings to establish roots which are strong enough to withstand erosion.

Unexpectedly, waterlogging treatments had no with-species effects on root morphology. This indicates that these herbaceous and grass species do not adjust their root morphology under changing environmental conditions as found for example for tree species (Eissenstat et al. 2000; Ostonen et al. 2007; Vanguelova et al. 2007). S. europaea had significantly higher SRL and SRA and lower RTD compared to E. atherica and A. portulacoides in the drained and the partly-waterlogged treatments. 
This is consistent with findings that roots with shorter lifespan have lower RTD (Ryser 1996) and higher SRL and therefore make relatively small investments in structural carbon (Eissenstat et al. 2000). Annual plants, such as $S$. europaea, are typical examples. Moreover, the tap root system of $S$. europaea and A. portulacoides may have advantages for plant stability compared to the fibrous root system of E. atherica, as common for monocotyledons. The fibrous root system may also explain the strong competitive abilities of $E$. atherica since it provides better opportunities for resource exploitation. However, from the roots at the seedling stage (i.e. time of harvest in our experiment) differences in root structure could not be observed between species (recognized in the WinRhizo images, not shown). We therefore conclude that these differences in root structure do not yet play a role at the early seedling phase and may only become important during later development stages.

We found substantial differences between naturally recruited seedlings and those grown in the greenhouse experiment. Although similar shoot heights were chosen, seedlings from the tidal flat showed significantly higher stability, which may be related to a higher root length (Figs $5 \& 6$, Tables S1 \& S3), and possibly also to the already well-developed tap root (WinRhizo images) which the experimental seedlings were still lacking. Field material was harvested in late June and hence approximately 2-3 months after germination in March to April (i.e. they were approximately of same age as the experimental seedlings). Differences between field and greenhouse-grown plants have been observed in various ecosystems e.g. for germination rates (Elberse and Breman 1990), photosynthetic induction (Zotz and Mikona 2003) or salt tolerance in Salicornia spp. (Riehl and Ungar 1982). This asks for caution when interpreting data from laboratory studies. In our study, differences between field and experimental seedlings indicate that permanently acting mechanical stress from wind and waves, which was not simulated in the greenhouse, may lead to important plastic morphological responses (i.e. thigmomorphogenesis; (Jaffe 1973; Chehab et al. 2009)). Increased root allocation of field grown seedlings by thigmomorphogenesis increases their resistance to mechanical perturbation ('tolerance strategy', Puijalon et al. 2011) and has been observed by other authors in aquatic (Puijalon and Bornette 2006) and terrestrial (Crook and Ennos 1996; Goodman and Ennos 1996) plants as a response to mechanical stimulation. In addition, lower light levels in the greenhouse may have affected growth rates and seedling morphology in relation to surveyed seedlings in the field. Pennings et al. (2005) conducted field and greenhouse experiments with Juncus roemerianus and made similar observations: biomass was much higher in individuals grown in the field than in those grown in the greenhouse, but the response of seedlings to various flooding and salinity treatments was highly correlated between field and glasshouse. Thus, we conclude that the results of our mesocosm experiment are of ecological relevance, especially when comparing the three species grown under same, controlled conditions in the greenhouse among each other. However, this study highlights that 
the effects of thigmomorphogenesis for seedling stability may also play a role in seedling establishment on tidal flats and requires further experimental investigation.

The close relationship between the critical erosion depth of seedlings grown in the experimental mesocosms and seedling traits such as root and shoot biomass and length (Fig. 2.6, Table S2.3) may also be relevant to other plant species in biogeomorphic ecosystems (i.e. mangroves, riparian vegetation or seagrass beds). Rapid root growth of seedlings in their first weeks of development is crucial for their tolerance against physical disturbance in these habitats. It is known that several intertidal wetland pioneer species (i.e. Salicornia spp., Spartina spp. and Avicennia spp.) show rapid root emergence and development (Friess et al. 2012). With rapid root growth, saltmarsh and mangrove pioneers are able to utilize disturbance free Windows of Opportunity to gain tolerance against subsequent disturbance by inundation, wave action and short-term sediment erosion (Balke et al. 2011; Balke et al. 2014; Cao et al. 2017). The present study showed that seedling stability within the first weeks after emergence can be severely limited by soil waterlogging through reduced root growth.

\section{Conclusions}

Our study showed that waterlogged and anoxic soil conditions can eliminate species-specific differences in root growth and tolerance of seedlings against erosion that otherwise exist in drained conditions. Niche separation in salt marshes may thus not only be attributed to tolerance of salt and inundation stress or competitive strength, since tolerance against physical disturbance at the seedling stage may be strongly influenced by soil waterlogging. This interaction could be demonstrated for the upper saltmarsh species Elytrigia atherica in our study and may be one determinant for the distribution of this species across the elevational saltmarsh gradient. Further studies are suggested across frequently disturbed and inundated ecosystems (mangroves, riparian forests, seagrass beds) to investigate the effects of soil anoxia on plant traits and stability, and the spatial relationship between exposure to disturbance and soil anoxia of suitable habitats for colonization. This is especially important to improve restoration success in coastal wetland ecosystems.

\section{Acknowledgements}

A special thanks to the team of the Institue for Chemistry and Biology of the Marine Environment (ICBM, University of Oldenburg) mechanical workshop for help with the setup of the experiment. Dr. Robert Fischer (Oldenburg) helped during the experiment and Roman Link (Göttingen) gave statistical advice. This work was part of the joint research project 'Biodiversity and Ecosystem 
Functioning across marine and terrestrial ecosystems' (BEFmate) funded by the Ministry for Science and Culture of Lower Saxony, Germany (project number ZN2930). 


\subsection{Supplementary Material}

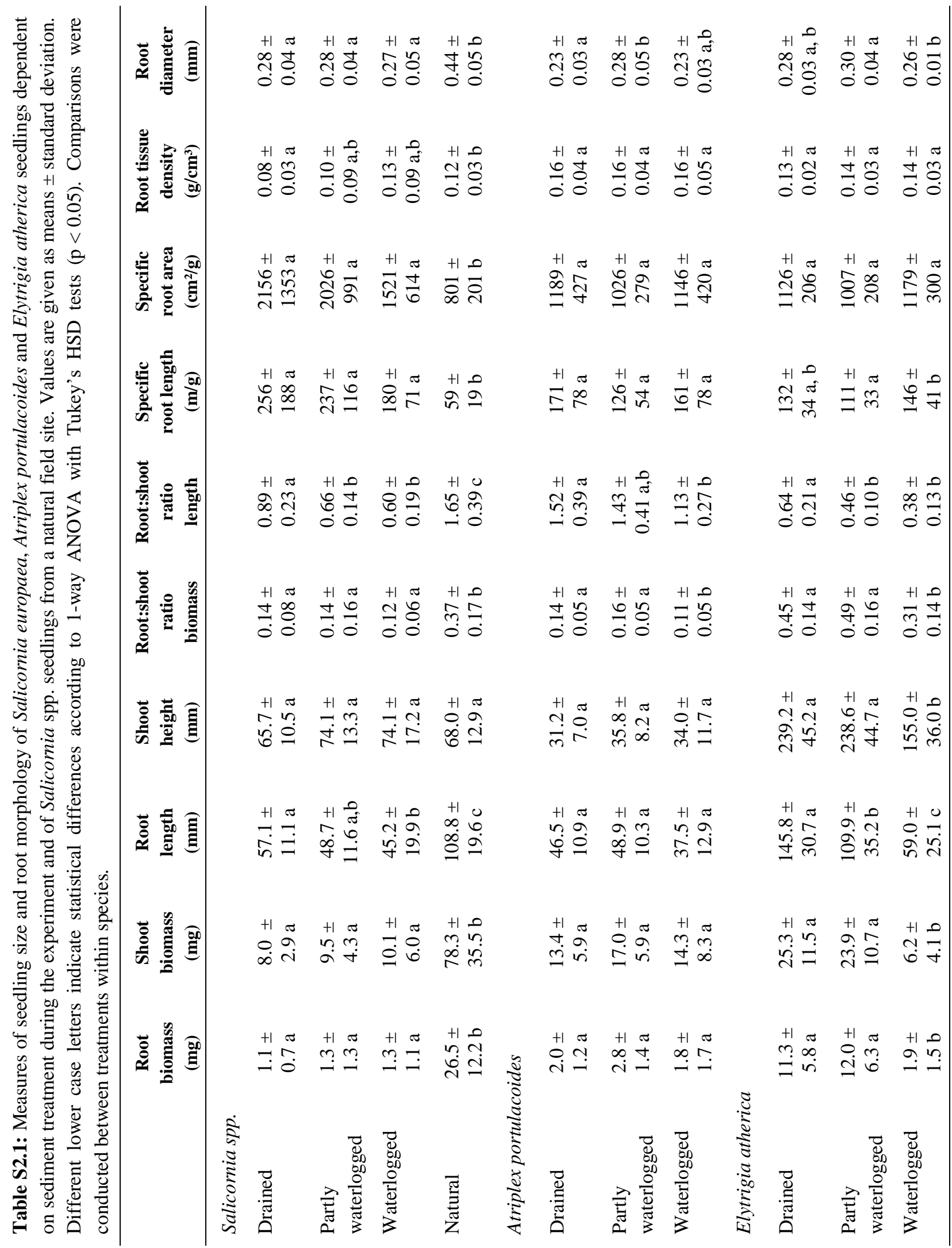


Table S2.2: Two-way factorial ANOVA with effects of species and treatment for measures of seedling size and root morphology of Salicornia europaea, Atriplex portulacoides and Elytrigia atherica seedlings exposed to three different sediment treatments (drained, partly-waterlogged, waterlogged) over 47 to 55 days.

\begin{tabular}{|c|c|c|c|c|c|}
\hline Variable & Source of variation & Type III SS & df & F-value & Sig. \\
\hline \multicolumn{6}{|l|}{ Root length } \\
\hline & Species & 11.50 & 2 & 56.52 & $* * *$ \\
\hline & Treatment & 0.62 & 2 & 3.06 & \\
\hline & Species x Treatment & 2.60 & 4 & 6.39 & $* * *$ \\
\hline & Residuals & 13.12 & 129 & & \\
\hline \multicolumn{6}{|l|}{ Shoot height } \\
\hline & Species & 30.18 & 2 & 291.67 & $* * *$ \\
\hline & Treatment & 0.18 & 2 & 1.04 & \\
\hline & Species x Treatment & 1.55 & 4 & 7.48 & $* * *$ \\
\hline & Residuals & 6.67 & 129 & & \\
\hline \multicolumn{6}{|c|}{ Root biomass } \\
\hline & Species & 55.12 & 2 & 44.99 & $* * *$ \\
\hline & Treatment & 2.77 & 2 & 2.26 & \\
\hline & Species $\mathrm{x}$ Treatment & 22.38 & 4 & 9.13 & $* * *$ \\
\hline & Residuals & 79.03 & 129 & & \\
\hline \multicolumn{6}{|c|}{ Shoot biomass } \\
\hline & Species & 11.65 & 2 & 20.31 & $* * *$ \\
\hline & Treatment & 0.65 & 2 & 1.13 & \\
\hline & Species x Treatment & 15.05 & 4 & 13.12 & $* * *$ \\
\hline & Residuals & 37.00 & 129 & & \\
\hline \multicolumn{6}{|c|}{ Ratio root:shoot length } \\
\hline & Species & 5.12 & 2 & 35.26 & $* * *$ \\
\hline & Treatment & 0.51 & 2 & 3.50 & $*$ \\
\hline & Species x Treatment & 0.27 & 4 & 0.92 & \\
\hline & Residuals & 9.37 & 129 & & \\
\hline \multicolumn{6}{|c|}{ Ratio root:shoot biomass } \\
\hline & Species & 16.80 & 2 & 38.73 & $* * *$ \\
\hline & Treatment & 0.86 & 2 & 1.98 & \\
\hline & Species $x$ Treatment & 1.10 & 4 & 1.27 & \\
\hline & Residuals & 27.97 & 129 & & \\
\hline \multicolumn{6}{|c|}{ Specific root area } \\
\hline & Species & 3.23 & 2 & 11.79 & $* * *$ \\
\hline & Treatment & 0.09 & 2 & 0.34 & \\
\hline & Species $\mathrm{x}$ Treatment & 0.96 & 4 & 1.74 & \\
\hline & Residuals & 17.67 & 129 & & \\
\hline \multicolumn{6}{|c|}{ Specific root length } \\
\hline & Species & 2.69 & 2 & 7.83 & $* * *$ \\
\hline & Treatment & 0.56 & 2 & 1.63 & \\
\hline & Species x Treatment & 1.50 & 4 & 2.19 & \\
\hline & Residuals & 22.16 & 129 & & \\
\hline
\end{tabular}




\begin{tabular}{cccccc}
\hline Variable & $\begin{array}{c}\text { Source of } \\
\text { variation }\end{array}$ & Type III SS & df & F-value & Sig. \\
\hline Root tissue density & Species & 4.64 & 2 & 15.51 & $* * *$ \\
& Treatment & 0.01 & 2 & 0.04 & \\
& Species x & 0.73 & 4 & 1.23 & \\
& Treatment & & & & \\
& Residuals & 19.28 & 129 & & $* *$ \\
& Species & 0.28 & 2 & 6.88 & $* *$ \\
& Treatment & 0.20 & 2 & 4.88 & \\
& Species $x$ & 0.14 & 4 & 1.75 & \\
& Treatment & & & & \\
& Residuals & 2.62 & 129 & & \\
\hline
\end{tabular}

$p<0.05: *, p<0.01: * *, p<0.001: * * *$

Table S2.3: Results of a Principal Components Analysis (PCA) regarding the critical erosion depth of seedlings and different measures of seedling size. Given are the loadings of the selected variables along the four main explanatory axes as well as the cumulative $\mathrm{r}^{2}$ values (in brackets) for a given variable. Numbers below the four axes indicate the eigenvalues (EV) of the axes. Numbers in bold indicate the variables with the closest relation to the respective axis. Axis 3 and 4 are not given due to their low explanation of variance.

\begin{tabular}{lcc}
\hline & Axis 1 & Axis 2 \\
& EV 0.63 & EV 0.33 \\
\hline Critical erosion depth & $\mathbf{0 . 9 3}(0.86)$ & $0.35(0.99)$ \\
Root length & $\mathbf{0 . 9 1}(0.84)$ & $-0.30(0.92)$ \\
Shoot height & $0.58(0.34)$ & $\mathbf{- 0 . 8 1}(0.99)$ \\
Root:shoot ratio in length & $0.09(0.01)$ & $\mathbf{0 . 9 4}(0.89)$ \\
Root biomass & $\mathbf{0 . 9 5}(0.90)$ & $0.28(0.98)$ \\
Shoot biomass & $\mathbf{0 . 8 3}(0.69)$ & $\mathbf{0 . 5 3}(0.97)$ \\
Root:shoot ratio in biomass & $\mathbf{0 . 8 8}(0.77)$ & $-0.43(0.96)$ \\
\hline
\end{tabular}




\section{References}

Armstrong W, Wright EJ, Lythe S, Gaynard TJ (1985) Plant zonation and the effects of the springneap tidal cycle on soil aeration in a humber salt-marsh. Journal of Ecology 73:323-339.

Balke T, Bouma TJ, Horstman EM, Webb EL, Erftemeijer PL, Herman PM (2011) Windows of opportunity: thresholds to mangrove seedling establishment on tidal flats. Marine Ecology Progress Series 440:1-9. doi:10.3354/meps09364.

Balke T, Herman PMJ, Bouma TJ (2014) Critical transitions in disturbance-driven ecosystems: identifying Windows of Opportunity for recovery. Journal of Ecology 102:700-708. doi:10.1111/1365-2745.12241.

Balke T, Lõhmus K, Hillebrand H, Zielinski O, Haynert K, Meier D, Hodapp D, Minden V, Kleyer M (2017) Experimental salt marsh islands: A model system for novel metacommunity experiments. Estuarine, Coastal and Shelf Science 198:288-298. doi:10.1016/j.ecss.2017.09.021.

Balke T, Stock M, Jensen K, Bouma TJ, Kleyer M (2016) A global analysis of the seaward salt marsh extent: The importance of tidal range. Water Resources Research 52:3775-3786. doi:10.1002/2015WR018318.

Balke T, Webb EL, van den Elzen E, Galli D, Herman PMJ, Bouma TJ (2013) Seedling establishment in a dynamic sedimentary environment: a conceptual framework using mangroves. The Journal of Applied Ecology 50:740-747. doi:10.1111/1365-2664.12067.

Bertness MD, Ellison AM (1987) Determinants of pattern in a New-England salt-marsh plant community. Ecological Monographs 57:129-147.

Bockelmann AC, Bakker JP, Neuhaus R, Lage J (2002) The relation between vegetation zonation, elevation and inundation frequency in a Wadden Sea salt marsh. Aquatic Botany 73:211-221. doi:10.1016/S0304-3770(02)00022-0.

Bockelmann AC, Neuhaus R (1999) Competitive exclusion of Elymus athericus from a high-stress habitat in a European salt marsh. Journal of Ecology 87:503-513.

Bouma TJ, Koutstaal BP, van Dongen M, Nielsen KL (2001) Coping with low nutrient availability and inundation: root growth responses of three halophytic grass species from different elevations along a flooding gradient. Oecologia 126:472-481. doi:10.1007/s004420000545.

Bouma TJ, van Belzen J, Balke T, van Dalen J, Klaassen P, Hartog AM, Callaghan DP, Hu Z, Stive MJF, Temmerman S, Herman PMJ (2016) Short-term mudflat dynamics drive long-term cyclic salt marsh dynamics. Limnology and Oceanography 61:2261-2275. doi:10.1002/lno.10374.

Cao H, Zhu Z, Balke T, Zhang L, Bouma TJ (2017) Effects of sediment disturbance regimes on Spartina seedling establishment: Implications for salt marsh creation and restoration. Limnology and Oceanography. doi:10.1002/lno.10657.

Chehab EW, Eich E, Braam J (2009) Thigmomorphogenesis: a complex plant response to mechanostimulation. Journal of Experimental Botany 60:43-56. doi:10.1093/jxb/ern315. 
Clarke LD, Hannon NJ (1970) The mangrove swamp and salt marsh communities of the Sydney district: III. Plant growth in relation to salinity and waterlogging. Journal of Ecology 58:351-369.

Cooper A (1982) The effects of salinity and waterlogging on the growth and cation uptake of salt marsh plants. New Phytologist 90:263-275.

Corenblit D, Baas AC, Balke T, Bouma TJ, Fromard F, Garófano-Gómez V, González E, Gurnell AM, Hortobágyi B, Julien F, Kim D, Lambs L, Stallins JA, Steiger J, Tabacchi E, Walcker R (2015) Engineer pioneer plants respond to and affect geomorphic constraints similarly along water-terrestrial interfaces world-wide. Global Ecology and Biogeography 24:1363-1376. doi:10.1111/geb.12373.

Corenblit D, Tabacchi E, Steiger J, Gurnell AM (2007) Reciprocal interactions and adjustments between fluvial landforms and vegetation dynamics in river corridors. A review of complementary approaches. Earth-Science Reviews 84:56-86. doi:10.1016/j.earscirev.2007.05.004.

Crain CM, Silliman BR, Bertness SL, Bertness MD (2004) Physical and biotic drivers of plant distribution across estuarine salinity gradients. Ecology 85:2539-2549.

Crook MJ, Ennos AR (1996) Mechanical differences between free-standing and supported wheat plants, Triticum aestivum L. Annals of Botany 77:197-202.

Davy AJ, Brown MJH, Mossman HL, Grant A (2011) Colonization of a newly developing salt marsh: disentangling independent effects of elevation and redox potential on halophytes. Journal of Ecology 99:1350-1357. doi:10.1111/j.1365-2745.2011.01870.x.

Eissenstat DM, Wells CE, Yanai RD, Whitbeck JL (2000) Building roots in a changing environment: implications for root longevity. New Phytologist 147:33-42.

Elberse WT, Breman H (1990) Germination and establishment of Sahelian rangeland species. II. Effects of water availability. Oecologia 85:32-40. doi:10.1007/BF00317340.

Ewanchuk PJ, Bertness MD (2004) Structure and organization of a northern New England salt marsh plant community. Journal of Ecology 92:72-85.

Fariña JM, Silliman BR, Bertness MD (2009) Can conservation biologists rely on established community structure rules to manage novel systems? ... Not in salt marshes. Ecological Applications 19:413-422.

Friess DA, Krauss KW, Horstman EM, Balke T, Bouma TJ, Galli D, Webb EL (2012) Are all intertidal wetlands naturally created equal? Bottlenecks, thresholds and knowledge gaps to mangrove and saltmarsh ecosystems. Biological reviews of the Cambridge Philosophical Society 87:346-366. doi:10.1111/j.1469-185X.2011.00198.x.

Goodman AM, Ennos AR (1996) A comparative study of the response of the roots and shoots of sunflower and maize to mechanical stimulation. Journal of Experimental Botany 47:1499-1507.

Grubb PJ (1977) The maintenance of species-richness in plant communities: the importance of the regeneration niche. Biological reviews of the Cambridge Philosophical Society 52:107-145. 
Han Q, Bouma TJ, Brun FG, Suykerbuyk W, van Katwijk MM (2012) Resilience of Zostera noltii to burial or erosion disturbances. Marine Ecology Progress Series 449:133-143. doi:10.3354/meps09532.

Havill DC, Ingold A, Pearson J (1985) Sulphide tolerance in coastal halophytes. Vegetatio 62:279285.

He Q, Altieri AH, Cui B (2015) Herbivory drives zonation of stress-tolerant marsh plants. Ecology 96:1318-1328. doi:10.1890/14-0937.1.

Hu Z, Lenting W, van der Wal D, Bouma TJ (2015) Continuous monitoring bed-level dynamics on an intertidal flat: Introducing novel, stand-alone high-resolution SED-sensors. Geomorphology 245:223-230. doi:10.1016/j.geomorph.2015.05.027.

Hu Z, Yao P, van der Wal D, Bouma TJ (2017) Patterns and drivers of daily bed-level dynamics on two tidal flats with contrasting wave exposure. Scientific Reports 7:7088. doi:10.1038/s41598017-07515-y.

Huckle JM, Potter JA, Marrs RH (2000) Influence of environmental factors on the growth and interactions between salt marsh plants: effects of salinity, sediment and waterlogging. Journal of Ecology 88:492-505.

Jaffe MJ (1973) Thigmomorphogenesis: The response of plant growth and development to mechanical stimulation. With special reference to Bryonia dioica. Planta 114:143-157. doi:10.1007/BF00387472.

Kadereit G, Piirainen M, Lambinon J, Vanderpoorten M (2012) Cryptic taxa should have names: Reflections in the glasswort genus Salicornia (Amaranthaceae). Taxon 61:1227-1239.

Katschnig D, Broekman R, Rozema J (2013) Salt tolerance in the halophyte Salicornia dolichostachya Moss: Growth, morphology and physiology. Environmental and Experimental Botany 92:32-42. doi:10.1016/j.envexpbot.2012.04.002.

Lamers LPM, Govers LL, Janssen ICJM, Geurts JJM, van der Welle MEW, van Katwijk MM, van der Heide T, Roelofs JGM, Smolders AJP (2013) Sulfide as a soil phytotoxin-a review. Frontiers in Plant Science 4:268. doi:10.3389/fpls.2013.00268.

Levine JM, Brewer JS, Bertness MD (1998) Nutrients, competition and plant zonation in a New England salt marsh. Journal of Ecology 86:285-292.

Mahoney JM, Rood SB (1998) Streamflow requirements for cottonwood seedling recruitment - An integrative model. Wetlands 18:634-645.

Moore KA, Orth RJ, Nowak JF (1993) Environmental regulation of seed-germination in Zostera marina L (Eelgrass) in Chesapeake Bay - effects of light, oxygen and sediment burial. Aquatic Botany 45:79-91.

Noe GB, Zedler JB (2000) Differential effects of four abiotic factors on the germination of salt marsh annuals. American Journal of Botany 87:1679-1692. doi:10.2307/2656745. 
Noe GB, Zedler JB (2001) Spatio-temporal variation of salt marsh seedling establishment in relation to the abiotic and biotic environment. Journal of Vegetation Science 12:61-74. doi: $10.2307 / 3236674$.

Ostonen I, Püttsepp Ü, Biel C, Alberton O, Bakker MR, Lõhmus K, Majdi H, Metcalfe D, Olsthoorn AFM, Pronk A, Vanguelova E, Weih M, Brunner I (2007) Specific root length as an indicator of environmental change. Plant Biosystems 141:426-442. doi:10.1080/11263500701626069.

Paine CET, Marthews TR, Vogt DR, Purves D, Rees M, Hector A, Turnbull LA (2012) How to fit nonlinear plant growth models and calculate growth rates. An update for ecologists. Methods in Ecology and Evolution 3:245-256. doi:10.1111/j.2041-210X.2011.00155.x.

Pennings SC, Callaway RM (1992) Salt-marsh plant zonation - The relative importance of competition and physical factors. Ecology 73:681-690.

Pennings SC, Grant M-B, Bertness MD (2005) Plant zonation in low-latitude salt marshes. Disentangling the roles of flooding, salinity and competition. Journal of Ecology 93:159-167. doi:10.1111/j.1365-2745.2004.00959.x.

Pennings SC, Moore DJ (2001) Zonation of shrubs in western Atlantic salt marshes. Oecologia 126:587-594.

Plus M, Deslous-Paoli JM, Dagault F (2003) Seagrass (Zostera marina L.) bed recolonisation after anoxia-induced full mortality. Aquatic Botany 77:121-134. doi:10.1016/S0304-3770(03)00089-5.

Puijalon S, Bornette G (2006) Phenotypic plasticity and mechanical stress: biomass partitioning and clonal growth of an aquatic plant species. American Journal of Botany 93:1090-1099.

Puijalon S, Bouma TJ, Douady CJ, van Groenendael J, Anten NPR, Martel E, Bornette G (2011) Plant resistance to mechanical stress: evidence of an avoidance-tolerance trade-off. New Phytologist 191:1141-1149. doi:10.1111/j.1469-8137.2011.03763.x.

R Development Core Team (2016) R: A Language and Environment for Statistical Computing. R Foundation for Statistical Computing, Vienna, Austria, https://www.R-project.org/.

Rand TA (2000) Seed dispersal, habitat suitability and the distribution of halophytes across a salt marsh tidal gradient. Journal of Ecology 88:608-621. doi:10.1046/j.1365-2745.2000.00484.x.

Redelstein R, Dinter T, Hertel D, Leuschner C (2018) Effects of Inundation, Nutrient Availability and Plant Species Diversity on Fine Root Mass and Morphology Across a Saltmarsh Flooding Gradient. Frontiers in Plant Science 9:98. doi:10.3389/fpls.2018.00098.

Redondo-Gómez S, Mateos-Naranjo E, Davy AJ, Fernandez-Munoz F, Castellanos EM, Luque T, Figueroa ME (2007) Growth and photosynthetic responses to salinity of the salt-marsh shrub Atriplex portulacoides. Annals of Botany 100:555-563. doi:10.1093/aob/mcm119.

Riehl TE, Ungar IA (1982) Growth and ion accumulation in Salicornia europaea under saline field conditions. Oecologia 54:193-199. doi:10.1007/BF00378392.

Rozema J, Bijwaard P, Prast G, Broekman R (1985) Ecophysiological adaptations of coastal halophytes from foredunes and salt marshes. Vegetatio 62:499-521. 
Rozema J, Vanmanen Y, Vugts HF, Leusink A (1983) Airborne and soilborne salinity and the distribution of coastal and inland species of the genus Elytrigia. Acta botanica Neerlandica 32:447-456.

Ryser P (1996) The importance of tissue density for growth and life span of leaves and roots: A comparison of five ecologically contrasting grasses. Functional Ecology 10:717-723.

Schröder HK, Kiehl K, Stock M (2002) Directional and non-directional vegetation changes in a temperate salt marsh in relation to biotic and abiotic factors. Applied Vegetation Science 5:33-44. doi:10.1658/1402-2001(2002)005[0033:DANDVC]2.0.CO;2.

Segelquist CA, Scott ML, Auble GT (1993) Establishment of Populus deltoides under simulated alluvial groundwater declines. The American Midland Naturalist 130:274-285. doi:10.2307/2426127.

Stock M, Gettner M, Hagge H, Heinzel K, Kohlus J, Stumpe H (2005) Salzwiesen an der Westküste von Schleswig-Holstein 1998 - 2001, Vol 15. Schriftenreihe des Nationalparks SchleswigHolsteinisches Wattenmeer, Boyens Buchverlag, Heide.

Ungar IA (1978) Halophyte seed germination. The Botanical Review 44:233-264. doi:10.1007/BF02919080.

Ungar IA (1998) Are biotic factors significant in influencing the distribution of halophytes in saline habitats? The Botanical Review 64:176-199. doi:10.1007/BF02856582.

van Diggelen J (1991) Effects of inundation stress on salt marsh halophytes. In: Rozema J, Verkleij JAC (eds), Ecological responses to environmental stresses. Springer Netherlands, Dordrecht, pp $62-75$.

Vanguelova EI, Nortcliff S, Moffat AJ, Kennedy F (2007) Short-term effects of manipulated increase in acid deposition on soil, soil solution chemistry and fine roots in Scots pine (Pinus sylvestris) stand on a podzol. Plant and Soil 294:41-54. doi:10.1007/s11104-007-9225-5.

Veeneklaas RM (2013) Adaptation and dispersal of native salt-marsh species Elytrigia atherica. PhDThesis. University of Groningen.

Veeneklaas RM, Dijkema KS, Hecker N, Bakker JP (2013) Spatio-temporal dynamics of the invasive plant species Elytrigia atherica on natural salt marshes. Applied Vegetation Science 16:205-216. doi:10.1111/j.1654-109X.2012.01228.x.

Visser E, Blom C, Voesenek L (1996) Flooding-induced adventitious rooting in Rumex: morphology and development in an ecological perspective. Acta botanica Neerlandica 45:17-28.

Wijte A, Gallagher JL (1996) Effect of oxygen availability and salinity on early life history stages of salt marsh plants. 1. Different germination strategies of Spartina alterniflora and Phragmites australis (Poaceaei). American Journal of Botany 83:1337-1342.

Zotz G, Mikona C (2003) Photosynthetic Induction and Leaf Carbon Gain in the Tropical Understorey Epiphyte, Aspasia principissa. Annals of Botany 91:353-359. doi:10.1093/aob/mcg021. 


\section{CHAPTER}

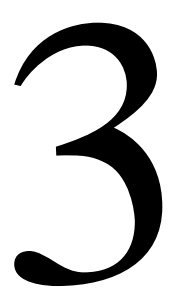

Effects of inundation, nutrient availability and plant species diversity on fine root mass and morphology across a saltmarsh flooding gradient

Regine Redelstein, Dietrich Hertel, Thomas Dinter, Christoph Leuschner

Published in

Frontiers in Plant Science 2018, Vol. 9, Article 98

doi:10.3389/fpls.2018.00098 


\begin{abstract}
Saltmarsh plants are exposed to multiple stresses including tidal inundation, salinity, wave action and sediment anoxia, which require specific root system adaptations to secure sufficient resource capture and firm anchorage in a temporary toxic environment. It is well known that many saltmarsh species develop large below-ground biomass (roots and rhizomes) but relations between fine roots, in particular, and the abiotic conditions in salt marshes are widely unknown. We studied fine root mass ( $<2 \mathrm{~mm}$ in diameter), fine root depth distribution and fine root morphology in three typical communities (Spartina anglica-dominated pioneer zone, Atriplex portulacoides-dominated lower marsh, Elytrigia atherica-dominated upper marsh) across elevational gradients in two tidal salt marshes of the German North Sea coast (a mostly sandy marsh on a barrier island (Spiekeroog), and a silty-clayey marsh on the mainland coast (Westerhever)). Fine root mass in the $0-40 \mathrm{~cm}$ profile ranged between 750 and $2500 \mathrm{~g} \mathrm{~m}^{-2}$ in all plots with maxima at both sites in the lower marsh with intermediate inundation frequency and highest plant species richness indicating an effect of biodiversity on fine root mass. Fine root mass and, even more, total fine root surface area (maximum $340 \mathrm{~m}^{2} \mathrm{~m}^{-2}$ ) were high compared to terrestrial grasslands, and were greater in the nutrient-poorer Spiekeroog marsh. Fine root density showed only a slight or no decrease towards $40 \mathrm{~cm}$ depth. We conclude that the standing fine root mass and morphology of these salt marshes is mainly under control of species identity and nutrient availability, but species richness is especially influential. The plants of the pioneer zone and lower marsh possess well adapted fine roots and large standing root masses despite the often water-saturated sediment.
\end{abstract}

Keywords: Diversity effect, Nutrient availability, Root depth distribution, Sediment texture, Specific root area, Tidal inundation gradient 


\subsection{Introduction}

The plants of temperate salt marshes are exposed to multiple stresses such as frequent flooding associated with salinity, temporary anoxia in the sediment, and possibly sulfide and manganese toxicity together with mechanical stress and sediment coverage (Leuschner and Ellenberg 2017). Despite these constraints, some saltmarsh plants such as cordgrass (Spartina spp.) and sea purslane (Atriplex portulacoides) are known to be highly productive (Bouchard and Lefeuvre 2000; Smith et al. 1979; Schubauer and Hopkinson 1984). Many saltmarsh species develop extensive root systems and it has been found that plant biomass and productivity may be larger below- than above-ground in these environments (Smith et al. 1979; Groenendijk and Vinklievaart 1987; Schubauer and Hopkinson 1984; Tripathee and Schaefer 2015; Valiela et al. 1976). For example, 50 to $90 \%$ of the productivity of Spartina alterniflora was found to be contributed by root and rhizome growth and turnover in a salt marsh in the eastern United States (Valiela et al. 1976; Darby and Turner 2008). This suggests that a large part of the soil organic carbon contained in saltmarsh sediments is derived from roots, and below-ground productivity is an important factor in the carbon and nutrient cycles of these semi-aquatic ecosystems. Due to their short lifespan and rapid turnover, fine and very fine roots (diameters $<2 \mathrm{~mm}$ ) act as an important sink for carbohydrates supplied by photosynthesis (Jackson et al. 1997; Gill and Jackson 2000). However, most studies on the saltmarsh below-ground compartment focus on the total (i.e. fine and coarse root, and rhizome) biomass, while only few studies have addressed the structure and dynamics of roots $<2 \mathrm{~mm}$ in diameter, i.e. the fraction of the root system which likely is responsible for water and nutrient uptake.

Coastal salt marshes are extreme habitats, which require specific adaptations of the plants that colonize them. Species growing in the frequently inundated lower zone of the marsh have to cope with anoxia and reducing conditions in the soil. This environment may trigger the formation of aerenchyma in roots and rhizomes, which facilitate oxygen supply, and foster the development of strategies to exclude and excrete salt (Rozema et al. 1981; Rozema et al. 1985). Root aerenchyma can increase the plant's capacity to detoxify potentially harmful ions such as $\mathrm{S}^{2-}, \mathrm{Fe}^{2+}$ or $\mathrm{Mn}^{2+}$ in the rhizosphere (Lee 1999; Lee 2003; Maricle and Lee 2002). In the upper marsh, stress from inundation is less frequent, but plant growth may additionally be limited by nitrogen shortage (Levine et al. 1998; Kiehl et al. 1997; Valiela and Teal 1974; van Wijnen and Bakker 1999). The large belowground biomass often found in salt marshes is thus not surprising, as it may be needed to secure nutrient and water acquisition, and to anchor the plants in a relatively unstable sediment. Root:shoot mass ratios exceeding unity are also found in other stressful environments such as nutrient-poor or dry grasslands and cold tundra ecosystems (Jackson et al. 1996; Leuschner et al. 2013). 
Small-scale heterogeneity is a characteristic feature of many temperate saltmarsh ecosystems. Even minor elevation differences in the salt marsh may cause great spatial differences in inundation frequency, water level height, salinity and the degree of soil anoxia, and thus in the conditions for root growth in the sediment. This is also reflected in the zonation of saltmarsh communities (Bakker 2014; Leuschner and Ellenberg 2017), with salinity and tidal inundation as the main factors driving species distribution across the elevation gradient (Armstrong et al. 1985; Cooper 1982; Rozema et al. 1985; Ungar 1998).

Root system studies across elevation and water level gradients and in different sediment types should reflect the small-scale vegetation mosaic in salt marshes and may display the associated plant strategies to cope with varying environmental constraints. An example illustrating species differences is the study of Bouma et al. (2003) in a Dutch salt marsh, who found root longevity to be shorter in the highly competitive upper marsh grass Elytrigia atherica than in the more stress-tolerant grass Spartina anglica from the lowermost pioneer zone. Results of Steudel et al. (2011) and Ford et al. (2016) suggest that plant species richness, which can vary between one species per plot at the most stressful sites and more than ten species at higher elevation, could also influence the root mass of saltmarsh communities, modifying the influence of abiotic factors. Also for other ecosystems it is known that plant diversity increases root biomass (Eisenhauer et al. 2017; Mommer et al. 2010; Mueller et al. 2013). Resource capture in more diverse communities may for example be enhanced by adjusting the depth distribution of roots between species (i.e. 'complementarity effect'; Loreau and Hector 2001; Cardinale et al. 2007; Mommer et al. 2010). Furthermore, the 'selection effect' may increase biomass production in more diverse communities, when a very productive species dominates the biomass of the species mixture (Loreau and Hector 2001).

In this study, we examined the variation in fine root mass, fine root depth distribution and fine root morphology across elevational gradients in two common types of North Sea tidal salt marshes, a barrier island marsh with mostly sandy sediment and a foreland salt marsh with silty-clayey sediment. Due to these differences in geomorphology, sites assumedly differ in nutrient availability and further soil properties, such as bulk density, enabling the investigation of these parameters on fine root traits. The variation in elevation and inundation frequency was addressed by transects reaching from the low-elevation pioneer zone with dominant Spartina stands with daily inundation to the high-elevation upper salt marsh with dominant Elytrigia swards that experience flooding only 4 to 8 times per month. We focused on fine roots $<2 \mathrm{~mm}$ in diameter due to their relevance for resource uptake, while larger roots and rhizomes with primarily storage, conduction and anchorage function were not considered. We searched for those abiotic and biotic factors (inundation frequency, salinity, soil texture, soil nutrient and element content, species diversity), which exert the largest influence on fine 
root mass and morphology in the studied salt marshes. We tested the hypotheses that (i) fine root mass is on average greater in the sandy than the silty sediments due to higher nutrient availability in the latter, (ii) the decrease of rooting depth with increasing soil depth is less pronounced in the pioneer zone due to an assumed greater adaptive potential of the inhabiting species to the anoxic sediment conditions, (iii) the likely more stress-tolerant species of the frequently inundated pioneer zone have more robust roots with lower specific root area and specific root length, but higher root tissue density than the more competitive species of the upper marsh, and (iv) plant species richness has a positive effect on the root mass of the community.

\subsection{Materials and Methods}

Study sites

Sampling was conducted in late September (i.e. towards the end of the growing season) at two saltmarsh sites of the German North Sea coast (Fig. 3.1A): one site was located on the south coast of Spiekeroog Island (Lower Saxony, 53 45'44"N, $7^{\circ} 43^{\prime} 23^{\prime \prime} \mathrm{E}$ ), the second site was located in a salt marsh in the Tümlau Bay close to Westerhever (Schleswig-Holstein, 54²2'22"N, 8³8'47"E). Sites differ in terms of geomorphology: Spiekeroog is a barrier island with marshes on the leeward side developed on a base layer of sand on which a thin layer of silt has been deposited (Bakker 2014). This marsh has developed naturally in the shelter of sand dunes and is not grazed by livestock. In contrast, the foreland salt marsh in Westerhever is located on the mainland coast on the seaward side of an artificial dike and has developed on a fine-grained sediment consisting of a thick $(0.5-0.8 \mathrm{~m})$ clayey silt layer (Peiter 2004). This salt marsh was drained in the early $20^{\text {th }}$ century and has been intensively grazed until 1991 (Stock et al. 2005).

In both salt marshes, six plots of $2 \mathrm{~m} \times 2 \mathrm{~m}$ size were installed in each of the three saltmarsh zones resulting in a total of 18 plots per site. Zones differed in elevation relative to sea level and thus inundation frequency and inhabiting saltmarsh communities (Fig. 3.1B). The pioneer zone is inundated by most tides except the lowest neap tides and the dominant species is Spartina anglica C.E. Hubb., accompanied by Salicornia stricta Dumort., Suaeda maritima (L.) Dumort., Aster tripolium L. and Puccinellia maritima (Huds.) Parl.. The subsequent lower salt marsh, inundated less frequently only by spring tides, is the most species-rich community with high cover of Atriplex portulacoides L. and Puccinellia maritima and occurrence of Cochlearia danica L., Suaeda maritima, Limonium vulgare Mill., Artemisia maritima L., Aster tripolium, Triglochin maritima L., Plantago maritima L. s. str., Salicornia europaea L. s. str., Spartina anglica and Spergularia media (L.) C. 
Presl at lower frequency. The upper salt marsh is inundated only during very high spring tides and storm events and is dominated by Elytrigia atherica (Link) Kerguélen with a few individuals of Atriplex prostrata Boucher ex DC.

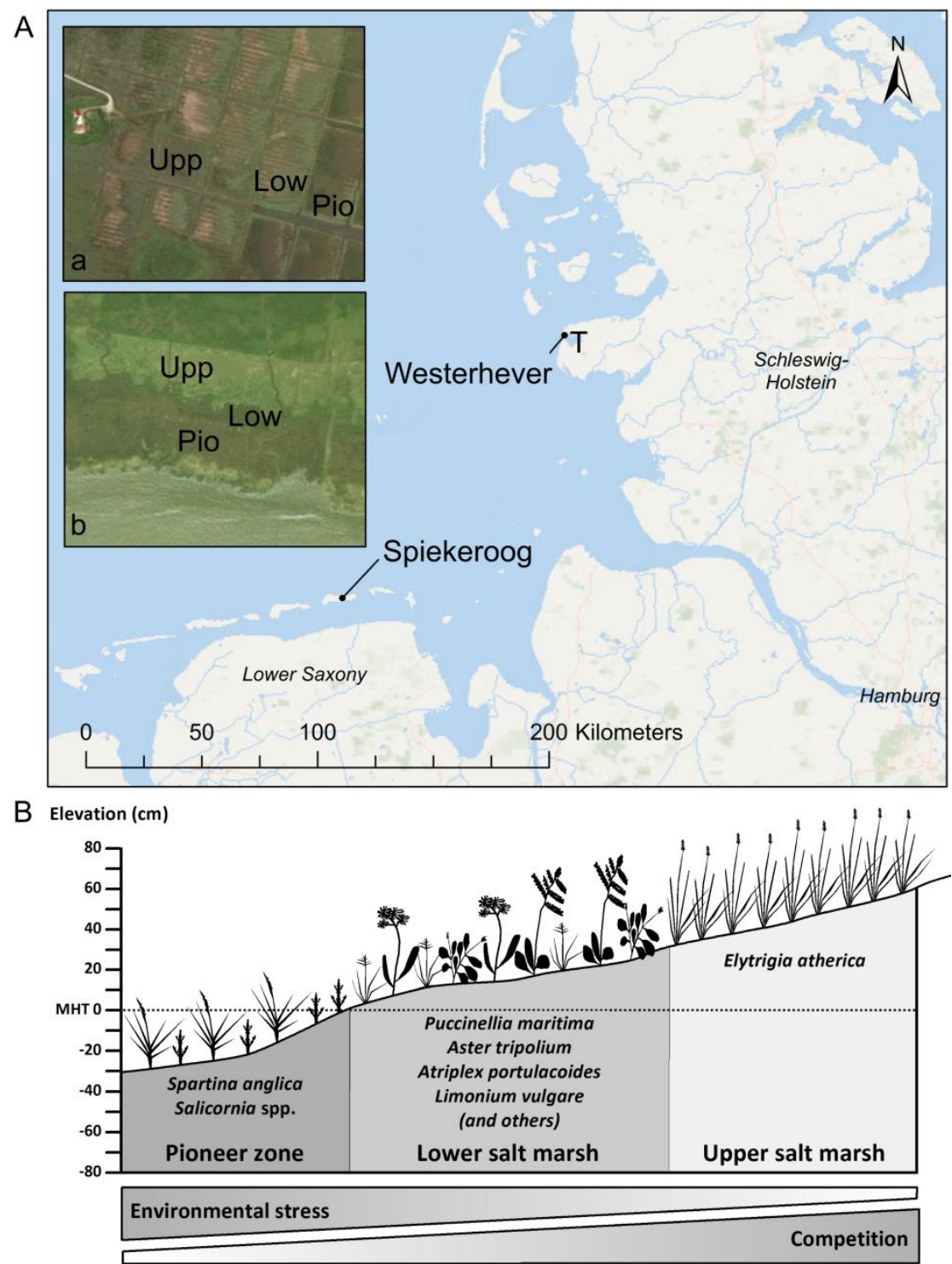

Figure 3.1: A) Map of the German North Sea coast with the location of the two study sites Spiekeroog Island and Westerhever and location of the sampling plots in the three saltmarsh zones pioneer zone (Pio), lower salt marsh (Low) and upper salt marsh (Upp). Detail maps: Tümlau Bight in Westerhever (a) and south side of Spiekeroog Island (b). "T" marks the location of the tide gauge station from which water level data for Westerhever were obtained (Service layer Credits: Esri, DeLorme, GEBCO, NOAA NGDB, and other contributors, Source: Esri, DigitalGlobe, GeoEye, Earthstar Geographics, CNES/Airbus DS, USDA, USGS, AeroGRID, IGN, and the GIS User Community). B) Zonation of a salt marsh with elevations relative to the mean high tide (MHT) water level and species typically inhabiting the three zones in a north-west European salt marsh. 


\section{Tidal inundation and soil properties}

To measure water level variation and the frequency of tidal inundations of the plots, a RBRduo |TD wave sensor (RBR Ltd., Ontario, Canada) was installed on the tidal flat of Spiekeroog and its elevation determined relative to the height of the saltmarsh plots using a differential GPS. For the Westerhever site, data on water level fluctuation were provided from the nearby gauge station Tümlau AP (Fig. 3.1a) by the Schleswig-Holstein Agency for Coastal Protection, National Park and Marine Conservation. The elevation of the Westerhever saltmarsh site is specified in Stock (2012). Inundation frequency and flooding duration of the three community types were calculated from the data on water level fluctuation and plot elevation.

From each plot, two soil samples for chemical analysis were taken, separated into the upper $A_{h} / A_{i-}$ horizon (mineral horizon of the topsoil with accumulation of humus (h) or initial humus development in the pioneer zone (i); approx. 0-20 cm depth) and the lower $\mathrm{G}_{\mathrm{o}} / \mathrm{G}_{\mathrm{r}}$-horizon (horizon affected by groundwater, oxidized (o) or reduced (r); approx. $>20 \mathrm{~cm}$ depth) and combined to one pooled sample per soil horizon. For the analysis of grain size, an aliquot $(5 \mathrm{~g})$ of dried soil $\left(105^{\circ} \mathrm{C}\right)$ was used. To account for organic substances, carbonates and iron-oxides, samples were treated with $\mathrm{H}_{2} \mathrm{O}_{2}, \mathrm{HCl}$ and Na-Dithionite prior to analysis. Particles $>20 \mu \mathrm{m}$ were separated using sieves of different mesh sizes, whereas particles $<20 \mu \mathrm{m}$ were separated by performing Atterberg cylinder analysis of sinking velocity. The remaining soil was dried at $40{ }^{\circ} \mathrm{C}$ until constant weight and used for chemical analyses. Samples were sieved to $2 \mathrm{~mm}$ and ground in a ball mill (200 rpm for $5 \mathrm{~min}$ ). One aliquot of a sample was digested with $65 \% \mathrm{HNO}_{3}$ (Heinrichs et al. 1986) and total element contents ( $\mathrm{Al}, \mathrm{Ca}, \mathrm{Fe}, \mathrm{K}, \mathrm{Mg}$, $\mathrm{Mn}, \mathrm{Na}, \mathrm{P}, \mathrm{S}$ ) were determined using Inductively Coupled Plasma - Optical Emission Spectroscopy (ICP-OES, iCAP 6300 Duo View ICP Spectrometer, Thermo Fisher Scientific GmbH, Dreieich, Germany). From another aliquot, inorganic carbon was removed by treatment with $1 \mathrm{M} \mathrm{HCl}$; this sample was dried at $50^{\circ} \mathrm{C}$ and analyzed for organic carbon $\left(\mathrm{C}_{\text {org }}\right)$ and total nitrogen $\left(\mathrm{N}_{\mathrm{t}}\right)$ using a $\mathrm{C} / \mathrm{N}$ elemental analyzer (Flash 2000, Thermo Fisher Scientific, Cambridge, UK). A third aliquot was used for determination of plant-available phosphorous according to Schüller (1969): $5 \mathrm{~g}$ of soil were added to $100 \mathrm{ml}$ of calcium-acetate-lactate (CAL)-solution and shaken automatically for $90 \mathrm{~min}$. Extracts were filtered into Falcon ${ }^{\circledR}$ Tubes, whereby the first $5 \mathrm{ml}$ were discarded, and stored at $4^{\circ} \mathrm{C}$ until further analysis no longer than $24 \mathrm{~h}$. Plant-available phosphorous was measured photometrically as a molybdate-complex using a microplate reader at $820 \mathrm{~nm}$ wavelength. For the analysis of mineral nitrogen $\left(\mathrm{NO}_{3}{ }^{-}\right.$and $\left.\mathrm{NH}_{4}{ }^{+}\right)$, a further aliquot of fresh soil was immediately frozen after sampling. $20 \mathrm{ml}$ of a $2.5 \mathrm{M} \mathrm{K}_{2} \mathrm{SO}_{4}$ solution were added to $5 \mathrm{~g}$ of fresh soil and thoroughly mixed for $30 \mathrm{~s}$. Samples were shaken for $2 \mathrm{~h}$ on an overhead shaker and finally filtered through a Whatman (no. 2) 
filter. Concentrations of ammonium and nitrate in the extracts were determined using a continuous flow injection colorimeter (Cenco/Skalar Instruments, Breda, The Netherlands).

\section{Sampling and processing of fine roots and aboveground biomass}

For the inventory of fine root mass, samples were taken with a stainless steel corer $(35 \mathrm{~mm}$ diameter, $400 \mathrm{~mm}$ length) on all plots to a depth of $40 \mathrm{~cm}$. Soil cores were divided into depth intervals of 0$5 \mathrm{~cm}, 5-10 \mathrm{~cm}, 10-20 \mathrm{~cm}$ and $20-40 \mathrm{~cm}$ and the samples were stored frozen until processing in the laboratory. The sediment material was washed over a sieve with $200 \mu \mathrm{m}$ mesh size to separate roots from finest-grained sediment. Under a stereomicroscope the roots were further cleaned and separated from rhizomes and other organic material. Only fine roots $<2 \mathrm{~mm}$ in diameter were considered for analysis. After the extraction of larger fine root fragments (>1 cm length), the remaining sediment with small rootlets was evenly distributed on a sheet of filter paper subdivided into 36 squares according to Hertel and Leuschner (2002). Six of the squares were randomly selected and all fine root fragments in the squares collected quantitatively under a binocular. The dry mass of these subsamples was extrapolated to the 36 squares to estimate the total mass of finest rootlets in the sample. In selected subsamples, we separated dead from living fine root material under the microscope to estimate the fraction of living fine roots. A non-turgid stele and periderm, the loss of the stele, or differing root color and elasticity were used as indicators of root death. Since the proportion of dead fine roots was $<10 \%$ in all samples, we decided to refrain from distinguishing between dead and live roots in every sample in order to process a larger number of replicate samples. Thus, all data refer to total fine root mass which consists to $>90 \%$ of biomass.

Root morphological traits were determined by scanning the extracted roots on a flatbed scanner. Total root length, root surface area, root volume and root diameter were measured using the software WinRhizo (Régent Instruments, Quebec, Canada). After scanning, roots were oven dried at $70{ }^{\circ} \mathrm{C}$ for $72 \mathrm{~h}$ and weighed to determine dry mass. Specific root length (SRL, root length/dry weight), specific root area (SRA, root surface area/dry weight) and root tissue density (RTD, dry weight/root volume) were calculated from these measurements. Cumulative root surface area (Root Area Index, RAI) was calculated from SRA and fine root mass for a specific plot. For analyzing the $\mathrm{C}$ and $\mathrm{N}$ content of root mass, the dried roots were ground in a vibrating disc mill and a subsample of $5 \mathrm{mg}$ was analyzed in a $\mathrm{C} / \mathrm{N}$ elemental analyzer by gas chromatography (vario EL III; elementar, Hanau, Germany).

The percentage cover of all species in the $2 \mathrm{~m} \times 2 \mathrm{~m}$ plots was estimated with the Londo scale to the next $10 \%$ (> $10 \%$ cover) or $1 \%(<10 \%$ cover $)$. Plant species diversity in the $4 \mathrm{~m}^{2}$ plots was expressed by Shannon's H. Aboveground biomass was sampled in all plots by randomly placing a 
square of $10 \mathrm{~cm} \times 10 \mathrm{~cm}$ in the plot and cutting all plant stems directly at the soil surface inside the square. Biomass was separated from necromass, cleaned in the laboratory, dried at $70{ }^{\circ} \mathrm{C}$ for $72 \mathrm{~h}$ and weighed.

\section{Statistical analysis}

Statistical analyses were conducted using R 3.3.2 software (R Development Core Team 2016). Oneway Analysis of Variance (ANOVA) with Tukey's HSD test was applied for multiple comparisons between saltmarsh communities and sites (ANOVA and HSD-test, packages 'car' and 'agricolae', respectively). Where normality of residuals and homoscedasticity were not given, values were logtransformed to meet these requirements. When assumption of normality could not be achieved, we used the Kruskal-Wallis test (kruskalmc, package 'pgirmess') for multiple comparisons between communities and sites. Welch's two sample t-test was used for comparisons between soil horizons. Step-wise multiple linear regressions with forward and backward variable selection were carried out with the 'MASS' package to identify the best predictor variables for fine root mass. The initial model included total phosphorous content, mineral nitrogen content, Shannon's H, aboveground biomass, and the soil $\mathrm{Na}$ and $\mathrm{S}$ content; the final model was selected by means of minimum AIC. A significance level of $p<0.05$ was used throughout. A principal components analysis (PCA) was conducted with the software CANOCO, version 5.02 (Biometris, the Netherlands) to analyze interrelationships between fine root mass and morphology, and soil properties across the different saltmarsh communities and sites.

\subsection{Results}

Tidal inundation regime, soil properties and plant species diversity

Due to the local tidal flat morphology, the pioneer zone plots in Spiekeroog were more frequently inundated than those in Westerhever (46 vs. 20 flooding events per month), whereas flooding events in the upper salt marsh occurred less frequently than in Westerhever (4 vs. 8 events per month; Table 3.1). The inundation frequency gradient from the pioneer zone to the upper salt marsh was thus steeper in the Spiekeroog transect. The two study sites also differed with respect to sediment texture and chemistry (Table 3.1, Table S3.1). 


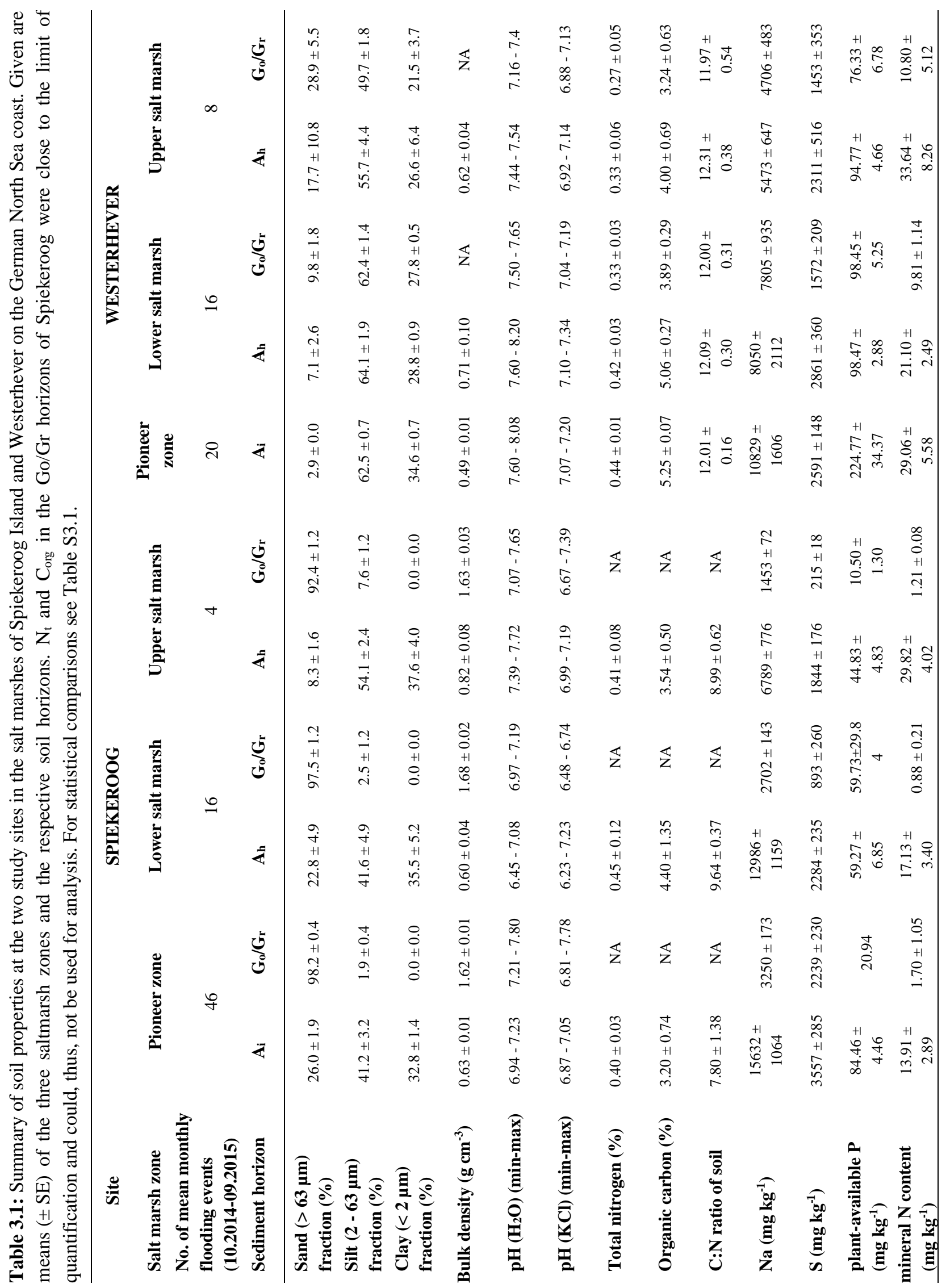


The Spiekeroog site was characterized by a larger sand but smaller silt fraction in both the uppermost $\left(A_{h}\right)$ and lower sediment layers $\left(G_{o} / G_{r}\right.$ horizon) compared to the generally finer textured Westerhever site $(p<0.05)$. An exception was the very silt- and clay-rich $\mathrm{A}_{\mathrm{h}}$ horizon in the upper salt marsh of Spiekeroog. While the Westerhever sediment profiles were relatively uniform in terms of grain size distribution, the Spiekeroog profiles were clearly stratified with a distinct increase in the sand fraction from the $A_{h}$ to the lower $G_{o} / G_{r}$ horizon $(p<0.05)$. This was reflected in a significant $(p<0.05)$ decrease in the mineral $\mathrm{N}$ and plant-available $\mathrm{P}$ content of the soil as well as in the $\mathrm{Na}$ and $\mathrm{S}$ contents towards the subsoil in Spiekeroog; this decrease was not as pronounced in Westerhever. At both sites, the grain size composition did not differ significantly between the pioneer, lower and upper saltmarsh zone. While the total $\mathrm{N}$ content of the sediment was similar across sites, the soil organic carbon content of the sediment and the related $\mathrm{C}: \mathrm{N}$ ratio tended to be higher in Westerhever (significant in the topsoil of the pioneer zone and lower salt marsh, $p<0.05$ ). While plant-available $\mathrm{P}$ was detected with significantly higher concentrations in the Westerhever sediments $(p<0.05)$, especially in the topsoil, the $\mathrm{K}_{2} \mathrm{SO}_{4}$-exchangeable nitrate and ammonium concentrations in Westerhever were higher in the deeper soil than in Spiekeroog $(p<0.05)$. The total $\mathrm{Na}$ and $\mathrm{S}$ contents were particularly high in the frequently inundated pioneer zone of Spiekeroog and decreased towards the upper salt marsh in both soil horizons $(p<0.05)$.

At both sites, the lower saltmarsh zones showed greatest plant species richness (10 species per plot at both sites) and Shannon diversity (H': 0.56 at Spiekeroog and 0.33 at Westerhever), whereas species richness and diversity in the upper salt marsh were lowest ( 2 species per plot; H': 0.02 at Spiekeroog and 0.03 at Westerhever). Mean species number in the pioneer zone plots was 4 (Spiekeroog) and 7 (Westerhever) and Shannon's H was 0.2 (Spiekeroog) and 0.27 (Westerhever) (Tables S3.1 and S3.2).

Fine root and aboveground biomass and their dependence on environmental factors and plant diversity

Total fine root mass $(0-40 \mathrm{~cm})$ was at both sites greatest in the lower salt marsh $\left(2547 \mathrm{~g} \mathrm{~m}^{-2}\right.$ in Spiekeroog and $2379 \mathrm{~g} \mathrm{~m}^{-2}$ in Westerhever) and smallest in the upper salt marsh $\left(1579 \mathrm{~g} \mathrm{~m}^{-2}\right.$ in Spiekeroog and $759 \mathrm{~g} \mathrm{~m}^{-2}$ in Westerhever) (Fig. 3.2). However, this difference was only significant in Westerhever $(p<0.05)$. Aboveground biomass decreased in Spiekeroog from the pioneer zone $\left(1048 \mathrm{~g} \mathrm{~m}^{-2}\right)$ to the upper saltmarsh $\left(481 \mathrm{~g} \mathrm{~m}^{-2}\right)$ community (difference not significant), while it peaked in Westerhever in the lower salt marsh $\left(2376 \mathrm{~g} \mathrm{~m}^{-2}\right)$, which was significantly greater than in the pioneer zone $\left(1134 \mathrm{~g} \mathrm{~m}^{-2}, p<0.05\right)$. Differences between the two sites in aboveground biomass in 
a given zone were larger than for fine root mass. In the Westerhever salt marsh, aboveground biomass was generally larger than in Spiekeroog on the sandy sediment (significant for the lower and upper salt marsh, $p<0.05$ ) (Fig. 3.2).

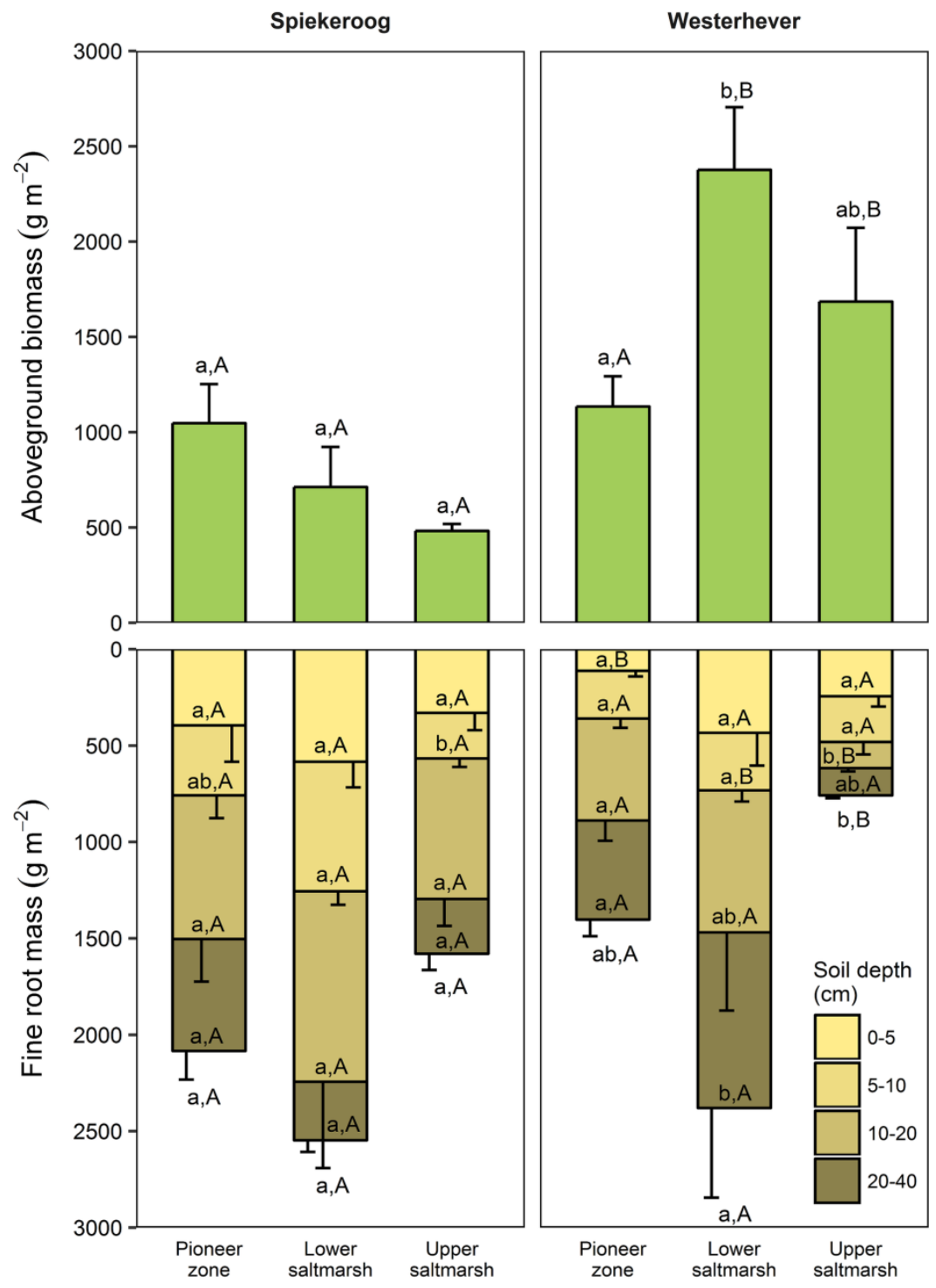

Figure 3.2: Aboveground biomass and fine root mass in the three saltmarsh communities at the two study sites $(\mathrm{n}=6$, means $\pm \mathrm{SE}$ ). Different letters indicate significant differences between communities at a site $(\mathrm{a}, \mathrm{b})$ or between the sites within a community type (A,B) (Kruskal-Wallis multiple comparison test, $p<0.05$ ). Letters inside the bars indicate significant differences for different sediment horizons, letters below bars stand for the entire soil profile.

The ratio of fine root mass:aboveground biomass was in all communities at both sites greater than unity (except for the upper salt marsh in Westerhever), and reached a maximum of 4.8 in the lower salt marsh of Spiekeroog (Table 3.2). The ratio was generally greater in Spiekeroog than in 
Westerhever; this difference between sites was significant in the lower and upper salt marsh $(p<0.05)$ but diminished in the pioneer zone. Root area index (RAI, i.e. total fine root surface area) in the sediment to $40 \mathrm{~cm}$ was at both sites greatest in the lower salt marsh (335 and $205 \mathrm{~m}^{2} \mathrm{~m}^{-2}$ in Spiekeroog and Westerhever, respectively, Fig. 3.3). In the pioneer zone and upper saltmarsh communities, RAI was significantly greater in Spiekeroog than in Westerhever (125 vs. 62 and 206 vs. $48 \mathrm{~m}^{2} \mathrm{~m}^{-2}$ in the pioneer zone and upper salt marsh, respectively; $p<0.05$ ).

Table 3.2: Fine root mass:aboveground biomass ratio (median values) in the three saltmarsh zones at both study sites. Different letters indicate significant differences between zones within a site (a) or between sites within a zone (A,B) analyzed by Kruskal-Wallis multiple comparisons $(p<0.05)$.

\begin{tabular}{llll}
\hline Root:shoot biomass ratio & Pioneer zone & Lower salt marsh & Upper salt marsh \\
\hline Spiekeroog & $1.85^{\mathrm{a}, \mathrm{A}}$ & $4.76^{\mathrm{a}, \mathrm{A}}$ & $3.52^{\mathrm{a}, \mathrm{A}}$ \\
Westerhever & $1.15^{\mathrm{a}, \mathrm{A}}$ & $1.20^{\mathrm{a}, \mathrm{B}}$ & $0.57^{\mathrm{a}, \mathrm{B}}$ \\
\hline
\end{tabular}
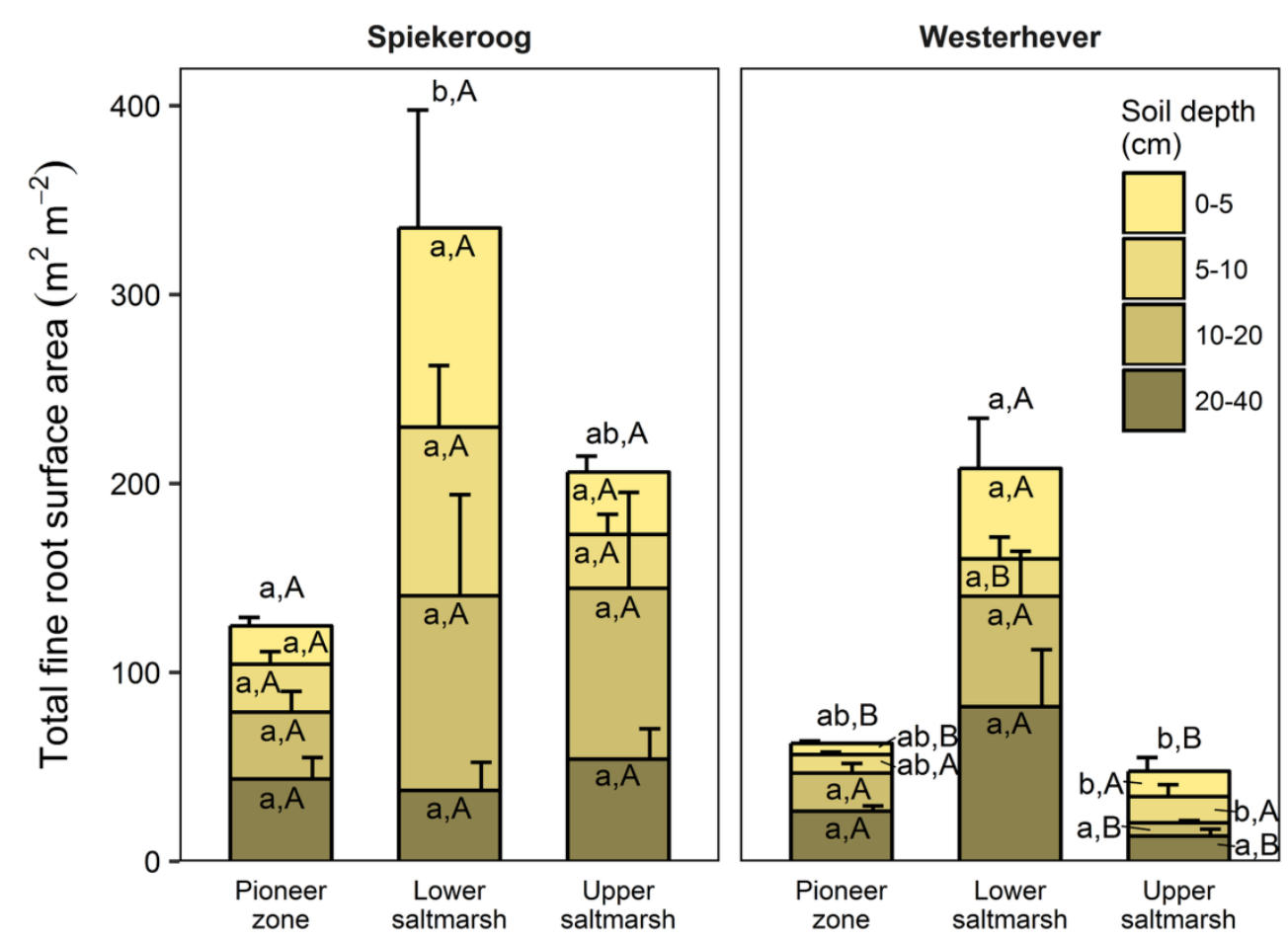

Figure 3.3: Cumulative fine root surface area per $\mathrm{m}^{2}$ ground area in the profile to $40 \mathrm{~cm}$ depth in the three saltmarsh communities at the study sites Spiekeroog and Westerhever ( $n=6$, means \pm SE). Different letters indicate significant differences between the communities at a site $(a, b)$ or between the two sites for a community type (A,B) according to Kruskal-Wallis multiple comparison tests $(p<0.05)$. Letters inside of the bars indicate significant differences for a given sediment horizon, letters above bars stand for the entire soil profile. 


\section{Vertical fine root distribution}

The density of fine roots (root mass per soil volume) decreased with increasing depth in the sediment at both sites and in all communities (Fig. 3.4). The decrease from the topsoil $(0-5 \mathrm{~cm})$ to the subsoil (20-40 cm) was, however, significant only in some cases (Westerhever: upper and lower salt marsh, Spiekeroog: upper salt marsh; Kruskal-Wallis multiple comparison test, $p<0.05$, data not shown). At $10 \mathrm{~cm}$ soil depth, there was a remarkable difference in fine root density in the lower salt marsh with very high values in Spiekeroog $\left(13.5 \mathrm{~g} \mathrm{dm}^{-3}\right)$ compared to Westerhever $\left(6 \mathrm{~g} \mathrm{dm}^{-3}\right)$. At both sites, the pioneer zone held the lowest percentage of roots in the upper $20 \mathrm{~cm}$ of soil, i.e. the highest percentage of deep-reaching roots (significant for Westerhever, $p<0.05$, Table 3.3).

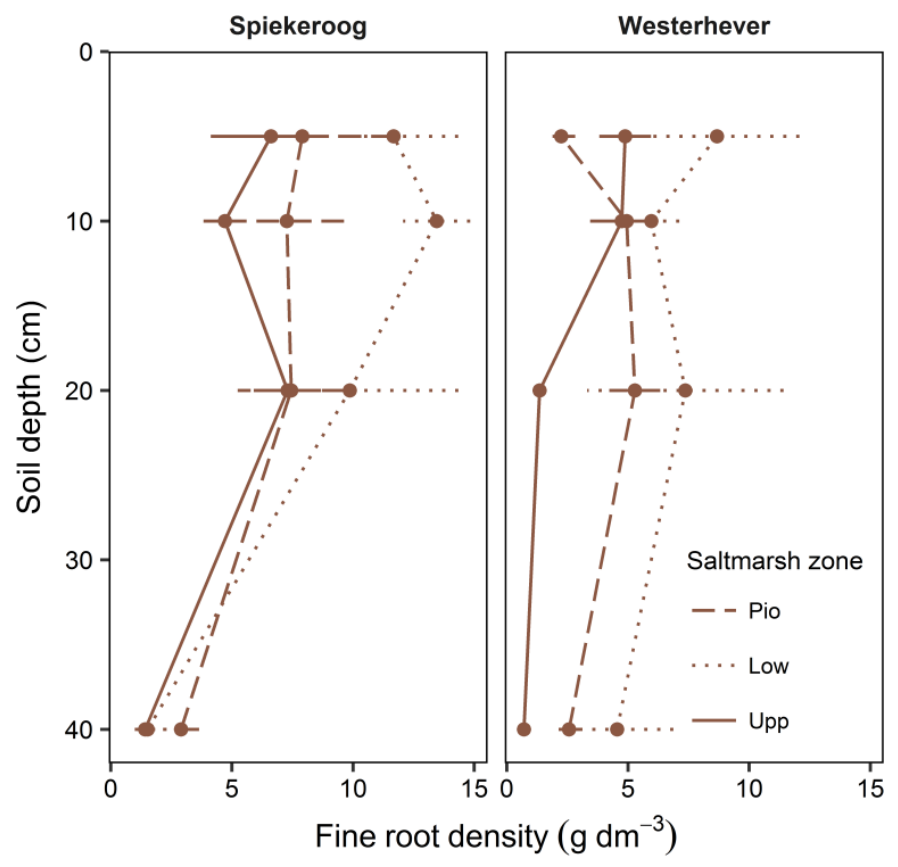

Figure 3.4: Change in fine root density (fine root mass per soil volume) with soil depth in the three saltmarsh communities $($ Pio $=$ pioneer zone, Low $=$ lower salt marsh and Upp $=$ upper salt marsh $)$ at the study sites Spiekeroog and Westerhever $(n=6$, means $\pm S E)$.

Table 3.3: Percentage of fine root mass in the upper $20 \mathrm{~cm}$ of soil of the total soil profile $(0-40 \mathrm{~cm})$ (means \pm $\mathrm{SE}, \mathrm{n}=6)$. Different letters indicate significant differences between zones within a site $(\mathrm{a}, \mathrm{b})$ or between sites within a zone (A,B) analyzed by Kruskal-Wallis multiple comparisons $(p<0.05)$.

\begin{tabular}{lllc}
\hline $\begin{array}{l}\text { Percentage root mass in } \\
\text { upper } 20 \text { cm of soil }\end{array}$ & Pioneer zone & Lower salt marsh & Upper salt marsh \\
\hline Spiekeroog & $69.48 \pm 4.88^{\mathrm{a}, \mathrm{A}}$ & $86.16 \pm 2.75^{\mathrm{a}, \mathrm{A}}$ & $82.88 \pm 3.54^{\mathrm{a}, \mathrm{A}}$ \\
Westerhever & $64.08 \pm 3.88^{\mathrm{a}, \mathrm{A}}$ & $66.05 \pm 7.65^{\mathrm{ab}, \mathrm{B}}$ & $81.26 \pm 1.71^{\mathrm{b}, \mathrm{A}}$ \\
\hline
\end{tabular}




\section{Relation between fine root mass and environmental factors and plant diversity}

Stepwise multiple regression analysis with the variables total $\mathrm{Na}, \mathrm{P}, \mathrm{S}$ and mineral $\mathrm{N}$ content in the sediment, Shannon diversity and aboveground biomass in the initial model revealed that Shannon diversity had a highly significant effect $(p<0.001)$ on fine root mass (Table 3.4$)$. This effect had a higher explanatory power than that of mineral $\mathrm{N}$ content in the sediment $(p<0.01)$ and also of the $\mathrm{Na}$ content as a proxy of the inundation regime $(p<0.05)$. The prominent role of the influence of plant diversity disappeared when the root mass in the lower $\mathrm{Go} / \mathrm{Gr}$ horizon was considered. Here, soil chemical parameters ( $\mathrm{Na}$ and total $\mathrm{P}$ content) were the only influential factors $(p<0.01)$.

Table 3.4: Predictor variables for fine root mass identified by stepwise multiple regression analyses (forward and backward variable selection) grouped by study site and soil depth.

\begin{tabular}{|c|c|c|c|c|}
\hline Model variables & Estimate & se & t value & $p$-value \\
\hline \multicolumn{5}{|c|}{ Best model fit: both study sites, all soil depths (AIC $\left.=-92.75, F=11.46, d f=3,58, p<0.001, R^{2}=0.37\right)$} \\
\hline (Intercept) & 7.23 & $1.2410^{-1}$ & 58.44 & $* * *$ \\
\hline $\mathrm{Na}$ & $2.4910^{-5}$ & $1.2310^{-5}$ & 2.02 & $*$ \\
\hline mineral $\mathrm{N}$ & $1.3110^{-2}$ & $4.1210^{-3}$ & -3.18 & $* *$ \\
\hline Shannon-Wiener index, $\mathrm{H}$ & 1.01 & $2.8210^{-1}$ & 3.57 & $* * *$ \\
\hline \multicolumn{5}{|c|}{ Best model fit: Spiekeroog, all soil depths $\left(A I C=-79.18, F=9.68, d f=2,33, p<0.001, R^{2}=0.37\right)$} \\
\hline (Intercept) & 7.23 & 0.11 & 68.51 & $* * *$ \\
\hline Shannon-Wiener index, $\mathrm{H}$ & 0.80 & 0.20 & 4.03 & $* * *$ \\
\hline aboveground biomass & 0.00 & 0.00 & 1.62 & n.s. \\
\hline \multicolumn{5}{|c|}{ Best model fit: Westerhever, all soil depths $\left(A I C=-27.12, F=6.10, d f=4,21, p<0.01, R^{2}=0.54\right)$} \\
\hline (Intercept) & 6.15 & $3.4310^{-1}$ & 17.92 & $* * *$ \\
\hline $\mathrm{Na}$ & $8.8110^{-5}$ & $3.6810^{-5}$ & 2.39 & $*$ \\
\hline Shannon-Wiener index, $\mathrm{H}$ & 1.80 & $7.5310^{-1}$ & 2.39 & $*$ \\
\hline aboveground biomass & $2.9310^{-4}$ & $1.3910^{-4}$ & 2.11 & $*$ \\
\hline total S & $-2.210^{-4}$ & $1.4310^{-4}$ & -1.54 & n.s. \\
\hline \multicolumn{5}{|c|}{ Best model fit: both study sites, $A_{h}$ horizon (AIC $\left.=-48.39, F=6.90, d f=3,30, p<0.01, R^{2}=0.41\right)$} \\
\hline (Intercept) & 7.36 & $2.4010^{-1}$ & 30.60 & $* * *$ \\
\hline mineral $\mathrm{N}$ & $-1.3810^{-2}$ & $5.8810^{-3}$ & -2.35 & $*$ \\
\hline Shannon-Wiener index, $\mathrm{H}$ & 1.05 & $3.8010^{-1}$ & 2.76 & $* *$ \\
\hline aboveground biomass & $-1.6910^{-4}$ & $9.0010^{-5}$ & -1.79 & n.s. \\
\hline \multicolumn{5}{|c|}{ Best model fit: both study sites, $G_{d} / G_{r}$ horizon $\left(A I C=-13.29, F=4.05, d f=3,24, p<0.05, R^{2}=0.34\right)$} \\
\hline (Intercept) & 5.05 & 0.28 & 18.343 & $* * *$ \\
\hline $\mathrm{Na}$ & $0.2910^{-3}$ & $0.1010^{-3}$ & 2.80 & $* *$ \\
\hline total P & $-1.8510^{-3}$ & $0.6010^{-3}$ & -3.06 & $* *$ \\
\hline aboveground biomass & $0.3210^{-3}$ & $0.2410^{-3}$ & 1.34 & n.s. \\
\hline
\end{tabular}

n.s.: $p>0.05, * p:<0.05, * *: p<0.01, * * *: p<0.001$ 


\section{Root morphological and chemical traits}

Specific root length (SRL) and specific root area (SRA) ranged between 46 and $120 \mathrm{~m} \mathrm{~g}^{-1}$ and between 455 and $1546 \mathrm{~cm}^{2} \mathrm{~g}^{-1}$, respectively, in all studied plots (Fig. 3.5). Significant differences between zones $(p<0.05)$ were only found in Westerhever, where the highest SRL was found in the lower salt marsh. Root tissue density (RTD) ranged from 0.17 to $0.34 \mathrm{~g} \mathrm{~cm}^{-3}$ with particularly high values in the pioneer zone and upper salt marsh of Westerhever. Significant site differences existed for SRL, SRA (lower values in Westerhever) and RTD (higher values in Westerhever) in the pioneer zone and the upper saltmarsh community $(p<0.05)$. Root diameter was relatively uniform across the plots (0.3-0.4 mm) with no site- and community-specific differences. Root nitrogen concentrations differed between all three communities at both sites $(p<0.05)$. They were highest in the lower salt marsh of both sites (16.7 and $14.1 \mathrm{mg} \mathrm{g}^{-1}$ in Spiekeroog and Westerhever, respectively) and lowest in the upper salt marsh of Spiekeroog $\left(12.4 \mathrm{mg} \mathrm{g}^{-1}\right)$ and the pioneer zone of Westerhever $\left(10.9 \mathrm{mg} \mathrm{g}^{-1}\right)$. Particularly high values were found in the pioneer zone and lower salt marsh of Spiekeroog (significant difference to Westerhever, $p<0.05$ ). 


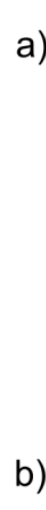

b)
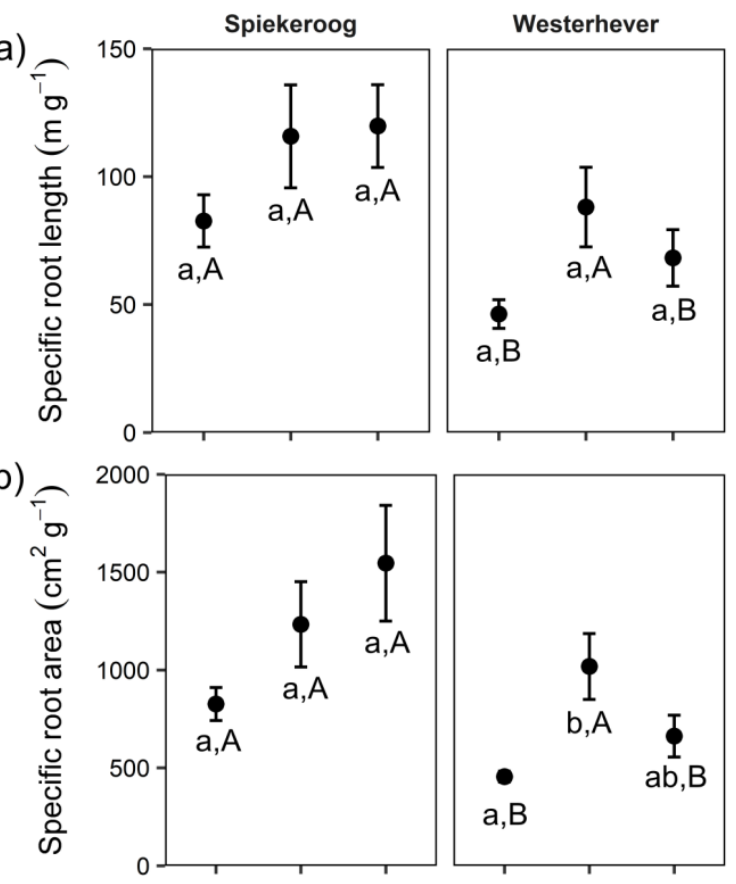

c)

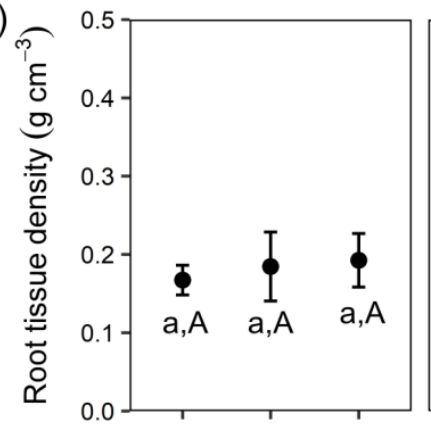

d)

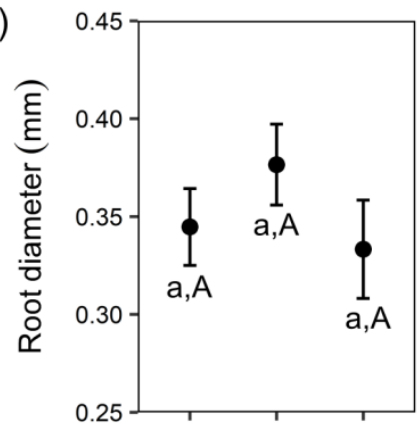

e)

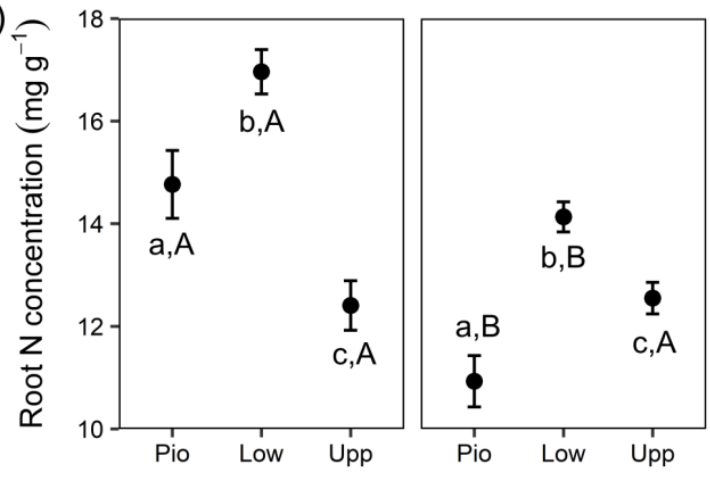

Figure 3.5: Means \pm SE of five fine root morphological traits in the three saltmarsh communities $(\mathrm{Pio}=$ pioneer zone, Low $=$ lower salt marsh and Upp = upper salt marsh) at the study sites Spiekeroog and Westerhever $(n=24)$. Different letters indicate significant differences between study sites and saltmarsh communities according to one-way ANOVA with Tukey's post-hoc test $(p<0.05)$. 


\section{Principal Components Analysis}

Ordination of the 36 plots with PCA based on the studied soil and root-related parameters confirmed the differentiation among the two study sites and three saltmarsh zones (Fig. 3.6, Table 3.5).

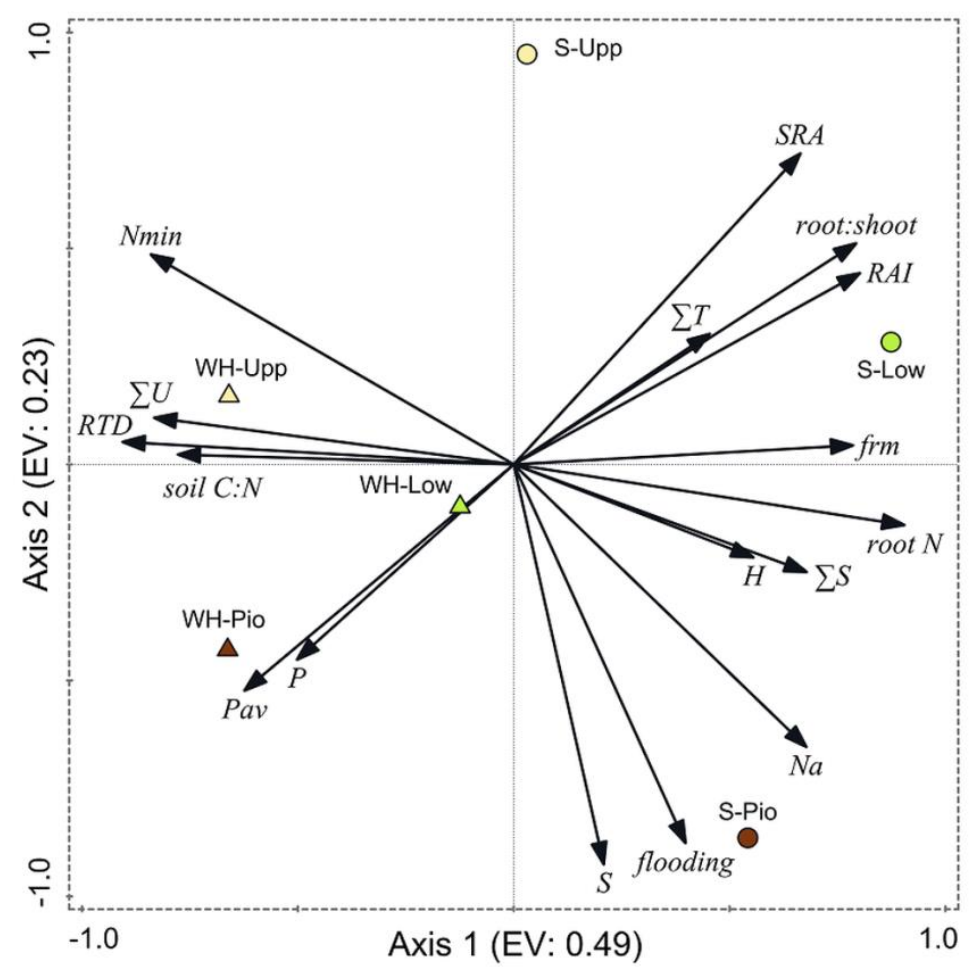

Figure 3.6: Plot showing the distribution of the three saltmarsh communities (Pio = pioneer zone, Low $=$ lower salt marsh and Upp = upper salt marsh) of the two sites Spiekeroog (S) and Westerhever (WH) in relation to the PCA axes 1 and 2 (EV: eigenvalues of the axes) and their association with important soil and root properties (SRA: specific root area, $\sum \mathrm{T}$ : clay fraction, RAI: root area index, FRM: fine root mass, root $\mathrm{N}$ : root $\mathrm{N}$ concentration, $\Sigma \mathrm{S}$ : sand fraction, $\mathrm{H}$ : Shannon-Wiener index, $\mathrm{Na}$ : $\mathrm{Na}_{\mathrm{t}}$ concentration in the sediment, flooding: no. of monthly flooding events, P: total P in the sediment, Pav: plant-available P in the sediment, RTD: root tissue density, $\sum \mathrm{U}$ : silt fraction, Nmin: mineral $\mathrm{N}$ concentration $\left(\mathrm{NO}_{3}{ }^{-}\right.$and $\left.\mathrm{NH}_{4}{ }^{+}\right)$in soil) in the upper soil horizon $\left(\mathrm{A}_{\mathrm{h}}\right)$. Vector length and angle are proportional to the direction and degree of their correlation with the plot ordination scores.

For the topsoil data $(0-20 \mathrm{~cm})$, the first axis (eigenvalue 0.48$)$ separated the two study sites, and associated fine root mass, SRA, root:shoot ratio, RAI and root N concentration with the Spiekeroog site, whereas mineral $\mathrm{N}$ content, RTD and soil silt fraction were more closely associated with the Westerhever site. The second axis (eigenvalue 0.23) separated the three saltmarsh communities along a gradient of decreasing distance to the ocean. Mineral $\mathrm{N}$ as well as SRA were associated with this 
axis in the direction of the upper salt marsh, whereas on the opposite side, flooding frequency, $\mathrm{S}, \mathrm{Na}$ and plant-available $\mathrm{P}$ contents of the soil were associated with this axis in the direction of the pioneer zone. The differences between the two study sites in terms of soil nutrient content in association with sediment texture were even clearer in the deeper sediment horizon $(20-40 \mathrm{~cm})$ than in the topsoil (Fig. S3.4).

Table 3.5: Results of a Principal Components Analysis (PCA) on the differentiation of the three saltmarsh zones at both study sites with respect to fine root mass, root morphological traits, species diversity and soil properties of the $A_{h}$-horizon. Given are the loadings of the selected variables along the first and second explanatory axes. Numbers in brackets below the axes indicate the eigenvalues (EV) of the axes. Numbers in bold mark the variables with closest correlation to the respective axis (cumulative fit values are given in brackets).

\begin{tabular}{lcc}
\hline & $\begin{array}{c}\text { Axis 1 } \\
\text { (EV 0.4855) }\end{array}$ & $\begin{array}{c}\text { Axis 2 } \\
\text { (EV 0.2342) }\end{array}$ \\
\hline fine root mass & $\mathbf{0 . 7 9}(0.62)$ & $0.04(0.62)$ \\
fine root:shoot ratio & $\mathbf{0 . 7 9}(0.63)$ & $\mathbf{0 . 5 1}(0.89)$ \\
specific root area & $0.66(0.44)$ & $\mathbf{0 . 7 2}(0.96)$ \\
root tissue density & $\mathbf{- 0 . 9 1}(0.82)$ & $0.05(0.82)$ \\
root N concentration & $\mathbf{0 . 9 0}(0.82)$ & $-0.14(0.84)$ \\
root surface area & $\mathbf{0 . 8 0}(0.64)$ & $0.44(0.84)$ \\
total Na in soil & $0.68(0.46)$ & $\mathbf{- 0 . 6 5}(0.89)$ \\
total P in soil & $-0.50(0.25)$ & $-0.45(0.46)$ \\
total S in soil & $0.21(0.04)$ & $\mathbf{- 0 . 9 3}(0.90)$ \\
C:N ratio in soil & $\mathbf{- 0 . 7 8}(0.60)$ & $-0.02(0.61)$ \\
plant-available P & $-0.62(0.39)$ & $\mathbf{- 0 . 5 2}(0.66)$ \\
mineral N & $\mathbf{- 0 . 8 4}(0.71)$ & $0.49(0.94)$ \\
$\sum$ Sand & $0.68(0.46)$ & $-0.25(0.52)$ \\
$\sum$ Silt & $\mathbf{- 0 . 8 3}(0.69)$ & $0.11(0.71)$ \\
$\sum$ Clay & $0.45(0.21)$ & $0.30(0.30)$ \\
H (Shannon-Wiener index) & $0.56(0.31)$ & $-0.22(0.36)$ \\
Flooding events & $0.40(0.16)$ & $\mathbf{- 0 . 8 8}(0.93)$ \\
\hline
\end{tabular}




\subsection{Discussion}

Our fine root inventory in three common saltmarsh communities at two geomorphologically different saltmarsh sites clearly showed differences in fine root mass between the three saltmarsh communities across the elevational gradient, but also between the two sites. At both study sites, the greatest fine root mass was recorded in the lower salt marsh, which correlated with highest plant diversity in these communities, where Atriplex portulacoides co-existed with about 10 other herb and grass species. We assume that in this lower saltmarsh community, a considerable diversity of below-ground space occupation strategies exists, as annuals (Salicornia spp.), small herbs (Spergularia media), tall herbs (e.g. Aster tripolium, Triglochin maritima), grasses (Puccinellia maritima, Spartina anglica, Festuca rubra) and dwarf shrubs (Atriplex portulacoides) share the rooted soil volume and likely partition space as explained by the 'complementarity effect' (Loreau and Hector 2001). In contrast, the upper saltmarsh community is nearly exclusively occupied by dense stands of Elytrigia atherica, and the pioneer zone is largely dominated by Spartina anglica with only low cover of additional grasses or herbs, which leaves less room for root space partitioning. This positive correlation between diversity and fine root mass in agreement with our hypothesis (iv) matches results from other root studies in salt marshes and other ecosystems and indicates an existing effect of biodiversity (Cardinale et al. 2006; Hooper et al. 2005). For example, Ford et al. (2016) found plant species richness to be a significant predictor of root biomass in a salt marsh in the UK. Similarly, in the mesocosm experiment of Sullivan et al. (2007) with various saltmarsh species, a significant increase in root biomass and also in the root:shoot ratio was recorded with increasing species diversity. These different reports suggest that plant diversity is a driver of fine root mass in temperate saltmarsh communities, in agreement with the findings in other non-saline grassland habitats (Weisser et al. 2017; Eisenhauer et al. 2017; Mommer et al. 2010; Mueller et al. 2013).

The lower saltmarsh zone plays a crucial role for sediment trapping and stabilization in the foreland bordering dykes and islands along the north-west European Wadden Sea coast. Our root data suggest that the relatively species-rich communities with abundant $A$. portulacoides are effective sediment stabilizers, since plant diversity was found to increase root density. This matches the observation that plant species richness enhances soil stability and erosion protection in salt marshes and other grasslands (Chen et al. 2012; Coops et al. 1996; Gould et al. 2016). Supporting previous studies (Chen et al. 2012), we suggest that A. portulacoides plays a role as key species in stabilizing sediment by its extensive root system in ungrazed saltmarsh sites.

The multiple regression analysis and the direct comparison of the three community types (zones) and two sediment types (sites) suggest that the principal abiotic factors salinity and inundation frequency 
only have a relatively small influence on fine root mass. The Na content of the sediment as a proxy of inundation duration showed a positive (though relatively weak) influence on root mass in the total sample (and in Westerhever), and root mass and root density reached a minimum in the upper marsh of both sites, where the exposure to salinity and inundation was lowest. This pattern is best explained by a dominant effect of plant species identity and species richness on community fine root mass, while effects of salinity (and anoxia) are diminished by effective adaptation of the species. It appears that productive species like $S$. anglica and A. portulacoides with specific adaptations to salinity and anoxia replace less adapted species in the lower marsh and pioneer zone, where they are capable of establishing large root systems. The photosynthesis of the C4 grass Spartina is rarely limited by salinity (Longstreth and Strain 1977) and the species is capable of oxidizing sulfide in the roots and rhizosphere by means of effective $\mathrm{O}_{2}$ transport to the sediment through its aerenchyma (Lee 1999; Lee 2003; Maricle and Lee 2002). Therefore, S. anglica is a highly productive species (exceeding $6000 \mathrm{~g} \mathrm{~d} . \mathrm{m} . \mathrm{m}^{-2} \mathrm{yr}^{-1}$; Long and Woolhouse 1979) despite the mostly anoxic sediment. A. portulacoides is also highly tolerant of salinity (Redondo-Gómez et al. 2007) which is due to the accumulation of quaternary ammonium compounds for osmoregulation (Stewart and Lee 1974; Rozema et al. 1985). The effective adaptation of the pioneer zone species (and also of the lower marsh zone taxa) to the adverse conditions in this environment is also reflected in a higher proportion of root mass (31-35\%) in the subsoil (20-40 cm depth) of the pioneer zone compared to the upper salt marsh (17-19\%). This is in accordance with our hypothesis (ii) in which we postulated a deeper root system in the more frequently inundated pioneer zone with well-adapted species. Interestingly, there was a great difference in fine root density between sites at $10 \mathrm{~cm}$ soil depth (Fig. 3.4). It may be speculated that the very high fine root density in this soil depth found at Spiekeroog is related to the soil texture and associated lower plant-available $\mathrm{P}$ concentrations in the soil which may lead to a species-specific increase in fine root mass (assumedly by A. portulacoides) to compensate for limited $\mathrm{P}$ in the lower salt marsh. An earlier study by Strieckmann (1989, unpubl. data; Supplementary Material 4) also found no root density decrease down to $24 \mathrm{~cm}$ depth in other north German $S$. anglica marshes. In contrast, the fine root density decrease from the topsoil to $20-40 \mathrm{~cm}$ was significant in the upper salt marsh of both sites, indicating that E. atherica is more sensitive to waterlogging (Veeneklaas et al. 2013; Schröder et al. 2002; Armstrong et al. 1985) and thus develops a shallower distribution of fine roots.

Our data also suggest that higher nutrient availability tends to reduce fine root mass, as it was postulated in our first hypothesis. Fine root mass was higher by roughly $25 \%$, and root area index even by about $50 \%$ in the sandy Spiekeroog plots compared to the silt- and clay-rich Westerhever plots. This may indicate that the plants in the sandy sediment need to produce larger root systems, 
with especially large surface area, to compensate for the generally lower concentrations of plantavailable nutrients found in the sandy sediments of the Spiekeroog salt marsh. Sediment stability might also be responsible for differences in fine root mass: a higher root mass in the sandy Spiekeroog sediments could be required for plant anchorage, as fine-grained clay soils resist erosion better than sandy soils (van Eerdt 1985; Allen 1989). Since bulk density was higher at the sandy Spiekeroog site providing less air and water space, and less space for root proliferation, especially in the deeper soil horizon, it may be assumed that the need of fine roots for nutrient capture and plant stability exceeds the disadvantages for root growth in soil with higher bulk density, furthermore indicating the good adaptation of roots to the abiotic conditions.

Comparison of our fine root mass data to other studies on below-ground biomass in salt marshes is limited due to several reasons. First, it has to be kept in mind that we measured total fine root mass and not fine root biomass, even though our figures should be close to biomass according to our live:dead ratio assessment under the microscope in a number of subsamples. While a few authors explicitly sampled only fine root biomass, various studies do not state, whether live and dead roots were separated, and the term 'biomass' is sometimes used for total root mass (biomass + necromass), which makes comparison to other studies difficult. Second, other authors used different criteria for defining root mass or biomass, sometimes including coarse roots and rhizomes as well, or retrieving root mass with sieves of greater mesh size than we did. This will increase or decrease root biomass figures, thus leading to deviating results. Groenendijk and Vinklievaart (1987) investigated total below-ground biomass in $0-60 \mathrm{~cm}$ in a Dutch salt marsh and obtained much higher profile totals than we did, which may only be partly explained by the lower profile depth investigated in our study (0-40 $\mathrm{cm})$. Nevertheless, the same root mass distribution patterns along the saltmarsh elevational gradient became visible in the Dutch study: Greatest below-ground biomass totals were recorded in the $A$. portulacoides-dominated lower marsh (mean: 13,338 $\mathrm{g} \mathrm{m}^{-2}$ ), while the lowest biomass occurred in the upper marsh dominated by E. atherica (mean: $7763 \mathrm{~g} \mathrm{~m}^{-2}$ ). On the North Sea coast of England, Ford et al. (2016) reported at six saltmarsh sites lower root biomass totals (1500 to $8800 \mathrm{~g} \mathrm{~m}^{-2}$ to $30 \mathrm{~cm}$ soil depth) than found in the Netherlands. Comparison of our data from the S. anglica stands at our study sites (site means of 1500-2000 $\mathrm{g} \mathrm{m}^{-2}$ ) with data from Spartina alterniflora-dominated salt marshes on the east coast of the United States indicates a similar root biomass average, but larger variation among sites (600 to 11,000 $\mathrm{g} \mathrm{m}^{-2}$; Tripathee and Schaefer 2015; Smith et al. 1979; Windham et al. 2003). Unpublished root biomass data from a grazed and an ungrazed salt marsh in Schleswig-Holstein (Germany) of Strieckmann (1989, unpublished) range between 1000 and $5000 \mathrm{~g} \mathrm{~m}^{-2}$ for the profile to $24 \mathrm{~cm}$ (Table 3.6, Supplementary Material 4). In contrast to our study, the greatest below-ground biomass in the ungrazed site was recorded in the plots dominated by S. anglica and A. tripolium, 
while the minimum $\left(\sim 1500 \mathrm{~g} \mathrm{~m}^{-2}\right)$ occurred in the A. portulacoides stands. Similar to our plots in Westerhever, the upper saltmarsh community with E. atherica dominance was the only stand with a root biomass:aboveground biomass ratio $<1$ (Table 3.6).

Table 3.6: Compilation of root mass and above-ground biomass data from North Sea salt marshes up to a sediment depth of $20 \mathrm{~cm}$ from this study and for two further sites investigated by Strieckmann (1989).

\begin{tabular}{|c|c|c|c|c|c|}
\hline Study site & $\begin{array}{c}\text { Dominant } \\
\text { plant species }\end{array}$ & $\begin{array}{l}\text { Root mass } \\
\left(\mathrm{g} \mathrm{m}^{-2}\right)\end{array}$ & $\begin{array}{c}\text { Above-ground } \\
\text { biomass }\left(\mathrm{g} \mathrm{m}^{-2}\right)\end{array}$ & Methodology & Reference \\
\hline \multirow{3}{*}{$\begin{array}{l}\text { Spiekeroog, } \\
\text { Germany } \\
\text { (ungrazed } \\
\text { marsh) }\end{array}$} & S. anglica & $1503 \pm 331$ & $1048 \pm 205$ & \multirow{6}{*}{$\begin{array}{l}\text { Size of sieve for root } \\
\text { washing: } 200 \mu \mathrm{m} \text {; } \\
\text { Soil depth: } 20 \mathrm{~cm} \text {; } \\
\text { only fine roots (dead } \\
\text { and alive); } \\
\text { sampling in } \\
\text { September; } \\
\text { mean } \pm \text { se } \\
\text { presented }\end{array}$} & \multirow{6}{*}{ This study } \\
\hline & A. portulacoides & $2243 \pm 484$ & $712 \pm 210$ & & \\
\hline & E. atherica & $1296 \pm 111$ & $481 \pm 37$ & & \\
\hline \multirow{3}{*}{$\begin{array}{l}\text { Westerhever, } \\
\text { Germany } \\
\text { (ungrazed } \\
\text { marsh) }\end{array}$} & S. anglica & $888 \pm 123$ & $1134 \pm 159$ & & \\
\hline & A. portulacoides & $1469 \pm 332$ & $2376 \pm 329$ & & \\
\hline & E. atherica & $617 \pm 46$ & $1685 \pm 387$ & & \\
\hline \multirow{5}{*}{$\begin{array}{l}\text { Oland, } \\
\text { Germany } \\
\text { (ungrazed } \\
\text { marsh) }\end{array}$} & S. anglica & 2594 & $235 \pm 146$ & \multirow{8}{*}{$\begin{array}{l}\text { Size of sieve for root } \\
\text { washing: } 315 \mu \mathrm{m} \text {; } \\
\text { soil depth: } 24 \mathrm{~cm} \text {; } \\
\text { no differentiation } \\
\text { between root } \\
\text { fractions; } \\
\text { sampling in June; } \\
\text { mean } \pm \text { sd presented }\end{array}$} & \multirow{8}{*}{$\begin{array}{c}\text { Strieckmann } \\
\text { (1989), } \\
\text { unpublished } \\
\text { data }\end{array}$} \\
\hline & $\begin{array}{l}\text { S. anglica }+ \\
\text { A. tripolium }\end{array}$ & 5156 & $783 \pm 179$ & & \\
\hline & S. anglica & 3967 & $778 \pm 184$ & & \\
\hline & A. portulacoides & 1661 & $1191 \pm 916$ & & \\
\hline & E. atherica & 1712 & $2178 \pm 281$ & & \\
\hline \multirow{3}{*}{$\begin{array}{l}\text { Sönke- } \\
\text { Nissen-Koog, } \\
\text { Germany } \\
\text { (grazed } \\
\text { marsh) }\end{array}$} & P. maritima & 3496 & $518 \pm 83$ & & \\
\hline & P. maritima & 2148 & $486 \pm 164$ & & \\
\hline & S. anglica & 2743 & $499 \pm 171$ & & \\
\hline
\end{tabular}

The fact that we considered only fine roots $(<2 \mathrm{~mm}$ in diameter $)$ and not coarse roots and rhizomes, may explain differences in root biomass totals among different studies in Spartina marshes. For example, Darby and Turner (2008) found a mean root biomass of $753 \mathrm{~g} \mathrm{~m}^{-2}$, but a mean rhizome biomass of $1952 \mathrm{~g} \mathrm{~m}^{-2}$ of $S$. alterniflora in a Louisiana salt marsh, matching findings of Schubauer and Hopkinson (1984). Data of total belowground biomass (including larger root diameters) are important for carbon cycle studies, but less informative when the below-ground absorptive surface of plants and communities is assessed. Several studies indicate that the standing fine root biomass (or 
mass) in salt marshes varies considerably with season (Steinke et al. 1996; Darby and Turner 2008; Groenendijk and Vinklievaart 1987), which may also explain differences between studies.

In our study, we did not distinguish between dead and live fine roots, as we found the proportion of dead fine roots to be low $(<10 \%)$ in all inspected samples. Similar live:dead ratios were reported by Groenendijk and Vinklievaart (1987) in a Dutch salt marsh ( $<15 \%$ non-living roots), while the proportion of below-ground necromass was greater in certain North American salt marshes, exceeding root biomass (Darby and Turner 2008; Valiela et al. 1976; Schubauer and Hopkinson 1984). Apart from differences in the root diameter considered and likely variance in root mortality rates, this may be a consequence of slow root decomposition rates as was found in a Dutch salt marsh (Buth 1987). Direct observation of fine root dynamics with rhizoscopes may be needed to unravel the causes of different root live:dead ratios in anoxic sediments.

A comparison of the fine root mass of salt marshes with that of other grassland or herbaceous communities indicates that the multi-stress conditions in this saline environment demand for high carbohydrate investment in below-ground organs by the plants. According to root mass data compiled by Leuschner and Ellenberg (2017), non-saline mesic to moist temperate grasslands have root masses in the topsoil (mostly $0-15 \mathrm{~cm}$ ) of $500-2000 \mathrm{~g} \mathrm{~m}^{-2}$ matching the root mass figures of our upper salt marsh, while being smaller than the root masses found in the lower marsh and the pioneer zone. Jackson et al. (1997) give a global fine root mass mean of $1510 \mathrm{~g} \mathrm{~m}^{-2}$ for temperate grasslands, which is also lower than the root masses found in our lower salt marsh and in other Spartina stands in the northern hemisphere. Similarly, our root surface area totals (RAI values $>300 \mathrm{~m}^{2} \mathrm{~m}^{-2}$ ) were several times larger than the mean RAI recorded for temperate grasslands by Jackson et al. (1997) $\left(79.1 \mathrm{~m}^{2} \mathrm{~m}^{-2}\right)$.

One might expect that the substantial variation in inundation frequency, sediment anoxia and salinity found in the different saltmarsh zones of Spiekeroog and Westerhever should lead to pronounced differences in fine root morphology in the different communities (hypothesis iii). Bouma et al. (2003) hypothesized that the saltmarsh plants of the pioneer zone have slower-growing, more stress-tolerant roots, while the plants of the upper salt marsh should be faster growing, which might result in a higher root tissue density of the former. We found elevated tissue densities in both the upper marsh and the pioneer zone of the Westerhever site, but no difference across the Spiekeroog gradient and thus no consistent root tissue density pattern in our study. Similarly, community differences in SRL and SRA were not consistent across the two elevational gradients; mean fine root diameter was remarkably constant in our samples. We conclude from these inconsistent patterns that fine root morphology is largely under the control of plant species and their specific adaptations to the adverse conditions (i.e. the formation of aerenchyma), while a more general pattern of root morphology did 
not emerge in the studied saltmarsh communities. This contradicts hypothesis (iii) but matches the findings of Bouma et al. (2001 and 2003) of an only weak responsiveness of the root architecture of three halophytic grass species to nitrogen supply, inundation and oxygen content of the sediment and no relationship between root longevity and tissue density. Root $\mathrm{N}$ concentration peaked at both sites in the lower salt marsh, possibly reflecting species-specific $\mathrm{N}$ uptake patterns.

\section{Conclusions}

Our study in two salt marshes with contrasting geomorphology shows that fine root mass is relatively high and fine root surface area large in comparison to grassland ecosystems in terrestrial habitats. The plants of the frequently inundated lower marsh and pioneer zone seem to be well adapted to this stressful environment, allowing some specialist species such as Spartina to establish a root system with deep penetration of the sediment for good anchorage and nutrient supply. These adaptations of characteristic species appear to control the fine root mass of the saltmarsh communities, overriding effects of environmental stress. As in other habitats with extreme environmental conditions, a higher number of plant species tends to increase root biomass and seems to promote soil exploration through root space partitioning by functionally different species. Studies on fine root dynamics and root function in terms of water and nutrient uptake are needed for a mechanistic understanding of the below-ground compartment of saltmarsh communities and its sensitivity to environmental change.

\section{Acknowledgements}

We would like to thank the administrations of the Lower Saxony and Schleswig-Holstein Wadden Sea National Parks for giving permission for study and allowing access to the field sampling sites. Special thanks go to Dr. Martin Stock for giving an on-site introduction in Westerhever and providing various data. Many thanks also to Till Montag for help with processing of the fine root samples and to Daniela Meier for providing data on water levels at Spiekeroog. Tide gauge data for Westerhever were provided by the Schleswig-Holstein Agency for Coastal Protection, National Park and Marine Conservation (Husum). This work was part of the joint research project "BEFmate" (Biodiversity and Ecosystem Functioning across marine and terrestrial ecosystems) funded by the Ministry for Science and Culture of Lower Saxony, Germany, under project number ZN2930. Financial support is gratefully acknowledged. 


\subsection{Supplementary Material}

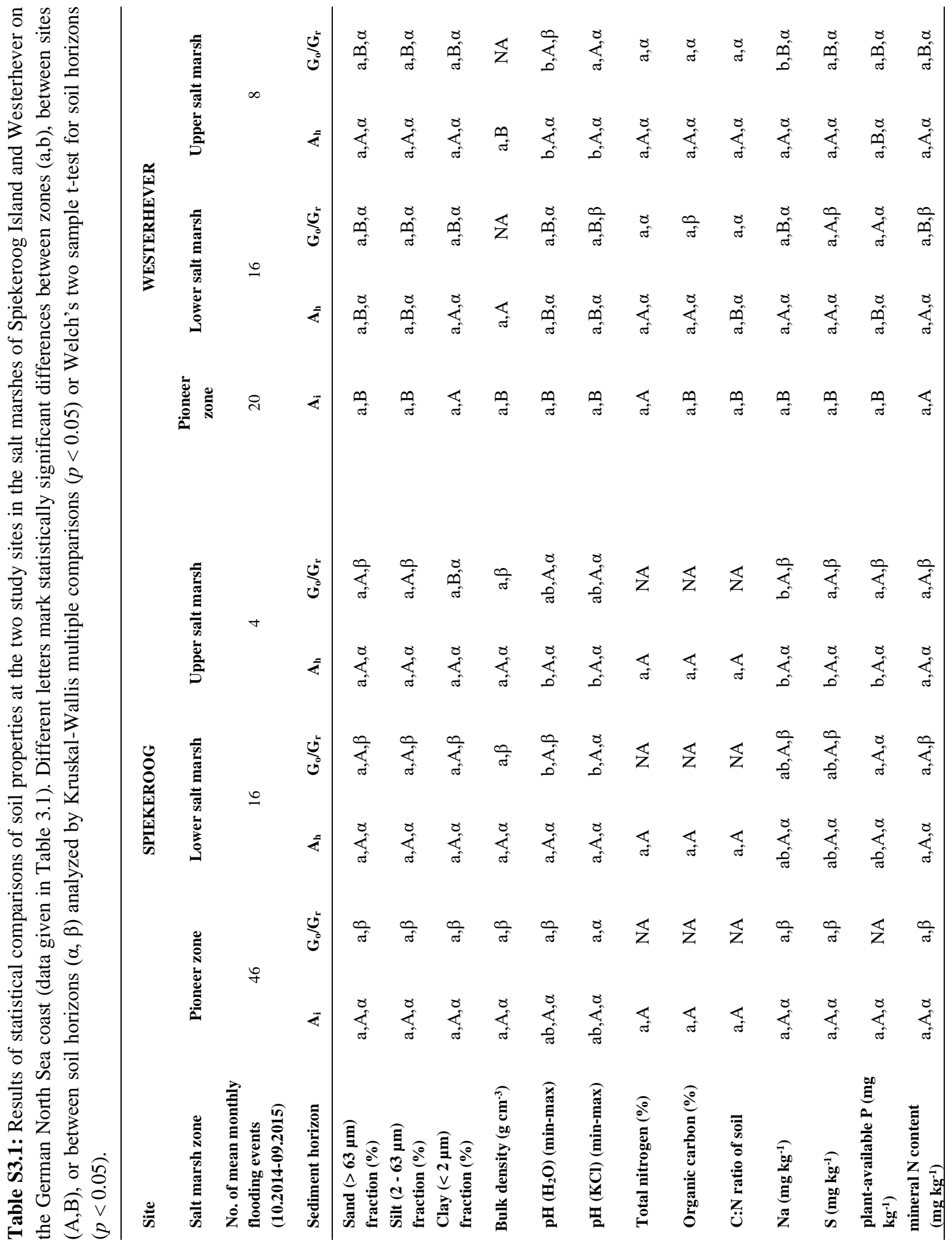




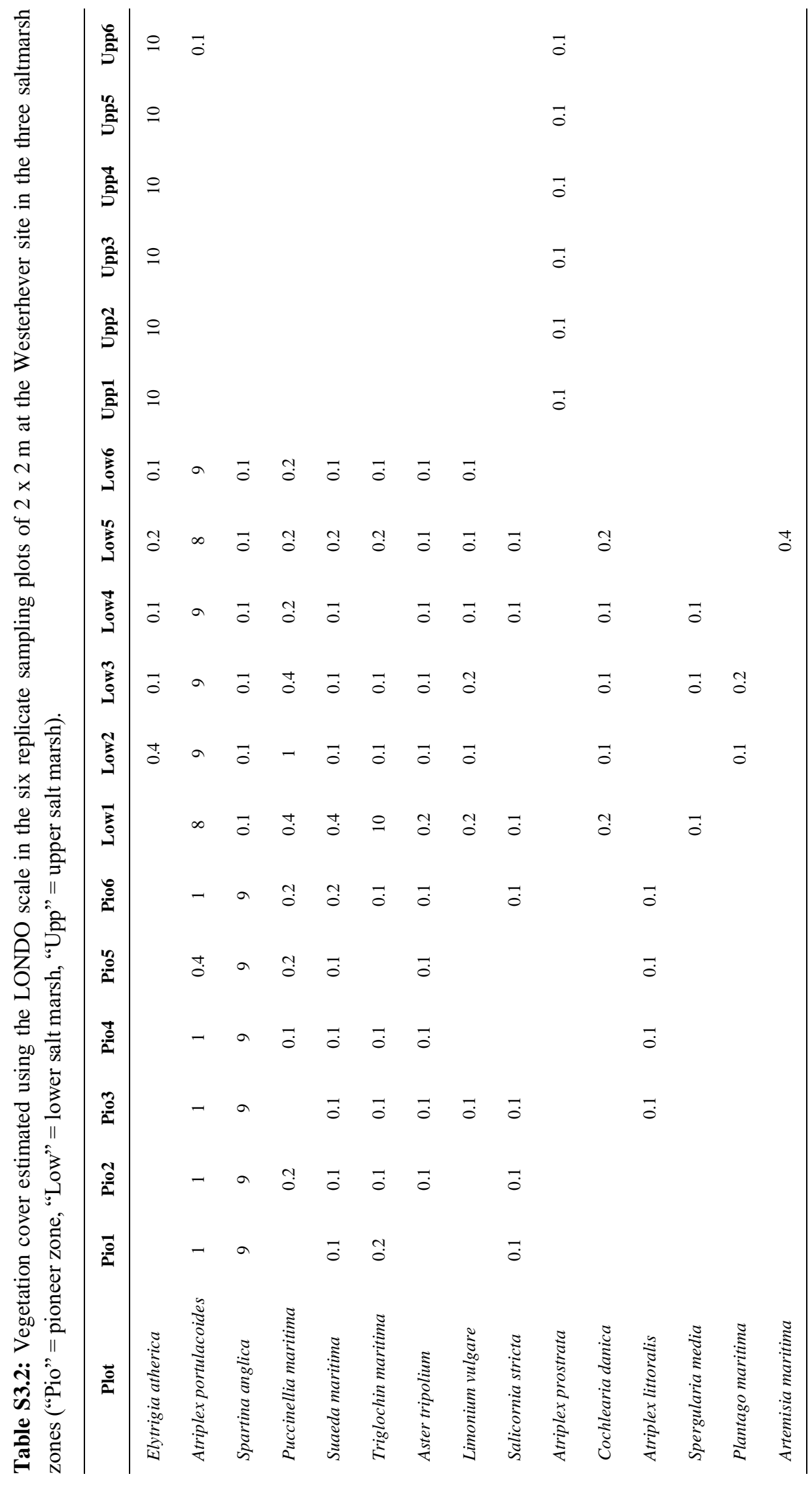




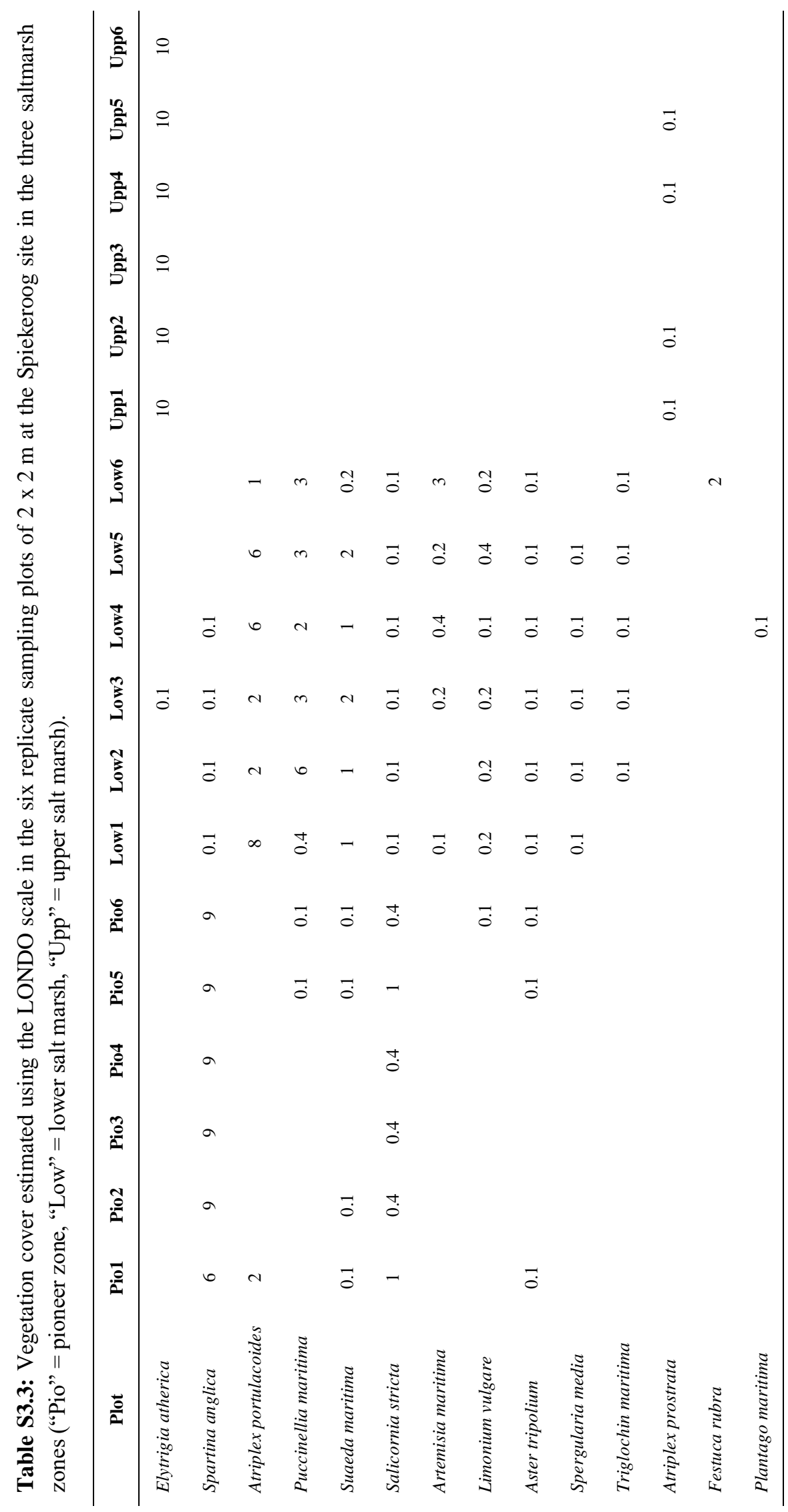




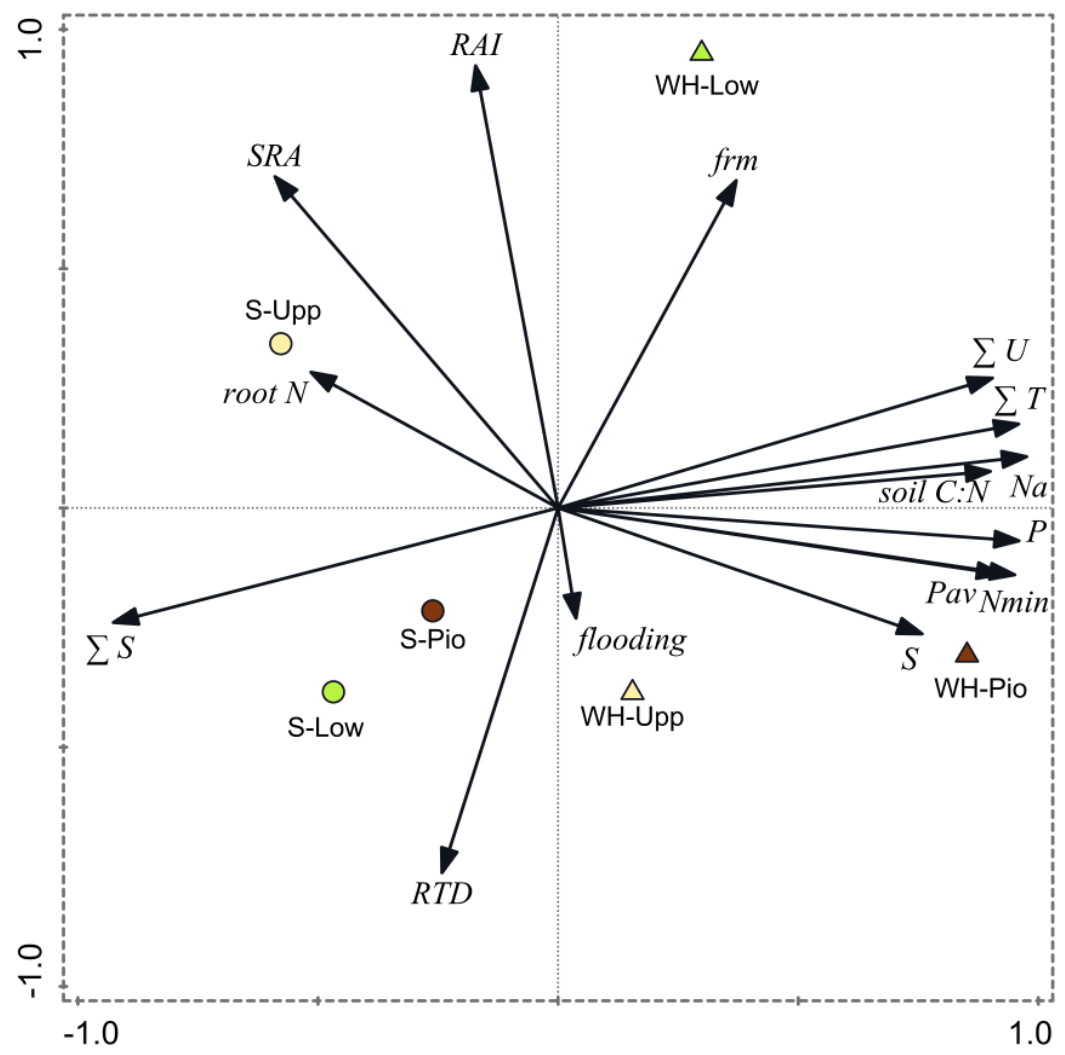

Figure S3.1: Plot showing the distribution of the three saltmarsh zones (Pio, Low and Upp) in the two saltmarsh sites Spiekeroog (S) and Westerhever (WH) in PCA axes 1 and 2 with soil and root properties (SRA: specific root area, $\sum \mathrm{T}$ : clay fraction, RAI: root area index, FRM: fine root mass, root $\mathrm{N}$ : root $\mathrm{N}$ concentration, $\sum S$ : sand fraction, H: Shannon-Wiener index, Na: Na concentration in soil, flooding: monthly flooding events, P: total P in soil, Pav: plant-available P in soil, RTD: root tissue density, $\sum \mathrm{U}$ : silt fraction, Nmin: mineral N $\left(\mathrm{NO}_{3}{ }^{-}\right.$and $\left.\mathrm{NH}_{4}{ }^{+}\right)$in soil) related to the deeper soil horizon $\left(\mathrm{G}_{\mathrm{o}} / \mathrm{G}_{\mathrm{r}}\right)$. Vector length and angle are proportional to the direction and degree of their correlation with the plot ordination scores. 
Table S3.4: Results of a Principal Components Analysis (PCA) on the differentiation of the 3 saltmarsh zones at both study sites with respect to fine root mass, root morphological traits, species diversity and soil properties of the Go/Gr horizon. Given are the loadings of the selected variables along the first three explanatory axes. Numbers in brackets below the axes indicate the eigenvalues (EV) of the axes. Numbers in bold mark the variables with closest correlation to the respective axis (cumulative fit values are given in brackets).

\begin{tabular}{lccc}
\hline & $\begin{array}{c}\text { Axis 1 } \\
\text { (EV 0.5633) }\end{array}$ & $\begin{array}{c}\text { Axis 2 } \\
\text { (EV 0.1873) }\end{array}$ & $\begin{array}{c}\text { Axis 3 } \\
\text { (EV 0.1430) }\end{array}$ \\
\hline fine root mass & $0.38(0.14)$ & $\mathbf{0 . 7 8}(0.61)$ & $0.55(0.91)$ \\
specific root area & $-0.59(0.35)$ & $\mathbf{0 . 6 9}(0.83)$ & $-0.30(0.92)$ \\
root tissue density & $-0.24(0.06)$ & $\mathbf{- 0 . 7 6}(0.64)$ & $-0.28(0.72)$ \\
root N concentration & $-0.51(0.26)$ & $0.28(0.35)$ & $-0.32(0.45)$ \\
root surface area & $-0.17(0.03)$ & $\mathbf{0 . 9 2}(0.88)$ & $0.24(0.94)$ \\
total Na in soil & $\mathbf{0 . 9 8}(0.95)$ & $0.11(0.96)$ & $0.05(0.97)$ \\
total P in soil & $\mathbf{0 . 9 6}(0.92)$ & $-0.07(0.93)$ & $-0.10(0.94)$ \\
total S in soil & $\mathbf{0 . 7 6}(0.57)$ & $-0.26(0.64)$ & $\mathbf{0 . 5 9}(0.99)$ \\
C:N ratio in soil & $\mathbf{0 . 9 0}(0.81)$ & $0.08(0.82)$ & $-0.13(0.83)$ \\
plant available P & $\mathbf{0 . 9 2}(0.85)$ & $-0.14(0.87)$ & $-0.12(0.89)$ \\
plant available N & $\mathbf{0 . 9 5}(0.90)$ & $-0.14(0.92)$ & $-0.11(0.93)$ \\
$\sum$ Sand & $\mathbf{- 0 . 9 3}(0.86)$ & $-0.24(0.92)$ & $0.25(0.97)$ \\
$\sum$ Silt & $\mathbf{0 . 9 0}(0.82)$ & $0.27(0.89)$ & $-0.27(0.96)$ \\
$\sum$ Clay & $\mathbf{0 . 9 6}(0.92)$ & $0.18(0.95)$ & $-0.20(0.99)$ \\
flooding & $0.04(0.00)$ & $-0.23(0.05)$ & $\mathbf{0 . 9 7}(0.99)$ \\
\hline
\end{tabular}



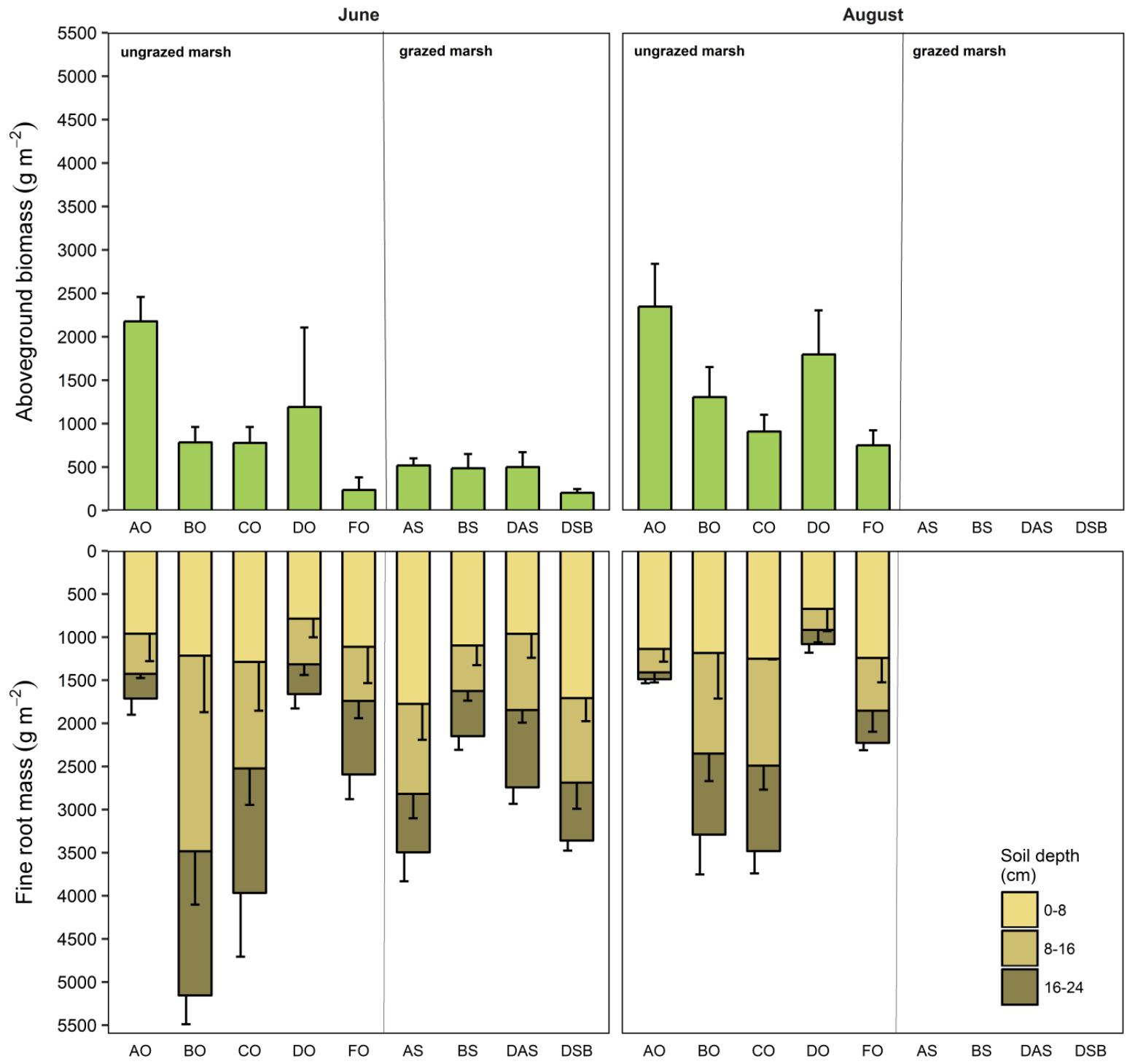

Figure S3.2: Above-ground vs. below-ground (fine root) biomass (dry weight) at nine plots in two saltmarsh sites (means $\pm \mathrm{SD}, \mathrm{n}=4-6$ ). Plot names with an "O" are located in an ungrazed salt marsh on the Hallig island Oland, plot names with an "S" are located in a grazed salt marsh at Sönke-Nissen-Koog (both are located in Schlswig-Holstein, Germany). The first letter of the plot name refers to the plant community: "AO": Elytrigia atherica dominated (Oland), "BO": Spartina anglica with Aster tripolium (Oland), "CO": Spartina anglica dominated Oland, "DO": Atriplex portulacoides dominated (Oland), "FO": Spartina anglica dominated Oland, "AS" Spartina anglica dominated (Sönke-Nissen-Koog), "BS": Puccinellia maritima dominated (Sönke-NissenKoog), "DAS": Spartina anglica dominated at a scoured location (Sönke-Nissen-Koog), "DSB": Puccinellia maritima dominated on an elevated location (Sönke-Nissen-Koog). Data collected by Rita Strieckmann (1989, unpublished). 


\section{References}

Allen JR (1989) Evolution of salt-marsh cliffs in muddy and sandy systems: a qualitative comparison of British west-coast estuaries. Earth Surface Processes and Landforms 14:85-92.

Armstrong W, Wright EJ, Lythe S, Gaynard TJ (1985) Plant zonation and the effects of the springneap tidal cycle on soil aeration in a humber salt-marsh. Journal of Ecology 73:323-339.

Bakker JP (2014) Ecology of salt marshes. 40 years of research in the Wadden Sea. Wadden Academy.

Bouchard V, Lefeuvre JC (2000) Primary production and macro-detritus dynamics in a European salt marsh: carbon and nitrogen budgets. Aquatic Botany 67:23-42.

Bouma TJ, Hengst K, Koutstaal BP, van Soelen J (2002) Estimating root lifespan of two grasses at contrasting elevation in a salt marsh by applying vitality staining on roots from in-growth cores. Plant Ecology 165:235-245.

Bouma TJ, Koutstaal BP, van Dongen M, Nielsen KL (2001) Coping with low nutrient availability and inundation: root growth responses of three halophytic grass species from different elevations along a flooding gradient. Oecologia 126:472-481. doi:10.1007/s004420000545.

Buth GJ (1987) Decomposition of roots of three plant communities in a Dutch salt marsh. Aquatic Botany 29:123-138.

Cardinale BJ, Srivastava DS, Duffy JE, Wright JP, Downing AL, Sankaran M, Jouseau C (2006) Effects of biodiversity on the functioning of trophic groups and ecosystems. Nature 443:989-992. doi:10.1038/nature05202.

Cardinale BJ, Wright JP, Cadotte MW, Carroll IT, Hector A, Srivastava DS, Loreau M, Weis JJ (2007) Impacts of plant diversity on biomass production increase through time because of species complementarity. Proceedings of the National Academy of Sciences of the United States of America 104:18123-18128. doi:10.1073/pnas.0709069104.

Chen Y, Thompson CEL, Collins MB (2012) Saltmarsh creek bank stability: Biostabilisation and consolidation with depth. Continental Shelf Research 35:64-74. doi:10.1016/j.csr.2011.12.009.

Cooper A (1982) The effects of salinity and waterlogging on the growth and cation uptake of salt marsh plants. New Phytologist 90:263-275.

Coops H, Geilen N, Verheij HJ, Boeters R, van der Velde G (1996) Interactions between waves, bank erosion and emergent vegetation: An experimental study in a wave tank. Aquatic Botany 53:187198.

Darby FA, Turner RE (2008) Below- and aboveground Spartina alterniflora production in a Louisiana salt marsh. Estuaries and Coasts 31:223-231. doi:10.1007/s12237-007-9014-7.

Eisenhauer N, Lanoue A, Strecker T, Scheu S, Steinauer K, Thakur MP, Mommer L (2017) Root biomass and exudates link plant diversity with soil bacterial and fungal biomass. Scientific Reports 7:44641. doi:10.1038/srep44641. 
Ford H, Garbutt A, Ladd C, Malarkey J, Skov MW (2016) Soil stabilization linked to plant diversity and environmental context in coastal wetlands. Journal of Vegetation Science 27:259-268. doi:10.1111/jvs.12367.

Gill RA, Jackson RB (2000) Global patterns of root turnover for terrestrial ecosystems. New Phytologist 147:13-31. doi:10.1046/j.1469-8137.2000.00681.x.

Gould IJ, Quinton JN, Weigelt A, Deyn GB de, Bardgett RD, Seabloom E (2016) Plant diversity and root traits benefit physical properties key to soil function in grasslands. Ecology letters 19:11401149. doi:10.1111/ele.12652.

Groenendijk AM, Vinklievaart MA (1987) Primary production and biomass on a Dutch salt-marsh emphasis on the belowground component. Vegetatio 70:21-27.

Heinrichs H, Brumsack HJ, Loftfield N, König N (1986) Verbessertes Druckaufschlußsystem für biologische und anorganische Materialien. Zeitschrift für Pflanzenernährung und Bodenkunde 149:350-353.

Hertel D, Leuschner C (2002) A comparison of four different fine root production estimates with ecosystem carbon balance data in a Fagus-Quercus mixed forest. Plant and Soil 239:237-251.

Hooper DU, Chapin FS, Ewel JJ, Hector A, Inchausti P, Lavorel S, Lawton JH, Lodge DM, Loreau M, Naeem S, Schmid B, Setala H, Symstad AJ, Vandermeer J, Wardle DA (2005) Effects of biodiversity on ecosystem functioning: A consensus of current knowledge. Ecological Monographs 75:3-35.

Jackson RB, Canadell J, Ehleringer JR, Mooney HA, Sala OE, Schulze ED (1996) A global analysis of root distributions for terrestrial biomes. Oecologia 108:389-411. doi:10.1007/BF00333714.

Jackson RB, Mooney HA, Schulze E-D (1997) A global budget for fine root biomass, surface area, and nutrient contents. Proceedings of the National Academy of Sciences 94:7362-7366. doi:10.1073/pnas.94.14.7362.

Kiehl K, Esselink P, Bakker JP (1997) Nutrient limitation and plant species composition in temperate salt marshes. Oecologia 111:325. doi:10.1007/s004420050242.

Lee RW (1999) Oxidation of sulfide by Spartina alterniflora roots. Limnology and Oceanography 44:1155-1159.

Lee RW (2003) Physiological adaptations of the invasive cordgrass Spartina anglica to reducing sediments. Rhizome metabolic gas fluxes and enhanced $\mathrm{O}_{2}$ and $\mathrm{H}_{2} \mathrm{~S}$ transport. Marine Biology 143:9-15. doi:10.1007/s00227-003-1054-3.

Leuschner C, Ellenberg H (2017) Ecology of Central European Non-Forest Vegetation: Coastal to Alpine, Natural to Man-Made Habitats. Vegetation Ecology of Central Europe Volume II. Chapter 1: Salt Marshes and Inland Saline Habitats. Springer Nature, Cham.

Leuschner C, Gebel S, Rose L (2013) Root trait responses of six temperate grassland species to intensive mowing and NPK fertilisation. A field study in a temperate grassland. Plant and Soil 373:687-698. doi:10.1007/s11104-013-1836-4. 
Levine JM, Brewer JS, Bertness MD (1998) Nutrients, competition and plant zonation in a New England salt marsh. Journal of Ecology 86:285-292.

Long SP, Woolhouse HW (1979) Primary production in Spartina marshes. In: Jefferies RL, Davy AJ (eds) Ecological Processes in Coastal Environments. Blackwell, Oxford:33-352.

Longstreth DJ, Strain BR (1977) Effects of salinity and illumination on photosynthesis and water balance of Spartina alterniflora Loisel. Oecologia 31:191-199.

Loreau M, Hector A (2001) Partitioning selection and complementarity in biodiversity experiments. Nature 412:72-76. doi:10.1038/35083573.

Maricle BR, Lee RW (2002) Aerenchyma development and oxygen transport in the estuarine cordgrasses Spartina alterniflora and S. anglica. Aquatic Botany 74:109-120.

Mommer L, van Ruijven J, Caluwe $\mathrm{H}$ de, Smit-Tiekstra AE, Wagemaker CAM, Ouborg NJ, Bogemann GM, van der Weerden GM, Berendse F, Kroon H de (2010) Unveiling below-ground species abundance in a biodiversity experiment: a test of vertical niche differentiation among grassland species. Journal of Ecology 98:1117-1127. doi:10.1111/j.1365-2745.2010.01702.x.

Mueller KE, Tilman D, Fornara DA, Hobbie SE (2013) Root depth distribution and the diversityproductivity relationship in a long-term grassland experiment. Ecology 94:787-793.

Peiter A (2004) GIS-gestützte Auswertung von Monitoringdaten am Beispiel einer Habitatanalyse für Nonnengänse (Branta leucopsis) und Ringelgänse (Branta bernicla) in der Salzwiese Westerhever. Diploma Thesis. University of Vechta.

R Development Core Team (2016) R: A Language and Environment for Statistical Computing. R Foundation for Statistical Computing, Vienna, Austria, https://www.R-project.org/.

Redondo-Gómez S, Mateos-Naranjo E, Davy AJ, Fernandez-Munoz F, Castellanos EM, Luque T, Figueroa ME (2007) Growth and photosynthetic responses to salinity of the salt-marsh shrub Atriplex portulacoides. Annals of Botany 100:555-563. doi:10.1093/aob/mcm119.

Rozema J, Bijwaard P, Prast G, Broekman R (1985) Ecophysiological adaptations of coastal halophytes from foredunes and salt marshes. Vegetatio 62:499-521.

Rozema J, Gude H, Pollak G (1981) An ecophysiological study of the salt secretion of 4 halophytes. New Phytologist 89:201-217.

Schröder HK, Kiehl K, Stock M (2002) Directional and non-directional vegetation changes in a temperate salt marsh in relation to biotic and abiotic factors. Applied Vegetation Science 5:33-44. doi:10.1658/1402-2001(2002)005[0033:DANDVC]2.0.CO;2.

Schubauer JP, Hopkinson CS (1984) Above- and belowground emergent macrophyte production and turnover in a coastal marsh ecosystem, Georgia. Limnology and Oceanography 29:1052-1065. doi:10.4319/lo.1984.29.5.1052.

Schüller H (1969) Die CAL-Methode, eine neue Methode zur Bestimmung des pflanzenverfügbaren Phosphates in Böden. Zeitschrift für Pflanzenernährung und Bodenkunde 123:48-63. doi:10.1002/jpln.19691230106. 
Smith KK, Good RE, Good NF (1979) Production dynamics for above and belowground components of a New Jersey Spartina alterniflora tidal marsh. Estuarine and Coastal Marine Science 9:189201.

Steinke W, Willert DJ von, Austenfeld FA (1996) Root dynamics in a salt marsh over three consecutive years. Plant and Soil 185:265-269. doi:10.1007/BF02257532.

Steudel B, Hautier Y, Hector A, Kessler M (2011) Diverse marsh plant communities are more consistently productive across a range of different environmental conditions through functional complementarity. Journal of Applied Ecology 48:1117-1124. doi:10.1111/j.13652664.2011.01986.x.

Stewart GR, Lee JA (1974) The role of proline accumulation in halophytes. Planta 120:279-289. doi:10.1007/BF00390296.

Stock M (2012) TMAP Wadden Sea Sedimentation Database. Vegetation databases for the $21^{\text {st }}$ century. Biodiversity and Ecology:372.

Stock M, Gettner M, Hagge H, Heinzel K, Kohlus J, Stumpe H (2005) Salzwiesen an der Westküste von Schleswig-Holstein 1998 - 2001, Vol 15. Schriftenreihe des Nationalparks SchleswigHolsteinisches Wattenmeer, Boyens Buchverlag, Heide.

Strieckmann R (1989) Pflanzliche Biomasse- und Nährstoffvorräte in verschiedenen Salzvegetationstypen. Diploma Thesis. Georg-August University Göttingen.

Sullivan G, Callaway JC, Zedler JB (2007) Plant assemblage composition explains and predicts how biodiversity affects salt marsh functioning. Ecological Monographs 77:569-590. doi:10.1890/061947.1.

Tripathee R, Schaefer KVR (2015) Above- and belowground biomass allocation in four dominant salt marsh species of the eastern United States. Wetlands 35:21-30. doi:10.1007/s13157-014-0589-z.

Ungar IA (1998) Are biotic factors significant in influencing the distribution of halophytes in saline habitats? The Botanical Review 64:176-199. doi:10.1007/BF02856582.

Valiela I, Teal JM (1974) Nutrient limitation in salt marsh vegetation. Ecology of halophytes. Academic Press, New York, USA:547-563.

Valiela I, Teal JM, Persson NY (1976) Production and dynamics of experimentally enriched salt marsh vegetation: Belowground biomass. Limnology and Oceanography 21:245-252.

van Eerdt MM (1985) The influence of erosion and accretion in salt marshes of the Oosterschelde, The Netherlands. Vegetatio 62:367-373.

van Wijnen HJ, Bakker JP (1999) Nitrogen and Phosphorus limitation in a coastal barrier salt marsh: the implications for vegetation succession. Journal of Ecology 87:265-272.

Veeneklaas RM, Dijkema KS, Hecker N, Bakker JP (2013) Spatio-temporal dynamics of the invasive plant species Elytrigia atherica on natural salt marshes. Applied Vegetation Science 16:205-216. doi:10.1111/j.1654-109X.2012.01228.x.

Weisser WW, Roscher C, Meyer ST, Ebeling A, Luo G, Allan E, Besser H, Barnard RL, Buchmann N, Buscot F, Engels C, Fischer C, Fischer M, Gessler A, Gleixner G, Halle S, Hildebrandt A, 
Hillebrand H, Kroon H de, Lange M, Leimer S, Le Roux X, Milcu A, Mommer L, Niklaus PA, Oelmann Y, Proulx R, Roy J, Scherber C, Scherer-Lorenzen M, Scheu S, Tscharntke T, Wachendorf M, Wagg C, Weigelt A, Wilcke W, Wirth C, Schulze E-D, Schmid B, Eisenhauer N (2017) Biodiversity effects on ecosystem functioning in a 15-year grassland experiment: Patterns, mechanisms, and open questions. Basic and Applied Ecology 23:1-73. doi:10.1016/j.baae.2017.06.002.

Windham L, Weis JS, Weis P (2003) Uptake and distribution of metals in two dominant salt marsh macrophytes, Spartina alterniflora (cordgrass) and Phragmites australis (common reed). Estuarine, Coastal and Shelf Science 56:63-72. doi:10.1016/S0272-7714(02)00121-X. 


\section{CHAPTER}

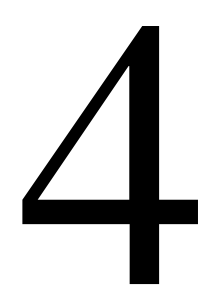

\section{Water sources of plant uptake along a salt marsh flooding gradient}

Regine Redelstein, Heinz Coners, Alexander Knohl, Christoph Leuschner

Published in

Oecologia 2018, Vol. 188, Number 2, pp. 607 - 622

doi:10.1007/s00442-018-4229-9 


\begin{abstract}
Salt marsh plants are affected by regular tidal inundation exposing them to saline water as a potential water source. This study aimed at quantifying the water uptake of plants depending on their distance from the sea and exploring plant responses to changing inundation regimes. We used stable isotope ratios $\left(\delta^{18} \mathrm{O}\right)$ to determine the proportions of seawater and precipitation water used by three salt marsh species (Spartina anglica, Atriplex portulacoides and Elytrigia atherica) from a German North Sea coast salt marsh. Additionally, A. portulacoides was transplanted to experimental islands at three elevation levels to investigate its plasticity in water use in the course of future sea level rise. We found a marked gradient in plant seawater use from the lowermost pioneer zone (79-98\% seawater uptake by $S$. anglica) to the lower marsh (61-95\% by A. portulacoides) and the upper marsh (25$39 \%$ by E. atherica). Seasonal differences in water use were not pronounced, likely due to the absence of longer dry periods during summer in these temperate salt marshes. Contradicting our expectation, roots in deeper soil showed higher water uptake rates per fine root mass than topsoil roots suggesting effective root adaptation to the anoxic subsoil. Transplanted A. portulacoides plants significantly increased the uptake of seawater with increasing inundation indicating flexibility in the use of water sources by this species which may facilitate acclimation to rising sea levels. We conclude that the zonation of salt marsh vegetation reflects the availability of water sources along the inundation gradient.
\end{abstract}

Keywords: Coastal vegetation, Precipitation, Sea level rise, Stable isotopes, Tidal inundation 


\subsection{Introduction}

Salt marshes are ecosystems at the interface of land and sea, which are strongly influenced by tidal inundation. They play an important role in coastal protection, in carbon sequestration, as habitats of a rich fauna, and as traps for nutrients, which are imported from the eutrophicated coastal waters (Barbier et al. 2011; Nelson and Zavaleta 2012; Möller et al. 1999; Mcleod et al. 2011). As these semi-aquatic ecosystems are particularly vulnerable to rising sea levels in the course of climate change, understanding the water sources accessed by salt marsh plants and the plants' flexibility in using different water sources with altered inundation regimes is important for assessing their capacity to withstand sea level rise.

Salt marsh vegetation typically shows a clear zonation with elevation and increasing distance from the sea. These vegetation patterns are likely caused by gradients in abiotic conditions, notably inundation frequency, salinity, soil anoxia, and sulfide, manganese and/or iron toxicity (Armstrong et al. 1985; Ungar 1998; Cooper 1982; Rozema et al. 1985). The characteristic sequence of plant species and communities along this gradient reflects different plant strategies of morphological and physiological adaptation to the multiple stress encountered in the lower and higher marsh (Leuschner and Ellenberg 2017). Plants using seawater as a water source have developed various mechanisms for minimizing the negative effects of high $\mathrm{Na}^{+}$and $\mathrm{Cl}^{-}$concentrations in the cell sap, which may harm metabolism and growth. Adaptation strategies include the excretion of salt ions through glands and bladders, salt exclusion during water uptake by the root, and the dilution of salt ions at the cellular level by increased water uptake resulting in succulence (Rozema et al. 1985; Leuschner and Ellenberg 2017; Munns and Tester 2008). Furthermore, some plants in saline environments increase their salt tolerance by accumulating nitrogen-containing compounds such as proline and quaternary ammonium compounds in the cell sap while accumulating $\mathrm{Na}^{+}$and $\mathrm{Cl}^{-}$in the vacuole (intracellular salt compartmentalization) (Stewart and Lee 1974; Flowers 1985; Munns and Tester 2008). Along the salt marsh elevation gradient, plants of the lower marsh habitats are exposed to seawater more frequently and for longer periods of time than plants of the higher marsh. The former have access to freshwater in the soil from precipitation only during relatively short time frames, namely only when rain is falling during low tide. Thus, plants differ in their access to seawater and precipitation water along the flooding gradient, when absorbing water for transpiration and metabolic processes (Flowers and Colmer 2008).

While there are numerous studies on plant water uptake in mangrove ecosystems, i.e. tropical and subtropical coastal wetlands, there are, to our knowledge, no comparable studies on plant water use in north-west European salt marshes. Studies on the use of different water sources by mangrove trees 
showed that these woody plants show a flexible water use strategy allowing them to utilize saline as well as fresh water depending on water availability. Consequently, the utilization of water sources varies among seasons and habitats (Santini et al. 2015; Ewe et al. 2007; Lin and Sternberg 1993; Wei et al. 2013). A study on subtropical salt marsh plants indicated that plants shift their water sources along a mixing gradient between seawater and meteoric endmembers with increasing use of meteoric water at less inundated sites (Romero and Feakins 2011).

Stable isotopes are a powerful tool for studying the sources of plant water uptake since water sources differ in their isotopic compositions. Precipitation water is depleted in ${ }^{2} \mathrm{H}$ and ${ }^{18} \mathrm{O}$ compared to seawater due to isotopic fractionation during evaporation resulting in more negative signatures in water vapor and precipitation (Sternberg and Swart 1987; Sternberg et al. 1991; Dawson et al. 2002). Therefore, the isotopic composition of xylem water can be used to trace the sources of water taken up by the plant. Romero and Feakins (2011) and Eley et al. (2014) found a trend toward increasing ${ }^{2} \mathrm{H}-$ enrichment in xylem water with increasing inundation time in Californian and English salt marsh plants, indicating variable water sources along the inundation gradient. In the present study with temperate salt marsh species we aimed at quantifying the contribution of marine and atmospheric water sources to plant water uptake by means of stable isotopes, and at identifying the soil depth of maximum water uptake.

A prerequisite for the use of stable isotopes in plant water uptake studies is that there is no isotopic fractionation during water uptake. This means that the isotopic signal of xylem water reflects the signal of the plants' water source (White et al. 1985; Dawson et al. 2002). This premise appears to apply for terrestrial non-halophytic plants (Dawson and Ehleringer 1991; Barnard et al. 2006). However, plants adapted to saline environments often develop highly suberized and lignified cell walls in their roots such as the Casparian strip on endodermal cell walls to control salt influx and prevent water loss to the saline soil (Ellsworth and Williams 2007; Hajibagheri et al. 1985). Water movement along the symplastic pathway potentially fractionates hydrogen isotopes, as was observed for mangroves (Lin and Sternberg 1993; Ladd and Sachs 2015) and woody xerophytes (Ellsworth and Williams 2007). Simultaneous fractionation of oxygen isotopes in water was not observed. This suggests that ${ }^{18} \mathrm{O}$ is a more useful tool for tracing water sources in halophytes than ${ }^{2} \mathrm{H}$.

Since the sea level has been rising by about $1.8 \mathrm{~mm} \mathrm{year}^{-1}$ over the past century in the Wadden Sea region (Oost et al. 2009), we further asked how flexible salt marsh species are in their use of water sources when facing increasing inundation frequencies. Salt marshes are threatened by an accelerated sea level rise as it may potentially lead to the drowning of these semi-terrestrial coastal ecosystems. There is a continuing debate on the viability of salt marshes under rising sea levels and some dispute on the question whether vertical accretion of the marshes is sufficient to sustain elevations with tidal 
flooding regimes that can be tolerated by the plant communities (Greaver and Sternberg 2007; Kirwan et al. 2010; Roman 2017; Reed 1995; Morris et al. 2002). With reference to this discussion we investigated whether Atriplex portulacoides, a dominant species in north-west European lower salt marshes, is able to alter its water uptake strategy under changing sea levels. We manipulated inundation frequencies to investigate the effects of increased flooding and salinity stress on salt marsh communities. For this purpose experimental islands with salt marsh vegetation growing at different elevation levels and thus differing inundation regimes were set up in the Wadden Sea of Germany as part of a larger research project (Balke et al. 2017).

With this combined study in a natural salt marsh and on experimental salt marsh islands we aimed at clarifying whether the availability of fresh water and marine water sources is reflected by the use of water sources by characteristic plant species at different elevations along an inundation frequency gradient. Specifically, we tested the following main hypotheses: (i) there is a gradient in plant water use from the pioneer zone to the upper salt marsh along which the use of seawater decreases with increasing distance from the sea, (ii) the use of seawater and precipitation water changes seasonally in dependence on precipitation patterns with higher seawater uptake in drier (precipitation-poor) months, (iii) the relative importance of water uptake from deeper soil layers decreases due to potential anoxia and the presence of toxic substances in deeper soil, and (iv) typical salt marsh halophytes are flexible in the use of water sources with rising sea levels.

\subsection{Materials and Methods}

Study area and experimental set up

The study was performed on Spiekeroog Island on the German North Sea coast (Lower Saxony, $53^{\circ} 45^{\prime} 44^{\prime \prime N} 7^{\circ} 43^{\prime} 23^{\prime \prime E}$, Fig. S4.1). Study plots were located in a salt marsh and on the tidal flats on the southern leeward coast of the barrier island. The local tidal range is $2.7 \mathrm{~m}$. The salt marsh is characterized by three zones differing in their elevation relative to sea level and thus in inundation frequency, each inhabited by a specific plant community: the dominant species in the pioneer zone, which is inundated by most tides except the lowest neap tides (approx. 500-600 times per year), is Spartina anglica C.E. Hubb.. The subsequent lower salt marsh, which is inundated during spring tides approx. 200 times per year, is the most species-rich community with a high cover of Atriplex portulacoides L., Puccinellia maritima (Huds.) Parl., and about eight other species. The upper salt marsh zone is inundated only during high spring tides and strong storm events (approx. 50 times per year) and consists of monospecific stands of Elytrigia atherica (Link) Kerguélen. The mean annual 
temperature at the study site from 1981 to 2016 was $9.74{ }^{\circ} \mathrm{C}$ and the mean annual precipitation was $751.4 \mathrm{~mm}$ (data from the German Meteorological Service (DWD) for the East Frisian island Norderney, $40 \mathrm{~km}$ away from our sampling location, Fig S4.2, Table S4.1).

In the natural salt marsh, we established six study plots with a size of $2 \mathrm{~m} \times 2 \mathrm{~m}$ in the pioneer zone, the lower and the upper salt marsh, respectively, resulting in 18 plots in total. These natural salt marsh plots will subsequently be termed 'control plots'. In addition, we studied lower salt marsh communities at different height levels and inundation regimes on six experimental islands. Experimental islands (Fig. S4.1) were installed on the tidal mudflats of Spiekeroog Island at approx. $500 \mathrm{~m}$ distance to the natural salt marsh (Balke et al. 2017). Each island consisted of 12 steel cages with an area of $1 \mathrm{~m} \times 1 \mathrm{~m}$ with four replicate cages at a height of $70 \mathrm{~cm}, 100 \mathrm{~cm}$ and $130 \mathrm{~cm}$, respectively. The height levels corresponded to the elevation of the three vegetation zones in the natural salt marsh (pioneer zone, lower salt marsh, upper salt marsh), thus simulating the inundation regimes of the three salt marsh zones. Steel cages were lined with a water permeable geotextile (HaTe ${ }^{\circledR} 1000 \mathrm{~g} / \mathrm{m}^{2}$, Huesker, Germany) and polyethylene bags $(0.14 \mathrm{~mm})$ in the lower sediment profile section in order to prevent complete drainage of the islands. The cages were filled with sediment from the surrounding tidal flat and were planted with sods from the lower salt marsh on top of the sediment on all three height levels. The islands were protected against scouring during inundation by installing steel shields on all sides of the islands. A detailed description of island construction is given by Balke et al. (2017).

\section{Sampling}

Samples for isotope analysis were taken from the natural salt marsh and the experimental islands in September 2014, directly after setup of the islands, and in March and August 2015. We analyzed the $\delta^{2} \mathrm{H}$ and $\delta^{18} \mathrm{O}$ signature of plant and soil material as well as of precipitation water and seawater as possible plant water sources. We chose these two water sources as the two endpoints of the range of expected stable isotope ratios, neglecting further potential water sources such as groundwater or river water. Röper et al. (2012) found that the $\delta^{18} \mathrm{O}$ signature of groundwater varies on Spiekeroog Island within a narrow range (-6.5 to $-7.5 \%$ ), reflecting the isotopic signal of precipitation. Thus, a distinction between the $\delta^{18} \mathrm{O}$ values of precipitation and groundwater would not have been practicable in our study. In any case, the freshwater lense below Spiekeroog Island does not extend to our sampling plots (Röper et al. 2012) which are located in the transition zone between land and sea. Freshwater input from river estuaries on the mainland will play a negligible role as a possible water source, as no estuaries are located in the neighborhood (Röper et al. 2012). 
Precipitation water was collected from rain events occurring in the week prior to the date of plant material sampling. In order to obtain unfractionated precipitation water, we utilized a minimizedevaporation collector as described in Gröning et al. (2012). Monthly precipitation amounts and the sampling dates in relation to precipitation events are given in Fig. S4.2. Seawater was collected on sampling days directly from the ocean surface (Wadden Sea) close to the study plots during high tide. Soil and plant material was sampled from the salt marsh plots and from the transplanted vegetation on the experimental islands (six replicates per salt marsh zone on control plots and experimental islands, respectively). Soil samples were taken with a stainless steel auger $(35 \mathrm{~mm}$ diameter, soil depth 0$30 \mathrm{~cm}$ ). Soil cores were subdivided into segments of six depth layers: 0-3, 3-6, 6-10, 10-15, 15-20, and $20-30 \mathrm{~cm}$. Sub-samples of soil were collected from the centre of the core of each segment. For determination of the stable isotopic composition of plant water, root crowns, i.e. the transition zone between the root and the shoot, from three individuals per plant species and plot were sampled and cleaned from remaining soil particles. For non-woody, herbaceous plants, xylem water of the root crown has been shown to reflect the isotopic signal of the plants' water source best (Barnard et al. 2006). In the control plots, we collected samples of one species per salt marsh zone which occurred with high abundance: Spartina anglica from the pioneer zone, Atriplex portulacoides from the lower salt marsh and Elytrigia atherica from the upper salt marsh. On the experimental islands, we collected samples of Atriplex portulacoides from all three height levels, since sods from the lower salt marsh had been transplanted to all three levels. All samples were collected in gas-tight $12 \mathrm{ml}$ exetainers (Labco Ltd., High Wycombe, UK), stored in a cool box for transportation and kept frozen in the lab until water extraction and analysis.

To relate the proportion of water uptake to the proportion of fine root mass $(<2 \mathrm{~mm}$ in diameter) in a given soil depth, we referred to fine root mass data collected in a previous study (Redelstein et al. 2018). For measuring fine root mass, separate samples were taken with a stainless steel corer (35 mm diameter) on all plots to a depth of $40 \mathrm{~cm}$. Soil cores were divided into depth intervals of $0-10 \mathrm{~cm}, 10$ $20 \mathrm{~cm}$ and $20-40 \mathrm{~cm}$. The soil material was washed over a sieve with $200 \mu \mathrm{m}$ mesh size to separate roots from sediment. Under a binocular, the fine roots were further cleaned and separated from rhizomes and other organic material before determining the dry mass of the fine roots (Redelstein et al. 2018).

\section{Cryogenic vacuum extraction}

Xylem water from root crowns and soil water was extracted by cryogenic water extraction (Ingraham and Shadel 1992; Dalton 1988; Dawson and Ehleringer 1993). The cryogenic extraction line was set 
up according to Orlowski et al. (2013) with modifications proposed by Koeniger et al. (2011). Samples were extracted directly from the gas-tight exetainers connected to the extraction tubes by piercing the septum of the vials with a cannula (diameter $1.2 \mathrm{~mm}$ ). The system was evacuated to approx. $10^{0}-10^{-1}$ mbar by means of a vacuum pump (Rotary vane pump RZ 2.5, vacuubrand, Wertheim, Germany). During the extraction process, samples were heated to $80{ }^{\circ} \mathrm{C}$ by means of a water bath and the evaporated water was trapped in the lower part of V-shaped glass tubes submerged in liquid nitrogen. In order to guarantee complete water extraction and to obtain unfractionated water samples, extraction time was chosen based on preliminary tests with soil samples from our study sites, which showed maximal extraction efficiency at an extraction time of $2 \mathrm{~h}$. Thus, samples were extracted for $2 \mathrm{~h}$. The mean extraction efficiency of all samples was $99.25 \%$ indicating an almost complete extraction of samples for the given extraction conditions (temperature, vacuum, time). Samples with an extraction efficiency of less than $95 \%$ were removed from data analysis; this applied to $1.2 \%$ of all samples. A minimum of 4 replicate samples was available for all plots and sampling sessions. Extracted water was pipetted to $2 \mathrm{ml}$ glass vials and stored at $4{ }^{\circ} \mathrm{C}$ until stable isotope analysis.

\section{Stable isotope analysis}

Stable isotope measurements were conducted by Cavity Ring-Down Spectroscopy (CRDS) with a Picarro L2120-i $\delta \mathrm{D} / \delta^{18} \mathrm{O}$ Isotopic Water Analyzer (Picarro Inc., Santa Clara, California, USA) coupled to an A0211 high-precision vaporizer. Due to the measurement of samples extracted from soil and roots, and potential contamination with volatile organic substances possibly causing spectral interference, a microcombustion module (MCM) was inserted between the vaporizer and the analyzer of the instrument (Martin-Gomez et al. 2015). Samples were injected by a PAL-autosampler (CTC Analytics AG, Zwingen, Switzerland) and each sample was measured 10 times at high precision mode. The first three measurements per sample were discarded. Prior to the analysis of our samples, a reliability test of the micro-combustion module was carried out by measuring a set of samples in parallel by isotope ratio mass spectroscopy (IRMS) and CRDS. Values measured by CRDS correlated significantly with those measured by IRMS with $\delta^{18} \mathrm{O}_{\mathrm{CRDS}}=0.96 \cdot \delta^{18} \mathrm{O}_{\text {IRMS }}-0.53\left(\mathrm{r}^{2}=0.996\right)$ and $\delta^{2} \mathrm{H}_{\mathrm{CRDS}}=0.996 \cdot \delta^{2} \mathrm{H}_{\text {IRMS }}-0.63\left(\mathrm{r}^{2}=0.998\right)$. There was no significant effect of the type of water measured (pure water sample or samples extracted from organic material) on the difference between IRMS and CRDS measurements ( $p>0.05)$ (Fig. S4.3, Table S4.2).

Isotopic ratios are expressed relative to the international standard Vienna Standard Mean Ocean Water (VSMOW) in per mil (\%) according to equation 4.1: 
$\delta^{18} \mathrm{O}$ or $\delta{ }^{2} \mathrm{H}=\left(\frac{\mathrm{R}_{\text {Sample }}}{\mathrm{R}_{\text {Standard }}}-1\right)$

\section{Equation 4.1}

where $\mathrm{R}$ is the ${ }^{18} \mathrm{O} /{ }^{16} \mathrm{O}$ or ${ }^{2} \mathrm{H} /{ }^{1} \mathrm{H}$ ratio of the sample or the standard, respectively.

Data were checked for remaining potential organic contamination of samples by the ChemCorrect ${ }^{\mathrm{TM}}$ software (Picarro Inc.). This software marked several analyzed samples as possibly contaminated and a few as highly contaminated in the $\mathrm{C}_{2+}$-alcohols, so that a spectral contamination post-processing correction of $\delta^{2} \mathrm{H}$ and $\delta^{18} \mathrm{O}$ values was applied to the raw output as given in Martin-Gomez et al. (2015).

For calibrating the measured values, two internal laboratory standards were used, which covered the full range of values detected in the samples. These were calibrated directly against the international standards VSMOW and SLAP2 (Standard Light Antarctic Precipitation 2) provided by the International Atomic Energy Agency (IAEA) and were analyzed always after 9 samples had been measured to fit a linear regression for calibration. The long-term precision of our laboratory's quality control standard was $\pm 1.30 \%$ and $\pm 0.16 \%$ for $\delta^{2} \mathrm{H}$ and $\delta^{18} \mathrm{O}$, respectively.

\section{Data analysis}

All statistical analyses and graphics were done with R 3.3.2 software (R Development Core Team 2016). The Local Water Line (LWL) was calculated by linear regression of the $\delta^{18} \mathrm{O}$ and $\delta^{2} \mathrm{H}$ values of sea, precipitation and soil water; the Plant Water Line (PWL) was calculated by linear regression of the $\delta^{18} \mathrm{O}$ and $\delta^{2} \mathrm{H}$ values of water extracted from roots using Model II linear regressions (ranged major axis, RMA). It has been shown that there is significant hydrogen isotopic fractionation during water uptake in coastal wetland plants, whereas oxygen isotope ratios of plant water match those of the source water (Lin and Sternberg 1993). Therefore, we only considered $\delta^{18} \mathrm{O}$ values for the quantification of plant water sources. For calculation of the fractions of sea and precipitation water contributing to plant water, we calculated a two-source mixing-model (Dawson et al. 2002) according to equation 4.2 .

$\mathrm{f}_{\text {sea }}=\frac{\delta_{\text {plant }}-\delta_{\text {precipitation }}}{\delta_{\text {sea }}-\delta_{\text {precipitation }}}$

\section{Equation 4.2}

with $\mathrm{f}_{\text {sea }}$ being the fraction of seawater contributing to plant water and $\delta_{\text {plant/sea/precipitation }}$ being the $\delta^{18} \mathrm{O}$ values of plant, sea and precipitation water, respectively. The fraction of precipitation contributing to plant water was calculated as $\mathrm{f}_{\text {precipitation }}=1-\mathrm{f}_{\text {sea }}$. 
The contribution of different soil depths to plant water use in cases where more soil depths (water sources) than isotopes are present (i.e. where no clear solution exists) was determined by a Bayesian stable isotope mixing model based on Gaussian likelihood (Parnell et al. 2010) using the R-package 'simmr'. In order to reduce the uncertainty for the contribution of each single soil layer due to the inclusion of a larger number of water sources but only one isotope species, we combined the six sampled soil layers to three layers: top $=0-10 \mathrm{~cm}$ soil depth, $\mathrm{mid}=10-20 \mathrm{~cm}$ soil depth, deep $=20$ $30 \mathrm{~cm}$ soil depth. Differences in $\delta^{18} \mathrm{O}$ values among water sources were determined using a twofactorial (water source, season) analysis of variance (ANOVA). Differences in $\delta^{18} \mathrm{O}$ values among plant water and in the proportion of seawater used by the plant were tested using a three-factorial (season, salt marsh zone, treatment (i.e. control plot/ experimental island)) ANOVA. Significant factors were subsequently identified using Tukey's honestly significance difference as a post-hoc test. A linear regression was calculated in order to examine the relation between the contribution of water and the proportion of fine root mass in a soil layer using data on fine root mass collected in a previous study. Tests of statistical significance were based on a 0.05 significance level.

We calculated the ${ }^{2} \mathrm{H}$-discrimination, which occurs during plant water uptake, under the assumption that no fractionation of oxygen isotopes takes place during plant water uptake and that the $\delta^{2} \mathrm{H} / \delta^{18} \mathrm{O}$ ratio does not vary among soil depths. The theoretical $\delta^{2} \mathrm{H}$ value in plant water assuming no fractionation $\left(\delta^{2} \mathrm{H}_{\text {plant calc }}\right)$ was calculated from the measured values in plant and soil as

$\delta^{2} \mathrm{H}_{\text {plant calc }}=\frac{\delta^{2} \mathrm{H}_{\text {soil meas }}}{\delta^{18} \mathrm{O}_{\text {soil meas }}} \cdot \delta^{18} \mathrm{O}_{\text {plant meas }}$

Equation 4.3

The fractionation was calculated as the difference between the calculated and the measured $\delta^{2} \mathrm{H}$ value in plant water (equation 4.4).

$\Delta \delta^{2} \mathrm{H}=\delta^{2} \mathrm{H}_{\text {plant calc }}-\delta^{2} \mathrm{H}_{\text {plant meas }}$

\section{Equation 4.4}

\subsection{Results}

\section{Local water line}

There was a strong linear relationship between $\delta^{18} \mathrm{O}$ and $\delta^{2} \mathrm{H}$ in the water sources (LWL: $\delta^{2} \mathrm{H}=6.46$. $\left.\delta^{18} \mathrm{O}-1.06, \mathrm{r}^{2}=0.98, p<0.001\right)$ and water extracted from plant roots (PWL: $\delta^{2} \mathrm{H}=6.21 \cdot \delta^{18} \mathrm{O}-$ 4.75, $\mathrm{r}^{2}=0.97, p<0.001$ ) (Fig. 4.1). The slope and intercept of both LWL and PWL were smaller 
than the values that define the global meteoric water line (GMWL: $\delta^{2} \mathrm{H}=8 \cdot \delta^{18} \mathrm{O}+10$ (Craig 1961)). Precipitation water was depleted in ${ }^{18} \mathrm{O}$ and ${ }^{2} \mathrm{H}$ compared to seawater, whereas the isotopic signatures of water extracted from soil and plants ranged between the signatures of precipitation and seawater endmembers. Plant water was isotopically depleted in ${ }^{2} \mathrm{H}$ in comparison to ${ }^{18} \mathrm{O}$ as indicated by a lower intercept of the PWL.

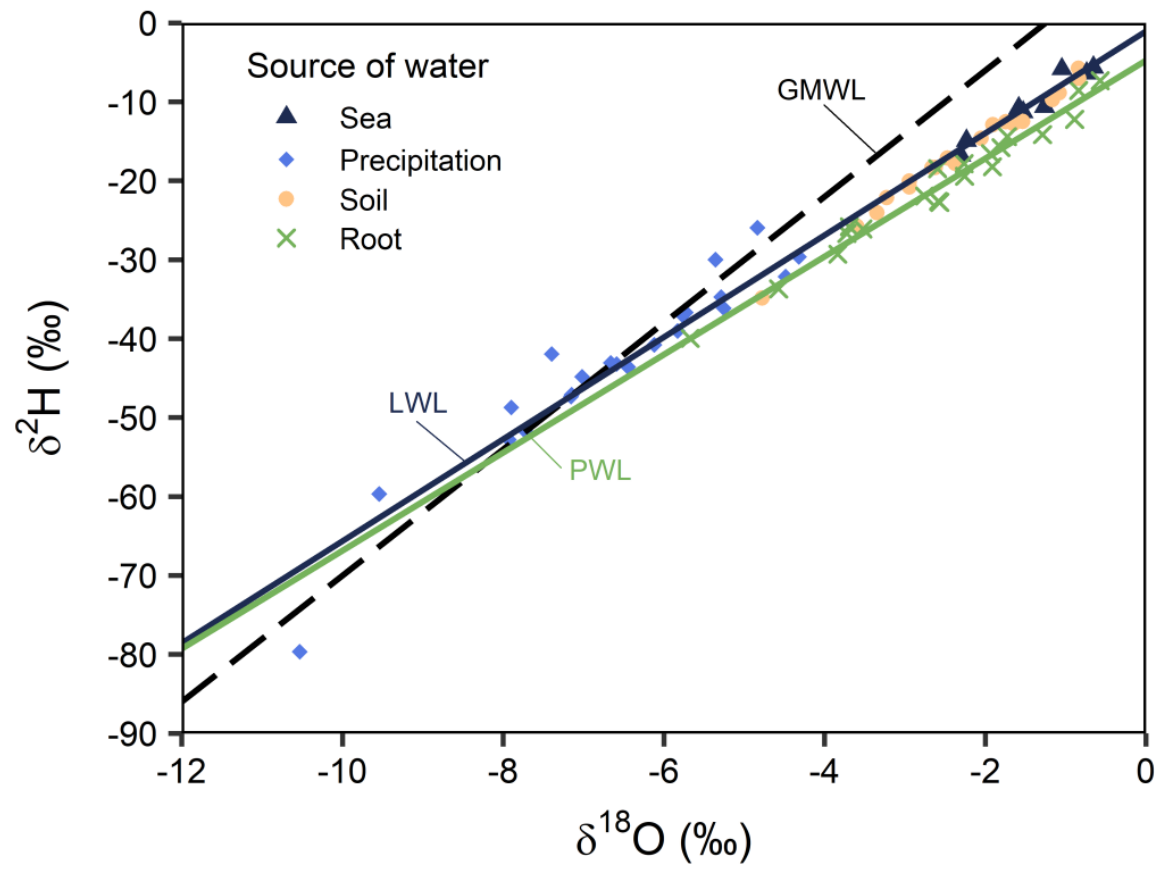

Figure 4.1: $\delta^{2} \mathrm{H}$ versus $\delta^{18} \mathrm{O}$ signatures of different plant water sources (seawater, precipitation water, soil water) and plant water sampled at Spiekeroog Island. In addition to the local water line (LWL) and plant water line (PWL), the global meteoric water line (GMWL; Craig 1961) is shown (dashed line).

\section{$\delta^{18} \mathrm{O}$ values of plant and source water}

The $\delta^{18} \mathrm{O}$ signature differed significantly $(p<0.001)$ between sea and precipitation water in all three sampling campaigns $\left(\mathrm{F}_{1,14}=89.86\right)$. Precipitation water ranged from -8.2 in March to $-5.0 \%$ in August and seawater values varied between -1.8 in March and $-0.9 \%$ in August (Fig. 4.2). These differences in isotopic composition allowed for further calculations to distinguish between the two sources of water used by the salt marsh plants. $\delta^{18} \mathrm{O}$ values of sea and precipitation water were less negative in the late summer months than during the early spring sampling $\left(\mathrm{F}_{1,14}=4.61, p<0.05\right)$. 
a) Control plots, September 2014

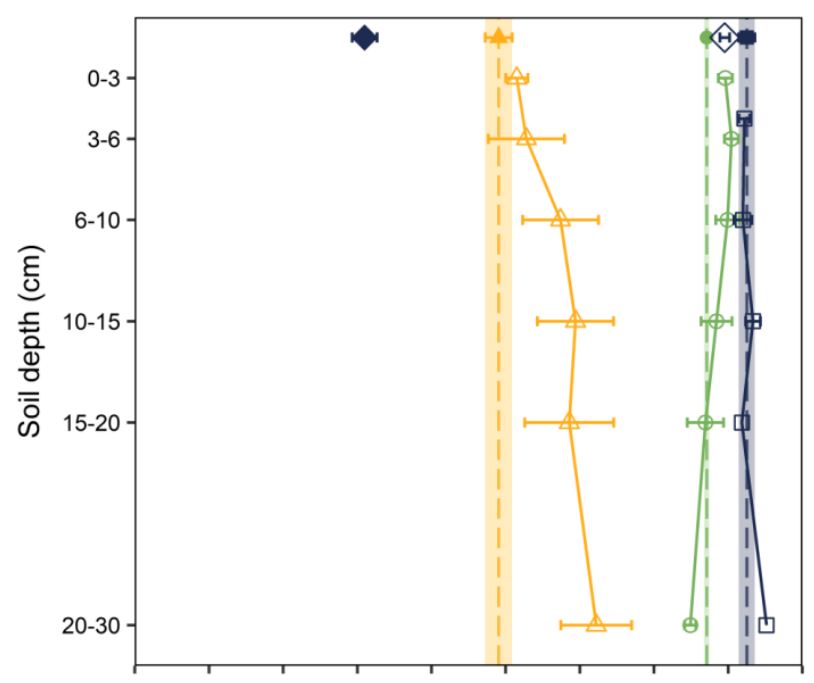

b) Control plots, March 2015

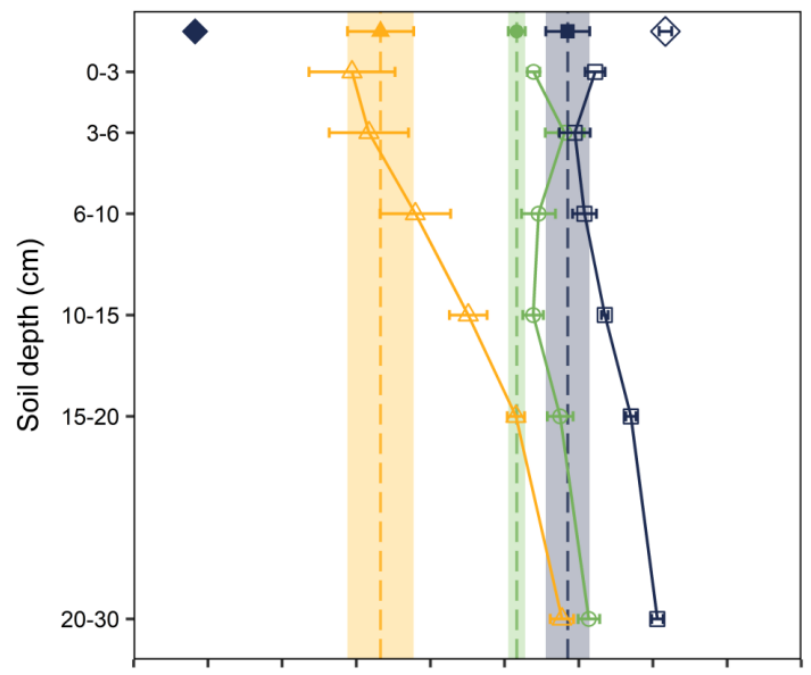

d) Control plots, August 2015

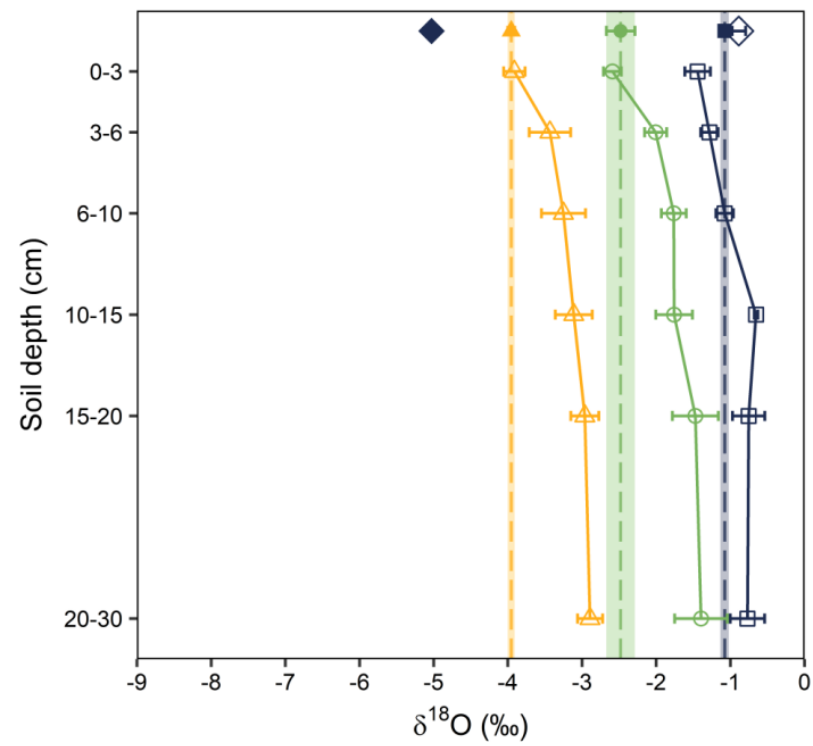

Saltmarsh zone

$\rightarrow$ - Pio

$\rightarrow$ Low

$\simeq$ Upp

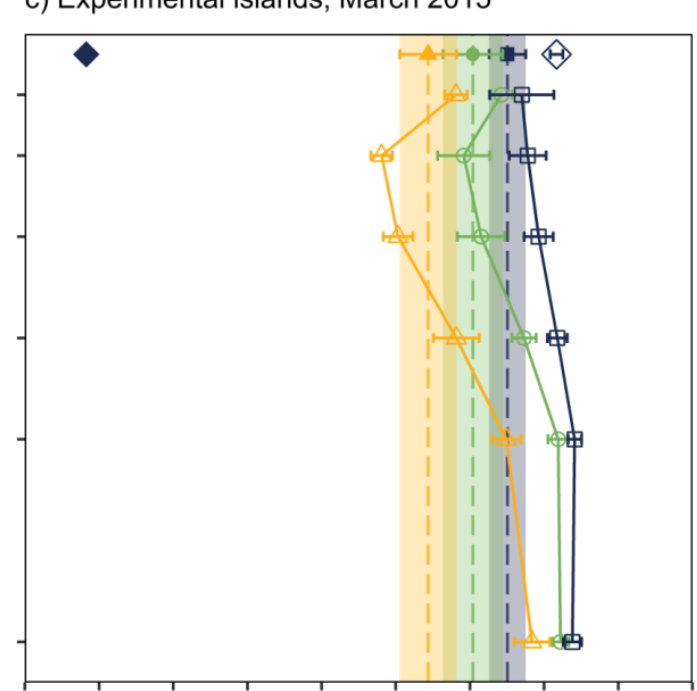

e) Experimental islands, August 2015

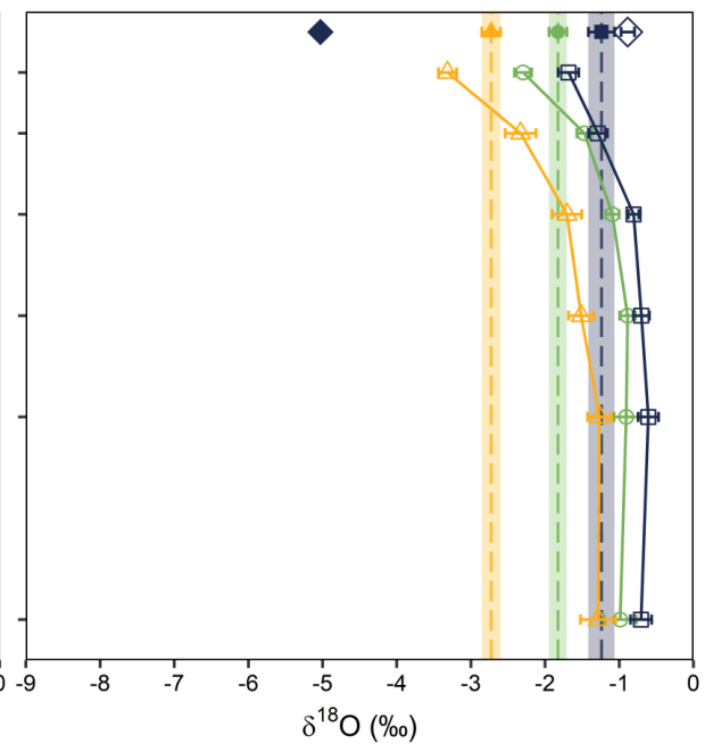


Figure 4.2a)-e): $\delta^{18} \mathrm{O}$ values of soil water (open symbols) depending on soil depth (means \pm se, $\mathrm{n}=6$ ) extracted from the soil in the three salt marsh zones (upper salt marsh (Upp), lower salt marsh (Low), pioneer zone (Pio)) on Spiekeroog Island (control plots) and on the experimental islands. Closed symbols and the dashed vertical lines represent plant water $\delta^{18} \mathrm{O}$ (mean) with shaded areas as standard error (plant species: Upp: Elytrigia atherica, Low: Atriplex portulacoides, Pio: Spartina anglica, Experimental islands: Atriplex portulacoides in all three zones). Filled diamonds represent the $\delta^{18} \mathrm{O}$ signature of precipitation water and open diamonds the $\delta^{18} \mathrm{O}$ signature of seawater sampled on the days before soil and plant material sampling.

The $\delta^{18} \mathrm{O}$ signature of root water extracted from salt marsh plants was significantly affected by all three parameters under investigation ( $p<0.001$; Table 4.1): sampling season (spring, late summer), salt marsh zone (pioneer zone, lower and upper salt marsh), and treatment (control plots, experimental islands). Two-way interaction effects between salt marsh zone:treatment $(p<0.001)$ and season:treatment $(p<0.05)$ were significant, whereas the three-way interaction was not (Table 4.1).

There was a clear gradient in $\delta^{18} \mathrm{O}$ values of plant water across the salt marsh zones with less negative values (closer to seawater) in the pioneer zone and more negative values (closer to precipitation water) in the upper salt marsh (Fig. 4.2). This difference was significant in the control plots among all three zones in late summer, whereas in spring, differences between pioneer zone and lower salt marsh plant water were not significant. Plant water was significantly enriched in heavy isotopes in late summer compared to spring in all three salt marsh zones. On the experimental islands, the gradient in $\delta^{18} \mathrm{O}$ values across the zones was not as pronounced; significant differences were found only between the pioneer zone and the upper salt marsh in late summer. For $\delta^{18} \mathrm{O}$ values of soil water, there was a vertical gradient with more negative values in the upper soil layer and an enrichment with heavy isotopes with increasing soil depth in most cases (Fig. 4.2).

Table 4.1: Results of a three-factorial ANOVA with the effects of salt marsh zone, sampling season and treatment (control plot vs. experimental island) on $\delta^{18} \mathrm{O}$ values of water extracted from roots of saltmarsh plants.

\begin{tabular}{lllll}
\hline source of variation & SS (type II) & df & F value & $\boldsymbol{p}$ value \\
\hline salt marsh zone & 64.47 & 2 & 88.82 & $<2.2 \cdot 10^{-16 * * *}$ \\
season & 46.77 & 1 & 128.85 & $<2.2 \cdot 10^{-16 * * *}$ \\
treatment & 9.97 & 1 & 27.47 & $1.6 \cdot 10^{-6} * * *$ \\
salt marsh zone:season & 0.83 & 2 & 1.14 & 0.3 \\
salt marsh zone:treatment & 8.55 & 2 & 11.78 & $3.9 \cdot 10^{-5 * * *}$ \\
season:treatment & 3.58 & 1 & 9.87 & $0.2 \cdot 10^{-2} *$ \\
salt marsh zone:season:treatment & 0.05 & 2 & 0.06 & 0.9 \\
residuals & 25.41 & 70 & & \\
\hline
\end{tabular}




\section{Contribution of sea and precipitation water to plant water}

We found a clear gradient in the contribution of sea and precipitation water to plant water: the use of seawater by plants decreased with increasing distance from the sea or increasing elevation (Fig. 4.3).

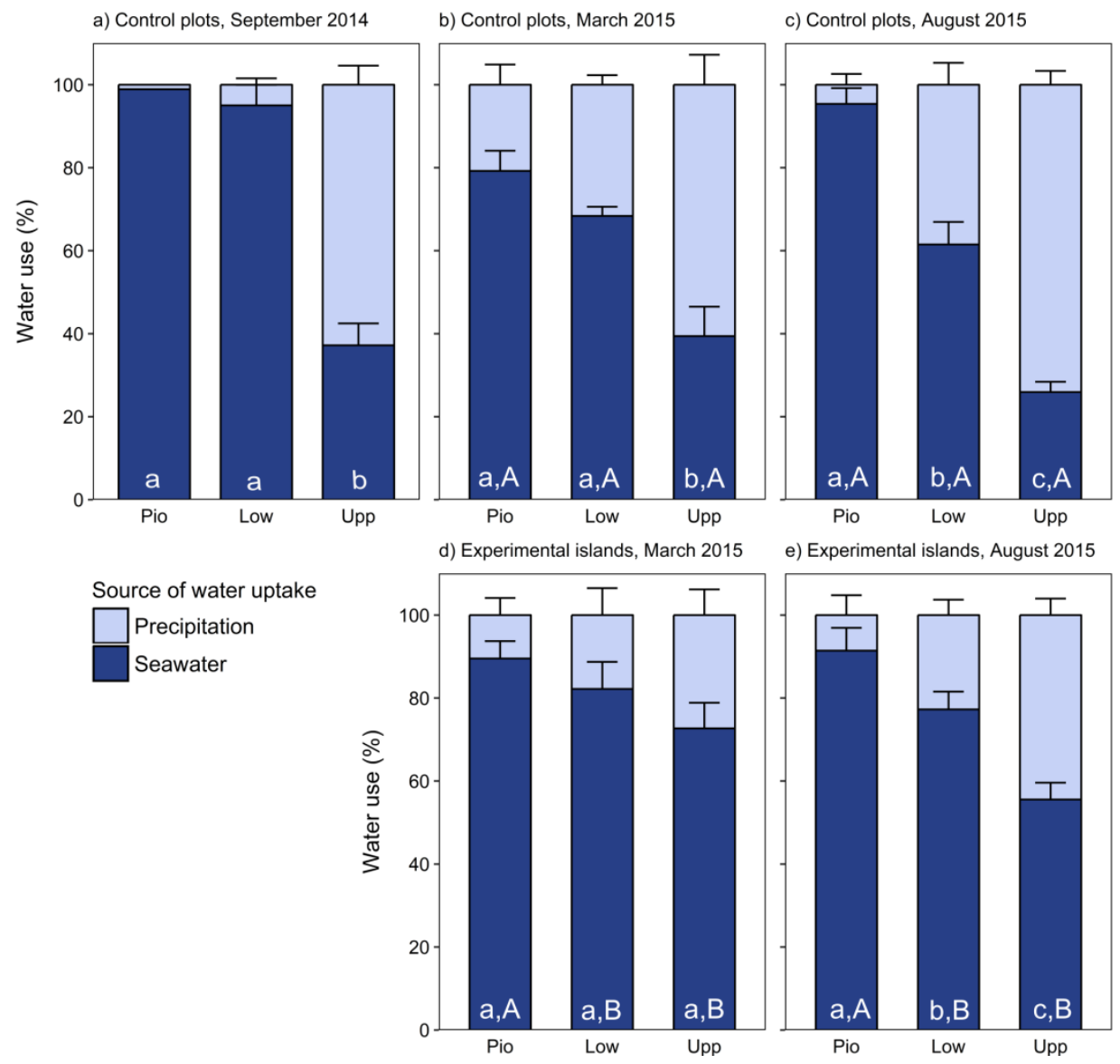

Figure 4.3a)-e): Contribution of precipitation and seawater to plant water in the three salt marsh zones (upper salt marsh (Upp), lower salt marsh (Low), pioneer zone (Pio)) on Spiekeroog Island (Control plots) and on the experimental islands (plant species: Upp: Elytrigia atherica, Low: Atriplex portulacoides, Pio: Spartina anglica, Experimental islands: Atriplex portulacoides in all three zones) at three sampling dates. Presented are means \pm se $(n=6)$. Different small letters indicate statistically significant differences among salt marsh zones on a sampling date and within a treatment, capital letters indicate differences between control plots and experimental islands within salt marsh zones (Tukey HSD tests, $p<0.05$ ).

This was consistent over all sampling dates and for both the control plots and experimental islands. Spartina anglica from the pioneer zone control plots utilized up to $98.9 \%$ seawater, while the proportion of seawater taken up by Elytrigia atherica from the upper salt marsh was only between 25 and $39 \%$. In the late summer months (September and August), the difference among zones was more distinct with a greater proportion of saltwater use by S. anglica and greater proportion of precipitation 
water use by E. atherica compared to the early spring sampling campaign on the control plots. On the experimental islands, where Atriplex portulacoides was sampled from all three height levels, this species utilized different proportions of seawater depending on elevation: as in the natural salt marsh, the use of seawater decreased with increasing height (i.e. less frequent inundation). This difference among height levels was significant in the late summer sampling campaign $(p<0.05)$ but not in March. In August, A. portulacoides utilized more seawater on the lower levels and less seawater on the upper levels compared to March. In general, we observed an increased use of seawater on the experimental islands in all heights compared to the corresponding elevation in the natural salt marsh (significant for the lower and upper salt marsh levels, $p<0.05$ ). Effects of salt marsh zone and treatment (control plots vs. experimental islands) $(p<0.001)$ as well as the two-way interactions salt marsh zone:season $(p<0.01)$, salt marsh zone:treatment $(p<0.001)$ and season:treatment $(p<0.05)$ were statistically significant (Table 4.2).

Table 4.2: Results of a three-factorial ANOVA with the effects of salt marsh zone, sampling season and treatment (control plot vs. experimental islands) on the source of water uptake of salt marsh plants.

\begin{tabular}{lllll}
\hline source of variation & SS (Type II) & df & F value & $\boldsymbol{p}$ value \\
\hline salt marsh zone & 22220.5 & 2 & 76.24 & $<2.2 \cdot 10^{-16 * * *}$ \\
season & 12.6 & 1 & 0.09 & 0.8 \\
treatment & 3165.5 & 1 & 21.72 & $1.6 \cdot 10^{-5 * * *}$ \\
salt marsh zone:season & 1691.3 & 2 & 5.80 & $0.5 \cdot 10^{-2} * *$ \\
salt marsh zone:treatment & 2647.3 & 2 & 9.08 & $0.3 \cdot 10^{-3} * * *$ \\
season:treatment & 628.5 & 1 & 4.31 & $0.4 \cdot 10^{-1} *$ \\
salt marsh zone:season:treatment & 51.4 & 2 & 0.18 & 0.8 \\
residuals & 9472.2 & 65 & & \\
\hline
\end{tabular}

\section{Soil depth of plant water uptake}

According to the Bayesian calibrated mixing model, the topsoil layer $(0-10 \mathrm{~cm})$ contributed most to plant water uptake (Fig. 4.4, Table 4.3). This was true for all salt marsh zones, sampling campaigns as well as on the control plots and the experimental islands. Approximately $50 \%$ of the water taken up by the plants was derived from this soil layer, while the contribution of the intermediate $(10-20 \mathrm{~cm})$ and deep $(20-30 \mathrm{~cm})$ soil layers to plant water was smaller with probabilities between $13-35 \%$ and 12-24\%, respectively. An exception was the September 2014 sampling campaign, where water uptake was rather equally distributed across the soil profile in the pioneer zone and the upper salt marsh, and water uptake in the lower salt marsh was greatest from the deep soil layer (48\%). 


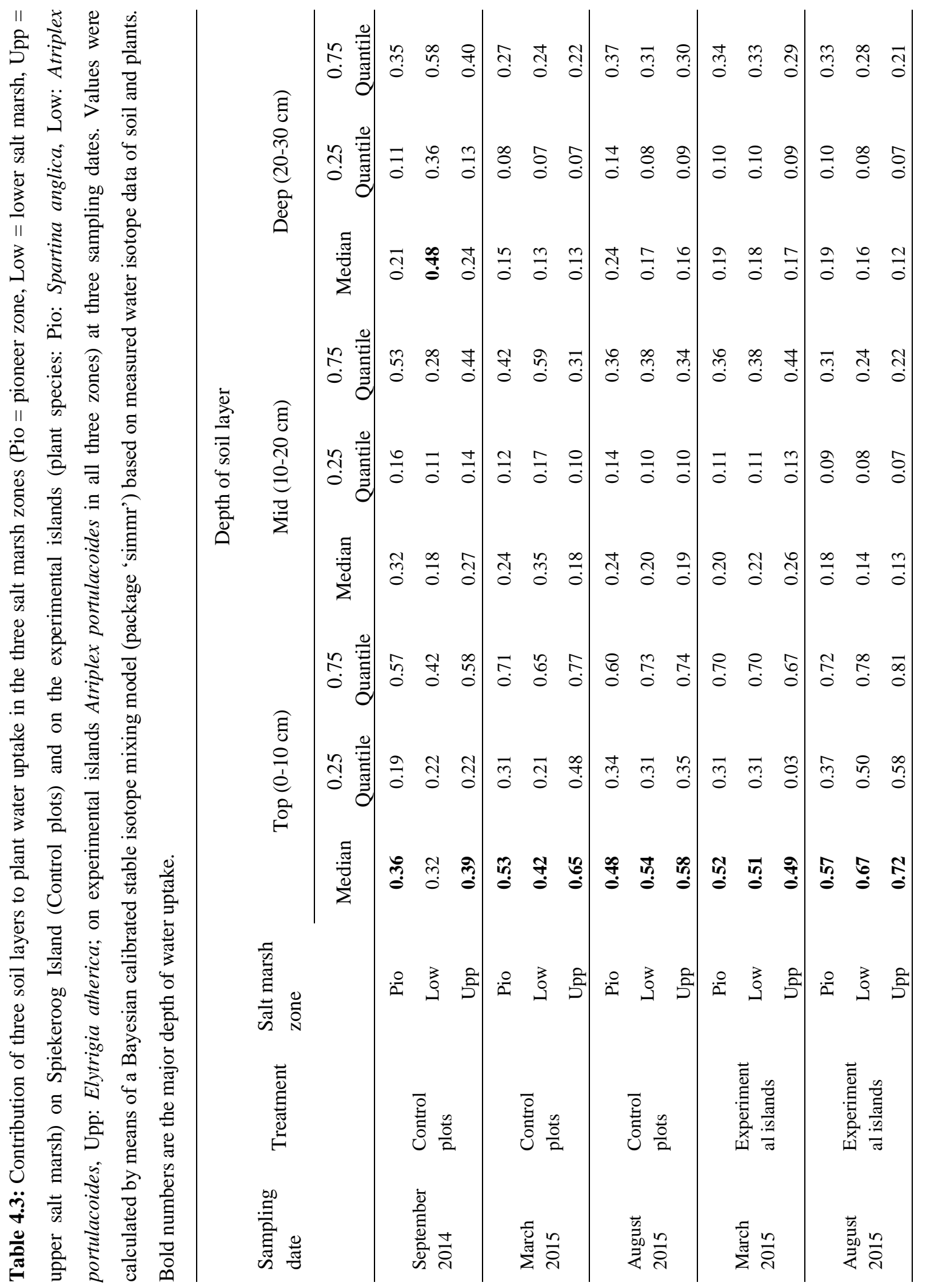


a) Control plots, September 2014
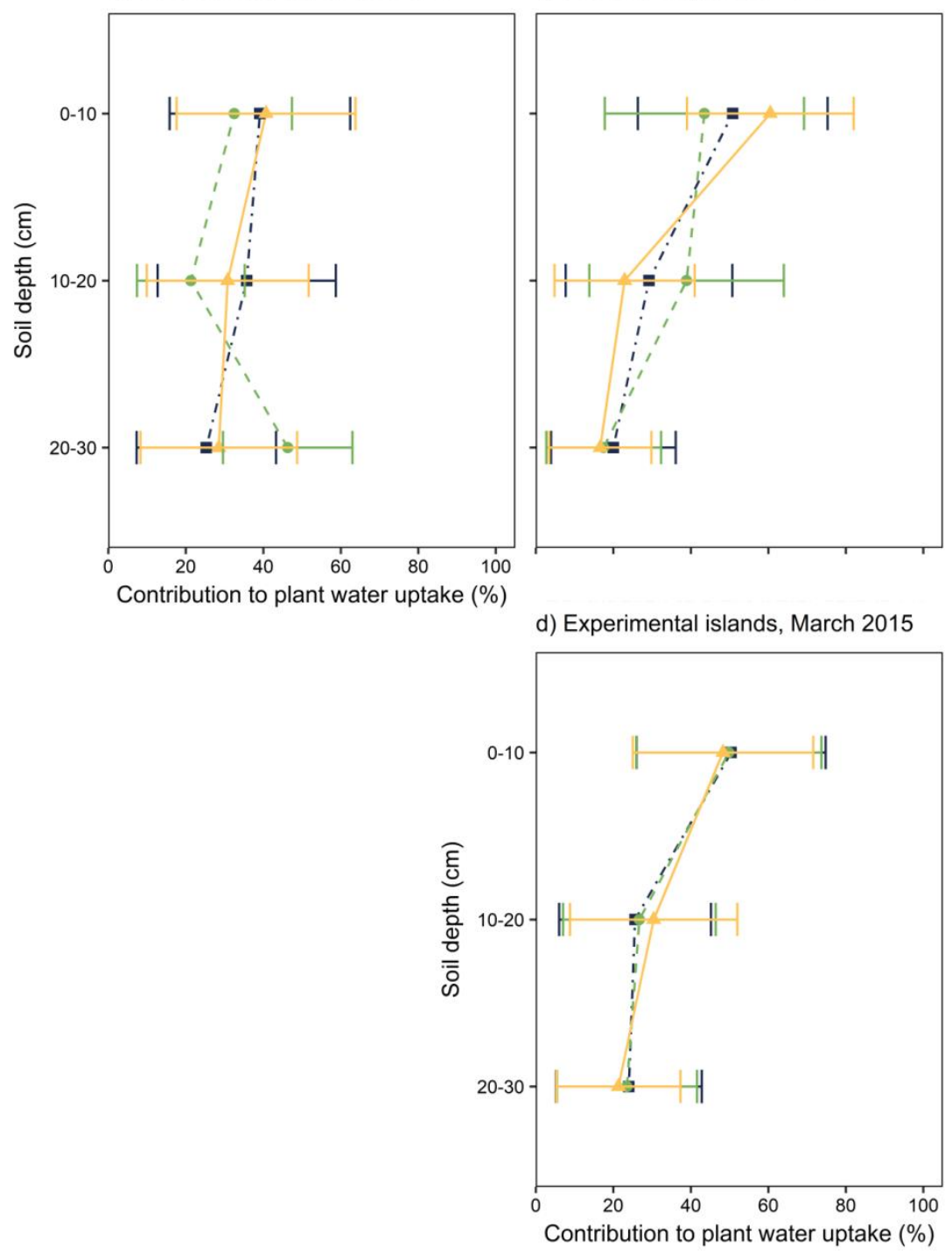

d) Experimental islands, March 2015

b) Control plots, March 2015

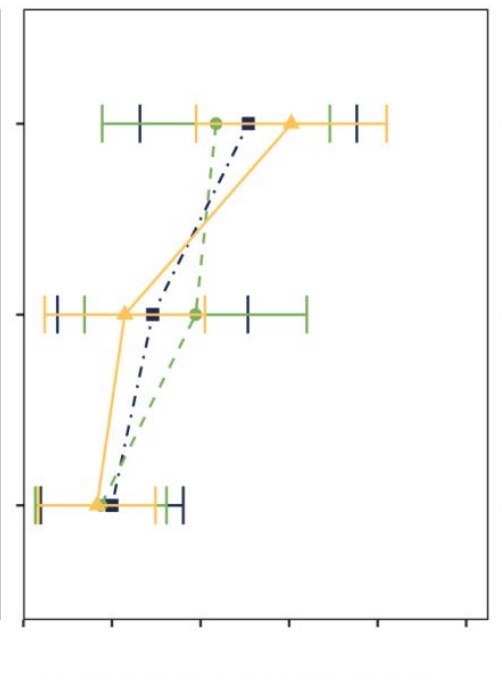

e) Experimental islands, August 2015

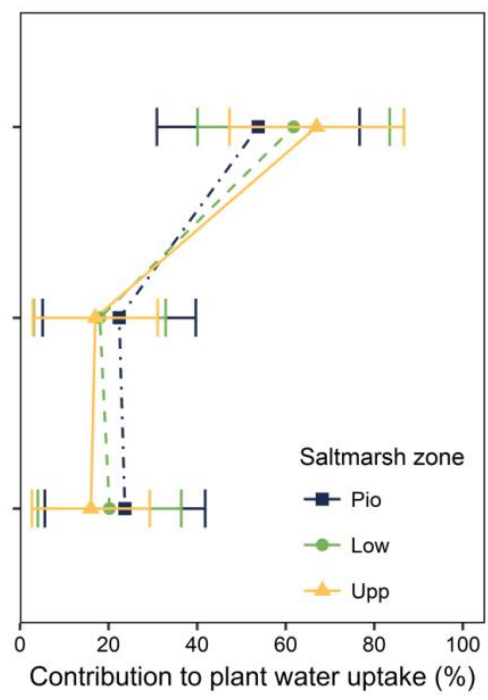

c) Control plots, August 2015

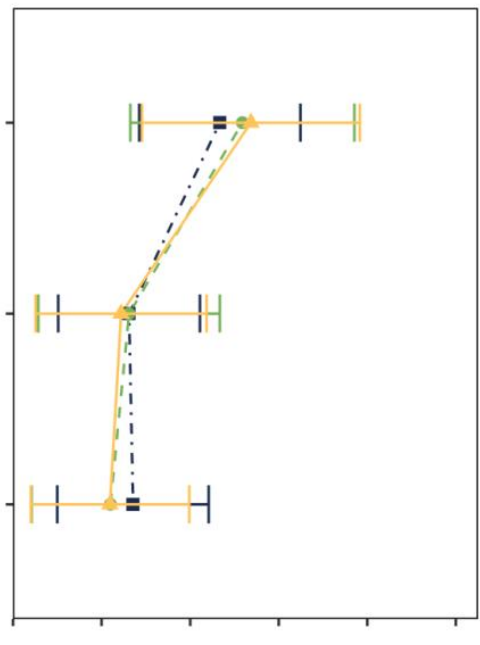

Figure 4.4a)-e): Contribution of soil layers to plant water uptake in the three salt marsh zones (upper salt marsh (Upp), solid line, lower salt marsh (Low), dashed line, pioneer zone (Pio), dot-dashed line) on Spiekeroog Island (Control plots) and on the experimental islands at three sampling dates (plant species: Upp: Elytrigia atherica, Low: Atriplex portulacoides, Pio: Spartina anglica; on experimental islands Atriplex portulacoides in all three zones). Values were calculated by means of a Bayesian calibrated stable isotope mixing model (package 'simmr') based on measured water isotope data of soil and plants. Given are means $\pm s d(n=6)$.

We found a significant positive correlation $(p<0.001)$ between the contribution of water taken up by the plants and the proportion of fine roots present in the respective soil layer (Fig. 4.5a). Accordingly, the topsoil with higher fine root mass density contributed in general more to plant water uptake than the deeper soil layers with smaller fine root mass density. However, the relative water uptake per 
standing fine root mass (i.e. the proportion of water uptake per proportion of fine root mass in a soil layer) was greatest in $20-30 \mathrm{~cm}$ depth, while the water uptake/root mass ratio was smallest in 10 $20 \mathrm{~cm}$ depth (Fig. 4.5b).
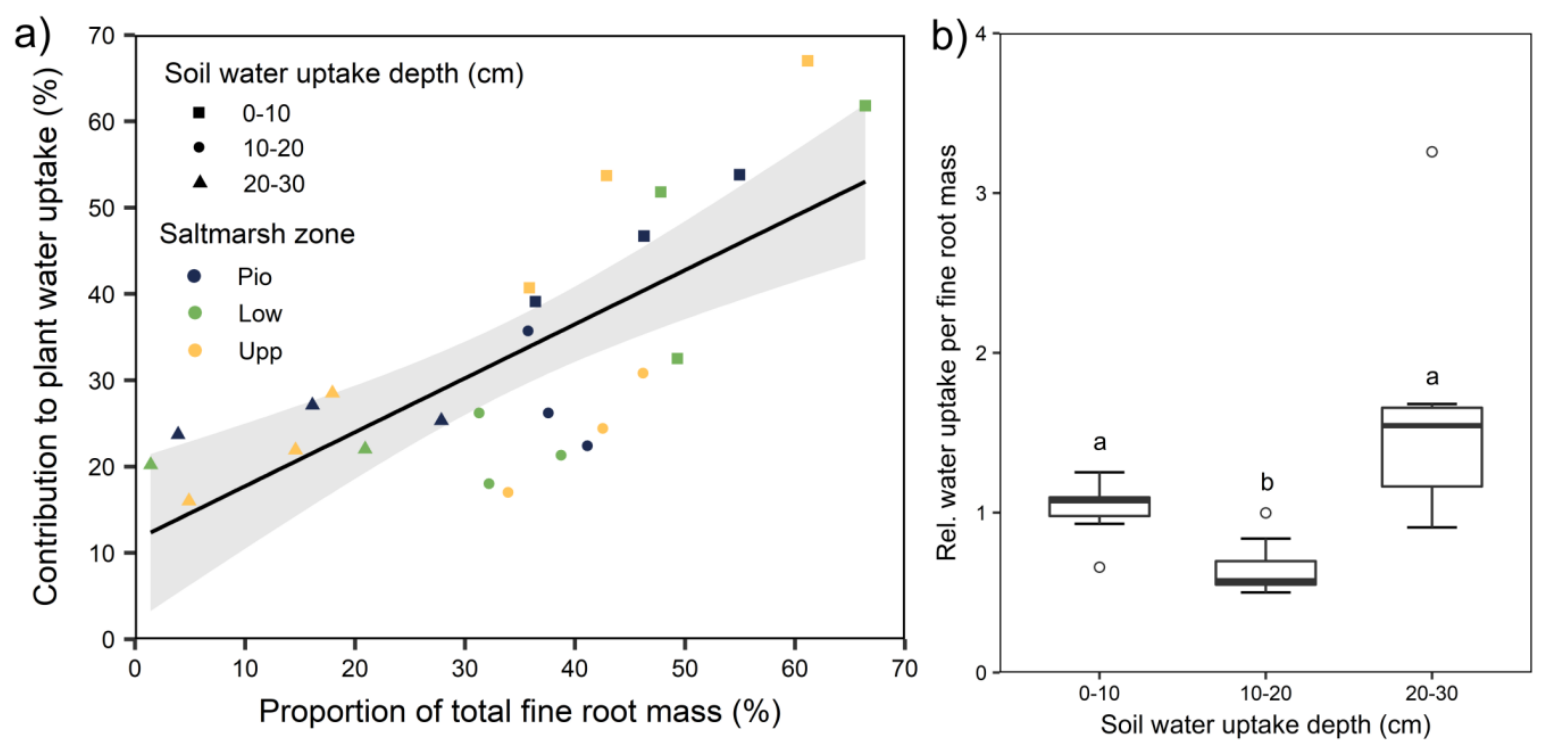

Figure 4.5: a) Linear regression model showing the correlation between the contribution of a specific soil depth to plant water uptake and the proportion of total fine root mass in that soil depth in the salt marsh of Spiekeroog Island and on the experimental islands $(\mathrm{y}=0.63 \mathrm{x}+11.47, p<0.001)$. Values from different salt marsh zones are presented in different colors, values from different soil depths by different symbols. The grey area indicates the $95 \%$ confidence interval. b) Relative water uptake per fine root mass in the different soil layers. Different letters indicate statistically significant differences (Kruskal-Wallis multiple comparisons, $p<0.05$ ).

\subsection{Discussion}

The local water line (LWL) and the plant water line (PWL) as derived from our data deviated from the global meteoric water line with lower slopes and intercepts. The same has also been found by Ewe et al. (2007) and Wei et al. (2013) for surface and soil water in mangrove ecosystems in the Everglades (Florida, US) and the Brisbane region (Australia), respectively, reflecting the evaporation of source waters. Compared to these studies from subtropical climates with higher evaporation rates, the reduction in slope relative to the GMWL was not as strong in our data, since our study took place in a temperate climate. The lower intercept of the PWL compared to the LWL indicates that there is a discrimination of ${ }^{2} \mathrm{H}$ isotopes during plant water uptake by salt marsh plants leading to a depletion of ${ }^{2} \mathrm{H}$ in root water. A similar effect was also reported for other halophytes (Ellsworth and Williams 2007; Lin and Sternberg 1993). Measured $\delta^{2} \mathrm{H}$ signatures of plant water in our study were in nearly all 
cases more negative than values calculated assuming the absence of $\mathrm{H}$ isotope fractionation (Fig. 4.6; significant difference only in two cases), which confirms the depletion of ${ }^{2} \mathrm{H}$ in plant water. Although we detected the highest $\Delta \delta^{2} \mathrm{H}$ also in A. portulacoides (4.33\%o), Eley et al.(2014) reported a much greater $\mathrm{H}$-fractionation for this species $\left(\Delta \delta^{2} \mathrm{H}=28 \%\right.$ ) and other halophyte species in an English salt marsh. Since our data suggest a relatively small ${ }^{2} \mathrm{H}$ discrimination in temperate salt marsh plants, greenhouse experiments are recommended to clarify these findings.
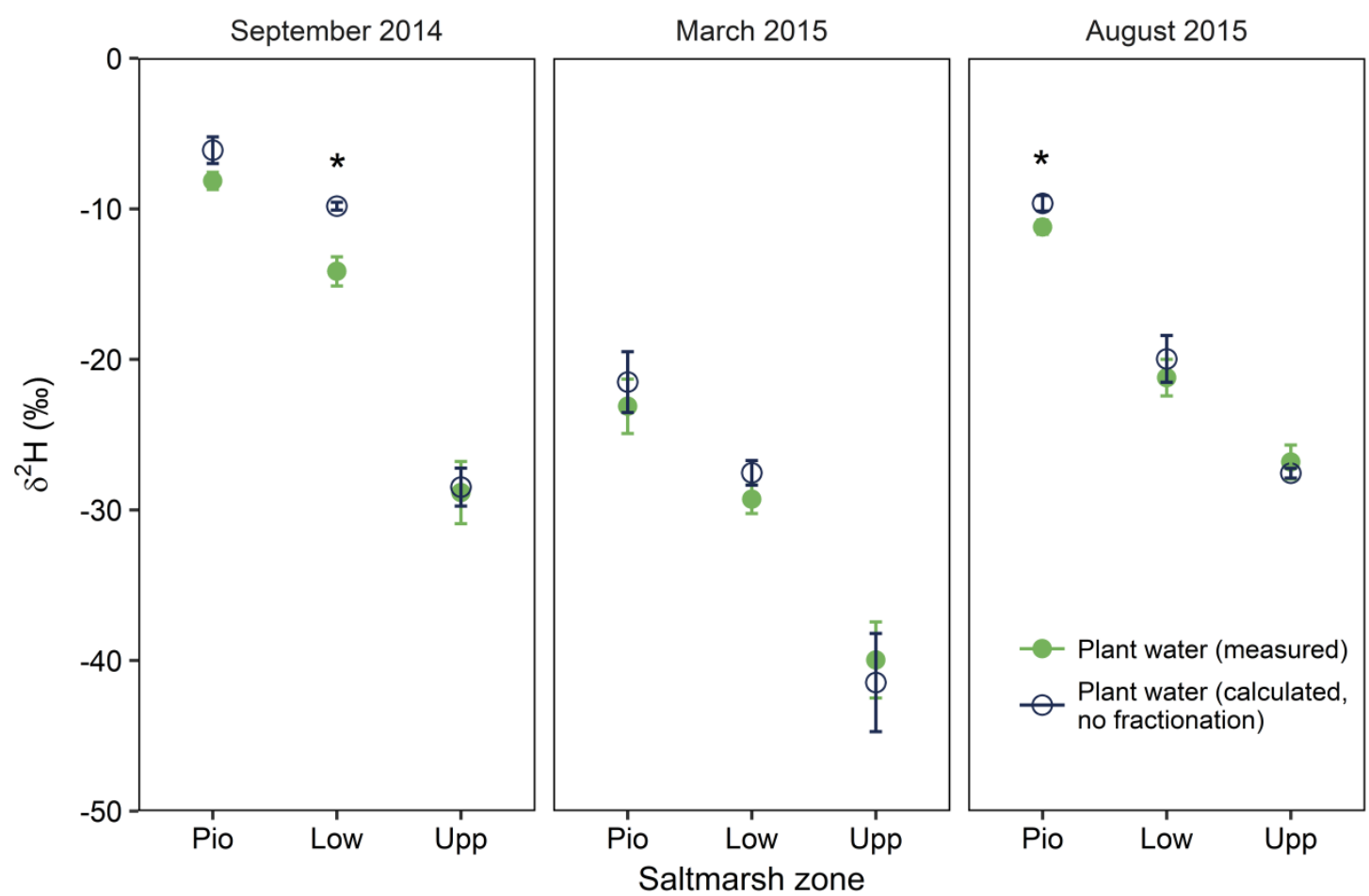

Figure 4.6: Difference among the three salt marsh zones between measured plant water $\delta^{2} \mathrm{H}$-values and plant water $\delta^{2} \mathrm{H}$-values calculated under the assumption of no ${ }^{2} \mathrm{H}$-discrimination during plant water uptake given for the three sampling campaigns. Asterisks indicate statistically significant differences between plant water and soil water $\delta^{2} \mathrm{H}$-values (Welch two sample t-test, $p<0.05$ ).

Although not as pronounced as in subtropical ecosystems, where water sources in the dry season are enriched in heavy isotopes compared to the wet season (Ewe et al. 2007), we also found seasonal variation in the isotope signature of sea and precipitation water. There was an enrichment in ${ }^{18} \mathrm{O}$ by about $+2 \%$ during the summer months caused by the higher evaporation in this period compared to the colder March sampling date. Precipitation and seawater $\delta^{18} \mathrm{O}$ signatures determined in our study were close to those measured by Röper et al. (2012) on Spiekeroog Island. 
Similar to Eley et al. (2014) and Romero and Feakins (2011) we also found increasing isotopic enrichment in xylem water with increasing inundation time of the habitat. The xylem $\delta^{2} \mathrm{H}$ values recorded in our study (from $-8 \%$ in S. anglica to approx. $-28 \%$ in E. atherica in summer, and from $23 \%$ in $S$. anglica to approx. $-40 \%$ in E. atherica in spring) are comparable to values found by Eley et al. (2014) in a UK salt marsh, where values ranged from approx. $-10 \%$ in S. anglica to approx. $-40 \%$ in E. atherica. Based on this gradient in isotopic ratios, we found a decreasing use of seawater by plants with increasing distance from the sea, a result that was consistent over all sampling dates and was valid for both the control plots and the experimental islands. This confirms our first hypothesis that pioneer zone species take up larger proportions of saline water compared to species in the higher marsh. This may result from the greater availability of seawater in lower marsh sediments, and is likely enhanced by a set of adaptations, which allow the lower marsh species to tolerate seawater. S. anglica from the pioneer zone has been found to be able to excrete $60 \%$ of the absorbed sodium ions by salt glands (Rozema et al. 1981; Rozema et al. 1985) and is thus more efficient in desalinization than most plants from the higher marsh. Moreover, the photosynthetic apparatus of Spartina species has been found to be relatively insensitive to salt, and the species can utilize additional carbon sources for photosynthesis such as dissolved bicarbonate from sediment which is fixed during a dark reaction in the roots (Hwang and Morris 1992). Therefore, S. anglica reaches high productivity in the frequently flooded pioneer zone and is able to utilize temporarily almost exclusively seawater as its water source. In contrast, the growth rate of E. atherica from the upper salt marsh is strongly reduced under seawater flooding (Rozema et al. 1985). This species is restricted to the upper marsh where freshwater is more readily available. A. portulacoides dominates the lower salt marsh zone in ungrazed marshes and thus also requires tolerance to anoxia and abundance of saline water in the rhizosphere. This species copes with saline conditions by accumulating osmotic solutes such as proline and methylated quaternary ammonium compounds (Rozema et al. 1985; Stewart and Lee 1974), and by developing salt succulence. We found up to $95 \%$ seawater use by this species which is comparable to the proportion of seawater use of $S$. anglica. The water use patterns of $S$. anglica, A. portulacoides and E. atherica along the salt marsh elevation gradient reflect differences in the availability of water sources in the three habitats due to the local inundation regimes. This suggests that the distribution of species along the salt marsh gradient is linked to species different abilities to cope with saline water sources. The finding that seawater uptake reduces with increasing distance from the sea has also been made in coastal dune vegetation (Greaver and Sternberg 2006). To ascertain that these patterns are due to species-specific differences in the choice of water sources within a given habitat caused by different physiological adaptations to salinity, further investigations with additional species from the different salt marsh habitats are needed. 
Our hypothesis predicting that there are seasonal shifts in the use of plant water sources with higher seawater uptake in drier months could only partly be confirmed. The effect of sampling season on the plants' water sources was not significant (Table 4.2). This may be due to the absence of long rainless periods during the summer months in the studied salt marsh (Fig. S4.2). However, the difference among the species in the type of water sources used was more distinct in late summer (significant difference among all three species). The increased use of seawater in summer by $S$. anglica compared to spring may be caused by a larger demand for water in this large-leaved grass species during the growing season in summer, but limited access to fresh water may also be a reason.

On the experimental islands, A. portulacoides showed an increased use of seawater on all three height levels compared to the respective plots in the natural salt marsh (significant at the lower and upper salt marsh level). We explain this difference partly by a more rapid runoff and drainage of precipitation in the artificial islands and thus a reduced availability of precipitation water. While the uptake of seawater by $A$. portulacoides in the pioneer zone level of the experimental islands was comparable to that of $S$. anglica at this elevation in the natural marsh, the species used less seawater in the upper height level of the experimental islands than in its natural habitat (the lower salt marsh). This evidences a high flexibility of $A$. portulacoides in its use of water sources (56-91\% seawater usage) under varying environmental conditions, confirming our fourth hypothesis, and may be one cause of the high competitiveness of $A$. portulacoides in the ungrazed lower salt marsh. The results also suggest that $A$. portulacoides may be able to tolerate rising water levels in the course of climate change to a considerable extent. Nevertheless, high flooding in the lowermost pioneer zone appears to represent a stress factor threatening the species as Balke et al. (2017) observed a rapid dieback of $A$. portulacoides from transplanted sods of lower salt marsh vegetation. The flexible use of variable water sources may represent one component of a high physiological plasticity of salt marsh plants in response to rising water levels. Other factors such as the tidal range and the amount of sediment trapped by the vegetation and thus its potential to grow upwards will be further factors which decide on the fate of salt marshes in a future warmer climate (Roman 2017; Reed 1995; Kirwan et al. 2016). In addition to the identification of water sources, we also used stable isotopes to identify the soil depth of maximum plant water uptake. To adopt such an approach, the isotopic signature of soil water must show a clear vertical gradient (Ehleringer and Dawson 1992). Due to evaporation from the soil surface, topsoil water is typically enriched in heavy isotopes and soil water contains decreasing amounts of heavy isotopes with increasing soil depth. In contrast to this pattern observed in terrestrial ecosystems, we mostly found an increase in $\delta^{18} \mathrm{O}$-values from the topsoil to deeper soil layers, which means that deeper soil layers were enriched in heavy isotopes. Since higher $\delta^{18} \mathrm{O}$ values typically indicate a higher salinity of the water (Ewe et al. 2007; Zhai et al. 2016) we assume that at our salt 
marsh site deeper soil layers are saturated with saline water richer in heavy isotopes due to regular inundation, while topsoil layers get depleted in heavy isotopes by precipitation water. Nevertheless, a gradient in the isotopic signature of soil water was detected in our study, enabling us to predict plant soil water uptake depth by means of a Bayesian calibrated stable isotope mixing model. The results of this model reveal that the major source of plant water was the topsoil layer in all salt marsh zones and during almost all sampling dates. The absence of a difference in plant water uptake depth among sampling seasons indicates that salt marsh plants are not significantly affected by water shortage during the summer months in this temperate salt marsh (Fig. S4.2). Thus, there is no need for enhanced water uptake from deeper soil layers with high concentrations of potentially toxic compounds, i.e. sulfide, during summer. Several studies in grasslands have shown that grassland species rather rely on water from the uppermost soil horizons than shifting water use to deeper soil layers under drought conditions (Prechsl et al. 2015; Eggemeyer et al. 2009; Kulmatiski and Beard 2013), whereas trees exhibit greater seasonal plasticity in the sources of water uptake (Eggemeyer et al. 2009). In the Everglades, three woody or herbaceous plant species used topsoil water rich in freshwater during the wet season, whereas in the dry season, only the mangrove tree species switched to groundwater usage; the grass and herb species continued using topsoil water, which was hypersaline at this time (Ewe et al. 2007). Therefore, regardless of a pronounced drought effect in the summer months, seasonal shifts in the preferred depth of water uptake may not necessarily be expected in the three salt marsh species (two grasses and a dwarf shrub) of our study.

In general, we found a decrease in the proportion of water taken up per soil volume with increasing soil depth in all three salt marsh zones. This is largely explained by the decrease in fine root mass per volume towards deeper soil (Redelstein et al. 2018). Across all data points from the natural salt marsh and the experimental islands, the relative contribution of plant water uptake in a given soil layer was correlated positively $\left(p<0.001\right.$, adj. $\left.\mathrm{r}^{2}=0.90\right)$ with the proportion of fine root mass in that soil layer. Even though the variation among plots in the relative contribution of a soil depth to water uptake was relatively large (Fig. 4.4), it appears that deeper roots differed not systematically from topsoil roots in their water uptake per root mass as suggested by Fig. 4.5b. In contrast, across all study plots, the roots in 20-30 cm depth tended to take up more water per root mass than those at upper soil depths. We had expected that roots in deeper salt marsh soil layers would show reduced uptake activity due to longlasting anoxia and potential metal and $\mathrm{S}^{-2}$ toxicity. Preferential uptake in topsoil layers could at least temporarily reduce these harmful effects. A reduced hydraulic conductivity of roots could be another reason for lowered specific water uptake rates per root mass in deeper horizons, as has been observed in mesic, non-saline grasslands (Nippert et al. 2012). Our results suggest that the studied salt marsh plants can maintain root physiological activity despite the unfavorable environmental conditions 
encountered in the deeper sediment. Development of extensive aerenchymatic tissue in the roots and $\mathrm{O}_{2}$ release to the sediment, which oxidizes toxic compounds, may be one adaptation to maintain root activity in anoxic sediments. The pioneer zone species Spartina anglica, for example, is pursuing such a strategy (Lee 1999; Koop-Jakobsen and Wenzhoefer 2015). The example of this euhalophytic $\mathrm{C} 4$ grass shows that very high carbon assimilation rates (up to $27 \mu \mathrm{mol} \mathrm{CO}_{2} \mathrm{~m}^{-2} \mathrm{~s}^{-1}$ ) and productivities (up to $6000 \mathrm{~g} \mathrm{d.m.} \mathrm{m}^{-2} \mathrm{yr}^{-1}$, Long and Woolhouse 1979) are possible, even if seawater contributes by 80 to $99 \%$ to water uptake.

\section{Conclusions}

Our study shows that the vegetation zonation in temperate salt marshes along elevation and inundation gradients is linked to a gradient in the availability of water sources used by the plants, which may separate obligate halophytes (euhalophytes), facultative halophytes and halotolerant species by their physiological ability to cope with saline water sources. Physiological experiments have to show whether the apparent preference of seawater or precipitation water in lower and higher salt marshes is largely determined by the abundance of the different water sources, or caused by species-specific physiological preference or avoidance. Through a transplantation experiment with the dominant lower salt marsh species A. portulacoides, we demonstrated on experimental islands that certain salt marsh species are capable of using a broad range of water sources. This likely enables them to cope with increasing levels of flooding and salinity in the course of sea level rise.

\section{Acknowledgements}

We like to thank the administration of the Lower Saxony Wadden Sea National Park for giving the permission for study and granting access to the field sampling sites. This work was part of the project "BEFmate" (Biodiversity and Ecosystem Functioning across marine and terrestrial ecosystems) funded by the Ministry for Science and Culture of Lower Saxony, Germany, under project number ZN2930. Financial support is gratefully acknowledged.

\section{Conflict of interest}

The authors declare that they have no conflict of interest. 


\subsection{Supplementary Material}
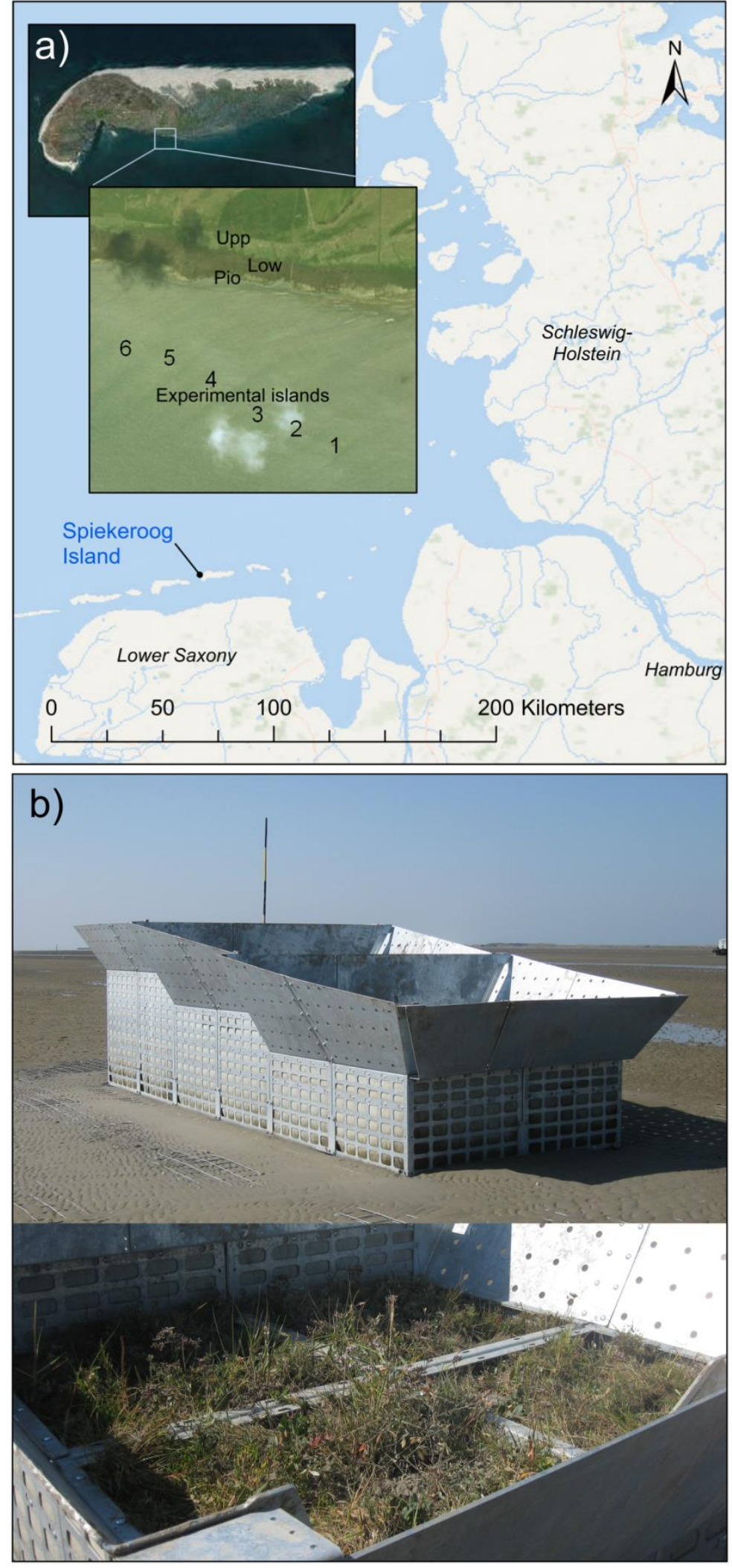

Figure S4.1: a) Location of Spiekeroog Island on the German North Sea coast and close-up of sampling plot locations (upper salt marsh (Upp), lower salt marsh (Low), pioneer zone (Pio), experimental islands) on the south side of the barrier island. The location of the experimental islands is indicated by the numbers 1-6 (Service layer Credits: Esri, DeLorme, GEBCO, NOAA, NGDB, and other contributors, Source: Esri, DigitalGlobe, GeoEye, Earthstar Geographics, CNES/Airbus DS, USDA, USGS, AeroGRD, IGN, and the GIS User Community). b) Setup of experimental islands and close-up of the steel cages planted with vegetation from the lower salt marsh (photographs: R. Redelstein). 


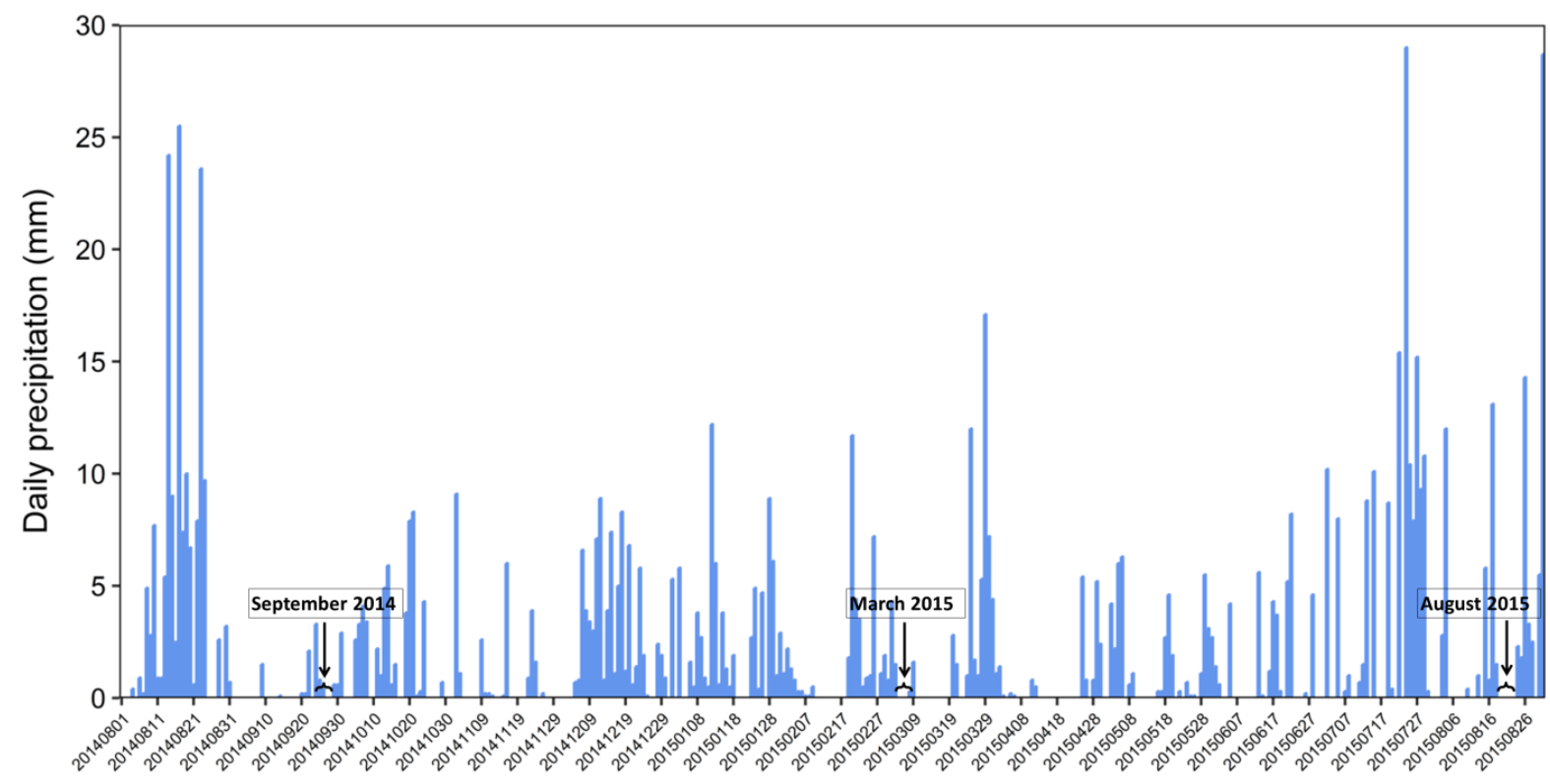

Figure S4.2: Daily precipitation during the year of sampling campaigns from September 2014 to August 2015. Sampling campaigns are marked by arrows. Data were obtained from the German Meteorological Service (Deutscher Wetterdienst) and represent values for Norderney, $40 \mathrm{~km}$ apart from our sampling location (http://www.dwd.de/DE/leistungen/klimadatendeutschland/klarchivtagmonat.html?nn=16102).

Table S4.1: Monthly precipitation during the year of sampling campaigns from September 2014 to August 2015. Annual precipitation from September 2014 to August 2015 was $706 \mathrm{~mm}$.

\begin{tabular}{lc}
\hline Month & Monthly precipitation (mm) \\
\hline September 2014 & 9.8 \\
October 2014 & 57.8 \\
November 2014 & 26.0 \\
December 2014 & 83.9 \\
January 2015 & 79.0 \\
February 2015 & 38.8 \\
March 2015 & 64.4 \\
April 2015 & 18.8 \\
May 2015 & 43.8 \\
June 2015 & 39.6 \\
July 2015 & 148.0 \\
August 2015 & 95.8 \\
\hline
\end{tabular}



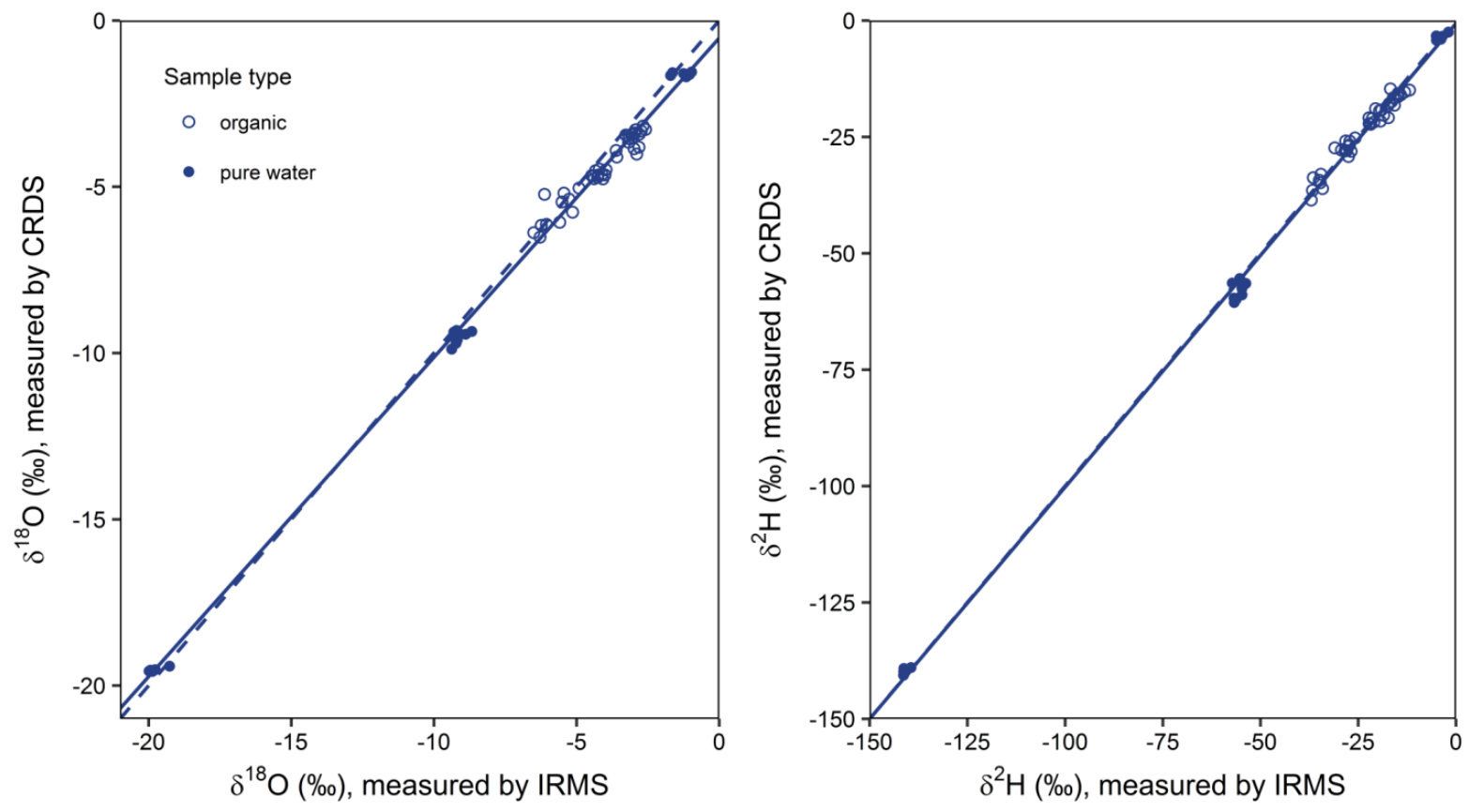

Figure S4.3: Comparison of $\delta$-values of ${ }^{18} \mathrm{O}$ and ${ }^{2} \mathrm{H}$ measured by a Picarro L2120-i water analyzer (CRDS) with values measured by isotope ratio mass spectroscopy (IRMS) of pure water samples (filled circles) and water extracted from organic samples (soil and root material, open circles). Data were organic-corrected. Solid lines represent a linear regression model (Model II, ranged major axis) with $y=0.96 \mathrm{x}-0.53, \mathrm{R}^{2}=0.996\left(\delta^{18} \mathrm{O}\right)$ and $y=0.996 x-0.63, R^{2}=0.998\left(\delta^{2} H\right)$. Dashed lines give the 1:1 reference line (slope 1, intercept 0 ).

Table S4.2 Mean difference between $\delta$-values of ${ }^{18} \mathrm{O}$ and ${ }^{2} \mathrm{H}$ measured by cavity ring-down spectroscopy (CRDS) and values measured by isotope ratio mass spectroscopy (IRMS) for pure water samples and water samples with potential organic contamination

\begin{tabular}{lccc}
\hline & $\begin{array}{c}\Delta \boldsymbol{\delta}^{\mathbf{1 8}} \mathbf{O}(\%) \\
\text { Mean diff (IRMS-CRDS) } \pm \mathbf{s e}\end{array}$ & $\begin{array}{c}\Delta \boldsymbol{\delta}^{\mathbf{2}} \mathbf{H}(\%) \\
\text { Mean diff (IRMS-CRDS) } \pm \mathbf{s e}\end{array}$ & $\mathrm{n}$ \\
\hline Pure water & $0.354 \pm 0.035$ & $2.311 \pm 0.320$ & 24 \\
Soil water & $0.367 \pm 0.041$ & $1.787 \pm 0.219$ & 24 \\
Plant water & $0.515 \pm 0.071$ & $1.023 \pm 0.214$ & 18 \\
\hline
\end{tabular}




\section{References}

Armstrong W, Wright EJ, Lythe S, Gaynard TJ (1985) Plant zonation and the effects of the springneap tidal cycle on soil aeration in a humber salt-marsh. Journal of Ecology 73:323-339.

Balke T, Lõhmus K, Hillebrand H, Zielinski O, Haynert K, Meier D, Hodapp D, Minden V, Kleyer M (2017) Experimental salt marsh islands: A model system for novel metacommunity experiments. Estuarine, Coastal and Shelf Science 198:288-298. doi:10.1016/j.ecss.2017.09.021.

Barbier EB, Hacker SD, Kennedy C, Koch EW, Stier AC, Silliman BR (2011) The value of estuarine and coastal ecosystem services. Ecological Monographs 81:169-193. doi:10.1890/10-1510.1.

Barnard RL, Bello F de, Gilgen AK, Buchmann N (2006) The $\delta^{18} \mathrm{O}$ of root crown water best reflects source water $\delta^{18} \mathrm{O}$ in different types of herbaceous species. Rapid Communications in Mass Spectrometry 20:3799-3802. doi:10.1002/rcm.2778.

Cooper A (1982) The effects of salinity and waterlogging on the growth and cation uptake of salt marsh plants. New Phytologist 90:263-275.

Craig H (1961) Isotopic variations in meteoric waters. Science (New York) 133:1702-1703. doi:10.1126/science.133.3465.1702.

Dalton FN (1988) Plant root water extraction studies using stable isotopes. Plant and Soil 111:217221.

Dawson TE, Ehleringer JR (1991) Streamside trees that do not use stream water. Nature 350:335337.

Dawson TE, Ehleringer JR (1993) Isotopic enrichment of water in the woody tissues of plants implications for plant water source, water uptake, and other studies which use the stable isotopic composition of cellulose. Geochimica et Cosmochimica Acta 57:3487-3492.

Dawson TE, Mambelli S, Plamboeck AH, Templer PH, Tu KP (2002) Stable isotopes in plant ecology. Annual Review of Ecology and Systematics 33:507-559. doi:10.1146/annurev.ecolsys.33.020602.095451.

DWD Deutscher Wetter Dienst, http://www.dwd.de/DE/leistungen/klimadatendeutschland/klarchivtagmonat.html?nn=16102.

Eggemeyer KD, Awada T, Harvey FE, Wedin DA, Zhou X, Zanner CW (2009) Seasonal changes in depth of water uptake for encroaching trees Juniperus virginiana and Pinus ponderosa and two dominant $\mathrm{C}_{4}$ grasses in a semiarid grassland. Tree Physiology 29:157-169. doi:10.1093/treephys/tpn019.

Ehleringer JR, Dawson TE (1992) Water uptake by plants: perspectives from stable isotope composition. Plant, Cell and Environment 15:1073-1082.

Eley Y, Dawson L, Black S, Andrews J, Pedentchouk N (2014) Understanding ${ }^{2} \mathrm{H} /{ }^{1} \mathrm{H}$ systematics of leaf wax n-alkanes in coastal plants at Stiffkey saltmarsh, Norfolk, UK. Geochimica et Cosmochimica Acta 128:13-28. doi:10.1016/j.gca.2013.11.045. 
Ellsworth PZ, Williams DG (2007) Hydrogen isotope fractionation during water uptake by woody xerophytes. Plant and Soil 291:93-107. doi:10.1007/s11104-006-9177-1.

Ewe SML, Sternberg LdSL, Childers DL (2007) Seasonal plant water uptake patterns in the saline southeast Everglades ecotone. Oecologia 152:607-616. doi:10.1007/s00442-007-0699-x.

Flowers TJ (1985) Physiology of halophytes. Plant and Soil 89:41-56.

Flowers TJ, Colmer TD (2008) Salinity tolerance in halophytes. New Phytologist 179:945-963. doi:10.1111/j.1469-8137.2008.02531.x.

Greaver TL, Sternberg LdSL (2006) Linking marine resources to ecotonal shifts of water uptake by terrestrial dune vegetation. Ecology 87:2389-2396.

Greaver TL, Sternberg LdSL (2007) Fluctuating deposition of ocean water drives plant function on coastal sand dunes. Global Change Biology 13:216-223. doi:10.1111/j.1365-2486.2006.01287.x.

Gröning M, Lutz HO, Roller-Lutz Z, Kralik M, Gourcy L, Pöltenstein L (2012) A simple rain collector preventing water re-evaporation dedicated for $\delta^{18} \mathrm{O}$ and $\delta^{2} \mathrm{H}$ analysis of cumulative precipitation samples. Journal of Hydrology 448-449:195-200. doi:10.1016/j.jhydrol.2012.04.041.

Hajibagheri MA, Yeo AR, Flowers TJ (1985) Salt tolerance in Suaeda maritima (L.) Dum. finestructure and ion concentrations in the apical regions of roots. New Phytologist 99:331-343.

Hwang YH, Morris JT (1992) Fixation of inorganic carbon from different sources and its translocation in Spartina alterniflora Loisel. Aquatic Botany 43:137-147.

Ingraham NL, Shadel C (1992) A comparison of the toluene distillation and vacuum/heat methods for extracting soil water for stable isotopic analysis. Journal of Hydrology 140:371-387. doi:10.1016/0022-1694(92)90249-U.

Kirwan ML, Guntenspergen GR, D’Alpaos A, Morris JT, Mudd SM, Temmerman S (2010) Limits on the adaptability of coastal marshes to rising sea level. Geophysical Research Letters 37:L23401. doi:10.1029/2010GL045489.

Kirwan ML, Temmerman S, Skeehan EE, Guntenspergen GR, Fagherazzi S (2016) Overestimation of marsh vulnerability to sea level rise. Nature Climate Change 6:253-260. doi:10.1038/NCLIMATE2909.

Koeniger P, Marshall JD, Link T, Mulch A (2011) An inexpensive, fast, and reliable method for vacuum extraction of soil and plant water for stable isotope analyses by mass spectrometry. Rapid Communications in Mass Spectrometry 25:3041-3048. doi:10.1002/rcm.5198.

Koop-Jakobsen K, Wenzhoefer F (2015) The dynamics of plant-mediated sediment oxygenation in Spartina anglica rhizospheres-a planar optode study. Estuaries and Coasts 38:951-963. doi:10.1007/s12237-014-9861-y.

Kulmatiski A, Beard KH (2013) Root niche partitioning among grasses, saplings, and trees measured using a tracer technique. Oecologia 171:25-37. doi:10.1007/s00442-012-2390-0.

Ladd SN, Sachs JP (2015) Influence of salinity on hydrogen isotope fractionation in Rhizophora mangroves from Micronesia. Geochimica et Cosmochimica Acta 168:206-221. doi:10.1016/j.gca.2015.07.004. 
Lee RW (1999) Oxidation of sulfide by Spartina alterniflora roots. Limnology and Oceanography 44:1155-1159.

Leuschner C, Ellenberg H (2017) Ecology of Central European Non-Forest Vegetation: Coastal to Alpine, Natural to Man-Made Habitats. Vegetation Ecology of Central Europe Volume II. Chapter 1: Salt Marshes and Inland Saline Habitats. Springer Nature, Cham.

Lin G, Sternberg LdSL (1993) Hydrogen isotopic fractionation by plant roots during water uptake in coastal wetland plants. In Stable Isotopes and Plant Carbon-Water Relations (eds j.R. Ehleringer, A.E. Hall \& G.D. Farquhar). Academic Press Inc., San Diego:497-510.

Long SP, Woolhouse HW (1979) Primary production in Spartina marshes. In: Jefferies RL, Davy AJ (eds) Ecological Processes in Coastal Environments. Blackwell, Oxford:33-352.

Martin-Gomez P, Barbeta A, Voltas J, Penuelas J, Dennis K, Palacio S, Dawson TE, Ferrio JP (2015) Isotope-ratio infrared spectroscopy: a reliable tool for the investigation of plant-water sources? New Phytologist 207:914-927. doi:10.1111/nph.13376.

Mcleod E, Chmura GL, Bouillon S, Salm R, Bjork M, Duarte CM, Lovelock CE, Schlesinger WH, Silliman BR (2011) A blueprint for blue carbon: toward an improved understanding of the role of vegetated coastal habitats in sequestering $\mathrm{CO}_{2}$. Frontiers in Ecology and the Environment 9:552560. doi:10.1890/110004.

Möller I, Spencer T, French, JR, Leggett DJ, Dixon M (1999) Wave transformation over salt marshes: A field and numerical modelling study from north Norfolk, England. Estuarine, Coastal and Shelf Science 49:411-426.

Morris JT, Sundareshwar PV, Nietch CT, Kjerfve B, Cahoon (2002) Responses of coastal wetlands to rising sea level. Ecology 83:2869-2877.

Munns R, Tester M (2008) Mechanisms of salinity tolerance. Annual review of plant biology 59:651681. doi:10.1146/annurev.arplant.59.032607.092911.

Nelson JL, Zavaleta ES (2012) Salt marsh as a coastal filter for the oceans: changes in function with experimental increases in nitrogen loading and sea-level rise. PloS one 7:e38558. doi:10.1371/journal.pone.0038558.

Nippert JB, Wieme RA, Ocheltree TW, Craine JM (2012) Root characteristics of $\mathrm{C}_{4}$ grasses limit reliance on deep soil water in tallgrass prairie. Plant and Soil 355:385-394. doi:10.1007/s11104011-1112-4.

Oost A, Kabat P, Wiersma A, Hofstede J (2009) Climate Change Thematic Report No. 4.1. In: Marencic H., de Vlas J. (eds) Wadden Sea Quality Status Report. Wadden Sea Ecosystems No. 25.

Orlowski N, Frede H-G, Brüggemann N, Breuer L (2013) Validation and application of a cryogenic vacuum extraction system for soil and plant water extraction for isotope analysis. Journal of Sensors and Sensor Systems 2:179-193. doi:10.5194/jsss-2-179-2013.

Parnell AC, Inger R, Bearhop S, Jackson AL (2010) Source partitioning using stable isotopes: coping with too much variation. PloS one 5:e9672. doi:10.1371/journal.pone.0009672. 
Prechsl UE, Burri S, Gilgen AK, Kahmen A, Buchmann N (2015) No shift to a deeper water uptake depth in response to summer drought of two lowland and sub-alpine $\mathrm{C}_{3}$-grasslands in Switzerland. Oecologia 177:97-111. doi:10.1007/s00442-014-3092-6.

R Development Core Team (2016) R: A Language and Environment for Statistical Computing. R Foundation for Statistical Computing, Vienna, Austria, https://www.R-project.org/.

Redelstein R, Dinter T, Hertel D, Leuschner C (2018) Effects of Inundation, Nutrient Availability and Plant Species Diversity on Fine Root Mass and Morphology Across a Saltmarsh Flooding Gradient. Frontiers in Plant Science 9:98. doi:10.3389/fpls.2018.00098.

Reed DJ (1995) The response of coastal marshes to sea-level rise: survival or submergence? Earth Surface Processes and Landforms 20:39-48.

Roman CT (2017) Salt marsh sustainability: Challenges during an uncertain future. Estuaries and Coasts 40:711-716. doi:10.1007/s12237-016-0149-2.

Romero IC, Feakins SJ (2011) Spatial gradients in plant leaf wax D/H across a coastal salt marsh in southern California. Organic Geochemistry 42:618-629. doi:10.1016/j.orggeochem.2011.04.001.

Röper T, Kröger KF, Meyer H, Sültenfuss J, Greskowiak J, Massmann G (2012) Groundwater ages, recharge conditions and hydrochemical evolution of a barrier island freshwater lens (Spiekeroog, Northern Germany). Journal of Hydrology 454-455:173-186. doi:10.1016/j.jhydrol.2012.06.011.

Rozema J, Bijwaard P, Prast G, Broekman R (1985) Ecophysiological adaptations of coastal halophytes from foredunes and salt marshes. Vegetatio 62:499-521.

Rozema J, Gude H, Pollak G (1981) An ecophysiological study of the salt secretion of 4 halophytes. New Phytologist 89:201-217.

Santini NS, Reef R, Lockington DA, Lovelock CE (2015) The use of fresh and saline water sources by the mangrove Avicennia marina. Hydrobiologia 745:59-68. doi:10.1007/s10750-014-2091-2.

Sternberg LdSL, Ish-Shalom-Gordon N, Ross M, O’Brien J (1991) Water relations of coastal plant communities near the ocean/freshwater boundary. Oecologia 88:305-310. doi:10.1007/BF00317571.

Sternberg LdSL, Swart PK (1987) Utilization of freshwater and ocean water by coastal plants of southern Florida. Ecology 68:1898-1905.

Stewart GR, Lee JA (1974) The role of proline accumulation in halophytes. Planta 120:279-289. doi:10.1007/BF00390296.

Ungar IA (1998) Are biotic factors significant in influencing the distribution of halophytes in saline habitats? The Botanical Review 64:176-199. doi:10.1007/BF02856582.

Wei L, Lockington DA, Poh S-C, Gasparon M, Lovelock CE (2013) Water use patterns of estuarine vegetation in a tidal creek system. Oecologia 172:485-494. doi:10.1007/s00442-012-2495-5.

White JW, Cook ER, Lawrence, JR, Broecker WS (1985) The D/H ratios of sap in trees Implications for water sources and tree-ring $\mathrm{D} / \mathrm{H}$ ratios. Geochimica et Cosmochimica Acta 49:237-246. 
Zhai L, Jiang J, DeAngelis D, da Silveira Lobo Sternberg L (2016) Prediction of Plant Vulnerability to Salinity Increase in a Coastal Ecosystem by Stable Isotope Composition $\left(\delta^{18} \mathrm{O}\right)$ of Plant Stem Water. A Model Study. Ecosystems 19:32-49. doi:10.1007/s10021-015-9916-3. 
CHAPTER 4 


\section{Chapter}
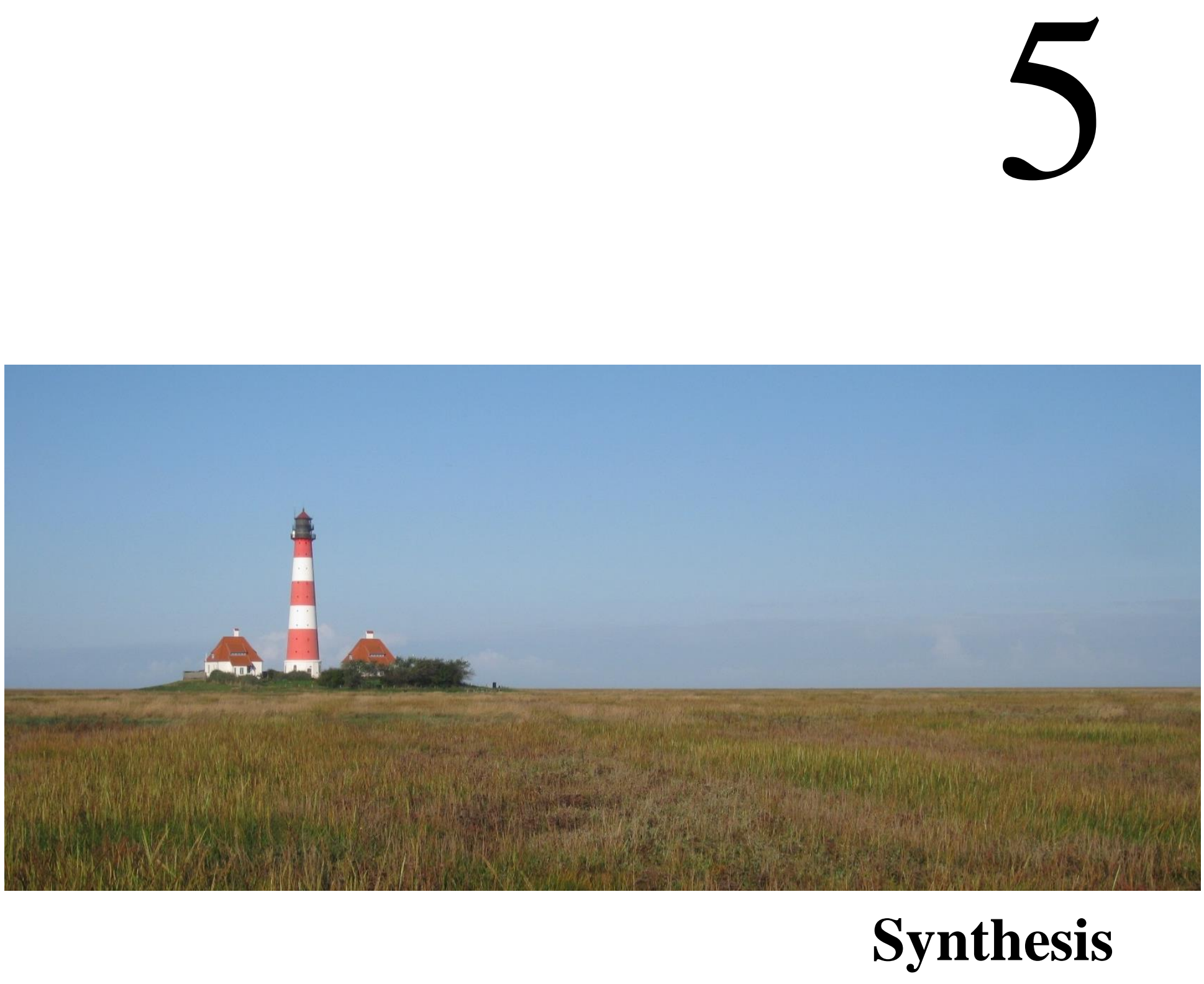


\section{Synthesis}

Salt marshes are habitats with harsh environmental conditions which require high degrees of adaptation of inhabiting species. As the plant below-ground compartment plays a major component in the interaction of plants with their abiotic environment, different aspects of root system structure and functions in saltmarsh plants were investigated within the presented $\mathrm{PhD}$-study: the role of root growth for the stability of seedlings in a sedimentary active environment (chapter 2), fine root traits and their relations to the abiotic environment (chapter 3), and the uptake of saline water sources of different plant species across the saltmarsh flooding gradient (chapter 4). The following chapter summarizes and discusses the results of the three studies and brings them in context with further results of the BEFmate project.

\subsection{Below-ground plant traits across the elevational saltmarsh gradient and their relation to the abiotic environment}

\section{Seedling stability}

The first crucial step for the establishment and development of a salt marsh is the germination and survival of seedlings on bare tidal flats. Wind and wave forces acting in salt marshes may dislodge recently germinated seedlings. Therefore, one major requisition for their survival is the rapid and stable anchorage of seedlings in the sediment. Balke et al. (2011 and 2013) pointed out that seedling survival on bare tidal flats is determined by the frequency and magnitude of sediment erosion and accretion events, and that propagules of mangroves need a disturbance free period (the so called 'Window of Opportunity') to rapidly develop roots that are long enough to withstand seedling dislodgement by flooding. In addition, we found that waterlogged sediment conditions may have an important species-specific impact on root growth and thus, on the stability of establishing seedlings. In our greenhouse experiment (chapter 2) it was shown that the upper saltmarsh species Elytrigia atherica showed fastest root (and shoot) growth and highest resistance towards erosion under favorable drained sediment conditions, but suffered strongest under waterlogged sediment conditions compared to Atriplex portulacoides and Salicornia europaea from the lower salt marsh and pioneer zone, respectively (Figs 2.3, 2.5). The stability of seedlings was significantly related to root length and biomass (Fig. 2.6). This indicates that the response of root growth of seedlings to waterlogged sediment conditions may be a first determinant for the distribution of species across the saltmarsh 
elevational and flooding gradient. Other determinants of species distribution include salinity tolerance (Cooper 1982; Katschnig et al. 2013; Redondo-Gómez et al. 2007; Rozema et al. 1985; Rozema and van Diggelen 1991) as well as inter-specific competition (Huckle et al. 2000; Balke et al. 2017), or herbivory (He et al. 2015). Within the BEFmate experiment it was shown that seedlings of four species besides $E$. atherica had established on bare plots enclosed in the upper salt marsh during the first growing season, a clear indication of competitive exclusion by the monospecific stands of $E$. atherica in established salt marshes (Balke et al. 2017). E. atherica seedlings, however, only established in the upper saltmarsh plots, underlining the species' sensitivity to the waterlogged soil conditions by reduced root growth in the lower salt marsh and pioneer zone, as shown in our experiment. Furthermore, the number of species and percentage of species presence were significantly higher on bare plots enclosed in the salt marsh compared to the more isolated experimental islands. This supports earlier results that not only seedling stability and physiological abilities to survive play a role in saltmarsh establishment, but also dispersal limitation (Rand 2000; Wolters et al. 2005; Mossman et al. 2012).

\section{Fine root mass}

Comparisons of data on root biomass in salt marshes from different studies result in great variability between saltmarsh sites. While the fine root mass in our study (chapter 3) ranged from 750 to $2500 \mathrm{~g} \mathrm{~m}^{-2}$ in all plots in the $0-40 \mathrm{~cm}$ profile (Fig. 3.2), Groenendijk and Vinklievaart (1987) found considerably higher values in $60 \mathrm{~cm}$ soil depth in a Dutch salt marsh $\left(7763 \mathrm{~g} \mathrm{~m}^{-2}-13,338 \mathrm{~g} \mathrm{~m}^{-2}\right)$. However, they found the same pattern of biomass distribution across the salt marsh communities as we did. Ford et al. (2016) found total root biomass values of 1500 to $8800 \mathrm{~g} \mathrm{~m}^{-2}$ in $30 \mathrm{~cm}$ soil depth in six saltmarsh sites at Morecambe Bay and Essex (GB). Further data on root biomass of European salt marshes with comparable species composition is scarce whereas several studies have investigated below-ground biomass of Spartina alterniflora in saltmarshes of the US with values ranging between $600 \mathrm{~g} \mathrm{~m}^{-2}$ and 11,000 $\mathrm{g} \mathrm{m}^{-2}$ (Tripathee and Schaefer 2015; Smith et al. 1979; Windham et al. 2003). However, it was noted that comparison of data from different studies must be viewed critically as methods in root sampling and processing (i.e. mesh size for washing of roots, distinction between dead and live roots, or the inclusion of rhizomes) vary strongly and furthermore, there is a great seasonal variability in root biomass in salt marshes.

Although comparisons of root biomass measurements between different studies may be limited due to methodological discrepancies, values on root biomass found in salt marshes are in general very high compared to those found in terrestrial grasslands. Rose et al. (2012) found below-ground biomass 
values of around $500 \mathrm{~g} \mathrm{~m}^{-2}$ in temperate pastures which is around $80 \%$ less compared to the highest values found in our study. From a selection of various ecosystems (deserts to tropical forests) Jackson et al. (1997) found the highest total fine root mass values in temperate grasslands $\left(1.51 \mathrm{~kg} \mathrm{~m}^{-2}\right)$ which is around $60 \%$ of the maximal values found in our study. Also root surface area totals found in our study (340 $\mathrm{m}^{2} \mathrm{~m}^{-2}$, Fig. 3.3) were partly more than 4-fold higher compared to those given by Jackson et al. (1997) for temperate grasslands $\left(79.1 \mathrm{~m}^{2} \mathrm{~m}^{-2}\right)$. With this we could, on the one hand, demonstrate that saltmarsh plants appear to have adaptation mechanisms of below-ground organs which successfully allow them to develop extensive root systems ensuring survival in their harsh environmental habitat. On the other hand, the results revealed that the multi-stress conditions in salt marshes require extremely high investment in root biomass of plants, for example for their stability in the mechanically strongly disturbed habitat. Furthermore, fine root mass was strongly dependent on soil texture and associated nutrient availability (Fig. 3.6): fine root mass was higher in the Spiekeroog marsh with sandy sediment and lower nutrient concentrations (Table 3.1). The fine root mass:aboveground biomass ratio generally exceeded unity and was higher at the Spiekeroog site than in Westerhever (Table 3.2). This indicates the increased investment in roots for nutrient uptake in the nutrient-poorer site which is in line with the optimal resource partitioning theory (Bloom et al. 1985): an increase of the root:shoot ratio reduces the demand of element supply of the above-ground part and increases the ability of the root to supply these elements. Furthermore, higher root biomass may be needed for plant anchorage in the sandy and thus more erosion-prone sediment of Spiekeroog.

\section{Effect of biodiversity}

In our inventory of fine roots (chapter 3), maxima in fine root mass at both sites were found in the lower marsh with highest plant species richness. This positive correlation of fine root mass and plant species richness $(p<0.01$, Table 3.4) is an indicator of an existing effect of biodiversity in the salt marsh as also found in several previous studies for different ecosystems (Hector et al. 2010; Hooper et al. 2005; Cardinale et al. 2006). The comparably high species number in the lower salt marsh appears to increase root biomass by possibly promoting soil exploitation through root space partitioning. Several studies exist which have made similar findings, indicating an impact of species richness on ecosystem productivity via the 'complementarity effect' (Loreau and Hector 2001; Steudel et al. 2011): niche differentiation or facilitation between species increases the performance of communities and may thus increase primary production. In a mesocosm experiment with saltmarsh plant species a significant increase in root biomass and the root:shoot ratio was found with increasing number of species (Sullivan et al. 2007). Ford et al. (2016) found plant species richness to be a 
significant predictor of root biomass in a UK salt marsh and similar findings were made by $\mathrm{Hu}$ et al. (2013) and Pohl et al. (2009) for steppe and alpine grasslands, respectively. All of these studies, as well as several further studies (Gould et al. 2016; Chen et al. 2012; Coops et al. 1996) showed a positive effect of plant species richness and an extensive root network on soil stability and reduction of soil erosion rates. This underlines the importance of maintaining species diverse saltmarsh sites for improved soil stability and the provision of further important ecosystem functions. Additionally, more diverse communities have a higher potential to buffer ecosystem processes in the face of changing environmental conditions (Steudel et al. 2011; Hector et al. 2010).

The pattern of diversity distribution across the flooding gradient in the ungrazed saltmarsh sites with highest diversity in the lower salt marsh corresponds to the intermediate disturbance hypothesis (Grime 1973; Connell 1978). According to this hypothesis species diversity is low at high physical disturbances due to high mortality of species caused by environmental stress (i.e. in the pioneer zone), and at low physical disturbance because of strongly competitive species which exclude other species (i.e. in the upper salt marsh). Thus, diversity peaks at intermediate intensities and frequencies of physical disturbance (i.e. in the lower salt marsh).

One indicator for root space partitioning would be to test the hypothesis that competition for water in more species rich zones leads to water uptake from different soil depths by different species according to the niche complementarity theory (Loreau and Hector 2001). Determining the depth of water uptake by the use of stable isotopes as in our study (chapter 4) for different species in the lower saltmarsh community, would be one tool to investigate competition for water sources, i.e. complementary water use in relation to diversity of saltmarsh communities. This would be of special interest regarding the experimental islands where a competition based system with higher species number was artificially created by planting sods from the lower salt marsh to the upper saltmarsh level of the islands. There are several studies which have found strong evidence for plant water partitioning in regions with limited water supply (Kulmatiski et al. 2010; Moreno-Gutierrez et al. 2012; West et al. 2012; Dodd et al. 1998; Nippert and Knapp 2007; Schwendenmann et al. 2010). In contrast, Bachmann et al. (2015) found no support for the hypothesis of increased complementarity in water use in more diverse than in less diverse communities of temperate grassland species. At this time of the BEFmate experiment, no competitive exclusion of plant species could be observed yet on the experimental islands (Balke et al. 2017). Further investigations on soil depths of plant water uptake could indicate whether there is competition for fresh water on upper levels of the experimental islands and whether plants adjust their water uptake patterns due to inter-specific competition leading to niche separation in the further course of the experiment. 
Regarding the rapid spread of the native grass E. atherica forming almost monospecific stands in the upper marsh, we showed that this reduces below-ground biomass (chapter 3) as well as belowground carbon and nitrogen pools stored in fine roots (Fig. 5.1), and soil organic carbon and nitrogen contents (Table 3.1).

a)

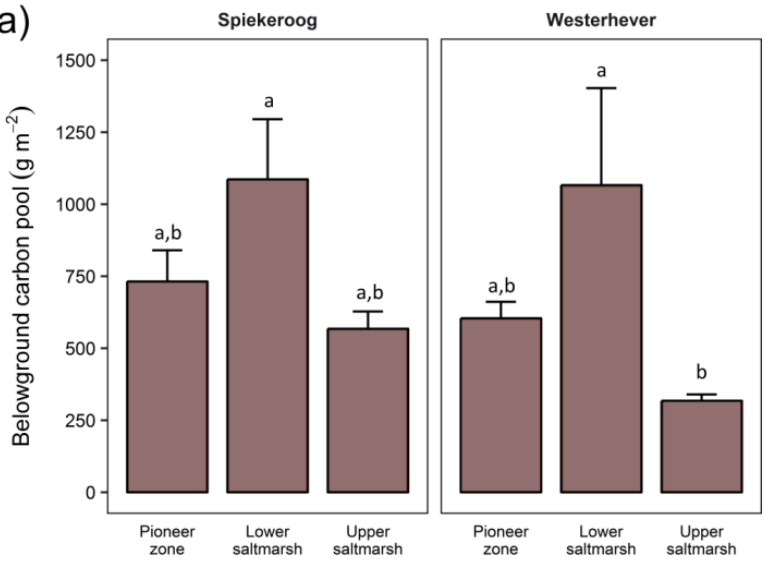

Figure 5.1: Below-ground carbon (a) and nitrogen b)

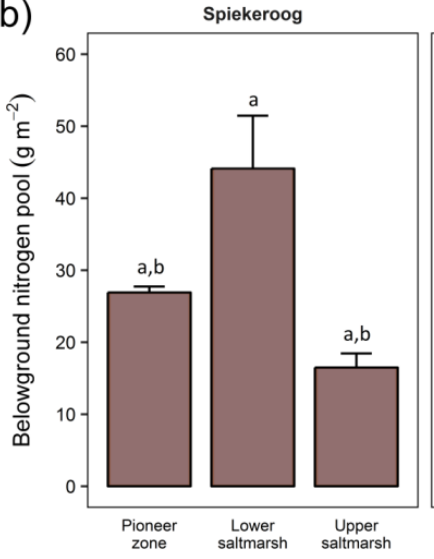

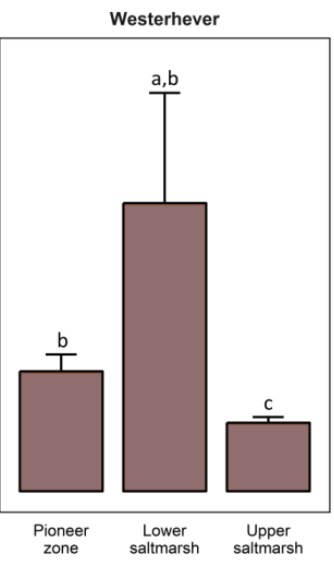

(b) pools in fine root mass in the three saltmarsh communities at the two study sites (means \pm SE). Different letters indicate significant differences between communities (one-way ANOVA with Tukey's post-hoc test, $p<0.05$ ).

Although above-ground productivity and litter biomass of E. atherica has been found to be significantly increased compared to control communities dominated by A. portulacoides or Puccinellia maritima, carbon mineralization in the sediment below the E. atherica community was decreased (Valery et al. 2004). This is due to the very lignin rich litter of this species with slow decay rates leading to a trapping of carbon and nitrogen in the litter so that nutrients remain to a large proportion unavailable for the food web (Bouchard and Lefeuvre 2000; Melillo et al. 1982). Although we did not measure productivity and thus no carbon and nitrogen turnover rates, we found that the high above-ground productivity of monospecific stands of E. atherica is accompanied by reduced below-ground biomass and stocks of carbon and nitrogen. These effects on carbon and nutrient cycles may be considered in the management of saltmarsh sites besides the decrease in biodiversity in ungrazed E. atherica communities. Extensive grazing can lead to control of the invasive spread of competitive species, opening up space for other plant species (Ford et al. 2012; Loucougaray et al. 2004), and leading to increased soil carbon and nitrogen pools, for example. 


\section{Root morphological traits}

Contradicting our expectations, there were no clear patterns of root morphological traits across the salt marsh species. While specific root length and specific root area were higher and root tissue density was lower at the Spiekeroog site, which enables plants a better access to nutrients with low investigations in structural carbon in the sandy site with lower nutrient availability (Fig. 3.5), there was neither a distinct trend in the communities across the saltmarsh flooding gradients (chapter 3) nor in the seedlings from the greenhouse experiment (chapter 2). We had expected to find lower specific root area and specific root length, but higher root tissue density in the more stress-tolerant species of the frequently inundated pioneer zone than in the more competitive species in the upper saltmarsh zone (Bouma et al. 2002). In contrary, specific root length and specific root area were higher and root tissue density was lower in seedlings of $S$. europaea than in A. portulacoides and $E$. atherica in the greenhouse experiment (Fig. 2.4), which we attributed to the fact that S. europaea is an annual species. Also Bouma et al. (2002) found an only weak relationship between the root morphology of three saltmarsh grass species to nitrogen supply, inundation and oxygen content of the sediment. We conclude that root morphological traits in salt marshes are rather a result of speciesspecific adaptations of the roots, for example the formation of aerenchyma, or differences between annual and perennial species than being subject to a general pattern caused by the stress- and competition-gradient in the salt marsh. Further species-specific morphological investigations of roots would provide insight into the causes for these trait patterns. Moreover, root morphology did not appear to show plasticity in dependence of environmental conditions, at least at the seedling stage, i.e. root morphology in seedlings did not differ depending on the soil waterlogging treatment (Fig. 2.4).

\section{Plant water use}

A clear relationship to the zonation of species across the saltmarsh flooding gradient was found in the species-specific contribution of saline water to plant water use (chapter 4). The proportion of use of saline water decreased with increasing distance of plant species occurrence from the sea; Spartina anglica was able to use up to $98 \%$ of saline water, whereas A. portulacoides utilized $61-95 \%$ of seawater and E. atherica took up only $25-39 \%$ of seawater (Fig. 4.3). These measurements reflect the tolerance towards salinity of the given species: while $S$. anglica has a very efficient mechanism for excreting up to $60 \%$ of absorbed sodium ions and $A$. portulacoides copes with salinity by accumulating proline and methylated quaternary ammonium compounds for osmotic adjustment, the 
growth rate of E. atherica is strongly reduced under seawater flooding (Rozema et al. 1985; Rozema et al. 1981; Redelstein et al. 2018).

Integrating our data from chapters 3 and 4, there was a significant positive relationship between the contribution of a soil depth to plant water uptake and the proportion of fine roots in the respective soil depth (Fig. 4.5). The top soil with highest fine root mass contributed most to plant water whereas both fine root mass and water contribution decreased in deeper soil (Figs 3.3, 4.4, 4.5). However, contradicting our expectations, a reduction of physiological activity (i.e. less water uptake per fine root mass) in deeper soil layers could not be found. In contrary, the ratio of water uptake/fine root mass was even higher (although not significant) in the deeper soil $(20-30 \mathrm{~cm})$ than that of the topsoil (Fig. 4.5). We had hypothesized that physiological activity of fine roots would decrease towards deeper sediment due to potentially toxic compounds in the anoxic subsoil. Our findings, however, underline the good adaptation of plant roots to soil anoxia and toxicity in deeper soil layers. These adaptations include for example the formation of aerenchymatic tissue in the roots to provide the root and rhizosphere with oxygen and to oxidize toxic compounds, such as sulfide, in the anoxic sediment.

\subsection{Saltmarsh plant reactions to changing flooding frequencies}

As described in the general introduction, several studies postulate a threat of salt marshes due to rising sea level (Schile et al. 2014; Kirwan et al. 2010; van Wijnen and Bakker 2001). With the setup of experimental islands within the BEFmate project, reactions of saltmarsh communities to changes in flooding frequencies were investigated. These included more frequent flooding on the lower levels of the experimental islands, as for example under rising sea level, as well as less frequent flooding on the upper levels, creating a more competition based habitat.

The study on source water use of saltmarsh plants on the experimental islands (chapter 4) indicated that species have the potential to adapt to increases of saline water in their water sources. This could be demonstrated by the example of the species A. portulacoides, dominant in the lower saltmarsh community of our study sites, which was able to utilize increased proportions of saline water under more frequent inundation on the pioneer zone level of the experimental islands (Fig. 4.3). In our study, it was shown that this species is able to take up seawater in similar proportions as S. anglica at comparable inundation frequencies and thus, cope with increasing saline water sources up to a certain level. However, it remains unclear whether there is a threshold for the use of saline water in $A$. portulacoides meaning that at a certain level of sea level rise this species will possibly not be able to cope with the increasing saline water sources anymore. Investigations on other species to understand whether they are also able to adapt their water sources to rising sea levels would be of high interest. 
Although A. portulacoides was able to take up increased proportions of saline water under increasing flooding frequency, a rapid dying of the species was observed on the pioneer zone level of the experimental islands and, even more, on transplanted plots within the natural salt marsh due to increased flooding (Balke et al. 2017). Uptake of saline water is only one of several physiological stress factors plants need to cope with under rising sea levels such as increased waterlogging and anoxia in the sediment, increased concentrations of toxic compounds and increased exposure to wind and wave forces. All of these factors may have contributed to the dying of A. portulacoides transplanted to the pioneer zone level of the experimental islands and within the salt marsh despite its ability to cope with increasing salinity.

Besides reactions to stress by more frequent inundation, also community changes due to competition were assessed, especially on the upper levels of the experimental islands. It was hypothesized that changes in the transplanted communities due to competition can take considerably more time than those due to stress (Helm et al. 2006; Lindborg and Eriksson 2004; Balke et al. 2017). This hypothesis was confirmed as during the first year of vegetation observation on the experimental islands E. atherica and S. anglica had not yet colonized sods transplanted to the upper salt marsh or the pioneer zone, respectively, in high abundances likely leading to a competitive exclusion of lower saltmarsh species (Balke et al. 2017).

We also investigated fine root mass and nutrient dynamics on the three levels of the experimental islands (manuscript in preparation, Dinter et al.). We had expected to find slower changes in fine root mass of the sods transplanted to the competition-based upper saltmarsh levels and rapid changes in the stress-induced pioneer zone levels but no changes in the lower saltmarsh levels as abiotic conditions were similar compared to the original habitat. In contrast, there was a strong decrease in fine root mass on all three levels of the experimental islands already 6 weeks after transplantation. We attributed this to a stress-induced response of plants to transplantation without full recovery within the first year. However, in the long-term measurement (1 year) there was an increase in fine root mass compared to the short-term sampling time-point (6 weeks) on the lower saltmarsh level of the experimental islands whereas in both other levels there was a further decrease in fine root mass. This gives a first indication of recovery in the lower salt marsh with adequate abiotic conditions, but the long-term future developments of the experiment remain of great interest for further conclusions on the development of plant biomass under stress-based and competition-based conditions. With this study the existence of effects of different inundation frequencies on soil development and fine root responses could be confirmed. Especially soil parameters partially showed rapid directed changes: proxies for a marine environment (element concentrations of $\mathrm{Na}, \mathrm{P}$ ) showed an initially strong increase on the upper saltmarsh levels compared to the natural upper salt marsh. Concentrations then 
decreased on the saltmarsh enclosed plots while levels increased further on the experimental islands. This is in accordance with the general trend of a faster approximation to the expected conditions on the salt marsh enclosed plots compared to the more isolated experimental islands with higher exposure to marine influences (Balke et al. 2017). From this study, we conclude that one year after transplantation of sods to the experimental islands, there were strong effects on soil and root traits. However, on the abiotic level directed changes occurred first, while plants mainly showed a stressinduced response to transplanting. Long-term monitoring on the experimental islands would allow testing our initial hypotheses that soil and root traits will change over time to their original state in the respective saltmarsh zone and that these changes occur faster in the stress-based system than in the competition-based system.

Overall, Balke et al. (2017) evaluated the setup of the experimental islands as a suitable model system for in situ metacommunity experiments. Further investigations over longer periods of time will give deeper insights into saltmarsh community assembly and disassembly and reactions to changing sea levels.

\subsection{Conclusions}

Linking our three studies, it can be pointed out that saltmarsh plants have developed various speciesspecific adaptations of their below-ground organs to enable their survival under the harsh environmental conditions of salt marshes. These adaptive root traits are likely already developed in newly establishing seedlings as there were species-specific differences and responses to environmental stress already at the seedling stage (chapter 2). Interspecific differences particularly corresponded to the gradient of inundation frequency and associated salinity, waterlogging and mechanical disturbance in all three studies which supports several previous studies. The zonation of plant species has often been related to abiotic factors and with our studies we could further disentangle some of the factors forming saltmarsh community structure. With this, we can contribute to the understanding of ecological processes influencing the development of saltmarsh zonation as well as their sensitivity to environmental change, i.e. during climate change or land use change. Based on the hypotheses formulated in the beginning of the present thesis, the following results were found:

(i) Especially rapid root growth contributes to the stability of newly establishing seedlings exposed to sediment erosion on tidal flats; this is in turn affected by species-specific responses to waterlogged soil. 
In our greenhouse experiment the upper saltmarsh species $E$. atherica grew fastest under drained conditions and showed highest resistance towards the erosion treatments but suffered strongest under waterlogged soil conditions. This underlined the role of waterlogged soil conditions as one potential driver for the distribution of species across the saltmarsh gradient, and the competitive strength of $E$. atherica under drained sediment conditions. It was especially highlighted that seedlings from pioneer species establishing in vegetated coastal ecosystems, such as salt marshes or also mangroves, need rapid root growth to utilize a disturbance free Window of Opportunity to gain stability and to survive wave forces and sediment erosion.

(ii) Saltmarsh species are able to develop an extensive fine root system despite the waterlogged and saline conditions in their habitat. There is a positive effect of biodiversity on fine root biomass across the saltmarsh communities.

Saltmarsh species appear to be well adapted to the abiotic conditions in their habitat which require high investments in below-ground biomass. Certain species are also well adapted to the anoxic deeper soil layers maintaining high fine root densities with high physiological activity (in particular regarding water uptake) over the soil profile. The most important determinant for fine root biomass was species diversity indicating root space partitioning in species rich communities. Below-ground biomass and thus, also carbon and nitrogen pools were reduced in the monospecific stands of $E$. atherica. This reveals that maintaining diverse saltmarsh sites is essential to preserve their important ecosystem services.

(iii) The tolerance of saltmarsh plants towards salinity and their habitat within the salt marsh are reflected by their water uptake behavior. Certain species may show a flexible water use strategy under changing inundation regimes making them well adapted to sea level rise.

There was a gradient in the use of water sources with a decreasing use of sea water by species inhabiting saltmarsh zones further away from the seaward edge. On the experimental islands $A$. portulacoides, a dominant species in the ungrazed lower salt marsh, showed a good adaptation of its water use to rising sea levels under climate change. Although able to use a wide range of water sources, A. portulacoides died on the lower levels of the experimental islands, indicating that not salinity of source water but other abiotic factors may lead to extinction of this species under rising sea level from its original habitat. However, depending on the model used for the prediction of sea level rise, salt marshes may be able to grow at same rates as sea level rises (Kirwan et al. 2016) and are 
thus not directly threatened by drowning. Nevertheless, long-term observations of species composition and abiotic factors on the experimental islands will provide further important results for the prediction of saltmarsh community development and interactions with changing abiotic conditions.

\section{References}

Bachmann D, Gockele A, Ravenek JM, Roscher C, Strecker T, Weigelt A, Buchmann N (2015) No evidence of complementary water use along a plant species richness gradient in temperate experimental grasslands. PloS one 10:e0116367. doi:10.1371/journal.pone.0116367.

Balke T, Bouma TJ, Horstman EM, Webb EL, Erftemeijer PL, Herman PM (2011) Windows of opportunity: thresholds to mangrove seedling establishment on tidal flats. Marine Ecology Progress Series 440:1-9. doi:10.3354/meps09364.

Balke T, Lõhmus K, Hillebrand H, Zielinski O, Haynert K, Meier D, Hodapp D, Minden V, Kleyer M (2017) Experimental salt marsh islands: A model system for novel metacommunity experiments. Estuarine, Coastal and Shelf Science 198:288-298. doi:10.1016/j.ecss.2017.09.021.

Balke T, Webb EL, van den Elzen E, Galli D, Herman PMJ, Bouma TJ (2013) Seedling establishment in a dynamic sedimentary environment: a conceptual framework using mangroves. The Journal of Applied Ecology 50:740-747. doi:10.1111/1365-2664.12067.

Bloom AJ, Chapin FS, Mooney HA (1985) Resource limitation in plants - an economic analogy. Annual Review of Ecology and Systematics 16:363-392.

Bouchard V, Lefeuvre JC (2000) Primary production and macro-detritus dynamics in a European salt marsh: carbon and nitrogen budgets. Aquatic Botany 67:23-42.

Bouma TJ, Hengst K, Koutstaal BP, van Soelen J (2002) Estimating root lifespan of two grasses at contrasting elevation in a salt marsh by applying vitality staining on roots from in-growth cores. Plant Ecology 165:235-245.

Cardinale BJ, Srivastava DS, Duffy JE, Wright JP, Downing AL, Sankaran M, Jouseau C (2006) Effects of biodiversity on the functioning of trophic groups and ecosystems. Nature 443:989-992. doi:10.1038/nature05202.

Chen Y, Thompson CEL, Collins MB (2012) Saltmarsh creek bank stability: Biostabilisation and consolidation with depth. Continental Shelf Research 35:64-74. doi:10.1016/j.csr.2011.12.009.

Connell JH (1978) Diversity in tropical rain forests and coral reefs. Science (New York) 199:13021310. doi:10.1126/science.199.4335.1302.

Cooper A (1982) The effects of salinity and waterlogging on the growth and cation uptake of salt marsh plants. New Phytologist 90:263-275. 
Coops H, Geilen N, Verheij HJ, Boeters R, van der Velde G (1996) Interactions between waves, bank erosion and emergent vegetation: An experimental study in a wave tank. Aquatic Botany 53:187198.

Dinter T, Redelstein R, Leuschner C, Kuzyakov Y Nutrient and fine root patterns during soil development within salt marsh ecosystems and on artificial islands. in preparation.

Dodd MB, Lauenroth WK, Welker JM (1998) Differential water resource use by herbaceous and woody plant life-forms in a shortgrass steppe community. Oecologia 117:504-512.

Ford H, Garbutt A, Jones DL, Jones L (2012) Impacts of grazing abandonment on ecosystem service provision: Coastal grassland as a model system. Agriculture Ecosystems \& Environment 162:108115. doi:10.1016/j.agee.2012.09.003.

Ford H, Garbutt A, Ladd C, Malarkey J, Skov MW (2016) Soil stabilization linked to plant diversity and environmental context in coastal wetlands. Journal of Vegetation Science 27:259-268. doi:10.1111/jvs.12367.

Gould IJ, Quinton JN, Weigelt A, Deyn GB de, Bardgett RD, Seabloom E (2016) Plant diversity and root traits benefit physical properties key to soil function in grasslands. Ecology letters 19:11401149. doi:10.1111/ele.12652.

Grime JP (1973) Competitive exclusion in herbaceous vegetation. Nature 242:344-347.

Groenendijk AM, Vinklievaart MA (1987) Primary production and biomass on a Dutch salt-marsh emphasis on the belowground component. Vegetatio 70:21-27.

He Q, Altieri AH, Cui B (2015) Herbivory drives zonation of stress-tolerant marsh plants. Ecology 96:1318-1328. doi:10.1890/14-0937.1.

Hector A, Hautier Y, Saner P, Wacker L, Bagchi R, Joshi J, Scherer-Lorenzen M, Spehn EM, Bazeley-White E, Weilenmann M, Caldeira MC, Dimitrakopoulos PG, Finn JA, Huss-Danell K, Jumpponen A, Mulder CPH, Palmborg C, Pereira JS, Siamantziouras ASD, Terry AC, Troumbis AY, Schmid B, Loreau M (2010) General stabilizing effects of plant diversity on grassland productivity through population asynchrony and overyielding. Ecology 91:2213-2220.

Helm A, Hanski I, Partel M (2006) Slow response of plant species richness to habitat loss and fragmentation. Ecology letters 9:72-77. doi:10.1111/j.1461-0248.2005.00841.x.

Hooper DU, Chapin FS, Ewel JJ, Hector A, Inchausti P, Lavorel S, Lawton JH, Lodge DM, Loreau M, Naeem S, Schmid B, Setala H, Symstad AJ, Vandermeer J, Wardle DA (2005) Effects of biodiversity on ecosystem functioning: A consensus of current knowledge. Ecological Monographs 75:3-35.

Hu L-J, Li P, Guo Q (2013) Positive plant diversity-soil stability relationships are mediated through roots in the Songnen grassland: chronosequence evidence. Notulae Botanicae Horti Agrobotanici Cluj-Napoca 41:626-637.

Huckle JM, Potter JA, Marrs RH (2000) Influence of environmental factors on the growth and interactions between salt marsh plants: effects of salinity, sediment and waterlogging. Journal of Ecology 88:492-505. 
Jackson RB, Mooney HA, Schulze E-D (1997) A global budget for fine root biomass, surface area, and nutrient contents. Proceedings of the National Academy of Sciences 94:7362-7366. doi:10.1073/pnas.94.14.7362.

Katschnig D, Broekman R, Rozema J (2013) Salt tolerance in the halophyte Salicornia dolichostachya Moss: Growth, morphology and physiology. Environmental and Experimental Botany 92:32-42. doi:10.1016/j.envexpbot.2012.04.002.

Kirwan ML, Guntenspergen GR, D'Alpaos A, Morris JT, Mudd SM, Temmerman S (2010) Limits on the adaptability of coastal marshes to rising sea level. Geophysical Research Letters 37:L23401. doi:10.1029/2010GL045489.

Kirwan ML, Temmerman S, Skeehan EE, Guntenspergen GR, Fagherazzi S (2016) Overestimation of marsh vulnerability to sea level rise. Nature Climate Change 6:253-260. doi:10.1038/NCLIMATE2909.

Kulmatiski A, Beard KH, Verweij RJT, February EC (2010) A depth-controlled tracer technique measures vertical, horizontal and temporal patterns of water use by trees and grasses in a subtropical savanna. New Phytologist 188:199-209. doi:10.1111/j.1469-8137.2010.03338.x.

Lindborg R, Eriksson O (2004) Historical landscape connectivity affects present plant species diversity. Ecology 85:1840-1845.

Loreau M, Hector A (2001) Partitioning selection and complementarity in biodiversity experiments. Nature 412:72-76. doi:10.1038/35083573.

Loucougaray G, Bonis A, Bouzille JB (2004) Effects of grazing by horses and/or cattle on the diversity of coastal grasslands in western France. Biological Conservation 116:59-71. doi:10.1016/S0006-3207(03)00177-0.

Melillo JM, Aber JD, Muratore JF (1982) Nitrogen and lignin control of hardwood leaf litter decomposition dynamics. Ecology 63:621-626.

Moreno-Gutierrez C, Dawson TE, Nicolas E, Ignacio Querejeta J (2012) Isotopes reveal contrasting water use strategies among coexisting plant species in a Mediterranean ecosystem. New Phytologist 196:489-496. doi:10.1111/j.1469-8137.2012.04276.x.

Mossman HL, Brown MJH, Davy AJ, Grant A (2012) Constraints on salt marsh development following managed coastal realignment: dispersal limitation or environmental tolerance? Restoration Ecology 20:65-75. doi:10.1111/j.1526-100X.2010.00745.x.

Nippert JB, Knapp AK (2007) Soil water partitioning contributes to species coexistence in tallgrass prairie. Oikos 116:1017-1029. doi:10.1111/j.2007.0030-1299.15630.x.

Pohl M, Alig D, Körner C, Rixen C (2009) Higher plant diversity enhances soil stability in disturbed alpine ecosystems. Plant and Soil:91-102.

Rand TA (2000) Seed dispersal, habitat suitability and the distribution of halophytes across a salt marsh tidal gradient. Journal of Ecology 88:608-621. doi:10.1046/j.1365-2745.2000.00484.x.

Redelstein R, Zotz G, Balke T (2018) Seedling stability in waterlogged sediments. An experiment with saltmarsh plants. Marine Ecology Progress Series 590:95-108. doi:10.3354/meps 12463. 
Redondo-Gómez S, Mateos-Naranjo E, Davy AJ, Fernandez-Munoz F, Castellanos EM, Luque T, Figueroa ME (2007) Growth and photosynthetic responses to salinity of the salt-marsh shrub Atriplex portulacoides. Annals of Botany 100:555-563. doi:10.1093/aob/mcm119.

Rose L, Hertel D, Leuschner C (2012) Livestock-type effects on biomass and nitrogen partitioning in temperate pastures with different functional-group abundance. Grass and Forage Science 68:386394.

Rozema J, Bijwaard P, Prast G, Broekman R (1985) Ecophysiological adaptations of coastal halophytes from foredunes and salt marshes. Vegetatio 62:499-521.

Rozema J, Gude H, Pollak G (1981) An ecophysiological study of the salt secretion of 4 halophytes. New Phytologist 89:201-217.

Rozema J, van Diggelen J (1991) A comparative study of growth and photosynthesis of 4 halophytes in response to salinity. Acta Oecologica-International Journal of Ecology 12:673-681.

Schile LM, Callaway JC, Morris JT, Stralberg D, Parker VT, Kelly M (2014) Modeling tidal marsh distribution with sea-level rise: evaluating the role of vegetation, sediment, and upland habitat in marsh resiliency. PloS one 9. doi:10.1371/journal.pone.0088760.

Schwendenmann L, Veldkamp E, Moser G, Hölscher D, Köhler M, Clough Y, Anas I, Djajakirana G, Erasmi S, Hertel D, Leitner D, Leuschner C, Michalzik B, Propastin P, Tjoa A, Tscharntke T, van Straaten O (2010) Effects of an experimental drought on the functioning of a cacao agroforestry system, Sulawesi, Indonesia. Global Change Biology 16:1515-1530. doi:10.1111/j.13652486.2009.02034.x.

Smith KK, Good RE, Good NF (1979) Production dynamics for above and belowground components of a New Jersey Spartina alterniflora tidal marsh. Estuarine and Coastal Marine Science 9:189201.

Steudel B, Hautier Y, Hector A, Kessler M (2011) Diverse marsh plant communities are more consistently productive across a range of different environmental conditions through functional complementarity. Journal of Applied Ecology 48:1117-1124. doi:10.1111/j.13652664.2011.01986.x.

Sullivan G, Callaway JC, Zedler JB (2007) Plant assemblage composition explains and predicts how biodiversity affects salt marsh functioning. Ecological Monographs 77:569-590. doi:10.1890/061947.1.

Tripathee R, Schaefer KVR (2015) Above- and belowground biomass allocation in four dominant salt marsh species of the eastern United States. Wetlands 35:21-30. doi:10.1007/s13157-014-0589-z.

Valery L, Bouchard V, Lefeuvre JC (2004) Impact of the invasive native species Elymus athericus on carbon pools in a salt marsh. Wetlands 24:268-276.

van Wijnen HJ, Bakker JP (2001) Long-term surface elevation change in salt marshes: a prediction of marsh response to future sea-level rise. Estuarine, Coastal and Shelf Science 52:381-390. doi:10.1006/ecss.2000.0744. 
West AG, Dawson TE, February EC, Midgley GF, Bond WJ, Aston TL (2012) Diverse functional responses to drought in a Mediterranean-type shrubland in South Africa. New Phytologist 195:396-407. doi:10.1111/j.1469-8137.2012.04170.x.

Windham L, Weis JS, Weis P (2003) Uptake and distribution of metals in two dominant salt marsh macrophytes, Spartina alterniflora (cordgrass) and Phragmites australis (common reed). Estuarine, Coastal and Shelf Science 56:63-72. doi:10.1016/S0272-7714(02)00121-X.

Wolters M, Garbutt A, Bakker JP (2005) Plant colonization after managed realignment: the relative importance of diaspore dispersal. Journal of Applied Ecology 42:770-777. doi:10.1111/j.13652664.2005.01051.x. 
APPENDIX

\section{Cryogenic vacuum extraction and stable isotope analysis}




\section{A.1 Set up of the cryogenic vacuum extraction line}

In our study on plant water uptake patterns (Redelstein et al. 2018, chapter 4) xylem water from root crowns and soil water was extracted by cryogenic water extraction (Ingraham and Shadel 1992; Dalton 1988; Dawson and Ehleringer 1993) to determine the composition of stable water isotopes $\left({ }^{18} \mathrm{O}\right.$ and $\left.{ }^{2} \mathrm{H}\right)$ of the plants and soil. For this purpose a new cryogenic vacuum extraction line was set up in the laboratory at the Plant Ecology and Ecosystems Research department in Göttingen. During cryogenic vacuum extraction of plant and soil material, the sample is heated under vacuum conditions. Water evaporates from the soil or plant material and is trapped by freezing in a cold trap filled with liquid nitrogen. After thawing, the sample is accessible for analysis of stable isotopes.

The cryogenic extraction line was set up according to Orlowski et al. (2013) with modifications following Koeniger et al. (2011). The setup of the cryogenic extraction line is given in Figures A1.1 and A1.2. The extraction line consists of 4 independent extraction units with 5 extraction tubes each (Figure A1.2a). Extraction tubes are heat-resistant and vacuum-tight glass tubes with a V-shaped end connected to a vacuum system by a valve. On the other end, extraction tubes are connected to the sampling tubes. These are either glass tubes connected to the V-tubes by rubber seals and clips (Figure A1.2b) or gas tight exetainers connected to the extraction tubes by piercing the septum of the vials with a cannula (diameter $1.2 \mathrm{~mm}$; Figure A1.2c and d). Samples are frozen in liquid nitrogen prior to their connection to the extraction system and heated to $80^{\circ} \mathrm{C}$ by means of a water bath after connection to the vacuum system. The system is evacuated to approx. $10^{0}-10^{-1} \mathrm{mbar}$ by a vacuum pump (Rotary vane pump RZ 2.5, vacuubrand, Wertheim, Germany) and pressure is monitored by a vacuum gauge (DCP 3000 with Pressure transducer VSP 3000, vacuubrand, Wertheim, Germany). Every extraction unit can be monitored separately and connected and disconnected individually from the vacuum pump.

During the extraction process, heating of the samples leads to evaporation of the water bound to the soil or plant sample into the extraction tubes where it condenses and gets trapped in the V-tubes submerged in liquid nitrogen. Samples were extracted for two hours. After extraction, the vacuum system is aerated by $\mathrm{N}_{2}$ gas to avoid entering air moisture into the system. Extracted water is thawed and pipetted to $2 \mathrm{ml}$ glass vials and stored cool until stable isotope analysis. To determinate the extraction efficiency (i.e. the proportion of water extracted from the sample), extraction tubes are weighed immediately after extraction and once more after drying for $48 \mathrm{~h}$ at $120{ }^{\circ} \mathrm{C}$ to determine the fraction of water which was not removed by extraction. 


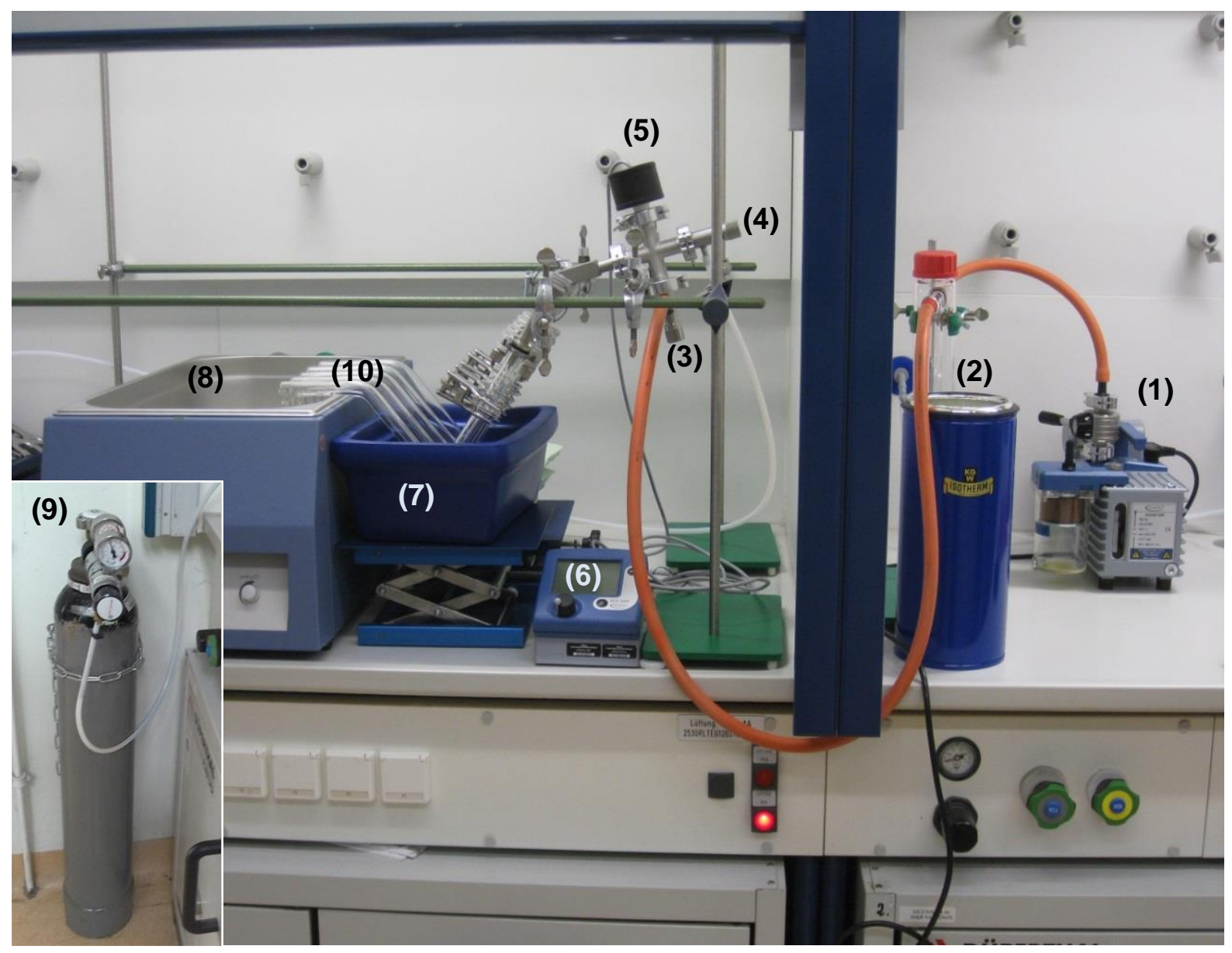

Figure A1.1: Set up of the cryogenic-vacuum extraction line
(1) Vacuum pump
(2) Liquid nitrogen trap for preventing water from entering the pump
(3) Vacuum valve
(4) Valve for purging the system with $\mathrm{N}_{2}$
(5) Pressure transducer
(6) Vacuum gauge
(7) Thermobox for liquid nitrogen
(8) Water bath
(9) Nitrogen cylinder with pressure reducer
(10) Extraction units (close up below) 

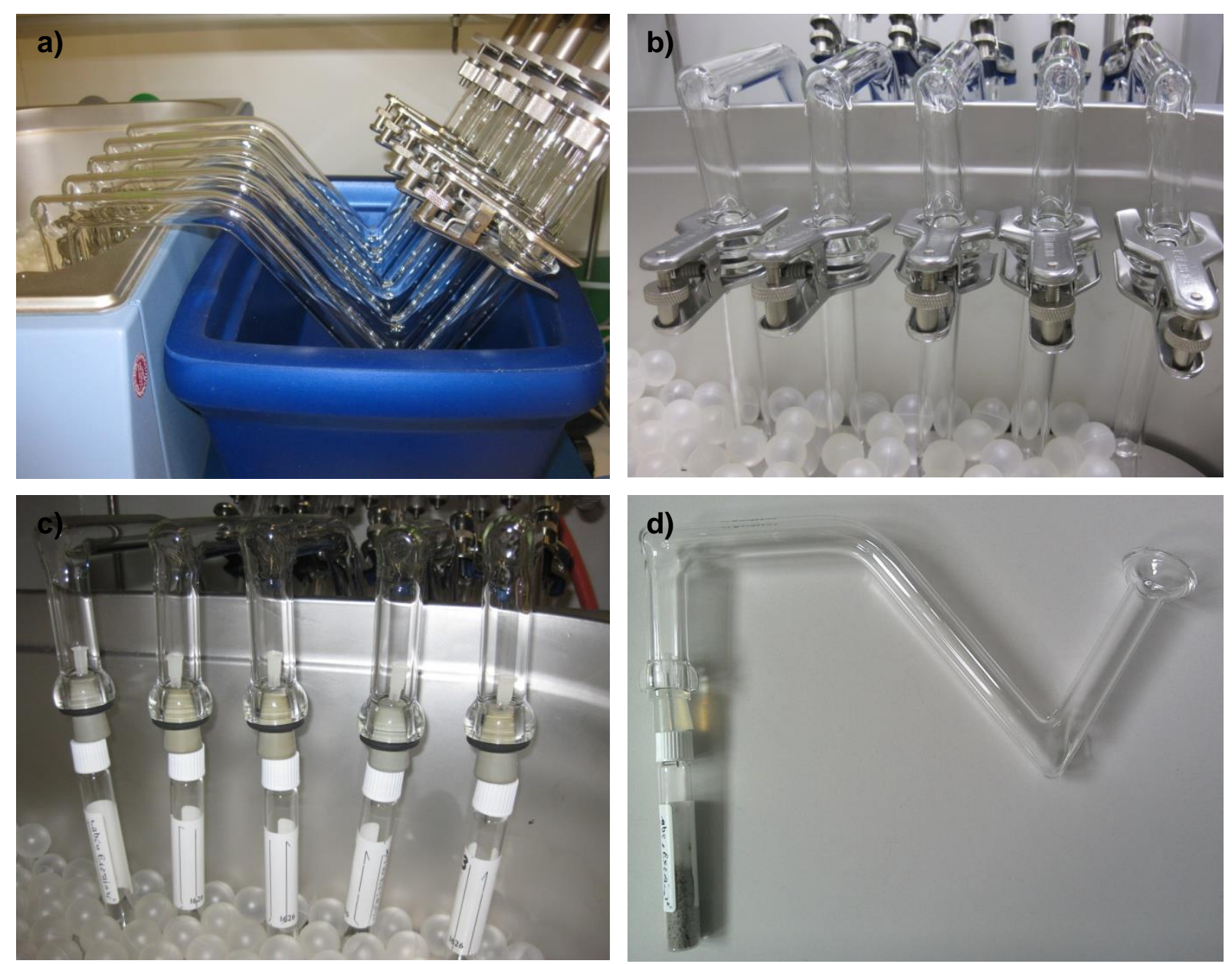

Figure A1.2: a) Close up of an extraction unit: V-shaped extraction tubes placed in a thermobox for liquid nitrogen where the extracted water is trapped. b-d) Connection of the sample tubes to the V-tubes. In b) samples are filled into glass tubes which are connected to the extraction system by rubber seals and clips ('Method 1'). c and d): For direct extraction from Labco® sampling vials, the V-tubes are closed with a stopper pierced by a cannula. The septum of the vials is then pierced by the cannula and thus, connected to the extraction system ('Method 2'). 


\section{A.2 Validation of the extraction system}

After set up of the extraction line, different tests were performed to validate the efficiency and reproducibility of the extraction system.

\section{Water-water-extraction}

In a first test, three types of water with different isotopic compositions were extracted and isotopic signature of the extracted water was compared to that of the unextracted water ('water-waterextraction'). This test was performed for both versions of the extraction setup (extraction from glass tubes connected to the vacuum system with clips, 'method 1'; or extraction directly from labco sampling vials pierced by a cannula to connect the vial to the extraction system, 'method 2'). For method 1, an additional 'cross-contamination test' was performed where water types of different isotopic composition were extracted in parallel from the same extraction unit. This test was supposed to ensure that no contamination from one sample to another occurs through the extraction system. Differences of the mean values for $\delta^{18} \mathrm{O}$ and $\delta^{2} \mathrm{H}$ between the extracted and unextracted water were in most cases within a threshold of $\pm 0.2 \%$ and $\pm 1.5 \%$, respectively (Fig. A2.1). This threshold for acceptable performance of $\delta^{18} \mathrm{O}$ and $\delta^{2} \mathrm{H}$ measurements has been set by the International Atomic Energy Agency (IAEA) and has been considered reasonable for different hydrologic studies. The only exception was the $\delta^{18} \mathrm{O}$-value for the cross-contamination test in water type A extracted with method 1 (difference $0.38 \%$ ).

A second water-water-extraction was performed for direct comparison of both extraction methods. The same two water types were extracted with both methods and isotopic composition was measured. Differences of the mean values for $\delta^{18} \mathrm{O}$ and $\delta^{2} \mathrm{H}$ between the two extraction methods were always within the threshold of $\pm 0.2 \%$ and $\pm 1.5 \%$, respectively (Fig. A2.2).

After these tests we assumed to achieve reliable and reproducible results for water-water extractions from both extraction methods. 


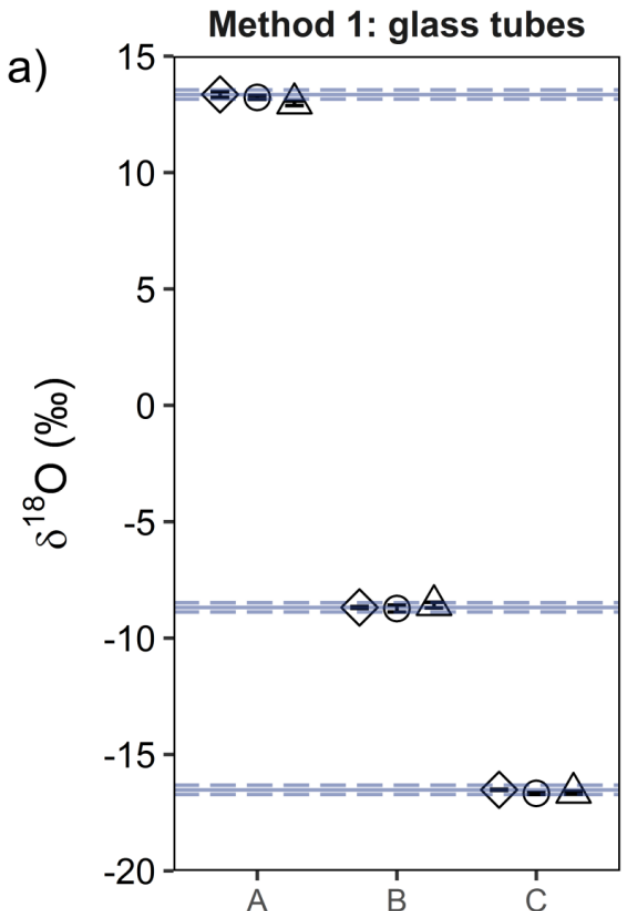

Method 2: cannula

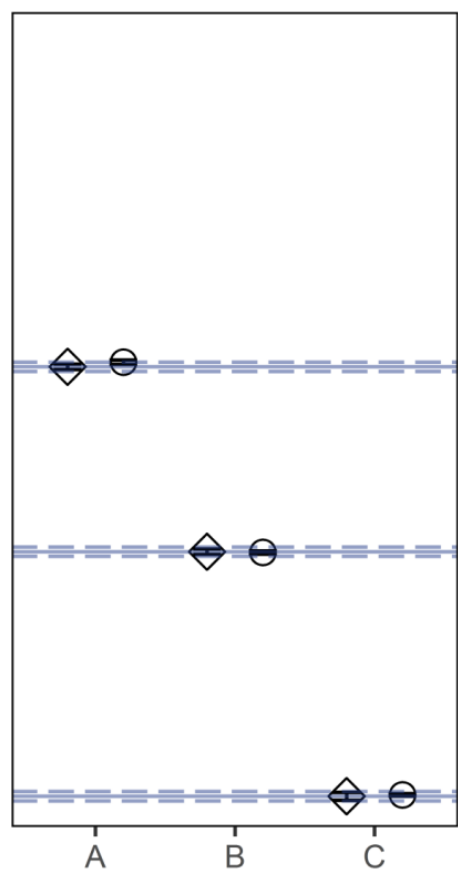
$\diamond$ unextracted water
$\bigcirc$ extracted water
$\triangle$ cross-contamination test

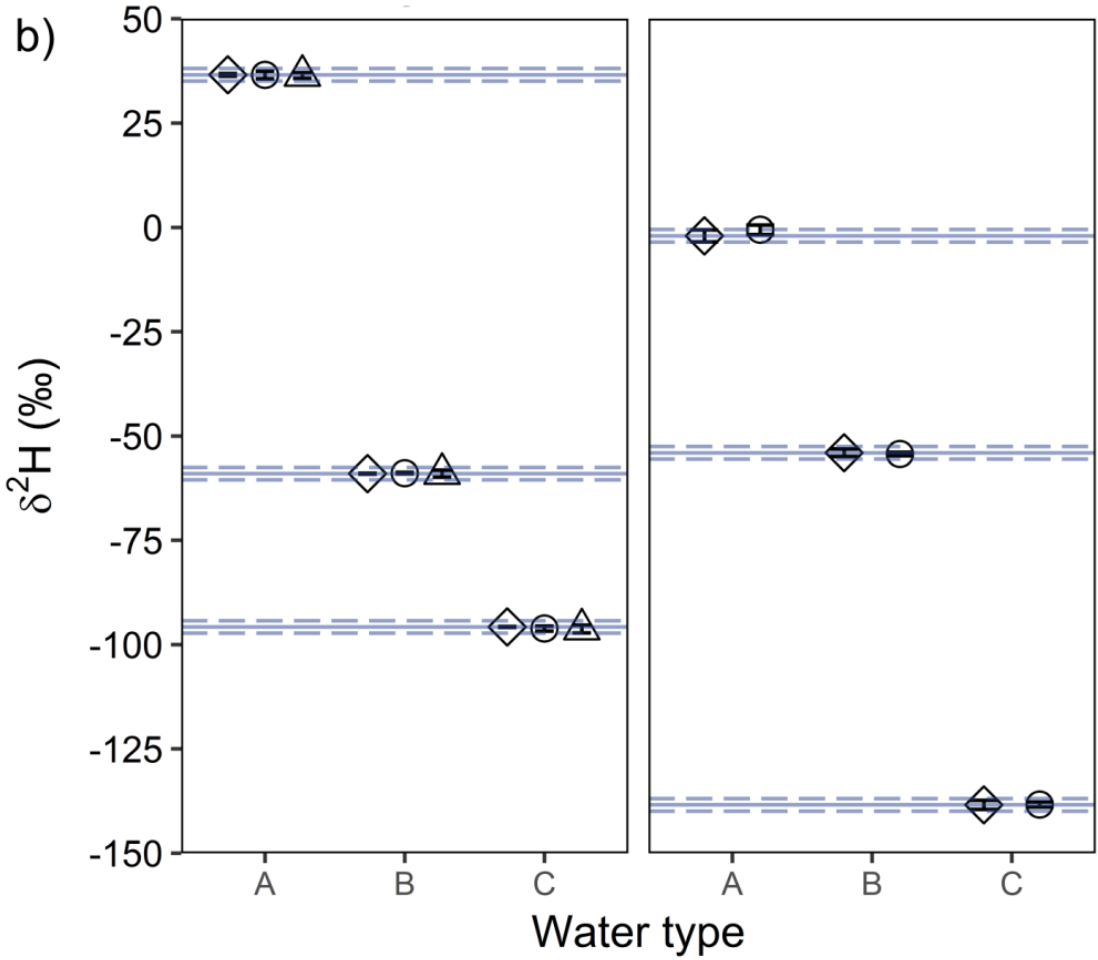

$\diamond$ unextracted water

$\bigcirc$ extracted water

$\triangle$ cross-contamination test

Figure A2.1: Results of the water-water-extraction tests for the validation of the cryogenic vacuum extraction line. $\delta^{18} \mathrm{O}$ (a) and $\delta^{2} \mathrm{H}$ (b) values were measured from three different types of water (note that water types differed between the two extraction methods) which were extracted with two different methods. Isotopic values are compared to unextracted water. Solid lines represent the value of unextracted water, dashed lines the threshold of $\pm 0.2 \%$ for $\delta^{18} \mathrm{O}$ and $\pm 1.5 \% \delta^{2} \mathrm{H}$ defined by the IAEA. 

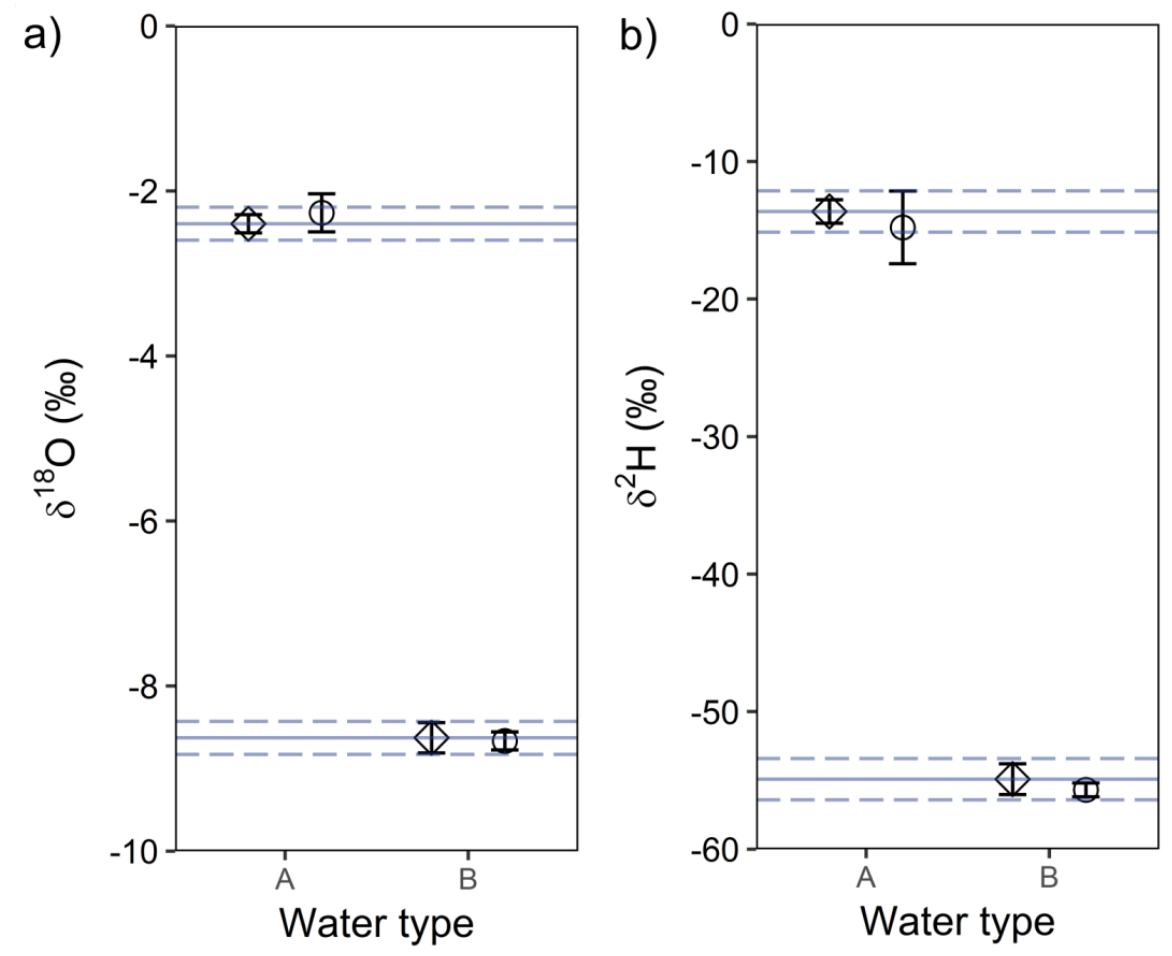

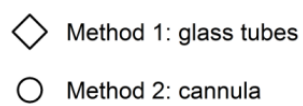

Method 2: cannula

Figure A2.2: Results of the water-water-extraction tests to compare directly between the two extraction methods. $\delta^{18} \mathrm{O}$ (a) and $\delta^{2} \mathrm{H}$ (b) values were measured from two different types of water which were extracted with both methods. Solid lines represent the value of unextracted water, dashed lines the threshold of $\pm 0.2 \%$ for $\delta^{18} \mathrm{O}$ and $\pm 1.5 \% \delta^{2} \mathrm{H}$ defined by the IAEA.

\section{Inter-laboratory comparison for extraction of soil samples}

As it is known that different soil-water interactions depending on soil-physicochemical properties may affect stable isotopic composition of extracted water (Orlowski et al. 2016; West et al. 2006; Meißner et al. 2014; Araguás-Araguás et al. 1995), we took part in an international inter-laboratory comparison of cryogenic water extraction systems to test the reliability of our extraction line for the extraction of soil samples (Orlowski et al. 2018).

Within this inter-laboratory comparison, two standard soils with different physicochemical properties (clayey loam and silty sand) were sent to 16 participating laboratories in seven countries. After drying and sieving, soils were rewetted with deionized water of known isotopic composition to create two different water contents of the soil ( $8 \%$ and $20 \%$ per weight). Soils were then extracted following two different extraction approaches: (I) our lab internal extraction conditions and (II) pre-defined extraction conditions. For the routine laboratory approach, we chose a temperature of $80{ }^{\circ} \mathrm{C}$ and an extraction time of $30 \mathrm{~min}$ for the silty sand and $40 \mathrm{~min}$ for the clayey loam, respectively, according to 
extraction times given in West et al. (2006). In the second approach, extraction conditions were predefined for all laboratories; a temperature of $100{ }^{\circ} \mathrm{C}$ was used and silty sand samples were extracted for $45 \mathrm{~min}$, whereas clayey loam was extracted for $240 \mathrm{~min}$. All extracted samples were measured for $\delta^{18} \mathrm{O}$ and $\delta^{2} \mathrm{H}$ by the Global Institute for Water Security, Saskatoon, Canada. Results from this interlaboratory comparison have been published recently in Orlowski et al. (2018).

Overall, great variations in measured $\delta^{18} \mathrm{O}$ and $\delta^{2} \mathrm{H}$-values were found between laboratories with absolute values differing partially strongly from the added reference water. Most values of extracted water samples were not within the acceptable threshold of $\pm 0.2 \%$ for $\delta^{18} \mathrm{O}$ and $\pm 1.5 \%$ for $\delta^{2} \mathrm{H}$, respectively, defined by the IAEA. However, no significant correlations of the measured isotope values with extraction conditions (temperature, time, applied vacuum) were found (Fig. A2.3), but rather soil texture and soil water content affected the isotopic composition of extracted water. With lower clay fraction and higher water content of the soil, precision of the isotope values with regard to the spiked reference water increased. This trend, as shown for our laboratory in Figure A2.4, was found in general over most laboratories. For our laboratory, the mean difference from the spiked reference water ranged from -1.97 to $1.93 \%$ for $\delta^{18} \mathrm{O}$ and from -15.8 to $-0.76 \%$ for $\delta^{2} \mathrm{H}$. Only for the silty sand samples with $20 \%$ water content most measured values were within the threshold for acceptable bias. In general we found smaller deviations from the reference water for the pre-defined extraction procedure (i.e. longer extraction times).

The results of the inter-laboratory comparison question the usefulness of cryogenic water extraction as a standard for water extraction as results were not comparable across laboratories. It was recommended to run cryogenic water extraction tests on the individual soil material used for field studies.

Therefore, we adjusted the extraction time for the extraction of our samples in our study on stable isotopes (chapter 4). By extracting a set of soil samples from our field site over different extraction times, we found a maximal extraction efficiency (> 99\%) for an extraction time of two hours. Thus, samples were extracted for two hours in order to obtain a complete water extraction and unfractionated water samples. Furthermore, all samples for our study were consistently extracted under the same conditions, so that all samples were subjected to the same potential alteration processes during the extraction procedure, and salt marsh soils extracted in our study have high water contents (30-50 \% in the clay rich upper soil and 17-24\% in the sandy lower soil), so that we assume that isotopic compositions were not altered to a considerable extent in our study. 

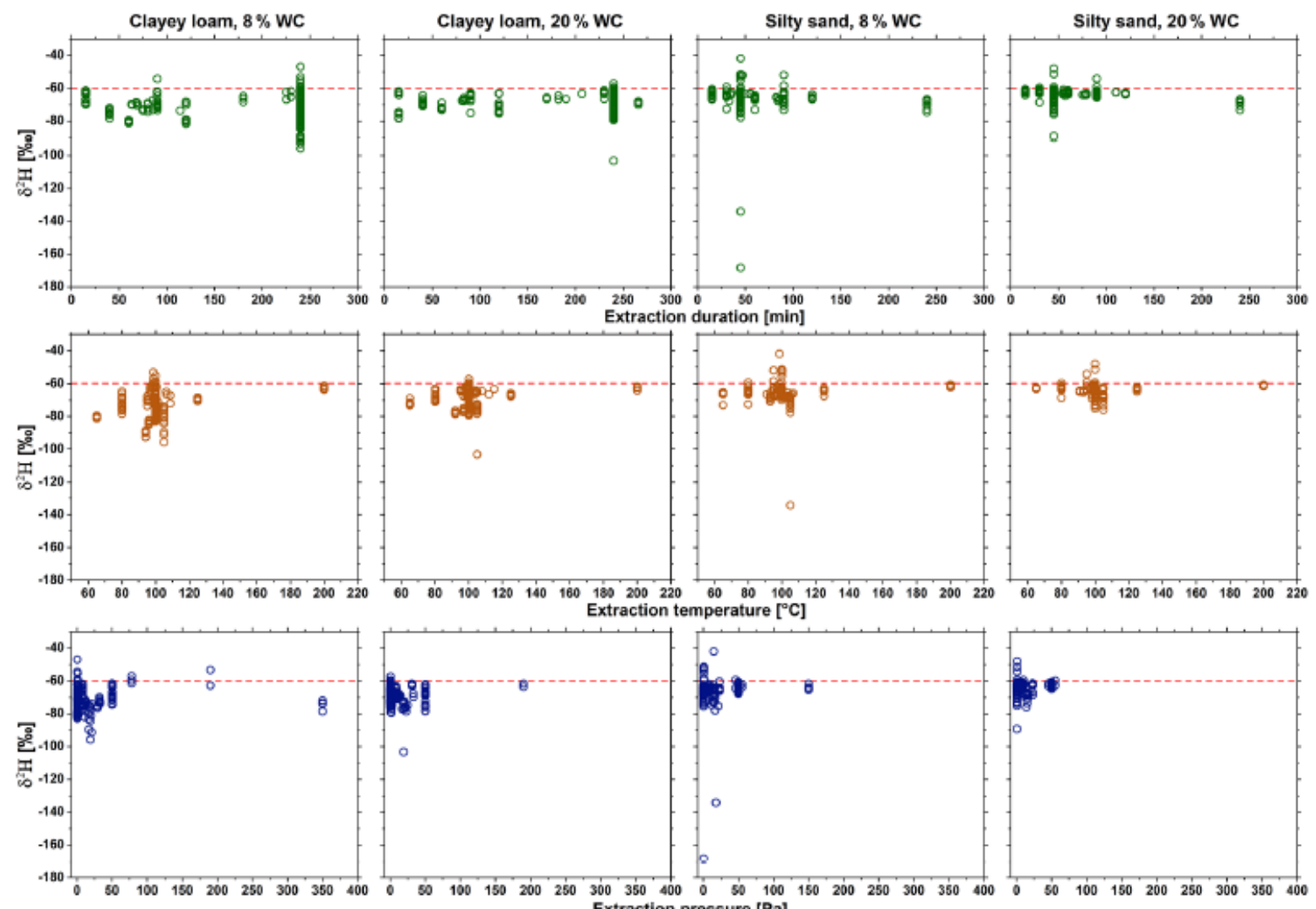

Figure A2.3: Effect of cryogenic extraction parameters (duration, temperature, and pressure) on $\delta^{2} \mathrm{H}$ results of both soil types (clayey loam and silty sand) and water contents ( 8 and $20 \%)$ shown for all labs. The mean reference DI water $\delta^{2} \mathrm{H}$ value is shown as a red dotted line (Orlowski et al. 2018). 


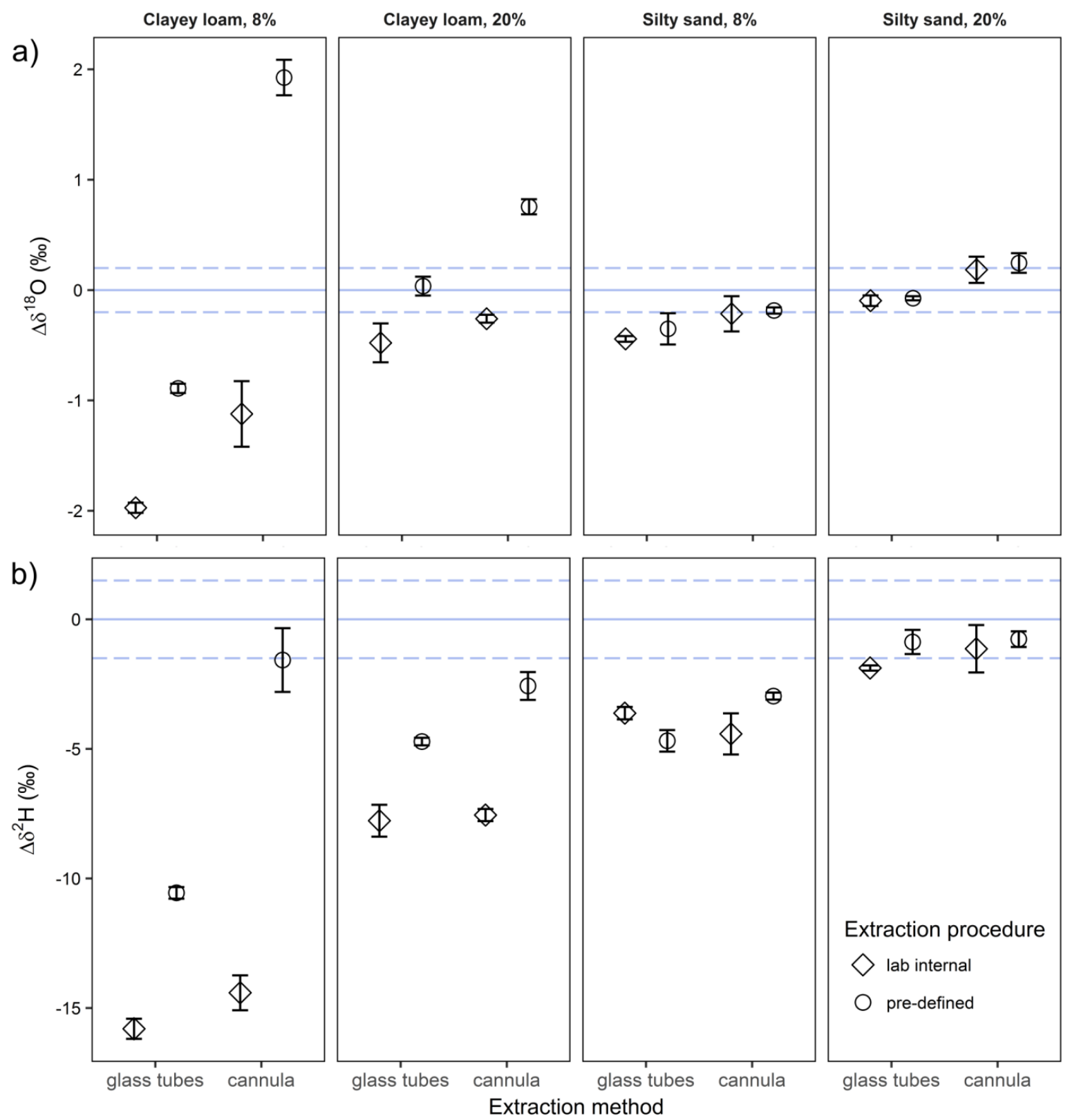

Figure A2.4: Mean differences from reference DI water $(\Delta)$ for $\delta^{18} \mathrm{O}(\mathrm{a})$ and $\delta^{2} \mathrm{H}$ (b) results of water extracts from both extraction procedures (lab internal and pre-defined), extraction methods (glass tubes and cannula), soil types (clayey loam and silty sand) and water contents (8\% and $20 \%)$. Solid lines represent a $\Delta \delta$-value of $0 \%$, dashed lines the threshold of $\pm 0.2 \%$ for $\delta^{18} \mathrm{O}$ and $\pm 1.5 \%$ o $\delta^{2} \mathrm{H}$ defined by the IAEA. 


\section{A.3 Stable isotope analysis}

In our study, stable isotopic signatures of water samples were measured by Cavity Ring-Down Spectroscopy (CRDS) on a Picarro L2120-i $\delta$ D/818O Isotopic Water Analyzer (Picarro Inc., Santa Clara, California, USA) coupled to an A0211 high-precision vaporizer.

Water Isotope Inter-Comparison 2016

With participation in the international WICO 2016 (Water Isotope Inter-Comparison) by the IAEA (International Atomic Energy Agency) we tested the performance of our Picarro device. A set of five samples (Table A3.1) of unknown isotopic signature over a broad range of values was provided by the IAEA including one sample which was contaminated with $0.05 \%$ methanol (unbeknownst to participants).

Table A3.1: Water types and assigned $\delta^{18} \mathrm{O}$ and $\delta^{2} \mathrm{H}$-values provided by the IAEA within the Water Isotope Inter-Comparison (WICO) 2016.

\begin{tabular}{llcc}
\hline \multirow{2}{*}{ Sample name } & \multicolumn{1}{c}{ Water type } & \multicolumn{2}{c}{ assigned values } \\
& \multicolumn{1}{c}{} & \multicolumn{1}{c}{$\boldsymbol{\delta}^{\mathbf{1 8}} \mathbf{O}(\mathbf{\%}) \pm \mathbf{S D}$} & $\boldsymbol{\delta}^{\mathbf{2}} \mathbf{H}(\% \mathbf{~} \mathbf{c} \pm \mathbf{S D}$ \\
\hline WICO-1 & Danube river Water, Austria, filtered & $-10.80 \pm 0.02$ & $-77.4 \pm 0.9$ \\
WICO-2 & Neusiedler See (Lake Water), Austria, filtered & $-5.11 \pm 0.03$ & $-41.7 \pm 1.1$ \\
WICO-3 & Bow River Water, Canada, filtered & $-22.01 \pm 0.05$ & $-168.3 \pm 1.0$ \\
WICO-4 & Ground Water Mix, Egypt, Austria, filtered & $-0.50 \pm 0.05$ & $+0.5 \pm 1.1$ \\
& Vienna Tap water and WICO-6 Mix, research grade & & \\
\multirow{2}{*}{ WICO-5 } & methanol was added gravimetrically to produce a & $-15.68 \pm 0.02$ & $-114.3 \pm 1.1$ \\
& 0.05\% methanol/water volumetric ratio of & & \\
& contaminated water sample & & \\
\hline
\end{tabular}

Samples were measured on our Picarro device and results were submitted to the IAEA where data were analyzed and compared to results of other laboratories. The performance of laboratories was evaluated by z-scores based on delta deviation evaluation criteria for each isotope. An acceptable zscore was a reported result for $\delta^{18} \mathrm{O}$ or $\delta^{2} \mathrm{H}$ that did not deviate from the assigned delta value by more than twice the standard deviation for proficiency assessment (SDPA) which was set to $0.2 \%$ for $\delta^{18} \mathrm{O}$ and $1.5 \%$ for $\delta^{2} \mathrm{H}$. 

delta value and SDPA is defined as above.

The following interpretations were given to $\mathrm{z}$-score results:

$|z| \leq 2.00$ acceptable result

$2.00<|z|<3.00$ questionable result

$|z| \geq 3.00$ unacceptable result

All of our measurements of unknown samples provided acceptable results (Figs A3.1-A3.3). 


\subsection{Oxygen-18 $\left(\delta^{18} 0\right)$}

Laboratory token: 16198

Instrument 1: Laser spectrometer (Picarro L2120-i)

\begin{tabular}{|c|c|c|c|c|c|c|c|c|c|c|c|c|c|}
\hline \multirow{2}{*}{ Sample } & \multicolumn{4}{|c|}{ Reported values } & \multicolumn{4}{|c|}{ Assigned values } & \multirow{2}{*}{ Outlier } & \multirow{3}{*}{$\begin{array}{c}\text { Bias } \\
+0.05\end{array}$} & \multirow{3}{*}{$\begin{array}{c}\begin{array}{c}\text { Score } \\
\text { Points }\end{array} \\
3\end{array}$} & \multirow{2}{*}{\multicolumn{2}{|c|}{ z Score }} \\
\hline & & & & d-excess & $\delta^{1}$ & & & d-excess & & & & & \\
\hline WICO 1 & -10.75 & \pm & 0.17 & 8.6 & -10.80 & \pm & 0.02 & 9.0 & & & & 0.26 & acceptable \\
\hline WICO 2 & -5.04 & \pm & 0.15 & -1.8 & -5.11 & \pm & 0.03 & -0.8 & & +0.07 & 3 & 0.37 & acceptable \\
\hline WICO 3 & -21.98 & \pm & 0.15 & 7.4 & -22.01 & \pm & 0.05 & 7.8 & & +0.04 & 3 & 0.18 & acceptable \\
\hline WICO 4 & -0.47 & \pm & 0.13 & 3.7 & -0.50 & \pm & 0.05 & 4.5 & & +0.03 & 3 & 0.15 & acceptable \\
\hline
\end{tabular}

Total Score Points WICO 2016: 12 (Excellent)
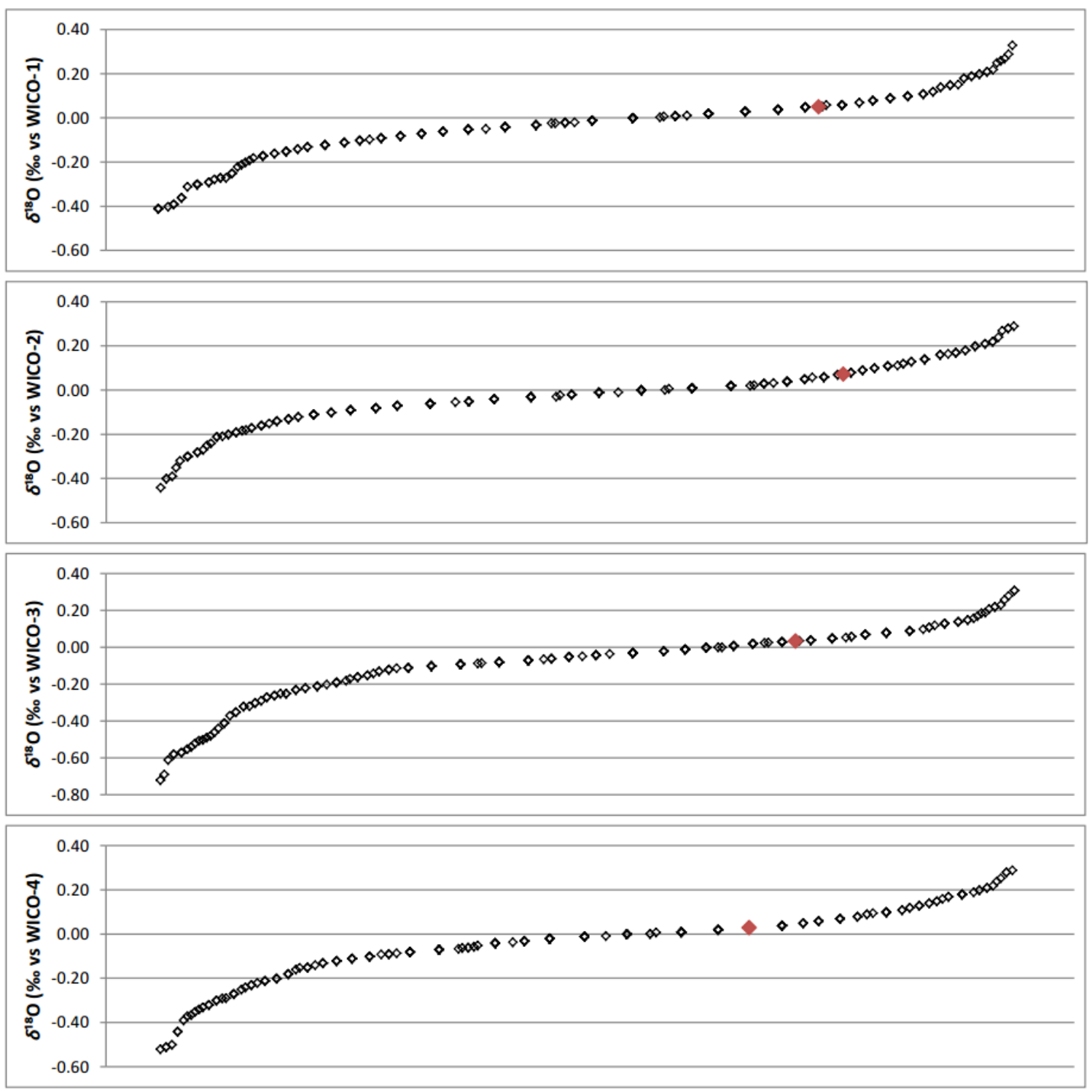

Figure A3.1: Results of the Water Isotope Inter-Comparison 2016 for $\delta^{18} \mathrm{O}$ for the samples WICO-1-4. The graphics show the delta bias from the reference value measured by our laboratory (red symbol) compared to all other laboratories. 


\subsection{Deuterium $\left(\delta^{2} \mathrm{H}\right)$}

Laboratory token: 16198

Instrument 1: Laser spectrometer (Picarro L2120-i)

\begin{tabular}{|c|c|c|c|c|c|c|c|c|c|c|c|c|c|}
\hline \multirow{3}{*}{$\begin{array}{l}\text { Sample } \\
\text { WICO } 1\end{array}$} & \multicolumn{4}{|c|}{ Reported values } & \multicolumn{4}{|c|}{ Assigned values } & \multirow{2}{*}{ Outlier } & \multirow{3}{*}{$\begin{array}{l}\text { Bias } \\
+0.1\end{array}$} & \multirow{3}{*}{$\begin{array}{c}\begin{array}{c}\text { Score } \\
\text { Points }\end{array} \\
3\end{array}$} & \multirow{2}{*}{\multicolumn{2}{|c|}{ z Score }} \\
\hline & \multirow{2}{*}{\multicolumn{3}{|c|}{$\delta^{2} \mathrm{H}$}} & -excess & \multicolumn{3}{|c|}{$\boldsymbol{\delta}^{2} \mathbf{H}$} & -excess & & & & & \\
\hline & -77.4 & & & 8.6 & -77.4 & \pm & 0.9 & 9.0 & & & & 0.03 & acceptable \\
\hline WICO 2 & -42.1 & \pm & 1.4 & -1.8 & -41.7 & \pm & 1.1 & -0.8 & & -0.4 & 3 & 0.27 & acceptable \\
\hline WICO 3 & -168.4 & \pm & 1.6 & 7.4 & -168.3 & \pm & 1.0 & 7.8 & & -0.1 & 3 & 0.08 & acceptable \\
\hline WICO 4 & -0.1 & \pm & 1.3 & 3.7 & 0.5 & \pm & 1.1 & 4.5 & & -0.6 & 2 & 0.41 & acceptable \\
\hline
\end{tabular}

\section{Total Score Points WICO 2016: 11 (Excellent)}

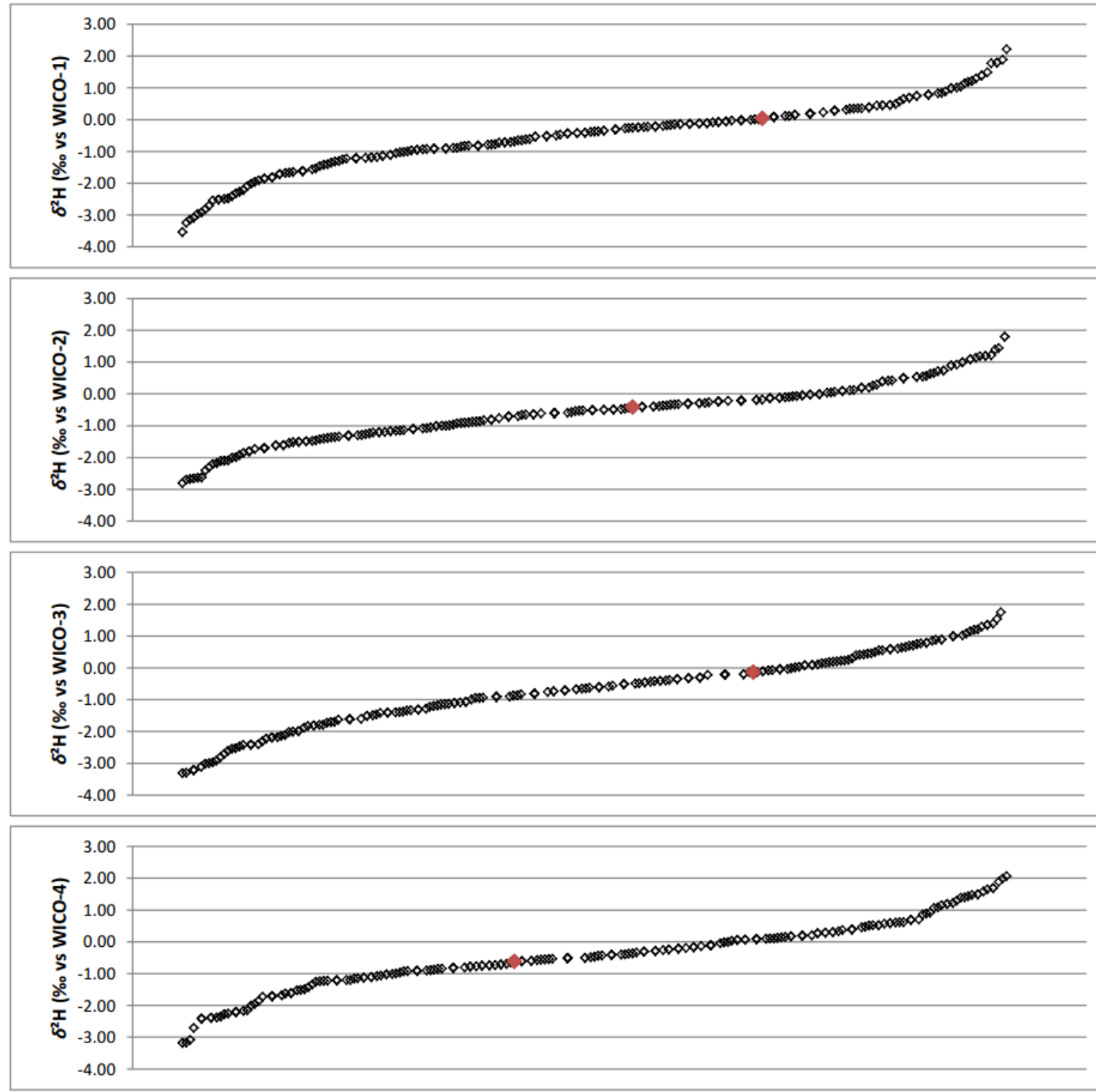

Figure A3.2: Results of the Water Isotope Inter-Comparison 2016 for $\delta^{2} \mathrm{H}$ for the samples WICO-1-4. The graphics show the delta bias from the reference value measured by our laboratory (red symbol) compared to all other laboratories. 


\section{WICO 2016 contaminated sample (WICO 5)}

\subsection{Oxygen-18 $\left(\delta^{18} 0\right)$}

Laboratory token: 16198

Instrument 1: Laser spectrometer (Picarro L2120-i)

\begin{tabular}{|c|c|c|c|c|c|c|c|c|c|c|c|}
\hline \multirow{2}{*}{ Sample } & \multicolumn{3}{|c|}{ Reported values } & \multicolumn{3}{|c|}{ Assigned values } & \multirow{3}{*}{ Outlier } & \multirow{3}{*}{$\begin{array}{c}\text { Bias } \\
-0.04\end{array}$} & \multirow{3}{*}{$\begin{array}{l}\text { Score } \\
\text { Points }\end{array}$} & \multirow{2}{*}{\multicolumn{2}{|c|}{ z Score }} \\
\hline & & & d-excess & & & d-excess & & & & & \\
\hline WICO 5 & -15.73 & \pm 0.14 & 12.8 & -15.68 & \pm 0.02 & 11.1 & & & & 0.23 & acceptable \\
\hline
\end{tabular}

Contaminated sample identified: Yes

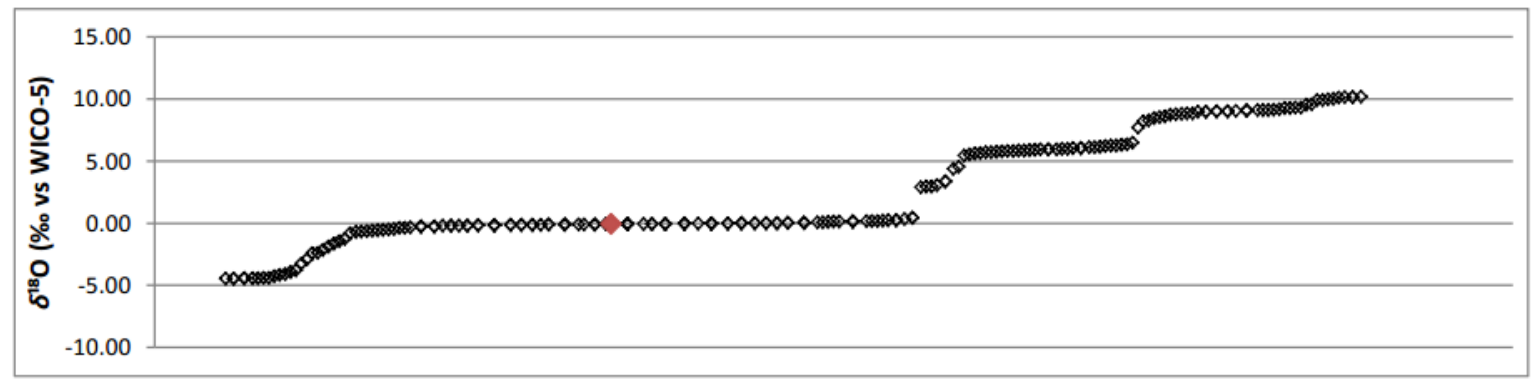

\subsection{Deuterium $\left(\delta^{2} \mathrm{H}\right)$}

Laboratory token: 16198

Instrument 1: Laser spectrometer (Picarro L2120-i)

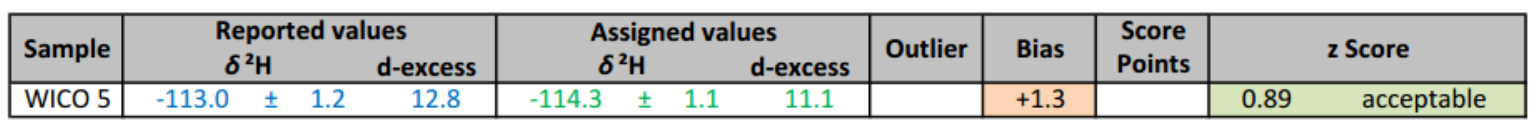

Contaminated sample identified: Yes

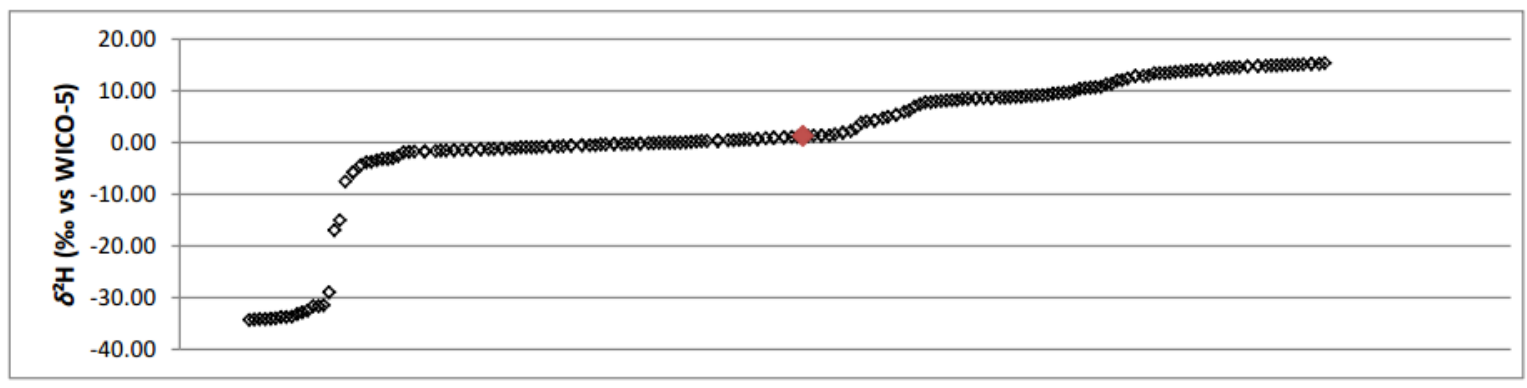

Figure A3.3: Results of the Water Isotope Inter-Comparison 2016 for $\delta^{18} \mathrm{O}$ and $\delta^{2} \mathrm{H}$-values for the contaminated sample WICO-5. The graphics show the delta bias from the reference value measured by our laboratory (red symbol) compared to all other laboratories. 
Comparison of values measured by Cavity Ring-Down Spectroscopy combined with a MicroCombustion Module and Isotope Ratio Mass Spectroscopy

Several studies have found discrepancies between isotope values measured by CRDS compared to Isotope Ratio Mass Spectroscopy (IRMS) in samples contaminated with organic compounds which are co-distilled during cryogenic vacuum extraction and may cause spectral interferences in CRDS (West et al. 2010; Zhao et al. 2011; Brand et al. 2009). To overcome this issue, we coupled a MicroCombustion Module (MCM) between the vaporizer and the analyzer of the Picarro instrument which converts organic contaminants to water and carbon dioxide by oxidation in a heated metal catalyst and thus removing spectral interferences from alcohols and other plant products. In addition, data were checked for remaining potential contamination of samples by the ChemCorrectTM software (Picarro inc.). This software marks analyzed samples as possibly contaminated or highly contaminated. A spectral contamination post-processing correction of $\delta^{2} \mathrm{H}$ and $\delta^{18} \mathrm{O}$ values can be applied to the raw output which provides values of $\mathrm{H} 218 \mathrm{O}, \mathrm{HD} 16 \mathrm{O}$ and $\mathrm{H} 216 \mathrm{O}$ peaks filtered by spectral features of organic compounds according to the equations A.1 and A.2 as given in MartinGomez et al. (2015).

$\delta{ }^{2} \mathrm{H}=$ slope $\cdot\left(\frac{\mathrm{HD}^{16} \mathrm{O}}{\mathrm{H}_{2}{ }^{16} \mathrm{O}}\right)+$ offset

\section{Equation A.1}

$\delta^{18} \mathrm{O}=$ slope $\cdot\left(\frac{\mathrm{H}_{2}{ }^{18} \mathrm{O}}{\mathrm{H}_{2}{ }^{16} \mathrm{O}}\right)+$ offset

\section{Equation A.2}

with slope and offset as factory calibration settings given by Picarro Inc..

Effectiveness of the MCM pre-treatment of samples and the given post-processing of data has been investigated by Martin-Gomez et al. (2015). They conclude that the MCM outperformed the postprocessing correction in removing interferences caused by methanol contamination, but did not effectively remove interference for high concentrations of ethanol and suggest that using both approaches for samples with unknown contaminants, CRDS can deliver reasonable accuracy of measurements of contaminated samples.

Although our results of the WICO revealed acceptable results for the methanol-contaminated sample (WICO-5), we conducted parallel measurements of samples by the Picarro water analyzer with MCM and by IRMS conducted at the Center for Stable Isotope Research (KOSI, University of Göttingen, Germany) using a MAT 253 mass spectrometer combined with a Conflo IV Interface (TC/EA, Thermo-Fisher Scientific, Bremen, Germany) to rule out potential interferences of our samples. Samples were collected in the salt marsh sites (plant and soil material from all three salt marsh zones) 
and water was extracted by cryogenic vacuum extraction. Additionally, pure water samples of a wide range of isotopic composition were analyzed using both methods (CRDS and IRMS).

Over the range of $\delta$-values measured, the $\delta^{18} \mathrm{O}$-values from both instruments agreed very well with $\mathrm{R}^{2}$ $=0.996$ for the correlation over all samples $\left(\delta^{18} \mathrm{O}_{\mathrm{CRDS}}=0.96 \cdot \delta^{18} \mathrm{O}_{\text {IRMS }}-0.53\right)$. For the $\delta^{2} \mathrm{H}$-values the CRDS and IRMS results were also significantly correlated with $\mathrm{R}^{2}=0.998$ and $\delta^{2} \mathrm{H}_{\mathrm{CRDS}}=0.996$. $\delta^{2} \mathrm{H}_{\text {IRMS }}-0.63$. For both isotopes, linear regression models lay close to the 1:1 reference line (Fig. A3.4). Differences between $\delta$-values measured by the Picarro L2120-i water analyzer and values measured by IRMS ( $\Delta \delta$-value) ranged from -0.9 to $1.1 \%$ for $\delta^{18} \mathrm{O}$ and from -3.6 to $4.2 \%$ o $\delta^{2} \mathrm{H}$ (Fig. A3.5). The mean difference between IRMS and CRDS measurements was between 0.354 (pure water samples) and $0.515 \%$ (extracted root water) for $\delta^{18} \mathrm{O}$ and between 1.023 (extracted root water) and $2.311 \%$ (pure water samples) for $\delta^{2} \mathrm{H}$. There was no significant effect of the type of water measured (pure water sample or samples extracted from organic material) on the difference between IRMS and CRDS measurements ( $p=0.07$ for $\delta^{18} \mathrm{O}$ and $p=0.23$ for $\delta^{2} \mathrm{H}$ ). Based on these results, we assumed to achieve reliable results from measurements performed by our Picarro device with MCM and subsequent post-processing of data.
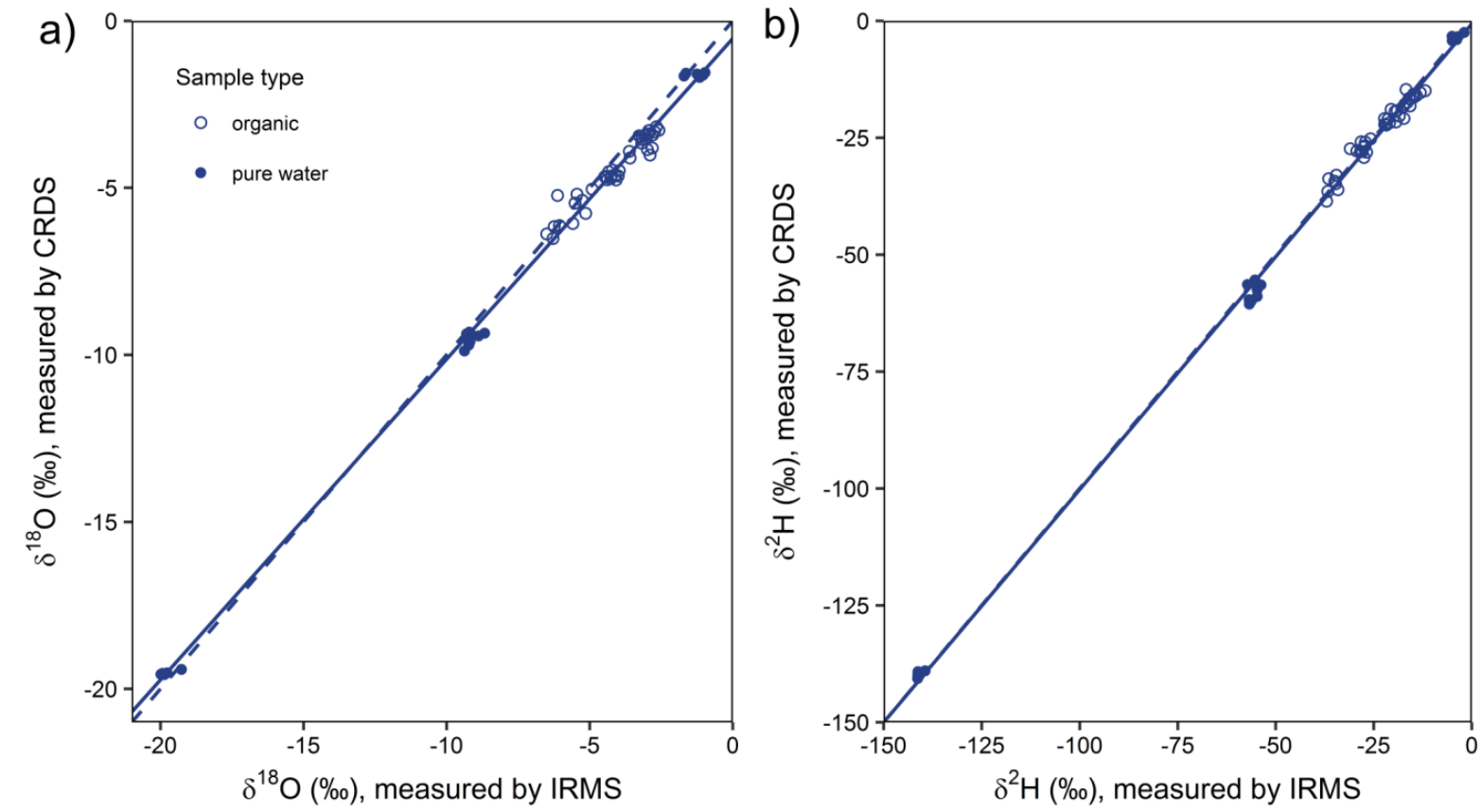

Figure A3.4: Comparison of $\delta$-values of ${ }^{18} \mathrm{O}$ (a) and ${ }^{2} \mathrm{H}$ (b) measured by a Picarro L2120-i water analyzer (CRDS) with values measured by isotope ratio mass spectroscopy (IRMS) of pure water samples (filled circles) and water extracted from organic samples (soil and root material, open circles). Data were organic-corrected. Solid lines represent a linear regression model (Model II, ranged major axis) with $y=0.96 \mathrm{x}-0.53, \mathrm{R}^{2}=0.996$ $\left(\delta^{18} \mathrm{O}\right)$ and $\mathrm{y}=0.996 \mathrm{x}-0.63, \mathrm{R}^{2}=0.998\left(\delta^{2} \mathrm{H}\right)$. Dashed lines give the $1: 1$ reference line (slope 1, intercept 0 ). 
a)

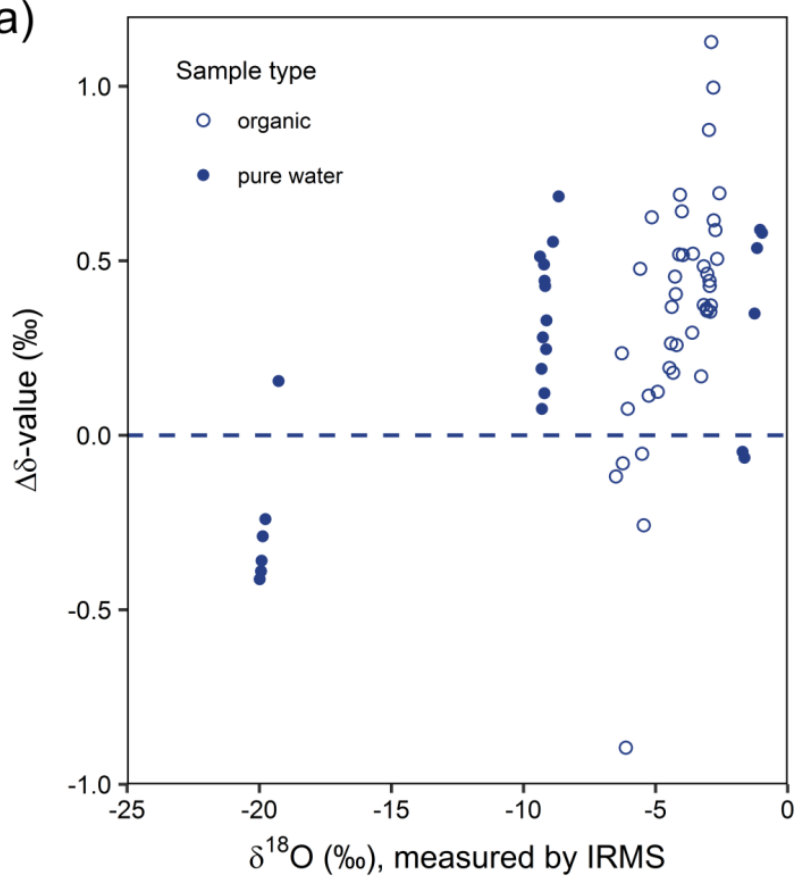

b)

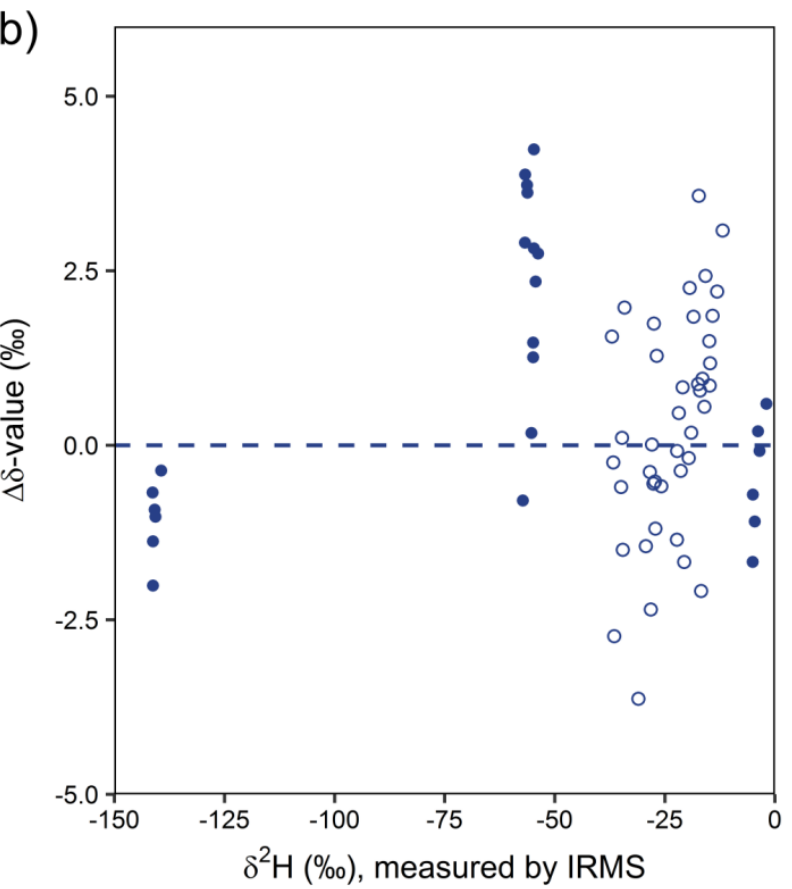

Figure A3.5: Difference between $\delta$-values of ${ }^{18} \mathrm{O}$ (a) and ${ }^{2} \mathrm{H}$ (b) measured by a Picarro L2120- $i$ water analyzer (CRDS) and values measured by isotope ratio mass spectroscopy (IRMS) of pure water samples (filled circles) and water extracted from organic samples (soil and root material, open circles). 


\section{References}

Araguás-Araguás L, Rozanski K, Gonfiantini R, Louvat D (1995) Isotope effects accompanying vacuum extraction of soil water for stable isotope analyses. Journal of Hydrology 168:159-171.

Brand WA, Geilmann H, Crosson ER, Rella CW (2009) Cavity ring-down spectroscopy versus hightemperature conversion isotope ratio mass spectrometry; a case study on $\delta^{2} \mathrm{H}$ and $\delta^{18} \mathrm{O}$ of pure water samples and alcohol/water mixtures. Rapid Communications in Mass Spectrometry 23:1879-1884. doi:10.1002/rcm.4083.

Dalton FN (1988) Plant root water extraction studies using stable isotopes. Plant and Soil 111:217221.

Dawson TE, Ehleringer JR (1993) Isotopic enrichment of water in the woody tissues of plants implications for plant water source, water uptake, and other studies which use the stable isotopic composition of cellulose. Geochimica et Cosmochimica Acta 57:3487-3492.

Ingraham NL, Shadel C (1992) A comparison of the toluene distillation and vacuum/heat methods for extracting soil water for stable isotopic analysis. Journal of Hydrology 140:371-387. doi:10.1016/0022-1694(92)90249-U.

Koeniger P, Marshall JD, Link T, Mulch A (2011) An inexpensive, fast, and reliable method for vacuum extraction of soil and plant water for stable isotope analyses by mass spectrometry. Rapid Communications in Mass Spectrometry 25:3041-3048. doi:10.1002/rcm.5198.

Martin-Gomez P, Barbeta A, Voltas J, Penuelas J, Dennis K, Palacio S, Dawson TE, Ferrio JP (2015) Isotope-ratio infrared spectroscopy: a reliable tool for the investigation of plant-water sources? New Phytologist 207:914-927. doi:10.1111/nph.13376.

Meißner M, Köhler M, Schwendenmann L, Hölscher D, Dyckmans J (2014) Soil water uptake by trees using water stable isotopes $\left(\delta^{2} \mathrm{H}\right.$ and $\left.\delta^{18} \mathrm{O}\right)-$ a method test regarding soil moisture, texture and carbonate. Plant and Soil 376:327-335. doi:10.1007/s11104-013-1970-z.

Orlowski N, Breuer L, Angeli N, Boeckx P, Brumbt C, Cook CS, Dubbert M, Dyckmans J, Gallagher B, Gralher B, Herbstritt B, Hervé-Fernández P, Hissler C, Koeniger P, Legout A, Macdonald CJ, Oyarzún C, Redelstein R, Seidler C, Siegwolf R, Stumpp C, Thomsen S, Weiler M, Werner C, McDonnell JJ (2018) Inter-laboratory comparison of cryogenic water extraction systems for stable isotope analysis of soil water. Hydrology and Earth System Sciences 22:3619-3637. doi:10.5194/hess-22-3619-2018.

Orlowski N, Breuer L, McDonnell JJ (2016) Critical issues with cryogenic extraction of soil water for stable isotope analysis. Ecohydrology 9:1-5. doi:10.1002/eco.1722.

Orlowski N, Frede H-G, Brüggemann N, Breuer L (2013) Validation and application of a cryogenic vacuum extraction system for soil and plant water extraction for isotope analysis. Journal of Sensors and Sensor Systems 2:179-193. doi:10.5194/jsss-2-179-2013.

Redelstein R, Coners H, Knohl A, Leuschner C (2018) Water sources of plant uptake along a salt marsh flooding gradient. Oecologia 188:607-622. doi:10.1007/s00442-018-4229-9. 
West AG, Goldsmith GR, Brooks PD, Dawson TE (2010) Discrepancies between isotope ratio infrared spectroscopy and isotope ratio mass spectrometry for the stable isotope analysis of plant and soil waters. Rapid Communications in Mass Spectrometry 24:1948-1954. doi:10.1002/rcm.4597.

West AG, Patrickson SJ, Ehleringer JR (2006) Water extraction times for plant and soil materials used in stable isotope analysis. Rapid Communications in Mass Spectrometry 20:1317-1321. doi:10.1002/rcm.2456.

Zhao L, Xiao H, Zhou J, Wang L, Cheng G, Zhou M, Yin L, McCabe MF (2011) Detailed assessment of isotope ratio infrared spectroscopy and isotope ratio mass spectrometry for the stable isotope analysis of plant and soil waters. Rapid Communications in Mass Spectrometry 25:3071-3082. doi:10.1002/rcm.5204. 


\section{Index of Figures}

Figure 1.1: Global distribution of vegetated coastal ecosystems including seagrasses, salt marshes and

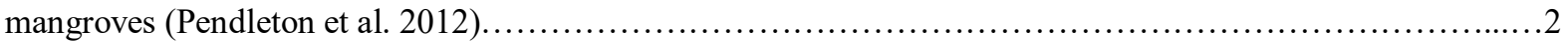

Figure 1.2: The three zones of a NW European salt marsh with their elevations relative to the Mean High Tide (MHT) level and characteristic species. Mean High Water of Neap tides (MHWN) marks the transition from the bare tidal flat to the pioneer zone. Figure by D. Hertel and R. Redelstein. .4

Figure 1.3: Typical vegetation of the three saltmarsh zones in the study areas. a) Establishing vegetation (Salicornia sp.) on a bare tidal flat. b) Lower salt marsh (front) and pioneer zone (Spartina anglica dominated, back) vegetation during tidal inundation. c) Lower saltmarsh vegetation (mainly Limonium vulgare, Atriplex portulacoides, Aster tripolium and Triglochin maritimum). d) Upper salt marsh with a monospecific stand of Elytrigia atherica. Photographs: R. Redelstein. 6

Figure 1.4: Map of the German North Sea coast with the location of the two study sites Spiekeroog Island and Westerhever and location of the sampling plots in the three saltmarsh zones pioneer zone (Pio), lower salt marsh (Low) and upper salt marsh (Upp) (detailed satellite images: Tümlau Bight in Westerhever (A) and south side of Spiekeroog Island (B)) (Service layer Credits: Esri, DeLorme, GEBCO, NOAA NGDB, and other contributors, Source: Esri, DigitalGlobe, GeoEye, Earthstar Geographics, CNES/Airbus DS, USDA, USGS,

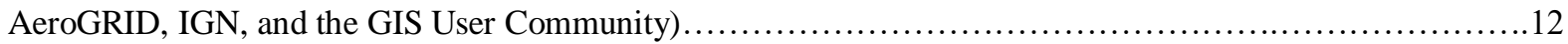

Figure 1.5: A) Design of the experimental islands as given in Balke et al. (2017). B) Experimental islands during tidal flooding. C) View from above on the lower level of an experimental island with four plots of $1 \mathrm{x}$ $1 \mathrm{~m}$. D) Bare plots of experimental islands with first colonization after one year. E) Experimental island plot with vegetation from the lower salt marsh.

Figure 2.1: The three zones of a NW European salt marsh with their elevations relative to the Mean High Tide (MHT) level and characteristic species. Mean High Water of Neap tides (MHWN) marks the transition from the bare tidal flat to the pioneer zone. Figure modified from Redelstein et al. (2018)...........................27

Figure 2.2: (a) Mesocosm with experimental pots containing seedlings of Salicornia europaea, Atriplex portulacoides and Elytrigia atherica grown from seeds collected from a NW European salt marsh. The pots were prepared in order to simulate 3 different levels of waterlogging (1) drained, (2) partly waterlogged and (3) waterlogged. (B) Design and implementation of a test to simulate erosion and determine the critical erosion depth (Ecrit) of each species. Photographs: R. Redelstein....

Figure 2.3: Growth of Salicornia europaea, Atriplex portulacoides and Elytrigia atherica seedlings during the experiment depending on waterlogging treatments. Dots represent measurements of individual seedlings; lines represent predictions of a three-parameter logistic model for the different treatments. Note overlaying lines under different treatments for S. europaea and A. portulacoides.....

Figure 2.4: Root and shoot growth rates, and measures of root morphology for Salicornia europaea, Atriplex portulacoides and Elytrigia atherica seedlings grown under different waterlogging treatments (drained, partly waterlogged, waterlogged). Horizontal lines indicate median values, boxes the interquartile range, and error bars minimum and maximum values. Open circles represent outliers. Where the interaction was significant, different lower case letters indicate statistical differences between treatments within species, while different 
upper case letters mark significant differences between species within treatments according to one-way ANOVA with Tukey's HSD tests $(p<0.05)$. Elsewhere, different lower case letters indicate significant differences comparing species and treatments by two-way factorial ANOVA with Tukey's HSD tests

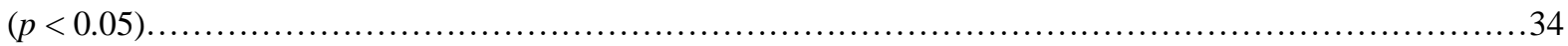

Figure 2.5: Critical erosion depth of Salicornia europaea, Atriplex portulacoides and Elytrigia atherica seedlings depending on sediment conditions in the greenhouse experiment and of Salicornia sp. seedlings grown under natural field conditions. Lower case letters mark statistically significant differences between treatments within species, upper case letters mark statistically significant differences between species within treatments (Kruskal-Wallis multiple comparisons, significance level $p<0.05$ ). 36

Figure 2.6: Results of Principal components analysis (PCA) of factors influencing seedling stability in response to erosion for Atriplex portulacoides (triangle), Salicornia spp. (circle), and Elytrigia atherica (square). Seedlings were subjected to three treatments: drained, partly waterlogged (partly-wl) and completely waterlogged (wl); in addition seedlings of Salicornia spp. were grown under natural field conditions. Factors considered in the analysis included measures of seedling size and the critical erosion depth $\left(\mathrm{E}_{\text {crit }}\right)$ determined for each species under different conditions (see Fig. 2.5). For detailed results of the PCA see Table S2.3). Abbreviations: r.length: root length; s.height: shoot height; root bm: root biomass; shoot bm: shoot biomass; ratio length: ratio of root length to shoot length; ratio bm: ratio of root biomass to shoot biomass; EV: eigenvalues.

Figure 3.1: A) Map of the German North Sea coast with the location of the two study sites Spiekeroog Island and Westerhever and location of the sampling plots in the three saltmarsh zones pioneer zone (Pio), lower salt marsh (Low) and upper salt marsh (Upp). Detail maps: Tümlau Bight in Westerhever (a) and south side of Spiekeroog Island (b). "T" marks the location of the tide gauge station from which water level data for Westerhever were obtained (Service layer Credits: Esri, DeLorme, GEBCO, NOAA NGDB, and other contributors, Source: Esri, DigitalGlobe, GeoEye, Earthstar Geographics, CNES/Airbus DS, USDA, USGS, AeroGRID, IGN, and the GIS User Community). B) Zonation of a salt marsh with elevations relative to the mean high tide (MHT) water level and species typically inhabiting the three zones in a north-west European salt marsh. 56

Figure 3.2: Aboveground biomass and fine root mass in the three saltmarsh communities at the two study sites $(\mathrm{n}=6$, means $\pm \mathrm{SE})$. Different letters indicate significant differences between communities at a site $(\mathrm{a}, \mathrm{b})$ or between the sites within a community type (A,B) (Kruskal-Wallis multiple comparison test, $p<0.05$ ). Letters inside the bars indicate significant differences for different sediment horizons, letters below bars stand for the entire soil profile.

Figure 3.3: Cumulative fine root surface area per $\mathrm{m}^{2}$ ground area in the profile to $40 \mathrm{~cm}$ depth in the three saltmarsh communities at the study sites Spiekeroog and Westerhever ( $n=6$, means \pm SE). Different letters indicate significant differences between the communities at a site $(a, b)$ or between the two sites for a community type (A,B) according to Kruskal-Wallis multiple comparison tests $(p<0.05)$. Letters inside of the bars indicate significant differences for a given sediment horizon, letters above bars stand for the entire soil profile.

Figure 3.4: Change in fine root density (fine root mass per soil volume) with soil depth in the three saltmarsh communities $($ Pio $=$ pioneer zone, Low $=$ lower salt marsh and Upp $=$ upper salt marsh) at the study sites Spiekeroog and Westerhever $(\mathrm{n}=6$, means $\pm \mathrm{SE})$. ...64 
Figure 3.5: Means \pm SE of five fine root morphological traits in the three saltmarsh communities (Pio = pioneer zone, Low $=$ lower salt marsh and Upp $=$ upper salt marsh) at the study sites Spiekeroog and Westerhever $(\mathrm{n}=24)$. Different letters indicate significant differences between study sites and saltmarsh communities

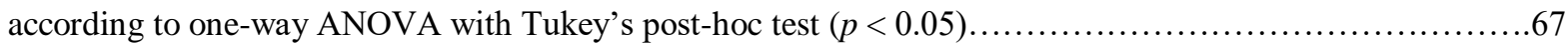

Figure 3.6: Plot showing the distribution of the three saltmarsh communities $(\mathrm{Pio}=$ pioneer zone, Low $=$ lower salt marsh and Upp = upper salt marsh) of the two sites Spiekeroog (S) and Westerhever (WH) in relation to the PCA axes 1 and 2 (EV: eigenvalues of the axes) and their association with important soil and root properties (SRA: specific root area, $\Sigma \mathrm{T}$ : clay fraction, RAI: root area index, FRM: fine root mass, root $\mathrm{N}$ : root $\mathrm{N}$ concentration, $\sum \mathrm{S}$ : sand fraction, $\mathrm{H}$ : Shannon-Wiener index, $\mathrm{Na}$ : $\mathrm{Na}_{\mathrm{t}}$ concentration in the sediment, flooding: no. of monthly flooding events, P: total P in the sediment, Pav: plant-available P in the sediment, RTD: root tissue density, $\sum \mathrm{U}$ : silt fraction, Nmin: mineral $\mathrm{N}$ concentration $\left(\mathrm{NO}_{3}{ }^{-}\right.$and $\left.\mathrm{NH}_{4}{ }^{+}\right)$in soil) in the upper soil horizon $\left(\mathrm{A}_{h}\right)$. Vector length and angle are proportional to the direction and degree of their correlation with the

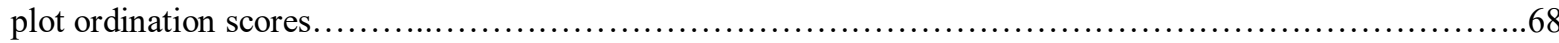

Figure S3.1: Plot showing the distribution of the three saltmarsh zones (Pio, Low and Upp) in the two saltmarsh sites Spiekeroog (S) and Westerhever (WH) in PCA axes 1 and 2 with soil and root properties (SRA: specific root area, $\sum \mathrm{T}$ : clay fraction, RAI: root area index, FRM: fine root mass, root N: root $\mathrm{N}$ concentration, $\sum \mathrm{S}$ : sand fraction, H: Shannon-Wiener index, Na: Na concentration in soil, flooding: monthly flooding events, P: total P in soil, Pav: plant-available P in soil, RTD: root tissue density, $\sum \mathrm{U}$ : silt fraction, Nmin: mineral N $\left(\mathrm{NO}_{3}{ }^{-}\right.$and $\left.\mathrm{NH}_{4}{ }^{+}\right)$in soil) related to the deeper soil horizon $\left(\mathrm{G}_{\mathrm{o}} / \mathrm{G}_{\mathrm{r}}\right)$. Vector length and angle are proportional to the direction and degree of their correlation with the plot ordination scores............................... 79

Figure S3.2: Above-ground vs. below-ground (fine root) biomass (dry weight) at nine plots in two saltmarsh sites (means $\pm \mathrm{SD}, \mathrm{n}=4-6$ ). Plot names with an "O" are located in an ungrazed salt marsh on the Hallig island Oland, plot names with an "S" are located in a grazed salt marsh at Sönke-Nissen-Koog (both are located in Schlswig-Holstein, Germany). The first letter of the plot name refers to the plant community: "AO": Elytrigia atherica dominated (Oland), "BO": Spartina anglica with Aster tripolium (Oland), "CO": Spartina anglica dominated Oland, "DO": Atriplex portulacoides dominated (Oland), "FO": Spartina anglica dominated Oland, "AS" Spartina anglica dominated (Sönke-Nissen-Koog), "BS": Puccinellia maritima dominated (Sönke-NissenKoog), "DAS": Spartina anglica dominated at a scoured location (Sönke-Nissen-Koog), "DSB": Puccinellia maritima dominated on an elevated location (Sönke-Nissen-Koog). Data collected by Rita Strieckmann (1989,

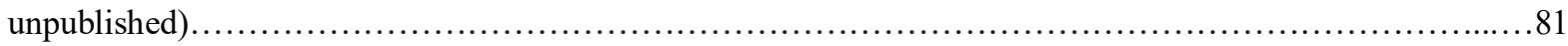

Figure 4.1: $\delta^{2} \mathrm{H}$ versus $\delta^{18} \mathrm{O}$ signatures of different plant water sources (seawater, precipitation water, soil water) and plant water sampled at Spiekeroog Island. In addition to the local water line (LWL) and plant water line (PWL), the global meteoric water line (GMWL; Craig 1961) is shown (dashed line).

Figure 4.2a)-e): $\delta^{18} \mathrm{O}$ values of soil water (open symbols) depending on soil depth (means $\pm \mathrm{se}, \mathrm{n}=6$ ) extracted from the soil in the three salt marsh zones (upper salt marsh (Upp), lower salt marsh (Low), pioneer zone (Pio)) on Spiekeroog Island (control plots) and on the experimental islands. Closed symbols and the dashed vertical lines represent plant water $\delta^{18} \mathrm{O}$ (mean) with shaded areas as standard error (plant species: Upp: Elytrigia atherica, Low: Atriplex portulacoides, Pio: Spartina anglica, Experimental islands: Atriplex portulacoides in all three zones). Filled diamonds represent the $\delta^{18} \mathrm{O}$ signature of precipitation water and open diamonds the $\delta^{18} \mathrm{O}$ signature of seawater sampled on the days before soil and plant material sampling.

Figure 4.3a)-e): Contribution of precipitation and seawater to plant water in the three salt marsh zones (upper salt marsh (Upp), lower salt marsh (Low), pioneer zone (Pio)) on Spiekeroog Island (Control plots) and on the experimental islands (plant species: Upp: Elytrigia atherica, Low: Atriplex portulacoides, Pio: Spartina 
anglica, Experimental islands: Atriplex portulacoides in all three zones) at three sampling dates. Presented are means \pm se $(n=6)$. Different small letters indicate statistically significant differences among salt marsh zones on a sampling date and within a treatment, capital letters indicate differences between control plots and experimental islands within salt marsh zones (Tukey HSD tests, $p<0.05$ ). . .

Figure 4.4a)-e): Contribution of soil layers to plant water uptake in the three salt marsh zones (upper salt marsh (Upp), solid line, lower salt marsh (Low), dashed line, pioneer zone (Pio), dot-dashed line) on Spiekeroog Island (Control plots) and on the experimental islands at three sampling dates (plant species: Upp: Elytrigia atherica, Low: Atriplex portulacoides, Pio: Spartina anglica; on experimental islands Atriplex portulacoides in all three zones). Values were calculated by means of a Bayesian calibrated stable isotope mixing model (package 'simmr') based on measured water isotope data of soil and plants. Given are means \pm sd $(n=6) \ldots .103$

Figure 4.5: a) Linear regression model showing the correlation between the contribution of a specific soil depth to plant water uptake and the proportion of total fine root mass in that soil depth in the salt marsh of Spiekeroog Island and on the experimental islands $(\mathrm{y}=0.63 \mathrm{x}+11.47, p<0.001)$. Values from different salt marsh zones are presented in different colors, values from different soil depths by different symbols. The grey area indicates the $95 \%$ confidence interval. b) Relative water uptake per fine root mass in the different soil layers. Different letters indicate statistically significant differences (Kruskal-Wallis multiple comparisons, $p<0.05$ ). 104

Figure 4.6: Difference among the three salt marsh zones between measured plant water $\delta^{2} \mathrm{H}$-values and plant water $\delta^{2} \mathrm{H}$-values calculated under the assumption of no ${ }^{2} \mathrm{H}$-discrimination during plant water uptake given for the three sampling campaigns. Asterisks indicate statistically significant differences between plant water and soil water $\delta^{2} \mathrm{H}$-values (Welch two sample t-test, $p<0.05$ ).

Figure S4.1: a) Location of Spiekeroog Island on the German North Sea coast and close-up of sampling plot locations (upper salt marsh (Upp), lower salt marsh (Low), pioneer zone (Pio), experimental islands) on the south side of the barrier island. The location of the experimental islands is indicated by the numbers 1-6 (Service layer Credits: Esri, DeLorme, GEBCO, NOAA, NGDB, and other contributors, Source: Esri, DigitalGlobe, GeoEye, Earthstar Geographics, CNES/Airbus DS, USDA, USGS, AeroGRD, IGN, and the GIS User Community). b) Setup of experimental islands and close-up of the steel cages planted with vegetation from the lower salt marsh (photographs: R. Redelstein). 110

Figure S4.2: Daily precipitation during the year of sampling campaigns from September 2014 to August 2015. Sampling campaigns are marked by arrows. Data were obtained from the German Meteorological Service (Deutscher Wetterdienst) and represent values for Norderney, $40 \mathrm{~km}$ apart from our sampling location (http://www.dwd.de/DE/leistungen/klimadatendeutschland/klarchivtagmonat.html?nn=16102).

Figure S4.3: Comparison of $\delta$-values of ${ }^{18} \mathrm{O}$ and ${ }^{2} \mathrm{H}$ measured by a Picarro L2120-i water analyzer (CRDS) with values measured by isotope ratio mass spectroscopy (IRMS) of pure water samples (filled circles) and water extracted from organic samples (soil and root material, open circles). Data were organic-corrected. Solid lines represent a linear regression model (Model II, ranged major axis) with $y=0.96 \mathrm{x}-0.53, \mathrm{R}^{2}=0.996\left(\delta^{18} \mathrm{O}\right)$ and $y=0.996 x-0.63, R^{2}=0.998\left(\delta^{2} H\right)$. Dashed lines give the 1:1 reference line (slope 1, intercept 0$) \ldots \ldots .112$

Figure 5.1: Below-ground carbon (a) and nitrogen (b) pools in fine root mass in the three saltmarsh communities at the two study sites (means \pm SE). Different letters indicate significant differences between

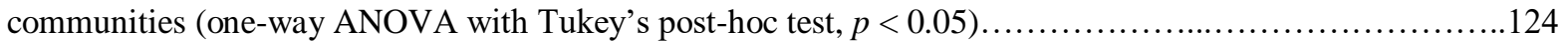

Figure A1.1: Set up of the cryogenic-vacuum extraction line. 137 
Figure A1.2: a) Close up of an extraction unit: V-shaped extraction tubes placed in a thermobox for liquid nitrogen where the extracted water is trapped. b-d) Connection of the sample tubes to the V-tubes. In b) samples are filled into glass tubes which are connected to the extraction system by rubber seals and clips ('Method 1'). c and d): For direct extraction from Labco® sampling vials, the V-tubes are closed with a stopper pierced by a cannula. The septum of the vials is then pierced by the cannula and thus, connected to the extraction system ('Method 2')..... 138

Figure A2.1: Results of the water-water-extraction tests for the validation of the cryogenic vacuum extraction line. $\delta^{18} \mathrm{O}$ (a) and $\delta^{2} \mathrm{H}$ (b) values were measured from three different types of water (note that water types differed between the two extraction methods) which were extracted with two different methods. Isotopic values are compared to unextracted water. Solid lines represent the value of unextracted water, dashed lines the threshold of $\pm 0.2 \%$ for $\delta^{18} \mathrm{O}$ and $\pm 1.5 \%$ o $\delta^{2} \mathrm{H}$ defined by the IAEA.

Figure A2.2: Results of the water-water-extraction tests to compare directly between the two extraction methods. $\delta^{18} \mathrm{O}$ (a) and $\delta^{2} \mathrm{H}$ (b) values were measured from two different types of water which were extracted with both methods. Solid lines represent the value of unextracted water, dashed lines the threshold of $\pm 0.2 \%$ for $\delta^{18} \mathrm{O}$ and $\pm 1.5 \% \delta^{2} \mathrm{H}$ defined by the IAEA

Figure A2.3: Effect of cryogenic extraction parameters (duration, temperature, and pressure) on $\delta^{2} \mathrm{H}$ results of both soil types (clayey loam and silty sand) and water contents (8 and $20 \%)$ shown for all labs. The mean reference DI water $\delta^{2} \mathrm{H}$ value is shown as a red dotted line (Orlowski et al. 2018) 143

Figure A2.4: Mean differences from reference DI water $(\Delta)$ for $\delta^{18} \mathrm{O}(\mathrm{a})$ and $\delta^{2} \mathrm{H}$ (b) results of water extracts from both extraction procedures (lab internal and pre-defined), extraction methods (glass tubes and cannula), soil types (clayey loam and silty sand) and water contents $(8 \%$ and $20 \%$ ). Solid lines represent a $\Delta \delta$-value of $0 \%$, dashed lines the threshold of $\pm 0.2 \%$ for $\delta^{18} \mathrm{O}$ and $\pm 1.5 \% \delta^{2} \mathrm{H}$ defined by the IAEA 144

Figure A3.1: Results of the Water Isotope Inter-Comparison 2016 for $\delta^{18} \mathrm{O}$ for the samples WICO-1-4. The graphics show the delta bias from the reference value measured by our laboratory (red symbol) compared to all other laboratories. 147

Figure A3.2: Results of the Water Isotope Inter-Comparison 2016 for $\delta^{2} \mathrm{H}$ for the samples WICO-1-4. The graphics show the delta bias from the reference value measured by our laboratory (red symbol) compared to all other laboratories. 148

Figure A3.3: Results of the Water Isotope Inter-Comparison 2016 for $\delta^{18} \mathrm{O}$ and $\delta^{2} \mathrm{H}$-values for the contaminated sample WICO-5. The graphics show the delta bias from the reference value measured by our laboratory (red symbol) compared to all other laboratories.

Figure A3.4: Comparison of $\delta$-values of ${ }^{18} \mathrm{O}$ (a) and ${ }^{2} \mathrm{H}$ (b) measured by a Picarro L2120-i water analyzer (CRDS) with values measured by isotope ratio mass spectroscopy (IRMS) of pure water samples (filled circles) and water extracted from organic samples (soil and root material, open circles). Data were organic-corrected. Solid lines represent a linear regression model (Model II, ranged major axis) with $\mathrm{y}=0.96 \mathrm{x}-0.53, \mathrm{R}^{2}=0.996$ $\left(\delta^{18} \mathrm{O}\right)$ and $\mathrm{y}=0.996 \mathrm{x}-0.63, \mathrm{R}^{2}=0.998\left(\delta^{2} \mathrm{H}\right)$. Dashed lines give the $1: 1$ reference line (slope 1 , intercept $0)$.

Figure A3.5: Difference between $\delta$-values of ${ }^{18} \mathrm{O}$ (a) and ${ }^{2} \mathrm{H}$ (b) measured by a Picarro L2120- $i$ water analyzer (CRDS) and values measured by isotope ratio mass spectroscopy (IRMS) of pure water samples (filled circles) and water extracted from organic samples (soil and root material, open circles). 


\section{Index of Tables}

Table 2.1: Sediment redox-potential (means \pm se) measured at different sediment depths for the three treatments of the mesocosm experiment and in the three saltmarsh zones and a tidal mudflat at Spiekeroog Island (Germany). Measurements at the field site were taken during the growing period (August). Measured values were corrected by adding the potential of the reference electrode $(210 \mathrm{mV})$ with respect to the standard hydrogen electrode.

Table 2.2: Parameters of a three-parameter logistic model for the growth of Salicornia europaea, Atriplex portulacoides and Elytrigia atherica seedlings exposed to three waterlogging treatments. $\mathrm{H}_{0}$ : height at beginning of the experiment $(\mathrm{mm}), \mathrm{K}$ : shoot height at harvest $(\mathrm{mm})$; r: relative growth rate $\left(\mathrm{mm} \mathrm{mm}^{-1}\right.$ day $\left.^{-1}\right)$. Values for partly-waterlogged and waterlogged treatments are given as deviation from the drained treatment. Deviations were non-significant (restricted maximum likelihood test) except where shown: $p<0.05: *, p<$ $0.01: * *, p<0.001$ :

Table S2.1: Measures of seedling size and root morphology of Salicornia europaea, Atriplex portulacoides and Elytrigia atherica seedlings dependent on sediment treatment during the experiment and of Salicornia spp. seedlings from a natural field site. Values are given as means \pm standard deviation. Different lower case letters indicate statistical differences according to 1-way ANOVA with Tukey's HSD tests $(\mathrm{p}<0.05)$. Comparisons were conducted between treatments within species.

Table S2.2: Two-way factorial ANOVA with effects of species and treatment for measures of seedling size and root morphology of Salicornia europaea, Atriplex portulacoides and Elytrigia atherica seedlings exposed to three different sediment treatments (drained, partly-waterlogged, waterlogged) over 47 to 55 days.....

Table S2.3: Results of a Principal Components Analysis (PCA) regarding the critical erosion depth of seedlings and different measures of seedling size. Given are the loadings of the selected variables along the four main explanatory axes as well as the cumulative $\mathrm{r}^{2}$ values (in brackets) for a given variable. Numbers below the four axes indicate the eigenvalues (EV) of the axes. Numbers in bold indicate the variables with the closest relation to the respective axis. Axis 3 and 4 are not given due to their low explanation of variance. . .45

Table 3.1: Summary of soil properties at the two study sites in the salt marshes of Spiekeroog Island and Westerhever on the German North Sea coast. Given are means $( \pm$ SE) of the three saltmarsh zones and the respective soil horizons. $\mathrm{N}_{\mathrm{t}}$ and $\mathrm{C}_{\mathrm{org}}$ in the Go/Gr horizons of Spiekeroog were close to the limit of quantification and could, thus, not be used for analysis. For statistical comparisons see Table

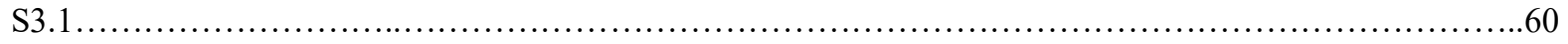

Table 3.2: Fine root mass:aboveground biomass ratio (median values) in the three saltmarsh zones at both study sites. Different letters indicate significant differences between zones within a site (a) or between sites within a zone $(\mathrm{A}, \mathrm{B})$ analyzed by Kruskal-Wallis multiple comparisons $(p<0.05) \ldots$

Table 3.3: Percentage of fine root mass in the upper $20 \mathrm{~cm}$ of soil of the total soil profile $(0-40 \mathrm{~cm})(\mathrm{means} \pm$ $\mathrm{SE}, \mathrm{n}=6)$. Different letters indicate significant differences between zones within a site $(\mathrm{a}, \mathrm{b})$ or between sites within a zone (A,B) analyzed by Kruskal-Wallis multiple comparisons $(p<0.05)$.

Table 3.4: Predictor variables for fine root mass identified by stepwise multiple regression analyses (forward and backward variable selection) grouped by study site and soil depth.... 
Table 3.5: Results of a Principal Components Analysis (PCA) on the differentiation of the three saltmarsh zones at both study sites with respect to fine root mass, root morphological traits, species diversity and soil properties of the $A_{h}$-horizon. Given are the loadings of the selected variables along the first and second explanatory axes. Numbers in brackets below the axes indicate the eigenvalues (EV) of the axes. Numbers in bold mark the variables with closest correlation to the respective axis (cumulative fit values are given in brackets).

Table 3.6: Compilation of root mass and above-ground biomass data from North Sea salt marshes up to a sediment depth of $20 \mathrm{~cm}$ from this study and for two further sites investigated by Strieckmann (1989).

Table S3.1: Results of statistical comparisons of soil properties at the two study sites in the salt marshes of Spiekeroog Island and Westerhever on the German North Sea coast (data given in Table 3.1). Different letters mark statistically significant differences between zones $(a, b)$, between sites (A,B), or between soil horizons $(\alpha$, $\beta$ ) analyzed by Kruskal-Wallis multiple comparisons $(p<0.05)$ or Welch's two sample t-test for soil horizons $(p<0.05)$

Table S3.2: Vegetation cover estimated using the LONDO scale in the six replicate sampling plots of $2 \times 2 \mathrm{~m}$ at the Westerhever site in the three saltmarsh zones ("Pio" = pioneer zone, "Low" = lower salt marsh, "Upp" =

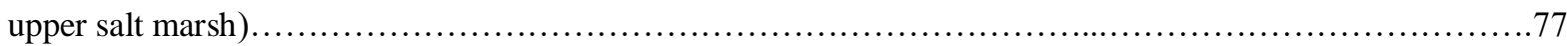

Table S3.3: Vegetation cover estimated using the LONDO scale in the six replicate sampling plots of $2 \times 2 \mathrm{~m}$ at the Spiekeroog site in the three saltmarsh zones ("Pio" = pioneer zone, "Low" = lower salt marsh, "Upp" =

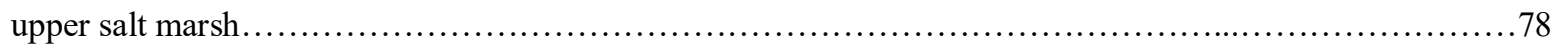

Table S3.4: Results of a Principal Components Analysis (PCA) on the differentiation of the 3 saltmarsh zones at both study sites with respect to fine root mass, root morphological traits, species diversity and soil properties of the Go/Gr horizon. Given are the loadings of the selected variables along the first three explanatory axes. Numbers in brackets below the axes indicate the eigenvalues (EV) of the axes. Numbers in bold mark the variables with closest correlation to the respective axis (cumulative fit values are given in

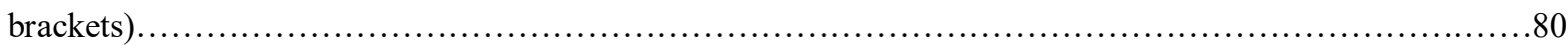

Table 4.1: Results of a three-factorial ANOVA with the effects of salt marsh zone, sampling season and treatment (control plot vs. experimental island) on $\delta^{18} \mathrm{O}$ values of water extracted from roots of saltmarsh plants.

Table 4.2: Results of a three-factorial ANOVA with the effects of salt marsh zone, sampling season and treatment (control plot vs. experimental islands) on the source of water uptake of salt marsh plants.

Table 4.3: Contribution of three soil layers to plant water uptake in the three salt marsh zones (Pio = pioneer zone, Low $=$ lower salt marsh, Upp = upper salt marsh) on Spiekeroog Island (Control plots) and on the experimental islands (plant species: Pio: Spartina anglica, Low: Atriplex portulacoides, Upp: Elytrigia atherica; on experimental islands Atriplex portulacoides in all three zones) at three sampling dates. Values were calculated by means of a Bayesian calibrated stable isotope mixing model (package 'simmr') based on measured water isotope data of soil and plants. Bold numbers are the major depth of water uptake. .102 
Table S4.1: Monthly precipitation during the year of sampling campaigns from September 2014 to August 2015. Annual precipitation from September 2014 to August 2015 was 706 mm.

Table S4.2 Mean difference between $\delta$-values of ${ }^{18} \mathrm{O}$ and ${ }^{2} \mathrm{H}$ measured by cavity ring-down spectroscopy (CRDS) and values measured by isotope ratio mass spectroscopy (IRMS) for pure water samples and water samples with potential organic contamination

Table A3.1: Water types and assigned $\delta^{18} \mathrm{O}$ and $\delta^{2} \mathrm{H}$-values provided by the IAEA within the Water Isotope Inter-Comparison (WICO) 2016. 145 


\section{ACKNOWLEDGEMENTS}

Completing this $\mathrm{PhD}$ thesis would have never been possible without the help and encouragement of so many people. I would like to thank everybody who supported me throughout my $\mathrm{PhD}$ studies in any way, with special thanks to

Prof. Dr. Christoph Leuschner, my first referee and supervising professor, for offering me the opportunity to be part of this interesting research project and to perform this $\mathrm{PhD}$ thesis in his research group, and for guiding me throughout my $\mathrm{PhD}$ studies.

Prof. Dr. Alexander Knohl and Prof. Dr. Gerhard Zotz for co-supervising this thesis with numerous valuable advices, discussions and comments on the planning of my experiments and on my manuscripts.

Prof. Dr. Hermann Behling, Prof. Dr. Dirk Hölscher and Prof. Dr. Holger Kreft, for being members oft the thesis committee.

Dr. Dietrich Hertel for always being there when there were questions and problems to be solved. Thank you for the scientific support and motivation!

Dr. Heinz Coners for solving all technical problems and always taking time to help. He especially spent many hours and days patiently helping me to set up the extraction line and to get the Picarro instrument running.

Dr. Thorsten Balke for the great competent support during the planning and performance of the greenhouse experiment, and the writing of the manuscript.

The "Niedersächsisches Vorab der Volkswagen-Stiftung" and the Ministry for Science and Culture of Lower Saxony, for financial support of the BEFmate project. Thanks also to the project coordination in Göttingen and Oldenburg.

The administration of the Lower Saxony Wadden Sea National Park for giving us permission and access to the field site on Spiekeroog Island, and the team of the research center Wittbülten on Spiekeroog Island for logistic support during our field campaigns.

Dr. Martin Stock and the administration of the Schleswig-Holstein Wadden Sea National Park for allowing access to the field sampling sites in Westerhever, for giving an on-site introduction, and providing various data. Thank you also to the teams of volunteers at the lighthouse in Westerhever, for providing uncomplicated accommodation and interesting conversations during my sampling campaigns in Westerhever. 
The ICBM workshop staff, especially Helmo Nikolai and Gerrit Behrens, for their invaluable practical support during set up of the field experiment on Spiekeroog and during set up of the greenhouse experiment at ICBM Terramare, Wilhelmshaven.

The student assistants, Robert Fischer, Mona Kiepert, Till Montag and Marlena Winter for their reliable and patient aid during performance of the greenhouse experiment and the sorting of fine root samples.

My colleagues from the BEFmate project who became great friends during the project phase. Setting up the experimental islands and study plots and carrying out sampling campaigns were intense and sometimes challenging phases of field work which would not have been as fun without you. Thanks to my fellow PhD students Hagen Andert, Niklas Buhk, Thomas Dinter, Simone Hanekamp, Gesine Lange, Jennifer Schmitt, and to Dr. Thorsten Balke, Dr. Kertu Lõhmus, Daniela Meier and Dr. Kristin Thomsen for the good cooperation! Special thanks to Kristin Thomsen for the great mental support and motivation during all the time and to Jörn Thomsen for proof-reading of the introduction and discussion of this thesis!

My colleagues from the Department of Plant Ecology in Göttingen for the wonderful working atmosphere. It was a pleasure working in this department and getting to know so many nice people who became good friends during the past years. Natalia, you are the best office-mate ever! Thanks also to the technical assistants for their support in laboratory works. Special thanks to Roman Link, for giving me great initial support in working with $\mathrm{R}$ and for very helpful discussions about statistics. My whole family, for all their support and encouragement during my studies and for always being there! 


\title{
CURRICULUM VITAE
}

\author{
Regine Redelstein \\ Born on 23 April 1988 in Augsburg, Germany
}

\section{EDUCATION}

2014-2018

University of Göttingen

$\mathrm{PhD}$ student in the $\mathrm{PhD}$ program 'Biodiversity and Ecology'

Department of Plant Ecology and Ecosystems Research

2010-2013

RWTH Aachen University

Master of Science in Biology

$2007-2010$

RWTH Aachen University

Bachelor of Science in Biology

2007

St. Ursula Gymnasium Aachen

High school graduation

\section{WORK EXPERIENCE}

2013-2014

2010-2013

2010
Graduate assistant at the Research Institute for Ecosystem Analysis and Assessment (gaiac), RWTH Aachen University

Student assistant at the Department for Ecosystems Analysis, RWTH Aachen University

Undergraduate Research Opportunity Program at the University of Saskatchewan, Saskatoon, Canada 


\section{Publications Associated With The Present Study}

Dinter T, Redelstein R, Leuschner C, Kuzykov Y Nutrient and fine root patterns during soil development within saltmarsh ecosystems and on artificial islands. In preparation.

Orlowski N, Breuer L, Angeli N, Boeckx P, Brumbt C, Cook CS, Dubbert M, Dyckmans J, Gallagher B, Gralher B, Herbstritt B, Hervé-Fernández P, Hissler C, Koeniger P, Legout A, Macdonald CJ, Oyarzún C, Redelstein R, Seidler C, Siegwolf R, Stumpp C, Thomsen S, Weiler M, Werner C, McDonnell JJ (2018) Inter-laboratory comparison of cryogenic water extraction systems for stable isotope analysis of soil water. Hydrology and Earth System Sciences 22:3619-3637. doi:10.5194/hess-22-3619-2018.

Redelstein R, Coners H, Knohl A, Leuschner C (2018) Water sources of plant uptake along a salt marsh flooding gradient. Oecologia 188:607-622. doi:10.1007/s00442-018-4229-9.

Redelstein R, Dinter T, Hertel D, Leuschner C (2018) Effects of Inundation, Nutrient Availability and Plant Species Diversity on Fine Root Mass and Morphology Across a Saltmarsh Flooding Gradient. Frontiers in Plant Science 9:98. doi:10.3389/fpls.2018.00098.

Redelstein R, Zotz G, Balke T (2018) Seedling stability in waterlogged sediments. An experiment with saltmarsh plants. Marine Ecology Progress Series 590:95-108. doi:10.3354/meps12463.

\section{PRESENTATIONS}

Redelstein R, Hertel D, Balke T, Kleyer M, Leuschner C Belowground plant biomass along a salt marsh flooding gradient. $45^{\text {th }}$ Annual Meeting of the Ecological Society of Germany (GfÖ). Poster. August 31-September 4, 2015, Göttingen, Germany.

Redelstein R, Hertel D, Balke T, Kleyer M, Leuschner C Belowground plant biomass along a salt marsh flooding gradient. $23^{\text {rd }}$ Coastal Ecology Workshop. November 1-5, 2015, Westerhever, Germany.

Redelstein R, Zotz G, Balke $\mathrm{T}$ Morphological traits of salt marsh seedlings: What determines stability against physical disturbances? $101^{\text {st }}$ Annual Meeting of the Ecological Society of America (ESA). August 7-12, 2016, Fort Lauderdale, Florida, USA. 


\section{DECLARATION OF ORIGINALITY AND CERTIFICATE OF OWNERSHIP}

I, Regine Redelstein, hereby declare that I am the author of the present dissertation entitled 'Root system structure and functions across coastal saltmarsh gradients'. All references and data sources that were used in the dissertation have been appropriately acknowledged and cited. I furthermore declare that this work has not been submitted elsewhere in any form as part of another dissertation procedure.

Göttingen, December 20, 2017

(Regine Redelstein) 
